RODRIGO AFFONSO DE ALBUQUERQUE NÓBREGA

DETECÇÃO DA MALHA VIÁRIA NA PERIFERIA URBANA DE SÃO PAULO UTILIZANDO IMAGENS DE ALTA RESOLUÇÃO ESPACIAL E CLASSIFICAÇÃO ORIENTADA A OBJETOS 
RODRIGO AFFONSO DE ALBUQUERQUE NÓBREGA

\section{DETECÇÃO DA MALHA VIÁRIA NA PERIFERIA URBANA DE SÃO PAULO UTILIZANDO IMAGENS DE ALTA RESOLUÇÃO ESPACIAL E CLASSIFICAÇÃO ORIENTADA A OBJETOS}

Tese apresentada à Escola

Politécnica da Universidade de São

Paulo para obtenção do título de

Doutor em Engenharia

Área de Concentração:

Engenharia de Transportes

Orientador:

Prof. Dr. José Alberto Quintanilha 
Este exemplar foi revisado e alterado em relação à versão original, sob responsabilidade única do autor e com a anuência de seu orientador.

São Paulo, de maio de 2007.

Assinatura do autor

Assinatura do orientador

FICHA CATALOGRÁFICA

Nóbrega, Rodrigo Affonso de Albuquerque

Detecção da malha viária na periferia urbana de São Paulo utilizando imagens orbitais de alta resolução espacial e classificação orientada a objetos / R.A. de A. Nóbrega. - ed.rev. - São Paulo, 2007.

$166 \mathrm{p}$.

Tese (Doutorado) - Escola Politécnica da Universidade de São Paulo. Departamento de Engenharia de Transportes.

1.Sensoriamento remoto 2.Planejamento de transportes 3.Urbanização 4.Imageamento de satélite 5.Classificação I.Universidade de São Paulo. Escola Politécnica. Departamento de Engenharia de Transportes II.t. 
Dedico este trabalho ao meu filho, ainda no ventre de meu amor. 
... que os frutos possam ser colhidos, servir de alimento e de semente para gerações futuras ... 


\section{AGRADECIMENTOS}

Meus sinceros agradecimentos ...

Ao amigo José Alberto Quintanilha, pelo equilíbrio, pela tranqüilidade e pela confiança depositada em mim, durante todo o período em que o trabalho fora desenvolvido.

Ao Dr. Charles G. O'Hara, por abraçar a idéia e por todo o apoio oferecido. I'll never forget the help you did. I appreciate that.

Aos amigos do Laboratório de Geoprocessamento. Trabalhar ao lado de vocês foi mais que um prazer, foi uma satisfação, sempre!!

Aos amigos Gunnar Olson, Sung-Jun Kim e Veeraraghavan Vijayaraj, pelo acolhimento e parceria nos momentos mais difíceis. Thank you guys so much!

Ao grupo de trabalho do Laboratório de Sistemas de Suporte a Decisões do Departamento de Engenharia Hidráulica e Sanitária da Escola Politécnica da Universidade de São Paulo, pelos dados oferecidos.

Ao Instituto Geológico da Secretaria do Meio Ambiente do Estado de São Paulo, pelas imagens IKONOS gentilmente cedidas.

Ao GeoResources Institute da Mississippi State University.

Ao Conselho Nacional de Desenvolvimento Cientifico e Tecnológico - CNPq, pelo apoio oferecido.

À Coordenação de Aperfeiçoamento de Pessoal de Nível Superior - CAPES, pelo apoio oferecido quanto ao estágio no exterior.

Aos meus pais e avós, que me ensinaram a sonhar e que hoje vivem meu sonho.

À minha esposa Liria Akie Okai, pela paciência, compreensão e parceria em todos os momentos. Nosso amor foi maior que o tempo e a distância. 


\section{SUMÁRIO}

1 INTRODUÇÃO

1.1 ASPECTOS GERAIS …............................................................................................................... 19

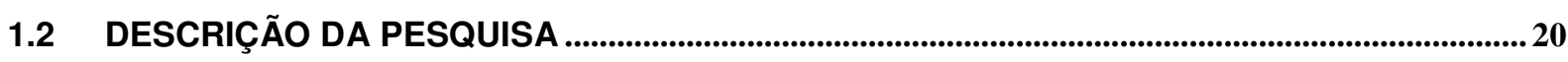

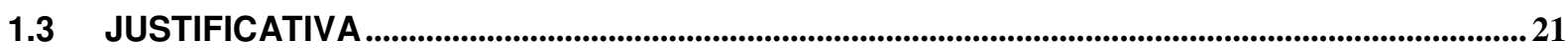

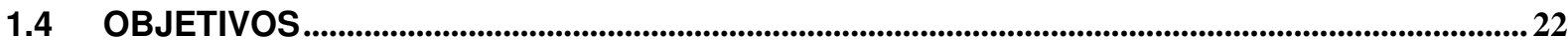

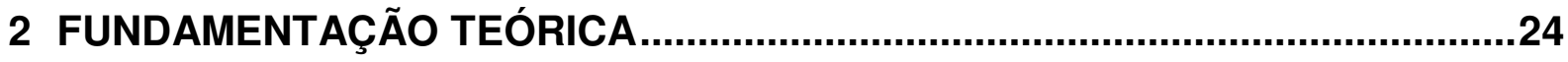

2.1 PRINCÍPIOS E CONCEITOS EM SENSORIAMENTO REMOTO ….............................................24

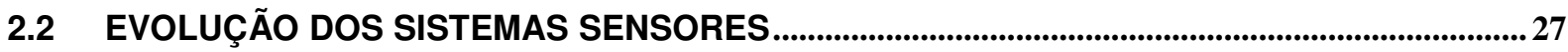

2.2.1 O aumento da resolução espacial das imagens orbitais..............................27

2.2.2 O aumento do nível de quantização nos novos sensores ...........................30

2.3 EXPLORAÇÃO DA IMAGEM DIGITAL EM SENSORIAMENTO REMOTO..................................32

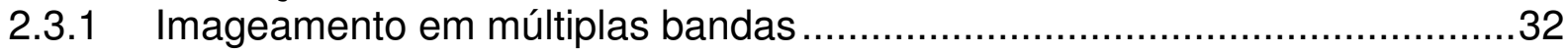

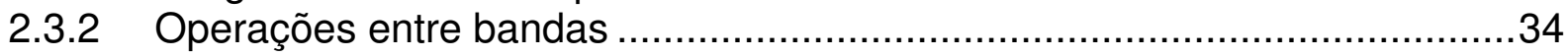

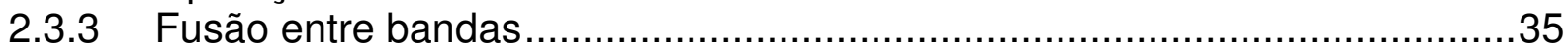

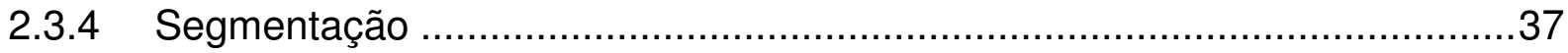

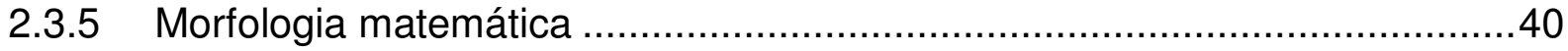

2.4 ESTADO DA ARTE DA EXTRAÇÃO DE INFORMAÇÕES EM SENSORIAMENTO REMOTO43

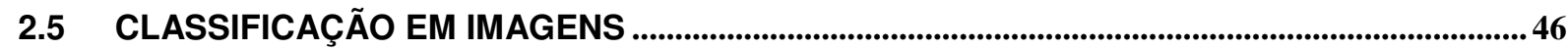

2.6 A PROBLEMÁTICA DOS CLASSIFICADORES TRADICIONAIS PARA IMAGENS DE ALTA RESOLUÇÃO ESPACIAL .....................................................................................................50

2.7 CONSIDERAÇÕES SOBRE CLASSIFICAÇÃO FUZZY............................................................52

2.8 CLASSIFICAÇÃO DE IMAGENS BASEADA EM OBJETOS.....................................................57

2.9 DESCRITORES UTILIZADOS NA CLASSIFICAÇÃO BASEADA EM OBJETOS DESTA

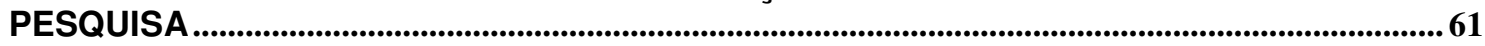

2.10 CONSIDERAÇÕES SOBRE ESTIMAÇÃO DA ACURÁCIA DA EXTRAÇÃO DE INFORMAÇÕES EM SENSORIAMENTO REMOTO .................................................................................63

2.11 ANÁLISE DE CORRESPONDÊNCIA LINEAR ....................................................................................64

3 RECURSOS EMPREGADOS NA PESQUISA ...............................................68

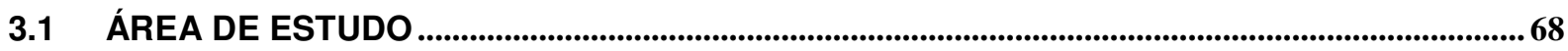

3.2 PROJETO CABUÇU DE BAIXO ........................................................................................................70 
3.3 IMAGENS IKONOS II... 73

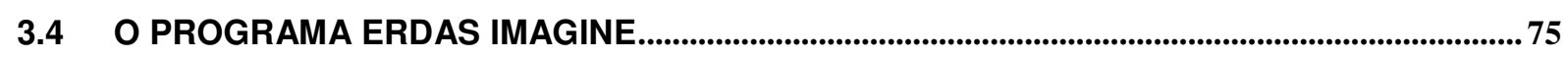

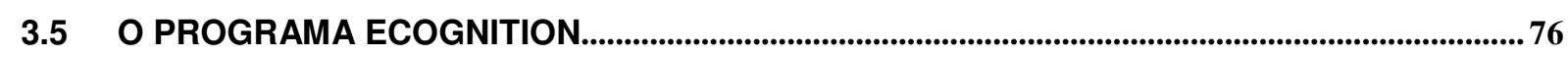

3.6 LINEAR FEATURE COMPATIVE ANALYSIS TOOLKIT-LCAT.....................................................77

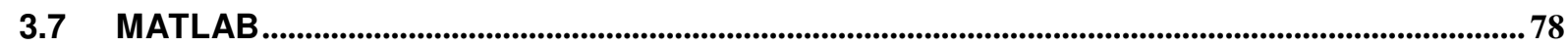

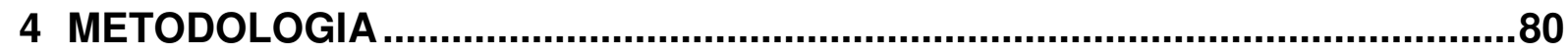

4.1 COMPATIBILIZAÇÃO DOS DADOS

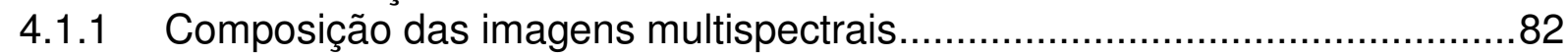

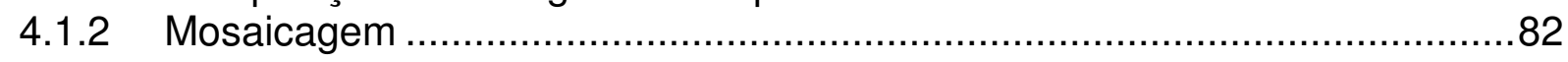

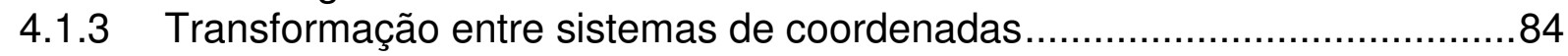

4.2 CRIAÇÃO DOS OBJETOS POR SEGMENTAÇÃO ................................................................................8 84

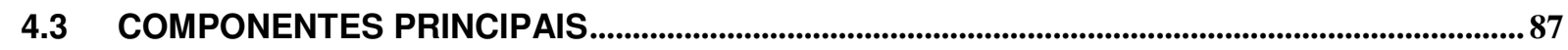

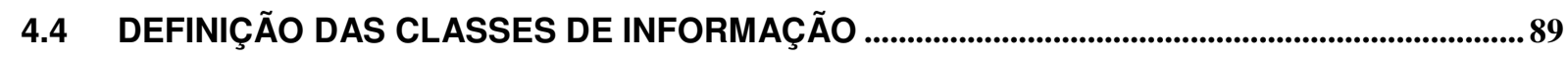

4.5 DETECÇÃO DE ÁREAS DE SOLO EXPOSTO ........................................................................91

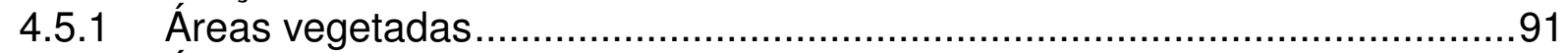

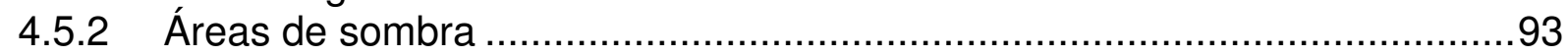

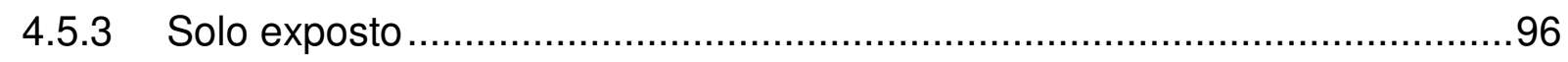

4.6 DETECÇÃO DE ÁREAS IMPERMEABILIZADAS ..........................................................................104

4.7 DETECÇÃO DO SISTEMA VIÁRIO .........................................................................................................107

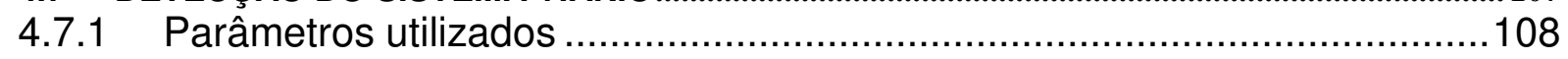

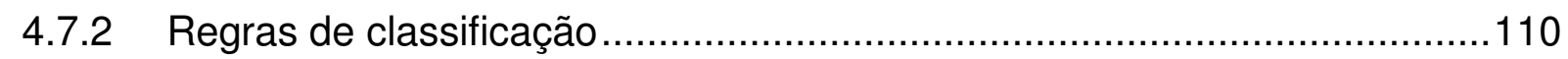

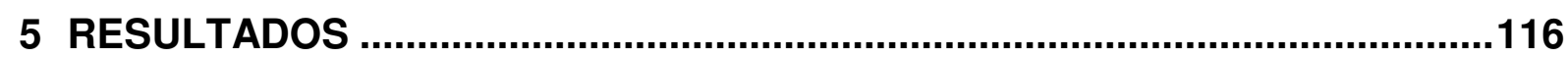

5.1 ANÁLISE VISUAL DA MALHA VIÁRIA DETECTADA ..................................................................116

5.2 EXATIDÃO DA CLASSIFICAÇÃO

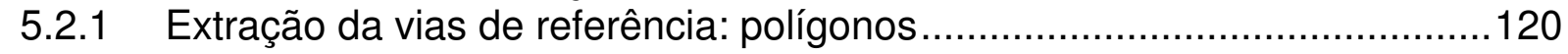

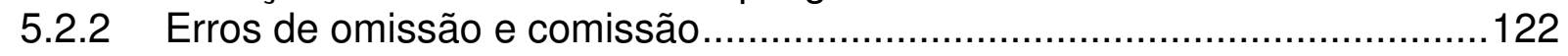

5.3 AVALIAÇÃO DA CORRESPONDÊNCIA LINEAR DA MALHA VIÁRIA DETECTADA............130

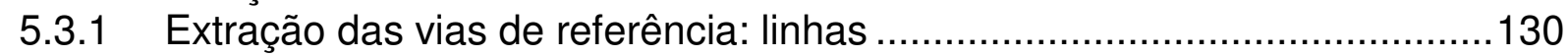

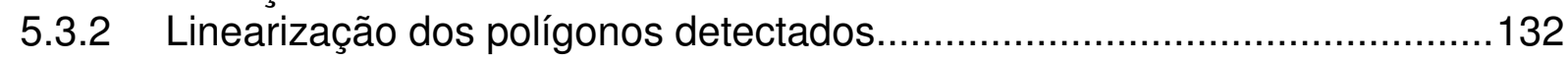

5.3.3 Análise da correspondência linear ............................................. 136

6 DISCUSSÃO

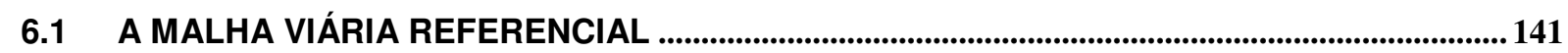

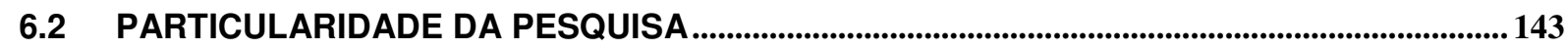




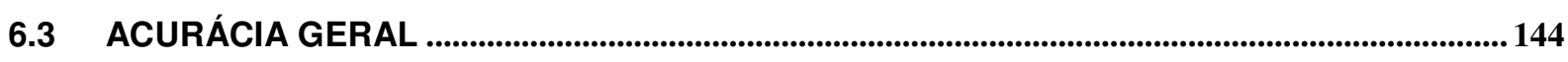

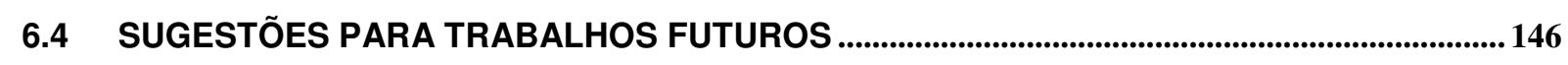

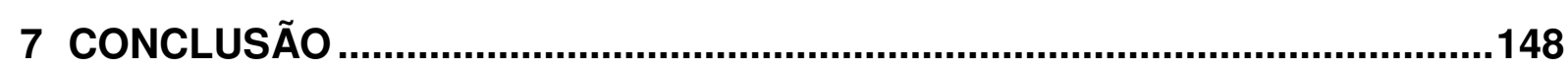

REFERÊNCIAS BIBLIOGRÁFICAS ............................................................150

REFERÊNCIAS CONSULTADAS ...................................................................162 


\section{LISTA DE ILUSTRAÇÕES}

Figura 1 - Padrões de curvas espectrais de elementos comuns encontrados no ambiente urbano. As respostas espectrais foram obtidas em um ambiente controlado de laboratório, utilizando um espectroradiômetro modelo GER 1500, adaptado de Jensen (2000). 26

Figura 2 - Imagem IKONOS ilustrando a aparente perda de detalhamento das feições em uma região coberta por sombra e a posterior restauração das informações devido à quantização da imagem em 11 bits. Adaptado de Koyuncu (2002).

Figura 3 - Fusão das bandas multispectrais pancromática do satélite IKONOS, com quatro metros e um metro, respectivamente (LILLESAND, KIEFFER e CHIPMAN, 2004).

Figura 4 -llustração da vizinhança de conectividade 4 (esquerda) e da vizinhança de conectividade 8 (direita). Adaptado de Vincent (1993).

Figura 5 - Visão geral das operações de morfologia matemática binária.

Figura 6 - llustração do espaço bidimensiional de atributos com agrupamentos de pixels com padrões espectrais semelhantes. Adaptado de Lillesand, Kiefer e Chipman (2004).

Figura 7 - Estratégias de classificação. Em ordem: Distância mínima da média, paralelepípedo e máxima verossimilhança. Adaptado de Lillesand, Kieffer e Chipman (2004).

Figura 8 - Partição do espaço em função da classe atribuída à temperatura utilizando funções fuzzy de pertinência. Adaptado de Tso e Mather (2001).

Figura 9 - Funções de pertinência comuns em sistemas fuzzy: (a) monotônica, (b) triangular, (c) trapezoidal e (d) em forma de sino. (TSO e MATHER, 2001).

Figura 10 - Arquitetura básica do sistema fuzzy. Adaptado de Tso e Mather (2001).

Figura 11- Fluxograma dos procedimentos adotados na classificação orientada a objetos.

Figura 12 - Princípio da análise de correspondência linear. Acima o casamento com a linha de referência (zona de referência) e abaixo o casamento com a linha extraída (zona da extração). Adaptado de Wiedemann (2003).

Figura 13 - Vista geral da região norte da cidade de São Paulo, ilustrando a área de estudo e sua topografia acidentada. 
Figura 14 - Vista panorâmica da ocupação irregular das edificações e do sistema viário em uma região de limite entre a mancha urbana e a área florestal da Serra da Cantareira.

Figura 15 - Plano de informação contendo a base de logradouros (BARROS, 2004)

Figura 16 - Articulação das ortofotos disponíveis.

Figura 17 - Imagem do satélite IKONOS II da área do projeto decomposta pelas quatro bandas espectrais que a compõem. De baixo para cima: azul, verde, vermelho e infravermelho próximo. .73

Figura 18 - Cobertura das imagens IKONOS II do Instituto Geológico da Secretaria do Meio Ambiente do Estado de São Paulo. FUNCATE (2004)..............................74

Figura 19 - Fluxograma das etapas proposto na metodologia. .80

Figura 20 - Articulação das folhas disponíveis sobre a Região Metropolitana de São Paulo e as respectivas informações de órbita e data de captura das imagens IKONOS II. Em destaque, as folhas cujas imagens foram utilizadas nesse trabalho.

Figura 21 - llustração do mosaico das duas imagens multispectrais geradas, recobrindo a área selecionada para o estudo, representada pelo retângulo preenchido em amarelo

Figura 22 - Tela capturada do programa eCognition contendo os parâmetros e os dados utilizados na segmentação.

Figura 23 - Imagem parcial da área de estudo (acima) e a respectivo resultado da segmentação. Os menores elementos gerados refletem a largura das vias mais periféricas.

Figura 24 - llustração das 4 bandas espectrais das imagens IKONOS utilizadas e as respectivas componentes principais computadas e utilizadas no desenvolvimento do trabalho. 88

Figura 25 - Classes auxiliares e classes principais utilizadas na metodologia do presente trabalho. .........................................................................................

Figura 26 - Resultado da classificação das áreas vegetadas...................................92

Figura 27 - Gráfico da função de pertinência modelada para o índice indicador de sombra.

Figura 28 - Resultado da classificação das áreas de sombra. .95 
Figura 29 - Gráfico da função de pertinência modelada para a classe SOLO

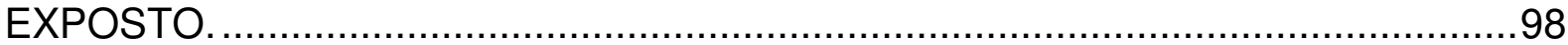

Figura 30 - Resultado da ação do índice indicador de solo exposto. Áreas claras representam as respectivas áreas de solo exposto e telhados cerâmicos.

Figura 31 - Telhados cerâmicos detectados erroneamente como áreas de solo exposto, passíveis de serem detectados ao se considerar características geométricas e topológicas nas estratégias de classificação. 100

Figura 32 - Ilustração do índice de ajuste retangular do eCognition. 101

Figura 33 - Função de pertinência modelada para área para a filtragem dos objetos TELHADO CERÂMICO pré-classificados como SOLO EXPOSTO. 102

Figura 34 - Função de pertinência modelada para o coeficiente de ajuste retangular para a filtragem dos objetos TELHADO CERÂMICO pré-classificados como SOLO EXPOSTO. 102

Figura 35 - Função de pertinência modelada para objetos da classe SOLO EXPOSTO vizinhos de objetos da classe SOMBRA, visando filtragem dos mesmos para reclassificação como sendo TELHADO CERÂMICO. 103

Figura 36 - Resultado da classificação das áreas de solo exposto, base para a detecção das vias não pavimentadas. 104

Figura 37 - Gráfico da função de pertinência atribuída a classe ÁREA IMPERMEABILIZADA. 105

Figura 38 - Segunda componente principal (esquerda) utilizada na identificação de áreas com superfícies impermeabilizadas (direita). (NOBREGA et al, 2006)..........106

Figura 39 - Planos de informação usados na detecção e classificação das vias. ...108

Figura 40 - Árvore de processos do eCognition indicando seqüência de passos da classificação.

Figura 41 - Estratégia de detecção da malha viária definida pelas classes e respectivas regras de classificação impostas às mesmas.

Figura 42 - Visualização tridimensional da imagem IKONOS e da malha viária resultante da classificação orientada a objeta sobreposto sobre a mesma.

Figura 43 - Cobertura da área de estudo pelas ortofotos do Projeto Cabuçu de Baixo e as respectivas vias de referência digitalizadas em tela. 121

Figura 44 - Vetorização dos polígonos referentes às vias sobre as ortofotos. 122 
Figura 45 - Polígonos das vias extraídas como referência sobrepostos na imagem IKONOS.

Figura 46 - Polígonos das vias classificadas sobrepostos na imagem IKONOS.....123

Figura 47 - llustração dos planos de informação utilizados na análise.

Figura 48 - Classificação correta das vias.

Figura 49 - Vias não classificadas.

Figura 50 - Feições urbanas classificadas erroneamente como vias.

Figura 51 - Vetorização dos eixos das vias sobre as ortofotos.

Figura 52 - Detalhe da vetorização dos eixos das vias sobre as ortofotos.

Figura 53 - Linhas resultantes (em amarelo) do afinamento dos polígonos (em preto) resultante do processo de classificação das vias.

Figura 54 - Visualização tridimensional das linhas de referência e das linhas resultantes da classificação sobre a imagem IKONOS.

Figura 55 - Visão geral do programa L-CAT utilizado na análise linear comparativa.

Figura 56 - Tela capturada do programa L-CAT ilustrando as linhas de referência (vermelho) e seus respectivos buffers, bem como as linhas extraídas das áreas classificadas (ciano). 


\section{LISTA DE TABELAS}

Tabela 1 - Quadro comparativo das resoluções espacial e temporal dos satélites operantes voltados ao imageamento em alta resolução espacial. .29

Tabela 2 - Síntese de alguns dos principais operadores de morfologia matemática utilizados nesse trabalho. Adaptado de Gonzales e Woods (1993).

Tabela 3 - Arquivos correspondentes às bandas das imagens IKONOS disponibilizadas e a respectiva ordem de empilhamento das imagens multispectrais.

Tabela 4 - Sequência dos passos mais relevantes e seus respectivos resultados, que descrevem as principais etapas na detecção da malha viária apresentada nesse trabalho.

Tabela 5 - Planos de informação secundários utilizados na análise da exatidão e as operações utilizadas na criação dos mesmos a partir dos planos de informação básicos

Tabela 6 - Planos de informação e suas respectivas áreas utilizados na análise da exatidão 128

Tabela 7 - Seqüência de comandos do programa Matlab utilizados no afinamento das áreas classificadas da malha viária.

Tabela 8 - Resultados do programa L-CAT abrangendo resoluções entre 1 e 4 pixels e buffers entre 2 e 6 metros 138

Tabela 9 - Interpolação da precisão para a zona de análise com largura de 9 metros. 


\section{RESUMO}

O crescimento descontrolado ocorrido nas atuais metrópoles de países em desenvolvimento requer intensos mapeamentos para a atualização da base de dados geográfica. O intenso processo de urbanização vivido na cidade de São Paulo desde os anos 70 ilustra bem esse cenário. Apesar de existirem levantamentos aéreos e, mais recentemente, imagens de satélite com alta resolução espacial, a necessidade de informações geográficas precisas, rápidas e menos onerosas é, mais do que nunca, um fato. Nesse sentido, a classificação automatizada de imagens de alta resolução espacial tem demonstrado resultados insatisfatórios ao utilizar classificadores pixel a pixel, em especial para áreas urbanas. O crescente sucesso da classificação de imagens baseada em objetos tem estimulado pesquisadores a criar novos meios de superar a limitação das tradicionais técnicas de classificação de imagens. A idéia central da classificação de imagens orientada a objetos é extrair objetos primitivos a partir das imagens e utilizar suas informações para a composição de regras e estratégias a serem aplicadas no processo classificatório. Além da análise espectral, a classificação de imagens baseada em objetos permite envolver análises geométricas e contextuais. Este trabalho reporta o uso da classificação baseada em objetos para detecção da malha viária, aplicado na periferia urbana da cidade de São Paulo. Áreas de ocupação irregular compõem a maior parte da área selecionada para o estudo, sendo que a malha viária reflete bem o padrão de ocupação não planejada dessa região. As ruas são em geral geometricamente irregulares e com diferentes tipos de pavimentação. Detectar a malha viária com base nessas características foi o desafio maior deste trabalho, que teve, como hipótese, a viabilidade do emprego da classificação orientada a objetos para essa finalidade. A metodologia apresentada utiliza uma imagem multiespectral do satélite IKONOS II. Como primeiros passos, processou-se a segmentação e calcularam-se as componentes principais. Classes auxiliares como áreas impermeabilizadas e áreas de solo exposto foram computadas utilizando funções apropriadas. Em suma, a partir das informações geométricas dos objetos, como largura, comprimento, coeficiente de assimetria, área, entre outros, alguns objetos foram selecionados como representantes da malha viária, e então 
analisados perante a informação contextual, para que fossem classificados como vias pavimentadas e vias não pavimentadas. Os resultados foram analisados mediante três diferentes métodos: 1) inspeção visual, na qual foi analisada qualitativamente a aderência entre as vias extraídas e as vias reais; 2) acurácia da classificação, através de comparações entre a malha viária detectada e a de referência, que forneceu parâmetros estatísticos de qualidade da classificação, como os erros de comissão e omissão ; 3) análise linear comparativa, a qual forneceu parâmetros como integridade (ou completeza) e precisão da malha viária detectada utilizando linhas referenciais e linhas extraídas dos polígonos das vias detectadas, obtidos por morfologia matemática. Considerando o alto grau de heterogeneidade das feições presentes na área de estudo, a acurácia geral alcançada foi boa. Embora a metodologia não tenha produzido um mapa viário, no sentido próprio da palavra, o uso combinado de imagens multispectrais de alta resolução espacial e da classificação baseada em objetos mostrou que a metodologia pode ser utilizada para minerar dados relativos a malha viária e produzir informações significantes para auxiliar a tomada de decisões. 


\begin{abstract}
Uncontrolled sprawl occurring in large cities of developing countries requires intensive mapping efforts to update geodatabases. The intense urbanization process experienced since the 70's in Sao Paulo city illustrates very well the reported scenario. Despite aerial data and, more recent, high spatial resolution satellite data which have been employed as basis for mapping, the need for precise, faster and cheaper mapping efforts is real. In this sense, automated classification of high resolution imagery has demonstrated unsatisfactory results when traditional per-pixel classifiers are used, especially for urban areas. The increasing success of objectbased classification has stimulated researchers to create new methodologies to overcome this shortcoming of traditional approaches. The object-based image classification's idea is extract object-primitives from images and then use their information to compose rules and strategies to be applied on the classification process. Beyond the spectral analysis, geometric, and contextual analysis are also addressed on object-based classification. This work reports the use of object-based image classification applied on road detection over the suburban area of Sao Paulo city. Informal settlements compose the most part of the study area and the transportation network reflects the unplanned occupation. Roads are geometrically irregular and with different kind of pavements. Detecting roads based on these characteristics was the biggest challenge faced here, and this work hypothesizes object-based classification can be used to. The methodology presented employs an IKONOS II data. At first, principal components and segmentation were computed and then auxiliary data for impervious surface and bare soil areas were previously calculated from customized features. In short, based on geometric information as width, length, asymmetry, area, and more, objects were elected as road and then analyzed through contextual information as paved road or unpaved road. Results were analyzed under three different ways: 1) visual inspection, where the adherence between extracted road and real ones provided a good indicator for qualitative analysis ; 2) classification accuracy, by comparing detected road areas and referential ones, which provided statistical parameters for quality as omission and commission error ; 3) linear comparative analysis, which provided parameters as
\end{abstract}


correctness and completeness using referential lines and lines arose from extracted areas based on mathematical morphology tools. Regarding the high degree of heterogeneity of features present on study area, the overall accuracy reached is good. Despite the methodology did not produce a road map, the results shown the combined use of high resolution multi-spectral imagery and object-based classification can effectively mine road features, producing significant information to support decision makers. 


\section{INTRODUÇÃO}

\subsection{ASPECTOS GERAIS}

O crescimento ocorrido das grandes metrópoles nas últimas décadas foi regido por questões sócio-econômicas provocadas pela mudança de paradigmas no cenário econômico nacional, com o mercado industrial absorvendo grande parte da mão de obra, até então agrícola. Segundo Santos (2001), nos últimos quarenta anos, enquanto o aumento da população brasileira foi de três vezes, a população urbana brasileira sofreu um aumento de sete vezes e meia.

Em meio a esse processo, as cidades não dispuseram de meios para gerenciar a demanda, em conseqüência do aumento da população, dando origem a processos desordenados de ocupação e uso do solo (JANNUZZI e JANNUZZI, 2002). Tais processos passaram a ocorrer nos grandes centros urbanos, com maior intensidade, nas últimas duas décadas, como por exemplo, as perdas provocadas pelas enchentes em áreas atualmente ocupadas, as ocupações irregulares em áreas de manancial, ou mesmo o caótico trânsito urbano, provocado pelo desequilíbrio entre o sistema de transportes e o crescente volume de usuários.

Frente a essa realidade, diversas pesquisas vêm sendo incentivadas, não somente para avaliar os impactos gerados, como também para entender e organizar o ambiente urbano contemporâneo e futuro. A demanda por informações espaciais precisas e atualizadas surge então como uma premissa para o planejamento e gestão das cidades. Nesse sentido, destaca-se o emprego do sensoriamento remoto como ferramenta geradora de informações para o monitoramento, análise e mapeamento ambiental. Seu uso vem sendo cada fez mais freqüente e os resultados cada vez mais promissores. 


\subsection{DESCRIÇÃO DA PESQUISA}

O presente trabalho surge como uma ferramenta de apoio para analisar parte das mudanças ocorridas no ambiente urbano das grandes cidades brasileiras. Embora as conseqüências das transformações do cenário urbano englobem as características ambientais, físicas, econômicas e sociais, esta pesquisa está restrita ao âmbito das transformações físicas, e tem como foco a detecção da malha viária na periferia da cidade de São Paulo, uma vez que o sistema, o surgimento e as transformações das vias refletem diretamente o crescimento populacional e a expansão da mancha urbana sobre áreas rurais e florestais.

Embora em constante evolução, os recursos computacionais e de sensoriamento remoto nem sempre são empregados de forma eficiente. Imagens de satélite de alta resolução espacial têm sido utilizadas como pano de fundo, provendo suporte para análises visuais e extrações manuais de informação. Neste trabalho são utilizadas imagens de satélite e aplicativos de classificação dessas imagens, como forma de subsidiar a deteç̧ão automatizada das vias nas regiões periféricas dos grandes centros urbanos, cujas principais características estão representadas na área de estudo selecionada.

Ainda, são relatados no trabalho alguns dos principais problemas decorrentes do surgimento das imagens de alta resolução espacial, em especial para a classificação automatizada. Seguindo uma tendência atual, é descrita a técnica de classificação baseada em objetos, como alternativa para a lacuna deixada pelo emprego de classificadores tradicionais nesse tipo de imagem. Em sendo uma tecnologia recente, a classificação de imagens baseada em objetos encontra-se em fase de expansão de seus horizontes, para a qual novas formas de processamento e regras de classificação vêm sendo pesquisadas, a fim de se obterem resultados cada vez mais confiáveis.

A metodologia apresentada tem como base a segmentação da imagem do satélite IKONOS II, sendo os segmentos então denominados objetos. A classificação baseada em objetos possibilita a criação de um conjunto de regras que transcendem o limiar da análise espectral. Em outras palavras, informações 
associadas à forma, área, e topologia dos objetos, por exemplo, podem ser inseridas no conjunto de regras para a classificação. Nesse sentido, pelo caráter particular de cada localidade, a definição e a forma de uso dessas informações vêm sendo objeto de estudo em diversos centros de pesquisa envolvidos com aplicações urbanas de sensoriamento remoto.

Visando atender os objetivos propostos e cobrindo os principais temas envolvidos na pesquisa, o presente trabalho aborda, no capítulo 2, uma revisão sobre os conceitos básicos de sensoriamento remoto e processamento digital de imagens considerados neste trabalho. É introduzida também, nesse capítulo, a extração de informações das imagens digitais, seguindo uma estrutura fundamentada em conceitos clássicos de extração de informações, lógica fuzzy e classificação de imagens por objetos, bem como algumas considerações sobre análise da acurácia em classificação de imagens e análise linear comparativa. $O$ capítulo 3 apresenta os recursos empregados no trabalho, incluindo a área de estudo, as bases de informação, as ferramentas utilizadas e a análise proposta para a malha viária detectada. A descrição detalhada da metodologia, envolvendo a criação dos objetos e das regras de classificação baseadas em informações extraídas dos mesmos, é apresentada no capítulo 4. No capítulo 5 são apresentados os resultados, envolvendo análises de erros de omissão e comissão dos polígonos classificados, bem como a análise linear comparativa da malha viária. As discussões são apresentadas no capítulo 6 e a conclusão no capítulo 7. Por fim, são apresentadas as referências bibliográficas.

\subsection{JUSTIFICATIVA}

É fato que as imagens orbitais de alta resolução espacial têm tido uma procura crescente desde o lançamento do satélite IKONOS II em 1999, em parte, por se tratar de um programa espacial de domínio civil. Também é fato que o potencial sugerido para o emprego dessas imagens vai além da simples representação visual da área de interesse, como "pano de fundo" para a ilustração de projetos. Todavia, a 
massificação de seu uso como uma fonte de informações voltada à necessidade de mapeamento e monitoramento da superfície terrestre, similar ao que já ocorre com as tradicionais imagens dos satélites LANDSAT e SPOT, ainda é alvo de discussão.

O estágio tecnológico atual aponta para $\mathrm{O}$ uso de técnicas de classificação baseada em objetos, as quais levam em consideração regras de decisão constituídas por informações inseridas por analistas, sobre seu conhecimento quanto às feições na superfície imageada. Resultados significativos vêm sendo obtidos na classificação de uso e ocupação do solo urbano, em grande parte para cidades européias e norte americanas.

Nesse sentido, o presente trabalho busca integrar a classificação de imagens de alta resolução às pesquisas em sensoriamento remoto no âmbito nacional. As características físicas, econômicas, ambientais e culturais do complexo ambiente urbano das grandes cidades deverão ser modeladas através de parâmetros locais, aplicando o conhecimento de pesquisadores brasileiros na avaliação das propriedades espectrais e espaciais dos objetos, bem como na composição das regras utilizadas na classificação. Como alvo para a pesquisa, foi proposta a detecção da malha viária suburbana, tomada a partir de uma área teste devidamente selecionada.

Propõe-se, além das análises das principais características descritoras das vias, o desenvolvimento de uma metodologia de extração e análise da malha viária detectada, passível de ser aplicada em áreas de ocupação similares. O presente trabalho pode ser definido como um dos passos iniciais na tentativa de automatizar o processo de mapeamento e monitoramento da malha viária urbana.

\subsection{OBJETIVOS}

A contribuição maior deste trabalho é dada pela elaboração de uma metodologia que utiliza regras de classificação baseadas em conhecimentos atribuídos aos objetos extraídos da imagem, por sua vez, característicos da ocupação do solo na periferia urbana da cidade de São Paulo. 
Em vista do crescimento da mancha urbana e, conseqüentemente, da criação e adaptação do sistema viário nessas novas áreas e, em função da disponibilidade das imagens de satélite de alta resolução, da decorrente problemática envolvendo o emprego de técnicas tradicionais de classificação dessas imagens e da possibilidade de empregar técnicas de classificação baseadas em objetos, o presente trabalho tem como objetivos:

- Analisar as características espectrais, geométricas, topológicas e contextuais das feições definidoras da malha viária em formação na periferia urbana;

- Definir e avaliar um conjunto de regras que serão utilizadas para o processo de classificação orientada a objetos;

- Analisar os resultados da malha viária detectada perante os dados reais;

- Propor uma metodologia de detecção e análise das vias, a partir de imagens orbitais de alta resolução espacial, que possa ser aplicada em outras periferias urbanas similares. 


\section{FUNDAMENTAÇÃO TEÓRICA}

\subsection{PRINCÍPIOS E CONCEITOS EM SENSORIAMENTO REMOTO}

Segundo Lillesand, Kieffer e Chipman (2004), sensoriamento remoto refere-se à ciência e à arte de obter informações de um objeto, área ou fenômeno, através de análises de dados adquiridos por dispositivos sem o contato sobre os objetos, área ou fenômeno sob investigação. Novo (1992) descreve que, não havendo o contato, a transferência dos dados para o dispositivo é feita através de energia. A definição de sensoriamento remoto é ampla, podendo envolver diferentes tipos de energia. No entanto, baseado em Lillesand, Kieffer e Chipman (2004), Novo (1992), e Moik (1980), a necessidade de focar o imageamento da superfície da Terra permite restringir seu conceito para a aquisição, processamento e análise das informações da superfície terrestre, através da interação entre a radiação eletromagnética e as substâncias componentes da superfície, obtidas remotamente por meio de plataformas orbitais e aerotransportadas.

Meneses (2001) menciona que a radiação eletromagnética mais familiar ao homem é a própria luz do Sol que ilumina a superfície terrestre, denominada luz visível. Porém, o Sol, como fonte de radiação eletromagnética, emite também radiação ultravioleta e infravermelha de ondas curtas. Também, a Terra, sendo uma fonte de radiação eletromagnética, é capaz de emitir radiação infravermelha, denominada termal. Radiações ultravioleta, visível, infravermelho próximo e termal e, ainda, microondas, são algumas das denominações, para fins práticos, atribuídas às divisões do espectro eletromagnético, e que podem ser identificadas pelos respectivos comprimentos de onda.

Todavia, a radiação eletromagnética emitida sofre interferências quando atravessa a atmosfera. Parte da radiação é difundida pelas partículas na atmosfera, pela interação das moléculas dos gases e de outras partículas de dimensões menores que o comprimento de onda da radiação incidente. Outra parte sofre uma efetiva perda de energia, ocorrida normalmente pela influência de vapor d'água, 
dióxido de carbono e de ozônio (LILLESAND, KIEFFER e CHIPMAN, 2004). Em vista dessas características de espalhamento e absorção da energia eletromagnética em diferentes comprimentos de onda, os sensores remotos são calibrados para operar nas chamadas janelas atmosféricas, que são as faixas espectrais livres, ou com menor interferência desses efeitos.

No entanto, fez-se necessário conhecer a forma com que os materiais, dispostos na superfície terrestre, interagem em diferentes comprimentos de onda da energia eletromagnética neles emitidos. Segundo Novo (1992), para que se possam extrair informações a partir de dados de sensoriamento remoto, é fundamental o conhecimento do comportamento espectral dos objetos da superfície terrestre e dos fatores que interferem neste comportamento. Ao selecionar, por exemplo, a melhor combinação de canais e filtros para uma composição colorida, deve-se conhecer o comportamento espectral do alvo de interesse. Sem esse conhecimento, corre-se o risco de desprezar faixas espectrais de grande importância na sua discriminação.

Desta forma, o comportamento espectral é dado pela variação do fator de reflectância em função do comprimento de onda empregado. Em outras palavras, ao se variar a radiação incidente sobre o objeto selecionado, são encontrados diferentes valores de reflectância. Em termos práticos, utilizam-se informações tabeladas ou gráficas, sendo essas, denominadas curvas ou assinaturas espectrais. Moik (1980) menciona os valorosos esforços de pesquisadores nas décadas de 60 e 70 onde, através de simulações em laboratório e campos de prova, foram detalhadamente catalogadas as assinaturas espectrais da maioria das substâncias presentes na superfície terrestre. Atualmente, a base de informações gerada é utilizada como referência por muitas pesquisas em sensoriamento remoto.

Para Meneses (2001), a radiometria espectral é uma das mais importantes, se não a mais fundamental área do conhecimento do sensoriamento remoto. Em um cenário tipicamente homogêneo, ou seja, com pouca variação do padrão de cobertura do solo, a discriminação dos diferentes materiais que o compõem torna-se simplificada. No entanto, segundo Myint (2003), a cobertura do solo em uma área urbana é caracterizada pela presença de vários materiais, como plástico, vidro, borracha, concreto, asfalto, metais, grama, arbustos, árvores e solo exposto. Esses materiais possuem diferentes respostas espectrais, que combinadas, 
formam o complexo cenário urbano, com assinaturas espectrais como as ilustradas na Figura 1.

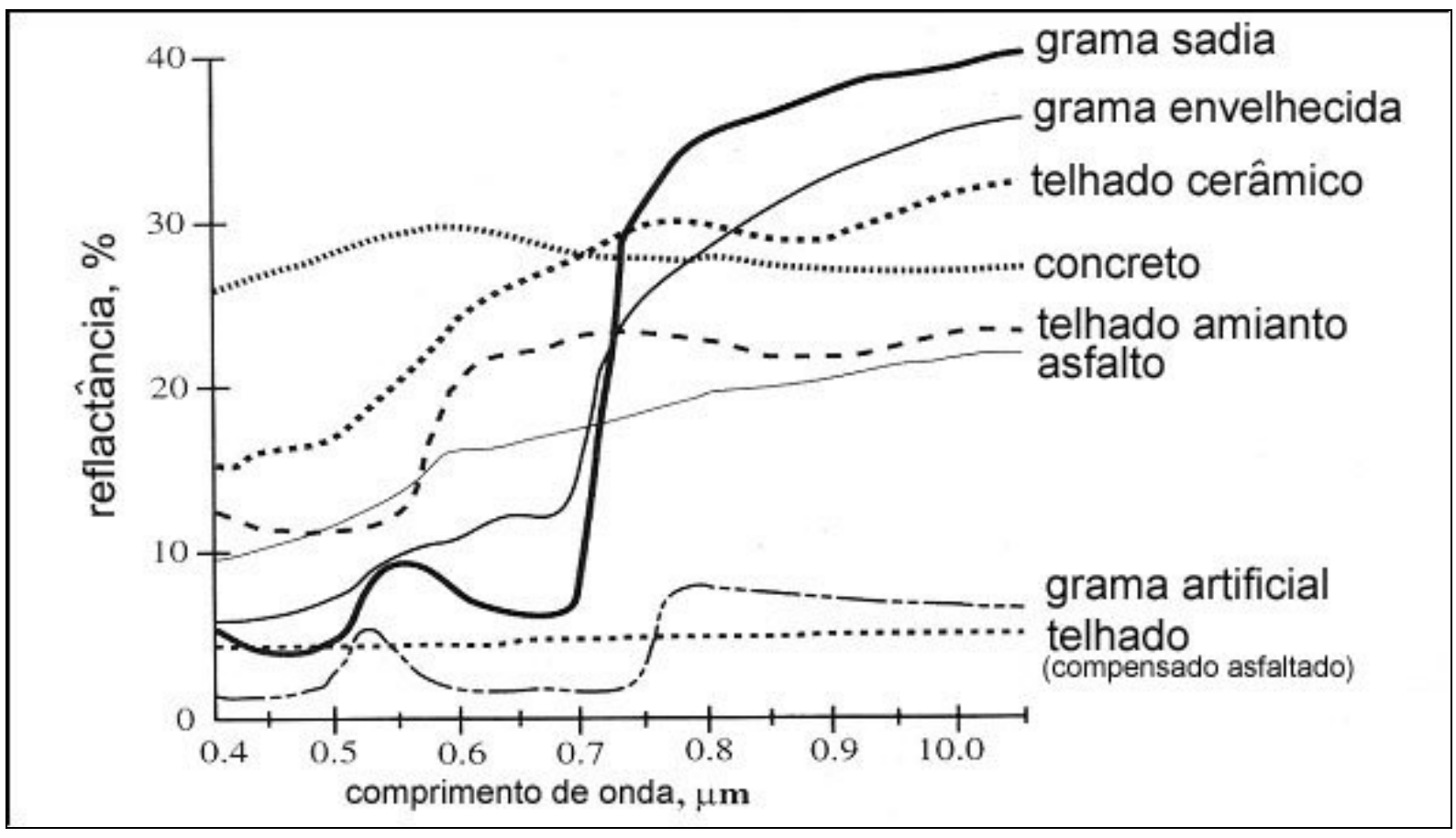

Figura 1 - Padrões de curvas espectrais de elementos comuns encontrados no ambiente urbano. As respostas espectrais foram obtidas em um ambiente controlado de laboratório, utilizando um espectroradiômetro modelo GER 1500. Adaptado de Jensen (2000).

Ainda, em se tratando das principais definições e terminologias utilizadas, faz-se necessário descrever o conceito de resolução que, em sensoriamento remoto é classificado como resoluções espacial, espectral, radiométrica e temporal (MOREIRA, 2001 e PINILLA, 1995).

O conceito de resolução espacial é familiar dentre usuários de imagens digitais. Segundo Tso e Mather (2001), quanto maior a resolução do sensor, melhor a capacidade de distinção entre diferentes objetos. Tecnicamente, a resolução espacial corresponde à capacidade do sistema sensor em discriminar a superfície imageada, de natureza contínua, em um número máximo de elementos discretos. Em sensoriamento remoto, a resolução espacial de uma imagem é dada em função do campo de visada do sensor, ou IFOV (Instantaneous Field Of View), que define a 
área abrangida pela imagem. Em termos práticos, atribui-se a unidade de medida de distância sobre o terreno, ou GSD (Ground Sample Distance) em função do ângulo de abertura do IFOV e da altitude do sensor.

Resolução radiométrica corresponde à capacidade do sistema sensor em discriminar os níveis de intensidade da radiância espectral da cena, e é quantificada em bit (ou nível de quantização). Resolução espectral corresponde à capacidade do sistema sensor em discriminar a radiância detectada em diferentes comprimentos de onda do espectro eletromagnético, e é quantificada pelo número de bandas espectrais discriminadas.

Por fim, resolução temporal refere-se à capacidade do sistema sensor em imagear a mesma região da superfície terrestre, quantificada pelo intervalo de tempo mínimo entre diferentes aquisições. Maiores detalhes podem ser acessados em Crosta (1992), INPE (2005), Jensen (1986), Moik (1980), Moreira (2001), Novo (1992), Pinilla (1995) e Schowengerdt (1993).

\subsection{EVOLUÇÃO DOS SISTEMAS SENSORES}

\subsubsection{O aumento da resolução espacial das imagens orbitais}

O aumento da resolução espacial tem sido visto como um dos resultados mais promissores na evolução dos sensores orbitais. Dowman (2001) afirma que o estágio tecnológico avançado dos últimos anos possibilitou que novos tipos de dados surgissem no cenário do sensoriamento remoto, numa freqüência até então não alcançada.

Em Aplin (2003), os satélites de sensoriamento remoto são classificados em três gerações, sendo a primeira geração caracterizada pelos instrumentos LANDSAT-MSS [sensor multiespectral de varredura - Multispectral Scanner Subsystem], em operação entre as décadas de 70 e início de 80. A segunda geração surgiu na década de 80 , a qual incluiu instrumentos como o LANDSAT-TM [Thematic Mapper] e o SPOT-HRV [High Resolution Visible]. A terceira geração de 
satélites teve início a partir dos anos 90, com o desenvolvimento de sensores de resoluções espacial, espectral, radiométrica e temporal mais apuradas. Ainda, segundo o mesmo autor, o desenvolvimento dessa terceira geração de satélites foi beneficiado pelo final da Guerra Fria e, conseqüentemente, pelo relaxamento das severas legislações governamentais envolvidas no sensoriamento remoto.

Considerando os lançamentos referentes à terceira geração de satélites de Sensoriamento Remoto, o programa espacial indiano, desenvolvido pela IRSO (Indian Space Resource Organization), lançou o terceiro instrumento da série IRS (Indian Resource Satellite), denominado IRS-1C, com resolução espacial de 5,8 metros obtidos em um sensor pancromático, porém com resolução radiométrica de 7 bits. Em 1997 foi lançado o IRS-1D, com características similares ao antecessor. Em 1993, foi lançado o satélite IRS-P6, também conhecido como RESSOURCESAT-1, com inovações quanto aos sensores de média resolução espacial, porém mantendo as características do sensor pancromático de alta resolução (DOWMAN, 2001).

Kressler, Kim e Steinnocher (2003) relatam o lançamento do satélite sulcoreano KOMPSAT-1, em Dezembro de 1999, como sendo o primeiro de uma família de satélites operados pelo Instituto Sul-Koreano de Pesquisas Espaciais KARI (Korean Aerospace Research Institute). A resolução espacial do sensor pancromático é de 6,6 metros. Juntamente com o IRS-1C e IRS-1D, as imagens de alta resolução do KOMPSAT-1 têm sido utilizadas para realçar as feições do terreno em composições coloridas, em especial para a aplicação de técnicas de fusão entre bandas multiespectrais de menor resolução (incluindo bandas espectrais de sensores de outros satélites).

A demanda por imagens de alta resolução espacial influenciou o desenvolvimento dos sensores do satélite SPOT-5, lançado em Maio de 2002. Embora as bandas multiespectrais do sensor HRG (High Resolution Geometric) permitam o imageamento com resolução de 10 metros, a banda pancromática o faz com resolução de 5 metros. No entanto, o SPOT-5 possui dois sistemas detectores idênticos, que podem ser combinados para gerar imagens com resolução espacial de 2,5 metros (LILLESAND, KIEFFER e CHIPMAN, 2004).

Segundo Dowman (2001) e Jacobsen (2004, 2002), a resolução espacial de 1 metro foi almejada pela comunidade de Sensoriamento Remoto desde 0 
primeiro lançamento do programa LANDSAT. Nesse sentido, o lançamento do satélite IKONOS II da empresa norte-americana Space Imaging LLC, em setembro de 1999, teve um papel fundamental para o estabelecimento das imagens de alta resolução espacial. Sua repercussão tomou grandes proporções, por se tratar de um programa destinado ao uso pela comunidade civil. No entanto, além da banda pancromática de 1 metro, o IKONOS II dispõe de um sensor multiespectral com 4 bandas, com resolução espacial de 4 metros.

Em Dezembro de 2000, a israelense ImageSat International lançou o satélite EROS-A, com resolução espacial de 1,8 metro, somente em modo pancromático. Em Outubro de 2002 a norte-americana DigitalGlobe lançou o QUICKBIRD, atingindo as resoluções espaciais de 0,61 metro e 2,40 metros, respectivamente para as bandas pancromáticas e multiespectrais (LILLESAND, KIEFFER e CHIPMAN, 2004). A Tabela 1 apresenta a seqüência cronológica dos lançamentos dos satélites de alta resolução espacial, bem como algumas características relevantes para o desenvolvimento desse trabalho, como nível de quantização, resolução espacial e abrangência da cena.

Tabela 1 - Quadro comparativo das resoluções espacial e temporal dos satélites operantes voltados ao imageamento em alta resolução espacial.

\begin{tabular}{|l|c|l|c|c|}
\hline \multicolumn{1}{|c|}{ Satélite } & Lançamento & \multicolumn{1}{c|}{ Resolução } & Quantização & Abrangência \\
\hline IRS-1C/IRS-1D & $1995 / 1997$ & $5,8 \mathrm{~m}$ pan & 7-bit & $70 \mathrm{Km}$ \\
\hline IKONOS & 1999 & $1 \mathrm{~m}$ pan / 4 m multi & 11-bit & $11 \mathrm{Km}$ \\
\hline KOMPSAT-1 & 1999 & $6,6 \mathrm{~m}$ pan & 8-bit & $17 \mathrm{Km}$ \\
\hline EROS-A & 2000 & $1,8 \mathrm{~m}$ pancromático & 11 -bit & $13.5 \mathrm{Km}$ \\
\hline QUICKBIRD & 2001 & 0,62 pan / 2,4 m multi & 11-bit & $16.5 \mathrm{Km}$ \\
\hline SPOT-5 & 2002 & $5 \mathrm{~m}(2,5 \mathrm{~m})$ pan & 8-bit & $60-80 \mathrm{Km}$ \\
\hline
\end{tabular}




\subsubsection{O aumento do nível de quantização nos novos sensores}

O avanço tecnológico contemporâneo tem possibilitado incrementar o nível de quantização das imagens em sensores digitais aerotransportados e sensores orbitais, transpondo os usuais 8 bits.

Segundo Crosta (1992), a capacidade do sistema visual humano em discernir tonalidades de cinza não vai além de 30 diferentes níveis, porém, quando se trata de discernir cores, esse número pula facilmente para algumas centenas de milhares. Embora esses 30 diferentes níveis representem um número significativamente inferior aos 256 tons de uma imagem digital tradicional de 8 bits, na prática, utiliza-se uma resolução radiométrica mais refinada, a fim de que a energia refletida pelas feições presentes na superfície terrestre possa ser contemplada na imagem digital, sem que haja perdas devidas à amplitude limitada do histograma.

Grande parte dos aplicativos de manipulação e de edição de imagens digitais foi desenvolvida para operar em imagens quantizadas em 8 bits, ou em composições coloridas de 24 bits. De forma análoga, grande parte das metodologias de análise foi desenvolvida com base em imagens dos programas LANDSAT e SPOT, ambas com resolução radiométrica de 8 bits por banda.

No entanto, mesmo as imagens de 8 bits têm-se mostrado inadequadas em alguns tipos de análises, como, por exemplo, no estudo de regiões cobertas por sombras (vide Figura 2), ou com alta freqüência quanto à variação da iluminação solar, mais especificamente em imagens urbanas de alta resolução. 


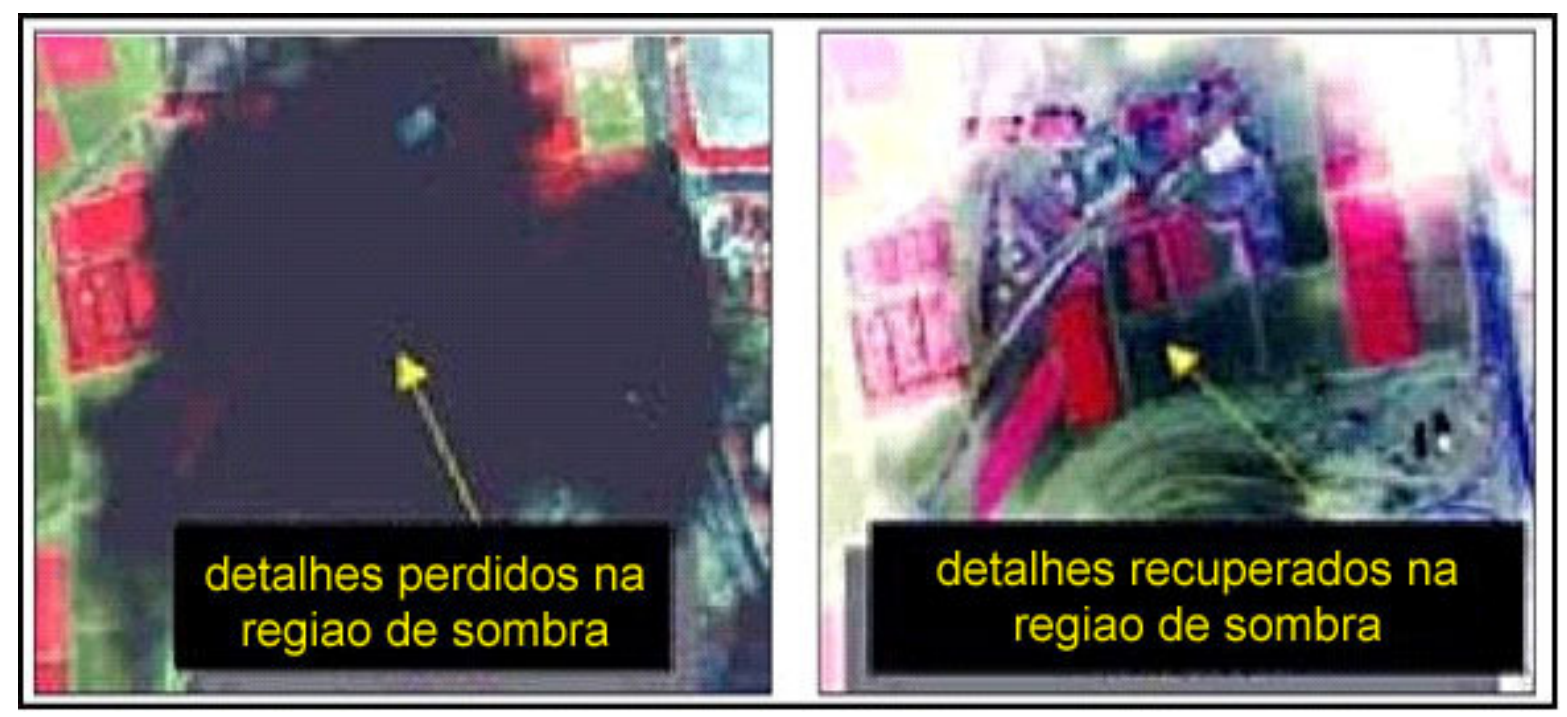

Figura 2 - Imagem IKONOS ilustrando a aparente perda de detalhamento das feições, em uma região coberta por sombra, e a posterior restauração das informações devido à quantização da imagem em 11 bits. Adaptado de Koyuncu (2002).

Frente a isso, os programas espaciais mais recentes, assim como os câmaras digitais aerotransportadas, estão sendo preparados para operar com níveis de quantização mais abrangentes. É o caso do satélite IKONOS II e QUICKBIRD, com imagens de 11 bits por banda (2048 níveis de cinza) e das câmaras digitais aerotransportadas ADS40 da Leica Geosystems e ULTRACAM da Vexcel Corporation, que produzem imagens em 12 bits por banda (4096 níveis de cinza).

Todavia, assim como o aumento das resoluções espacial e espectral, 0 aumento da resolução radiométrica implica diretamente no aumento da quantidade de dados a serem processados e armazenados nos computadores. Para se ter uma idéia, uma banda quantizada em 11 bits, requer $37,5 \%$ mais memória de armazenamento que uma banda quantizada em 8 bits. Em alguns casos, esse aumento pode ser considerado como fator decisivo para que as imagens dos novos satélites sejam reamostradas para 8 bits (256 tons de cinza por banda). Outro problema passa a ser a dificuldade na interpretação e manipulação do histograma, visto que muitos dos aplicativos atualmente disponíveis não se encontram adaptados para operar com tal nível de quantização (KOYUNCU, 2002). 


\subsection{EXPLORAÇÃO DA IMAGEM DIGITAL EM SENSORIAMENTO REMOTO}

Para Pinilla (1995), o sensoriamento remoto é uma técnica ainda em desenvolvimento, que tem produzido resultados adequados para diversas aplicações de estudos temáticos. Independente do campo de aplicação, o sensor a bordo do satélite se comporta como um sistema formador de imagens, que opera sobre o sinal de entrada, mediante os dispositivos ópticos, para produzir o sinal de saída.

Uma vez disponibilizadas as imagens, nelas são aplicadas técnicas de processamento digital, utilizando recursos cada vez mais poderosos. Segundo Gonzales e Woods (1993), o interesse no desenvolvimento de métodos de processamento digital de imagens parte de duas principais áreas de aplicação: 1) melhoria da informação gráfica para interpretação humana e 2) processamento de dados para automatização de processos de interpretação. O sensoriamento remoto envolve ambas as áreas mencionadas. Embora ocorra uma busca crescente por processos automáticos de classificação, grande parte de suas aplicações demanda a visualização da imagem, seja como produto final, seja para a seleção de amostras de treinamento para extração de informações.

\subsubsection{Imageamento em múltiplas bandas}

Desde sua origem, o sensoriamento remoto tem se apoiado na espectrometria, responsável pelo mapeamento do comportamento espectral dos diferentes elementos presentes na superfície terrestre. Em teoria, uma vez conhecida a resposta espectral de um determinado elemento em diferentes regiões do espectro eletromagnético, essa informação pode ser utilizada para que o mesmo possa ser discriminado a partir de uma imagem multiespectral, cujas bandas espectrais sejam representativas para tal análise.

Imageamento em múltiplas bandas, segundo Lillesand, Kieffer e Chipman (2004), corresponde à captura simultânea de imagens com semelhança quanto a geometria, porém discretizadas em diferentes bandas do espectro eletromagnético. 
Desconsiderando o número e a largura das faixas espectrais dessas bandas, em geral somente três bandas são selecionadas e visualizadas simultaneamente, devido ao emprego das cores aditivas primárias, representadas pelo espaço de cores RGB (Red, Green e Blue, vermelho, verde e azul, respectivamente) na construção dos dispositivos luminosos dos monitores dos computadores. Todavia, isso não impede que um número maior de bandas seja utilizado no processo de classificação. Dado que as imagens multispectrais empregadas em sensoriamento remoto são matrizes $n$-dimensionais e, como tais, manipuladas computacionalmente como números, é intuitivo dizer que a análise computacional dessas imagens transcende a limitada capacidade visual humana, bem como o limitante espaço de cores dos dispositivos de visualização dessas imagens.

$\mathrm{Na}$ prática, a melhor combinação entre as bandas multiespectrais para a discriminação dos elementos presentes numa cena varia de acordo com o padrão da resposta espectral dos elementos de interesse. Muitas vezes, os elementos de interesse na cena podem ser discernidos a partir de informações distintas em diferentes bandas espectrais.

No entanto, em sensoriamento remoto, o imageamento multiespectral tem como agravante a alta correlação entre as bandas, o que pode influenciar significativamente na discriminação dos elementos de interesse na cena. Recursos como análises de Componentes Principais e Tasselled Cap vêm sendo utilizados como ferramenta de transformação do sistema de coordenadas do espaço de atributos, visando à redução da dimensionalidade dos dados originais. Com base nos novos dados, parâmetros estatísticos dos agrupamentos são extraídos de forma a promover a melhor separabilidade entre as classes espectrais, correlacionadas nas bandas originais. Uma melhor descrição sobre técnicas de manipulação do espaço multidimensional de atributos em sensoriamento remoto pode ser vista em Schowengerdt (1997) e Tso e Mather (2001).

A combinação de diferentes bandas espectrais também pode colaborar para a melhor discriminação dos elementos. Operações aritméticas entre bandas espectrais promovem novos valores que, por sua vez, podem fornecer subsídios para aprimorar a discriminação dos elementos, ou mesmo, fornecer novas informações passíveis de serem analisadas. 


\subsubsection{Operações entre bandas}

Em termos computacionais, as operações entre bandas são descritas como operações aritméticas entre os elementos de diferentes matrizes (ASPRS, 2004). Em termos práticos, essas operações são realizadas pixel a pixel, e envolvem os níveis de intensidade dos pixels a fim de determinar um novo nível de informação. Matematicamente, as operações entre bandas são expressas em forma de função entre as imagens.

$$
\mathrm{H}(\mathrm{x}, \mathrm{y})=\mathrm{C}[f(\mathrm{x}, \mathrm{y}), g(\mathrm{x}, \mathrm{y})]
$$

Onde: $\mathrm{C}$ descreve o operador aritmético aplicado pixel a pixel para as imagens $f$ e $g$.

Em sensoriamento remoto existem várias aplicações de operações entre bandas espectrais que visam gerar informações originalmente não contempladas pelas mesmas. Pinilla (1995) menciona que a simples razão entre bandas espectrais pode proporcionar um melhor critério de separabilidade, em casos onde a discriminação da cobertura do solo é dificultada pela similaridade com que as feições relativas ao solo são apresentadas em cada banda espectral.

Segundo Jensen (2000), cientistas têm extraído e modelado diversas variáveis biofísicas da vegetação através de dados de sensoriamento remoto. Parte desse esforço resultou nos chamados índices de vegetação, definidos como medidas radiométricas obtidas por funções, como indicadores da abundância relativa de vegetação verde. Uma das mais tradicionais razões entre bandas é conhecida como NDVI (Normalized Difference Vegetation Index), ou índice de vegetação por diferença normalizada, definido originalmente a partir de imagens MSS-LANDSAT como sendo a diferença dividida pela soma entre as bandas vermelho e infravermelho próximo, conforme mostrado na eq.(1).

$$
N D V I=\frac{(\text { Infravermelho próximo }- \text { Vermelho })}{(\text { Infravermelho próximo }+ \text { Vermelho })}
$$

Em linhas gerais, a grande maioria dos já conceituados índices e operações aritméticas entre bandas espectrais está voltada para o emprego de 
imagens de média e baixa resolução, visando o monitoramento ambiental e o monitoramento do potencial agrícola. No entanto, a aplicação de índices a partir de operações entre bandas vem tomando um volume crescente também em imagens de alta resolução, e em aplicações urbanas. Gerke, Heipke e Straub (2001) utilizam o NDVI para auxiliar a separação ente a massa de vegetação das superfícies dos telhados, na extração de edificações a partir de imagens aéreas ; De Kok, Wever e Fockelmann (2003) o utilizam como parâmetro para reforçar a discriminação das alterações do ambiente urbano a partir de imagens do satélite IKONOS II ; Alvarez (2004), utilizou diferentes índices para caracterizar a qualidade do espaço verde urbano, recorrendo a imagens de satélite, fotografias aéreas e videografia, e O'Hara (2005) aplicou o NDVI em análises multitemporais de imagens do satélite QUICKBIRD, visando detectar e classificar as áreas onde houve alterações na cobertura do solo.

Existem, no entanto, diversos outros índices, desenvolvidos no sentido de proporcionar melhor um poder de discriminação entre as informações envolvidas na análise de bandas espectrais em conjunto. Um exemplo é o índice utilizado para mapear as áreas de solo exposto em Nobrega et al (2006), que envolve a terceira componente principal e a banda azul, em uma função desenvolvida para classificação baseada em objetos, descrita em detalhes no Capítulo 4.

\subsubsection{Fusão entre bandas}

O espaço de cores IHS (Intensity, Hue e Saturation), definido pelas componentes Intensidade, Matiz e Saturação, representa esquematicamente a forma com que o sistema visual humano opera. Segundo Gonzales e Woods (1993), as componentes $\mathrm{H}$ e S estão intimamente ligadas e tornam mais fácil o reconhecimento visual das variações das cores nas imagens. Por sua vez, a componente de intensidade independe totalmente das demais componentes de cor. Essa independência permitiu com que fossem desenvolvidos processamentos de fusão entre bandas espectrais visando obter composições coloridas com resoluções mais 
refinadas, uma vez que é possível compor uma nova imagem a partir de transformações entre espaços de cores distintos.

Em sensoriamento remoto, são comuns os satélites que possuem sensores operando simultaneamente em diferentes resoluções espacial e espectral. As imagens multiespectrais normalmente são obtidas com resoluções espaciais menores que a pancromática. Nesse sentido, as técnicas de fusão entre bandas em sensoriamento remoto foram desenvolvidas para promover imagens resultantes que possuam características multiespectrais compatíveis às das bandas adotadas na composição escolhida, e resolução espacial compatível à da banda pancromática, conforme ilustra a Figura 3.

Lillesand, Kieffer e Chipman (2004) mencionam a manipulação das componentes dos espaços RGB e IHS como base do processo de fusão de bandas. Em suma, eleitas as bandas multiespectrais originais, cria-se a composição colorida (ou falsa-cor). As bandas multiespectrais são então reamostradas para a resolução da banda pancromática. A composição colorida é convertida para o espaço de cores IHS. No espaço IHS, a componente I é substituída pela banda pancromática e a composição colorida é novamente convertida para o espaço RGB.

No entanto, a substituição direta da componente de intensidade pela banda pancromática nem sempre produz o melhor resultado final, em termos de balanceamento de cores e fidelidade espectral das informações originais. Nessa situação, uma combinação ponderada deve ser adotada entre as bandas pancromática e multiespectrais (LILLESAND, KIEFFER e CHIPMAN, 2004). 

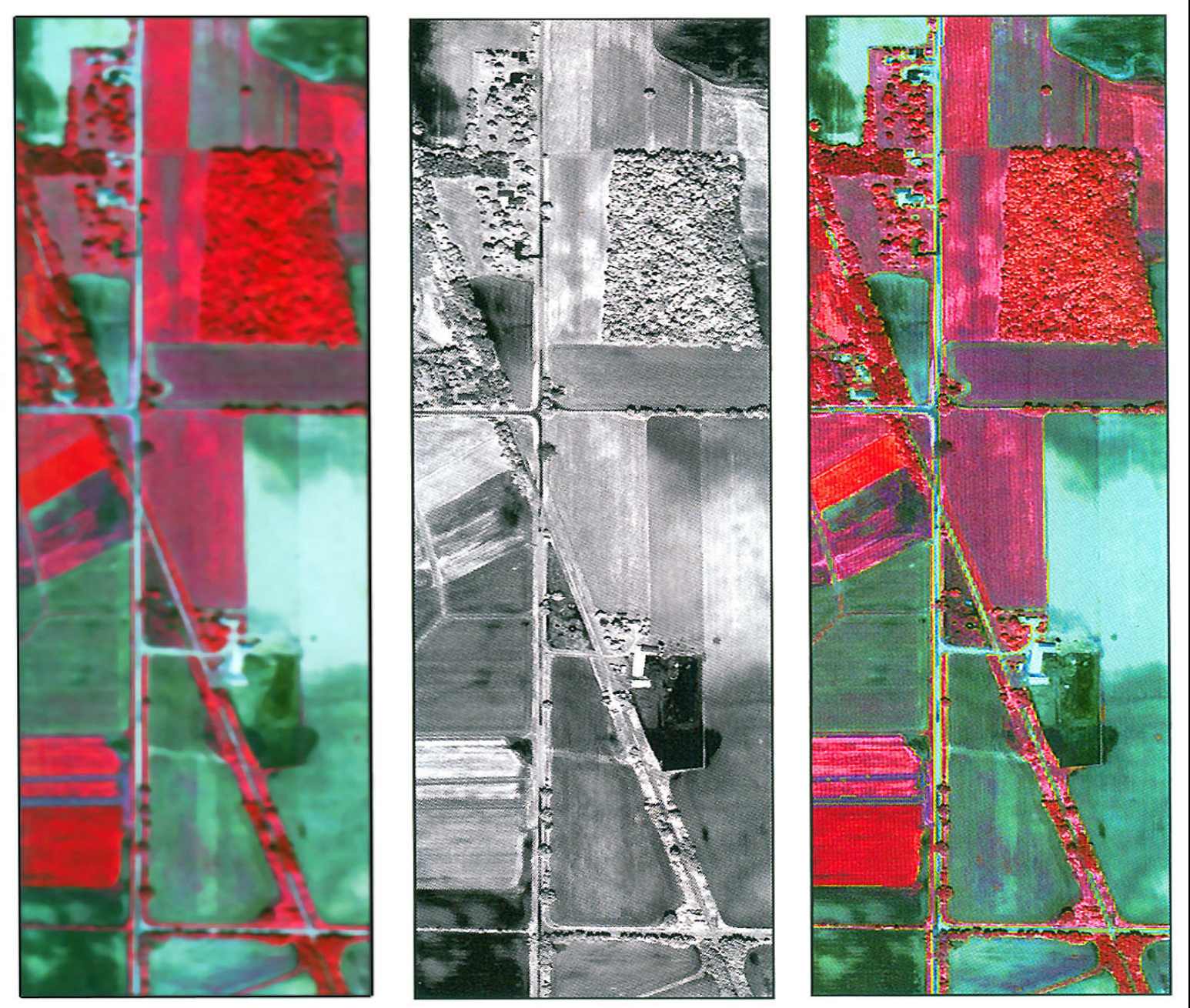

Figura 3 - Fusão das bandas multispectrais e pancromática do satélite IKONOS II, com quatro metros e um metro, respectivamente (LILLESAND, KIEFFER e CHIPMAN, 2004).

\subsubsection{Segmentação}

Gonzales e Woods (1992) descrevem o processo de segmentação como a divisão da imagem em partes menores ou objetos de interesse, até que os mesmos sejam isolados. Segundo os mesmos autores, a automatização desse processo é considerada como uma das tarefas mais trabalhosas no processamento de imagens. Em algumas situações, como em aplicações industriais de inspeção, pode-se controlar o ambiente, minimizando possíveis problemas na imagem, uma vez que o ambiente é controlado. No entanto, em outras aplicações, como em 
imagens aéreas [e imagens orbitais], não há controle sobre o ambiente natural, o que dificulta significativamente o processo.

Os algoritmos de segmentação de imagens digitais são usualmente baseados em duas propriedades: descontinuidade e similaridade. Simões (2000) menciona que na segmentação baseada em descontinuidade, a partição é baseada em alterações nos níveis da função da imagem, que são decorrentes das diversas situações na cena como, por exemplo, descontinuidade da normal das superfícies, descontinuidade em profundidade, descontinuidade na reflectância da superfície e descontinuidade de iluminação. Ainda, segundo Simões (2000), a segmentação baseada em similaridade busca agrupar regiões com características semelhantes, como, por exemplo, texturas ou cores.

A detecção da descontinuidade pode ser dada por ponto, linha e bordas, ou pela combinação de ambos, recorrendo a máscaras de convolução e cálculos de gradientes, como o Laplaciano e o Sobel (GONZALES e WOODS, 1993). Outros métodos podem ser empregados na detecção de elementos lineares, como por exemplo, a transformada de Hough, que relaciona o ângulo de direção dos segmentos lineares detectados, ou mesmo recorrendo aos operadores morfológicos de imagens digitais.

Segundo Simões (2000), no contexto da segmentação por similaridade, as abordagens tradicionais dividem-se em dois grupos: 1) as que fazem uso da relação topológica dos elementos da imagem, como o crescimento de regiões, e 2) as que não fazem uso de informação topológica, caso típico da imposição de limiares (thresholding).

Um dos algoritmos mais populares para a segmentação pela análise da vizinhança dos pixels é o crescimento de regiões (region growing). Gonzales, Woods e Eddins (2004) e Gonzales e Woods (1993) sugerem a segmentação por crescimento de regiões, para agrupar os pixels pertencentes a uma determinada classe, se o valor da diferença do nível de intensidade do pixel em questão para com o pixel vizinho de referência (denominado pixel semente) for menor que o valor préestabelecido.

Embora o crescimento de regiões use limiares, vale ressaltar que a comparação do valor do pixel aos limiares leva em consideração a relação de 
vizinhança. Para cada pixel, são analisados seus vizinhos e, dentro das condições impostas pelo limiar, o pixel analisado passa, ou não, a fazer parte do agrupamento em formação. O processo é executado iterativamente até que nenhum pixe/ vizinho ao segmento apresente valor de intensidade característico da categoria formada.

O conceito de vizinhança em uma imagem digital esta ligado à conectividade dos seus elementos, descrita em detalhes por Vincent (1993) e Gonzales e Woods (1993) e ilustrado na Figura 4. Basicamente, os dois grupos de conectividade levam em consideração os elementos imediatamente vizinhos (acima, abaixo, esquerda e direita), o que caracteriza a vizinhança de conectividade 4. A consideração para com os elementos diagonais caracteriza a vizinhança de conectividade 8 .

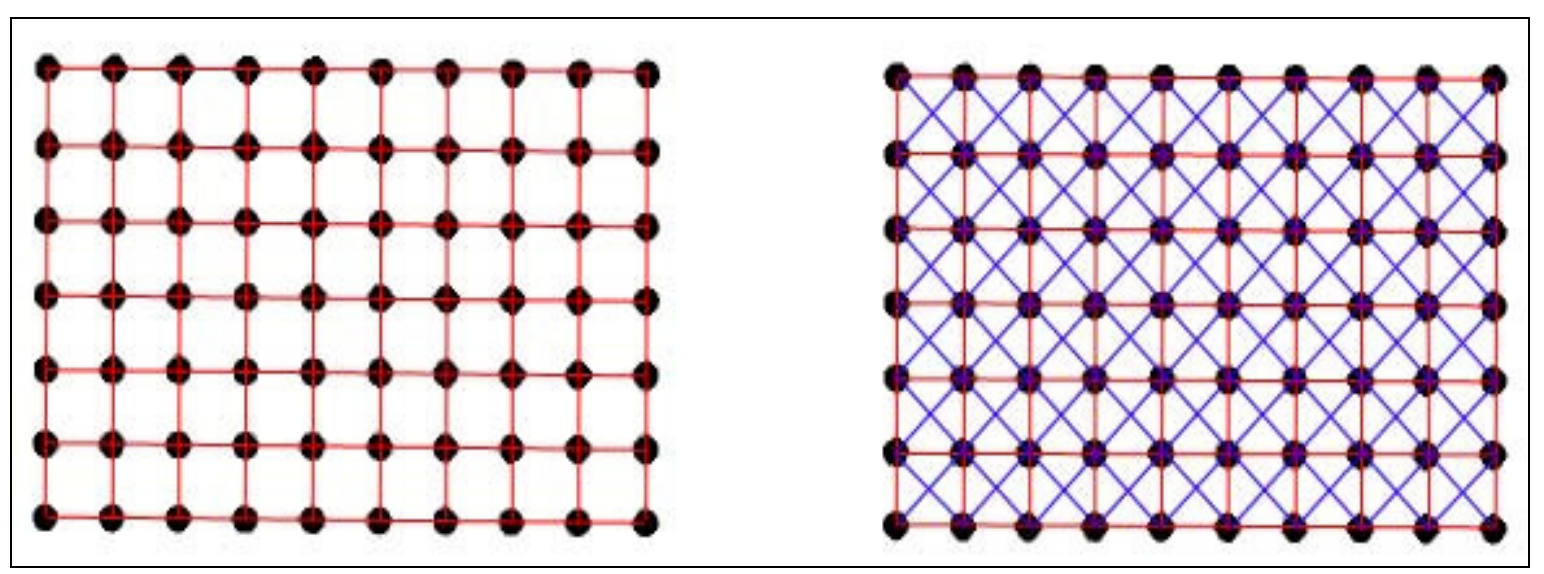

Figura 4 -llustração da vizinhança de conectividade 4 (esquerda) e da vizinhança de conectividade 8 (direita). Adaptado de Vincent (1993).

Sobretudo, o processo de segmentação de imagens, particularmente para o sensoriamento remoto, vem ganhando proporções significativas pelo aumento de sua demanda como etapa que antecede o processo de classificação. INPE (2005) propõe o uso de segmentação de imagens como uma etapa anterior ao processo de classificação, como forma de superar algumas das limitações apresentadas pelos classificadores convencionais pixel a pixel. Desta forma, os segmentos gerados são utilizados para auxiliar a seleção das amostras de treinamento, em especial para imagens de maior resolução espacial. Trabalhos recentes como Antunes, Lingnau e Silva (2003), Centeno et al (2003), De Kok, Wever e Fockelmann (2003), Frauman e 
Wolff (2005), Gwynn (2005), Kressler, Kim e Steinnocher (2003), Moham, Kadam e Rao (2003), O'Hara (2005), Nobrega et al (2006) e Shackelford e Davis (2003) incluem o processo de segmentação como base para a criação dos objetos, posteriormente classificados.

Antunes (2003) explica que o emprego exclusivo da heterogeneidade espectral (composta pela soma dos desvios padrão dos níveis de cinza para uma determinada banda, ponderados pelos respectivos pesos) como base para segmentação, resulta na fragmentação excessiva da imagem, principalmente em se tratando imagens cuja textura seja significativa.

Baatz e Schäpe (2001) descrevem critérios de similaridade dos segmentos controlados por limiares relacionados não somente a cor, mas também a forma. No modelo de Baatz e Schäpe (2001) a cor é diretamente relacionada à homogeneidade espectral e a forma à homogeneidade espacial. Esse conceito vem sendo amplamente empregado em segmentações de imagens voltadas para a classificação orientada a objetos, onde parte das informações atribuídas às regras de classificação é extraída da geometria dos segmentos.

\subsubsection{Morfologia matemática}

O conceito de morfologia matemática, desenvolvido na França nos anos 60, tomou grandes proporções nas décadas seguintes quando aplicados em análises de imagens, em especial áreas ligadas à microscopia. Em geral, o termo morfologia esta relacionado ao estudo de formas e estruturas de animais e plantas. Em termos práticos, o conceito de morfologia matemática pode ser visto em Gonzales, Woods e Eddins (2004), que apresentam processamentos em imagens digitais voltados a extração de componentes passíveis de serem utilizadas para a descrição de forma e estrutura, como esqueletos e bordas dos objetos presentes na imagem. Banon e Barreira (1994) apresentam em detalhes os fundamentos da morfologia matemática, suas aplicações e desenvolvimentos no campo do processamento digital de imagens. Vale mencionar que os conceitos sobre morfologia matemática tratados nesta pesquisa são referentes a imagens binárias. 
McAndrew (2004) menciona que a morfologia matemática pode ser desenvolvida de diversas formas, porém, em processamento de imagens utilizam-se normalmente métodos baseados em operadores morfológicos desenvolvidos a partir de translações e reflexões de elementos estruturantes sobre a imagem.

Operadores morfológicos primários, como dilatação e erosão, possibilitam que uma determinada feição presente na imagem tenha suas dimensões expandidas ou retraídas, respectivamente. Em outras palavras, considerando um objeto linear, mais precisamente uma via extraída através do processo de classificação, essa via pode sofrer um afinamento ao utilizar o operador morfológico de erosão, ou um alargamento ao utilizar um operador morfológico de dilatação.

A combinação dos operadores morfológicos de dilatação e de erosão propicia a construção de outros operadores morfológicos, tais como a abertura e o fechamento. Abertura, em morfologia matemática, corresponde ao processo de erosão seguido pela dilatação. Em termos práticos, o operador morfológico de abertura promove a remoção de regiões nos objetos que não contém o elemento estruturante, a suavização dos contornos dos objetos, quebras em conexões estreitas e remoção de saliências estreitas. Por sua vez, o operador morfológico de fechamento é produzido a partir da dilatação seguida pela erosão. Assim como a abertura, o fechamento provoca a suavização dos contornos dos objetos e, de forma contrária à abertura, o fechamento geralmente une pequenas lacunas, preenche regiões estreitas dos objetos e preenche lacunas menores que 0 elemento estruturante.

A combinação de operadores morfológicos de dilatação e erosão possibilita a criação de uma transformação, utilizada para auxiliar a detecção de formas, denominada Hit-or-Miss (acerto e erro). Essa transformação utiliza dois elementos estruturantes, $B_{1}$ e $B_{2}$, conforme apresentado na Tabela 2. Gonzales e Woods (1993) relatam que a transformação Hit-or-Miss contém todos os pontos em que, simultaneamente, ocorrem concordâncias entre $A$ e $B_{1}$ (acerto) e concordâncias entre o complemento de $A\left(A^{C}\right)$ e $B_{2}$. A Figura 5 ilustra os resultados da ação desses operadores morfológicos.

O emprego dos operadores morfológicos possibilitou que diversas soluções de filtragem, detecção de bordas e preenchimento de objetos fossem 
desenvolvidas através de morfologia matemática de imagens. Neste trabalho, o emprego de morfologia matemática fez-se necessário como forma de obter elementos lineares, empregados na análise linear de correspondência, entre as vias detectadas e os eixos das vias referenciais, conforme a metodologia sugerida por Zhang, Murai e Baltsavias (1999).

Tabela 2 - Síntese de alguns dos principais operadores de morfologia matemática utilizados nesse trabalho. Adaptado de Gonzales e Woods (1993).

\begin{tabular}{|c|c|}
\hline OPERADOR & EQUAÇÃO \\
\hline Translação & $(A)_{x}=\{c \mid c=a+x$, para $a \in A\}$ \\
\hline Reflexão & $B^{R}=\{x \mid x=-b$, para $b \in B\}$ \\
\hline Complemento & $A^{C}=\{x \mid x \notin A\}$ \\
\hline Dilatação & $A \oplus B=\left\{x \mid\left(B^{R}\right)_{x} \cap A \neq 0\right\}$ \\
\hline Erosão & $A \ominus B=\left\{x \mid(B)_{x} \subseteq A\right\}$ \\
\hline Abertura & $A \circ B=(A \ominus B) \oplus B$ \\
\hline Fechamento & $A \bullet B=(A \oplus B) \ominus B$ \\
\hline Hit-or-Miss & $A S B=\left(A \ominus B_{1}\right) \cap\left(A^{C} \ominus B_{2}\right)$ \\
\hline Afinamento & $\mathrm{A} \otimes \mathrm{B}=\mathrm{A}-(\mathrm{A} S \mathrm{~B}) \quad\{B\}=\left\{B^{1}, B^{2}, \ldots\right.$ \\
\hline Esqueletonização & $S_{k}(A)=U_{k}\{(A \ominus k B\}$ \\
\hline
\end{tabular}

Para obter esses elementos lineares via morfologia matemática, dois procedimentos podem ser aplicados: afinamento e esqueletonização. Afinamento, como o próprio nome o sugere, corresponde à redução na largura de objetos isentos de lacunas. Esse processo pode ser interativo até que a largura atinja a dimensão mínima de 1 pixel. Por sua vez, esqueletonização corresponde a um processo interativo de sucessivas erosões nos objetos presentes na imagem a fim de se determinar o esqueleto desses objetos. McAndrew (2004) explica os esqueletos de objetos como sendo uma coleção de linhas e curvas que encapsulam o tamanho e a forma dos mesmos. 


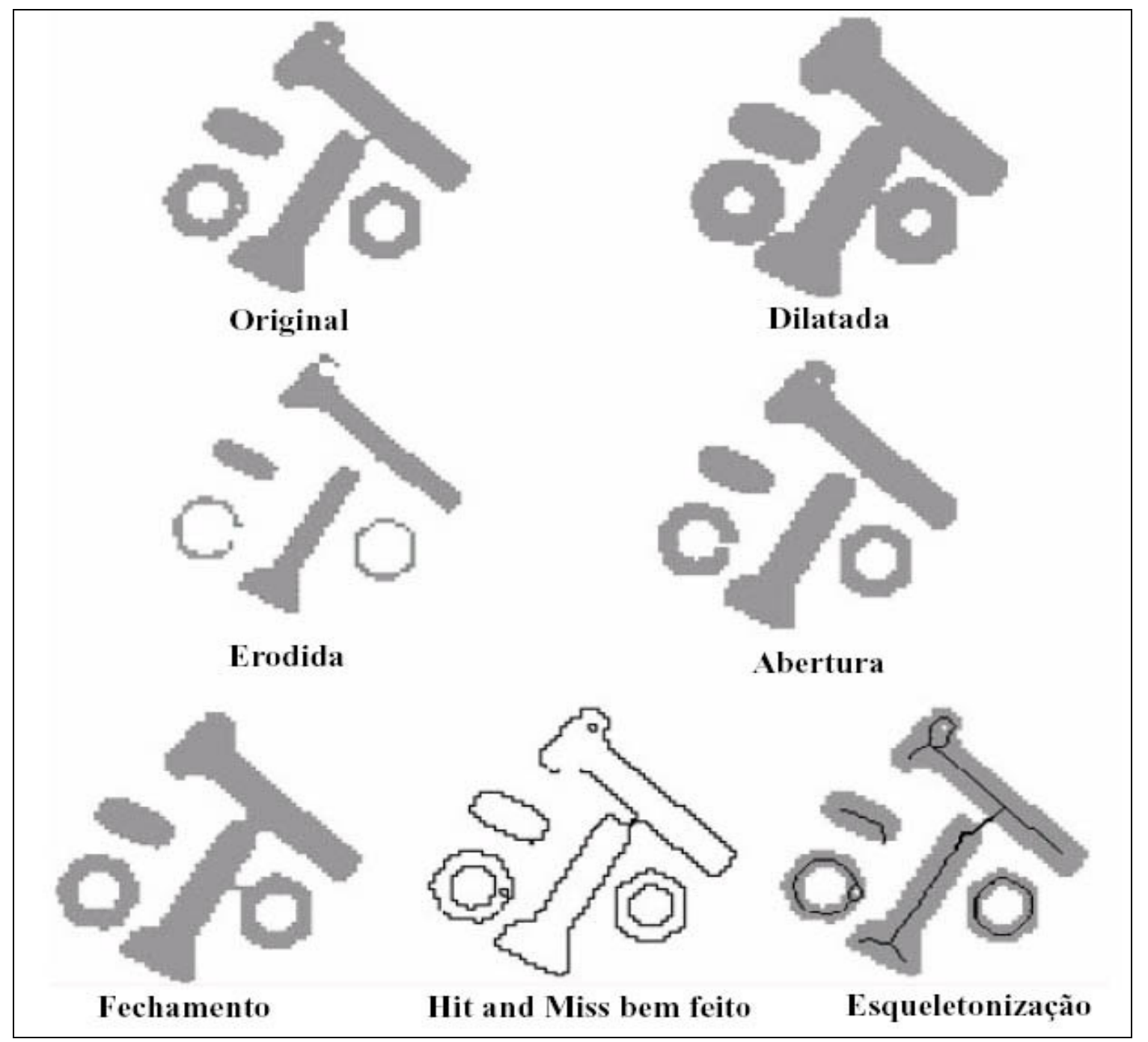

Figura 5 - Visão geral das operações de morfologia matemática binária.

\subsection{ESTADO DA ARTE DA EXTRAÇÃO DE INFORMAÇÕES EM SENSORIAMENTO REMOTO}

A evolução do sensoriamento remoto tem sido constante desde seu surgimento. As inovações tecnológicas utilizadas permitiram avanços nas resoluções espacial, espectral, radiométrica e temporal, possibilitando estudar em detalhes as feições presentes na superfície terrestre bem como os fenômenos que nela interagem. 
Ao analisar a evolução dos sistemas sensores em relação ao espectro eletromagnético, percebe-se que o poder de discriminação entre os alvos aumenta quando se utilizam mais faixas espectrais e, em sendo estas faixas mais estreitas, há uma redução da informação redundante entre diferentes faixas ou bandas. Com o aumento da resolução radiométrica os detalhes são mais preservados, em especial em áreas urbanas. Por sua vez, o aumento da resolução espacial propicia a melhor discriminação dos objetos presentes na cena (NEUBERT e MEINEL, 2005), além de contribuir para a redução do problema da mistura espectral dos pixels (NEUBERT e MEINEL, 2005 ; De KOK et al, 2003).

Como consequência, independente da resolução em questão, o volume de dados gerados tornou-se extremamente elevado. O surgimento dos sensores hiperespectrais implicou diretamente no aumento do número de bandas e, consequentemente, no aumento do volume de dados.

Embora o aumento da resolução espacial tenha, em geral, despertado o maior interesse por parte da maioria dos usuários, em função da riqueza de detalhes possíveis de serem visualizados, algumas dificuldades são, no entanto, atribuídas ao seu emprego em processos de classificação. Para Schiewe e Tufte (2005), em função da melhoria da resolução espacial, pode haver um aumento da variabilidade interna, ou seja, do ruído interno dentro das classes de cobertura do solo. Como resultado, os classificadores tradicionais, baseados apenas nas informações espectrais dos pixels têm seus desempenhos reduzidos.

Segundo Andrade, Botelho e Centeno (2003), Baltsavias (2004), Baltsavias, Pateraki e Zhang (2001), Centeno et al (2003), Guennadi e Yerach (2003), Huang, Bingfanf e Jinlong (2003), Repaka et al (2004) e Tso e Mather (2001), as técnicas tradicionais de classificação não têm demonstrado grande eficiência quando aplicadas em imagens de alta resolução espacial, especialmente em áreas urbanas. Embora essas técnicas sejam funcionais para discernir as classes, seu desempenho é limitado para dados interclasses. Nesse contexto, as técnicas de classificação baseadas em lógica fuzzy podem ser empregadas em situações nas quais a análise dos dados requer um determinado grau de incerteza (TSO e MATHER, 2001). 
Trabalhos mais recentes apontam o emprego de informações contextuais das feições presentes na imagem, como saída para a classificação de imagens de alta resolução. Essas técnicas utilizam informações independentes dos pixels bem como sua relação com seus agrupamentos vizinhos. Nesse contexto, destacam-se as técnicas de classificação baseadas na análise textural de imagens e técnicas baseadas em segmentação. Outras técnicas sugerem o emprego de mais de uma fonte de informação, como imagens de diferentes sensores para uma mesma região ou informações altimétricas (BAATZ et al, 2004 ; BENEDIKTSSON, SWAIN e ERSOY, 1990 ; TSO e MATHER, 2001). Há também a classificação hierárquica, que utiliza processamentos em níveis decrescentes de resolução, gerando classes principais e as classes dependentes, num processo seqüencial de refinamento (BAATZ e SCHÄPE, 2001).

Para Baatz et al (2004) e Blaschke e Strobl (2001), o emprego de informações extraídas de conjuntos de pixels, por si só, ainda tem apresentado resultados insatisfatórios para áreas urbanas. A introdução de informações oriundas do conhecimento do analista sobre as feições representadas na imagem, para compor as regras de decisão, tem mostrado a melhora significativa da discriminação de alvos urbanos (BALTSAVIAS, 2004 ; GERKE, 2002 ; HEIPKE, PAKZAD e WILLRICH, 2004).

A base de conhecimento passa então a ser utilizada para apoiar a criação das regras e das estratégias de classificação nas imagens, sobretudo no ambiente urbano. Essa modelagem vai além do emprego de informações numéricas extraídas dos elementos. Relacionamento entre elementos vizinhos e sua interação no ambiente urbano passam a ter papel importante e decisivo. A classificação em imagens, que tradicionalmente visa discriminar classes de cobertura do solo, passa também a inferir sobre o uso do solo.

No entanto, vale ressaltar que o modelo classificatório baseado em informações contextuais é, mais do que nunca, um processo supervisionado e, como tal, é altamente dependente de um analista. 


\subsection{CLASSIFICAÇÃO EM IMAGENS}

Classificação em imagens, segundo Rees (1999), refere-se ao processamento do qual decisões quantitativas são tomadas com base nas informações presentes na imagem, através do agrupamento de pixels ou regiões da imagem em classes que representem diferentes padrões de cobertura do solo, visando como saída o mapeamento temático extraído da imagem.

Lillesand, Kieffer e Chipman (2004) descrevem a classificação em imagens em função do padrão de processamento dos dados, ou seja, reconhecimento do padrão espectral, espacial ou temporal, recorrendo, respectivamente, às análises da reflectância dos pixels nas diferentes bandas, análises da relação espacial entre os pixels e análises das diferenças entre duas ou mais cenas tomadas em épocas diferentes.

A busca pelo reconhecimento da cobertura do solo por sensoriamento remoto tem evoluído desde a década de 70 e ganhou proporções a partir dos dados multiespectrais do programa LANDSAT. Embora haja, atualmente, metodologias de classificação baseadas em análises temporais e espaciais, a grande maioria dos procedimentos de classificação em imagens recorre a análise espectral. Baseado no fato de que diferentes feições no solo podem manifestar diferentes respostas espectrais, várias técnicas de classificação dessas informações foram desenvolvidas utilizando dados espectrais.

Jensen (1986) menciona que o processo de classificação de imagens multiespectrais pode ser desenvolvido utilizando métodos supervisionados e não supervisionados. Segundo o nome sugere, na classificação supervisionada é desenvolvida com base em amostras de treinamento, ou seja, os pixels da imagem são classificados segundo regras que os compara a padrões de classes previamente definidos pelo operador. Por sua vez, a classificação não supervisionada é desenvolvida sem que o operador especifique os padrões que irão compor as classes. Com isso, são requeridos cálculos computacionais para definir os agrupamentos dos padrões espectrais similares. Fica a cargo do operador, basicamente, definir o rótulo das classes ou, quando necessário, o número de 
classes. Maiores detalhes podem ser encontrados em Duda e Hart (1973), Jensen (1986), Kohn (1998), Lillesand, Kieffer e Chipman (2004), Schowengerdt (1997) e Schowengerdt (1983).

Para o melhor entendimento de como as técnicas de classificação procedem na formação e a separação dos agrupamentos, as análises dos agrupamento dos padrões espectrais utilizam o espaço n-dimensional de atributos, aqui ilustrado, hipoteticamente, no plano bidimensional para as bandas 4 e 3 , conforme ilustra a Figura 6. Os diferentes elementos imageados na superfície terrestre podem reproduzir reflectâncias diferentes para faixas espectrais distintas. Quando analisadas em conjunto, os diferentes padrões de reflectância formam agrupamentos no espaço de atributos, que passam a representar os padrões espectrais das classes de cobertura do solo para a área imageada. 


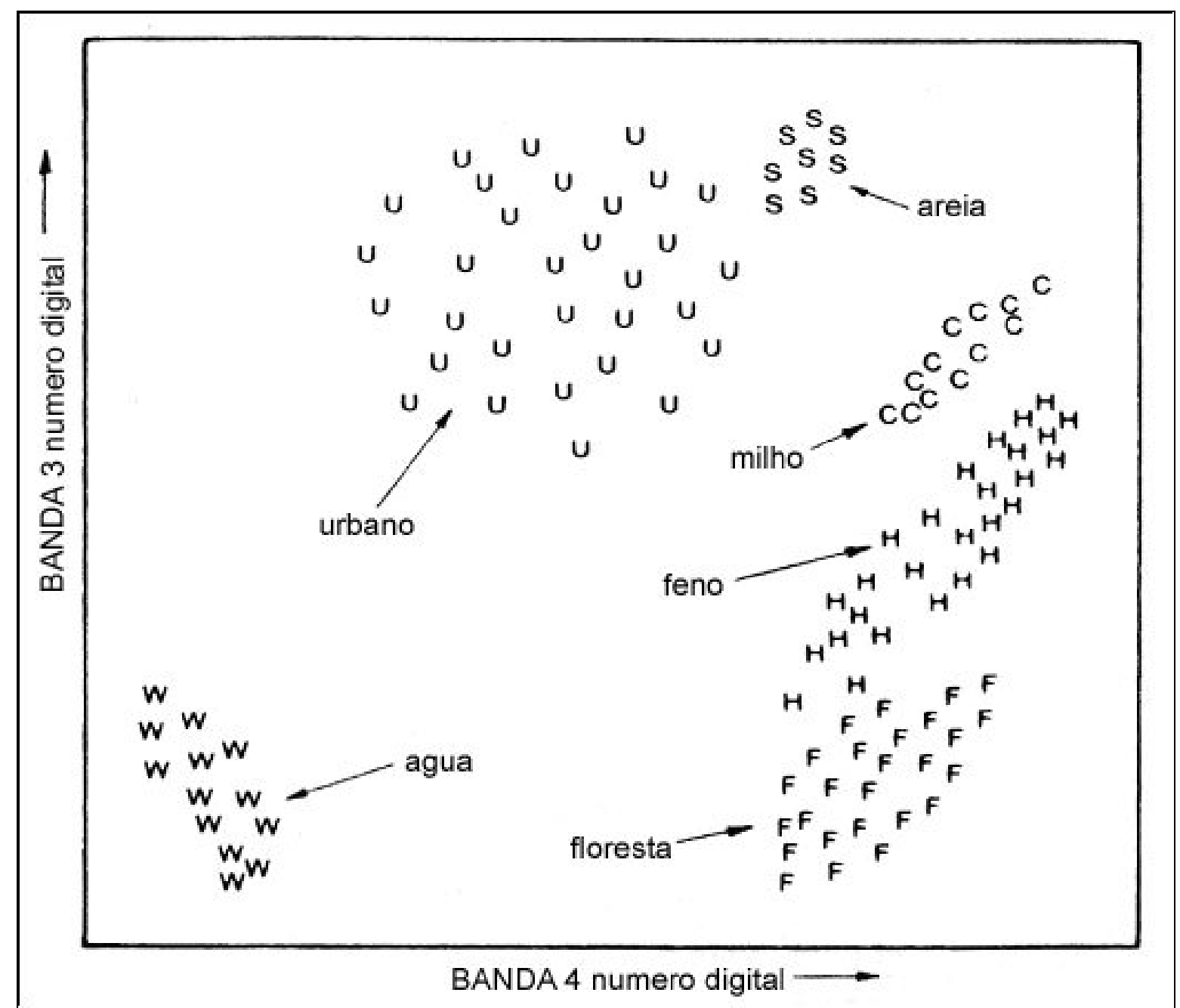

Figura 6 - Ilustração do espaço bidimensional de atributos, com agrupamentos de pixels com padrões espectrais semelhantes. Adaptado de Lillesand, Kiefer e Chipman (2004).

Tomando como referência um pixel, sua classificação será dada em função de regras montadas a partir de medidas realizadas entre a posição do mesmo, no espaço de atributos, e parâmetros extraídos dos agrupamentos existentes ou em formação. Vale lembrar que o processo irá depender da forma com que a classificação estará sendo desenvolvida (supervisionada ou não supervisionada). Em suma, as regras podem ser baseadas em função da distância entre o pixel e o centro (ou borda) das classes, em função da existência de classes que os envolvam, bem como em função da probabilidade do mesmo pertencer aos agrupamentos vizinhos, ilustrados na Figura 7. 


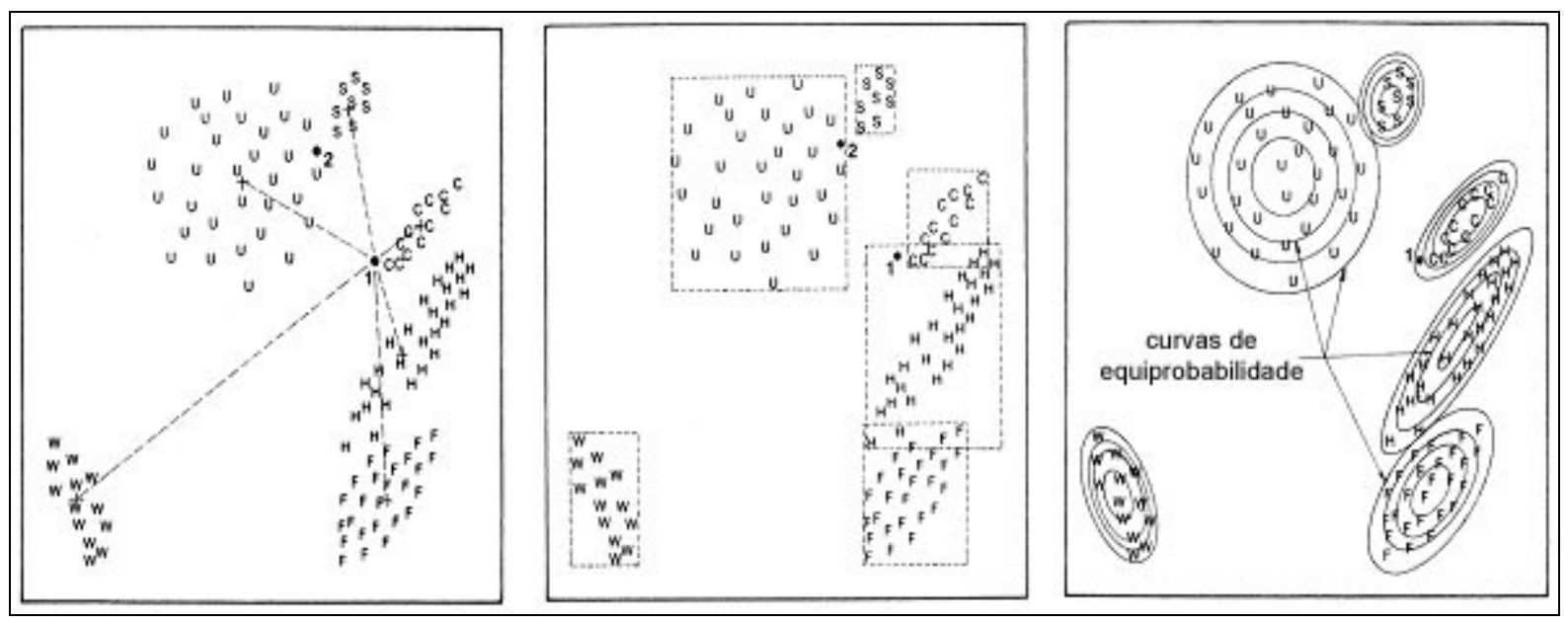

Figura 7 - Estratégias de classificação. Em ordem: Mínima distância da média, paralelepípedo e máxima verossimilhança. Adaptado de Lillesand, Kieffer e Chipman (2004).

O caso mais simples ocorre na classificação baseada na mínima distância entre a representação do elemento no espaço de atributos e a posição média das classes. O elemento passa a ser classificado de acordo com o agrupamento mais próximo. Tso e Mather (2001), entretanto, mencionam que essa medida pode ser através da distância Euclidiana, ou pela distância de Mahalanobis. Enquanto a distância Euclidiana assume variâncias iguais, representando agrupamentos circulares, a distância de Mahalanobis leva em consideração a forma da distribuição de freqüência (assumida ser gaussiana) de um determinado agrupamento no espaço de atributos, podendo, com isso, assumir agrupamentos elipsoidais.

Outra técnica de classificação popular é conhecida por paralelepípedo. $O$ conceito dessa técnica baseia-se na delimitação dos agrupamentos por limiares. Em uma dimensão, analisando o histograma de apenas uma banda, a introdução dos limiares é conhecida como fatiamento. Quando em um espaço bidimensional de atributos, as figuras resultantes formam retângulos e quadrados que englobam os agrupamentos. Analogamente, o paralelepípedo é obtido quando utilizado o espaço tridimensional de atributos. No entanto, espaços n-dimensionais também podem ser analisados por essa técnica.

Segundo Tso e Mather (2001), apesar de simples, o classificador por paralelepípedo considera a variância dos agrupamentos, ou seja, são definidos os limites considerando a amplitude entre os mínimos e máximos valores de cada 
classe. Sua grande vantagem é a facilidade de implementação e velocidade de processamento. Como desvantagem, essa técnica mostra-se ineficiente quando ocorre a sobreposição de duas ou mais classes.

Uma solução mais completa é dada pelo classificador de máxima verossimilhança. Lillesand, Kieffer e Chipman (2004) mencionam que essa técnica avalia quantitativamente ambas a variância e a covariância dos agrupamentos das respostas espectrais quando classifica um pixel desconhecido. Para isso, assumese que a nuvem de pontos representada no espaço de atributos seja gaussiana, ou seja, possui distribuição normal. Com isso, funções de densidade de probabilidade são utilizadas para classificação, pelo cálculo da probabilidade do pixel desconhecido pertencer a cada classe. Em sua essência, o classificador de máxima verossimilhança cria curvas de eqüiprobabilidade elipsoidais no espaço de atributos, (LILLESAND, KIEFFER e CHIPMAN, 2004).

Como principal vantagem, esse classificador pode promover resultados mais refinados que as técnicas anteriores por ponderar a classificação. Entretanto, sua principal desvantagem surge quando utilizada uma quantidade grande de dados, pois a aplicação requer excessivos cálculos computacionais. Esse cenário pode ser facilmente visto quando utilizadas várias bandas espectrais na classificação. Para isso, procura-se empregar técnicas de redução da dimensionalidade dos dados. Maiores detalhes podem ser encontrados em Lillesand, Kieffer e Chipman (2004), Tso e Mather (2001) e Kohn (1998).

\subsection{A PROBLEMÁTICA DOS CLASSIFICADORES TRADICIONAIS PARA IMAGENS DE ALTA RESOLUÇÃO ESPACIAL}

Para Blascke e Strobl (2001), se por um lado o sensoriamento remoto sofreu um enorme progresso nos últimos anos, em termos de aumento de resolução, disponibilidade de dados e de divulgação pública, a grande maioria das aplicações remete a conceitos básicos de processamento de imagens desenvolvidos a partir da 
década de 70: classificações por pixels utilizando o espaço multidimensional de atributos.

Os modelos tradicionais de classificação de imagens recorrem à análise dos valores (números digitais) dos pixels nas bandas espectrais utilizadas. Independente do classificador adotado, as diferentes respostas espectrais atribuídas aos pixels nas diferentes bandas são, em geral, analisadas em conjunto (ou apenas as bandas espectrais mais representativas) utilizando o espaço multidimensional de atributos. Segundo Shackelford e Davis (2003), os esquemas de classificação por pixel visam identificar a classe de cada pixel na imagem através de comparações do vetor $\mathrm{n}$-dimensional de dados de cada elemento com o padrão de cada classe. INPE (2005) menciona que, embora a classificação estatística seja o procedimento convencional mais utilizado para a análise de imagens, constituído por um processo de análise dos pixels de forma isolada, ela apresenta a limitação da análise pontual ser baseada unicamente em atributos espectrais.

No entanto, muitas das feições presentes no cenário urbano, como ruas, edificações e estacionamentos, podem possuir respostas espectrais similares, devido à composição do material. Ademais, os pixels dessas imagens podem conter informações de diversas classes, denominados pixels mistos, embora a natureza das imagens de alta resolução espacial reduza substancialmente esse efeito. Como conseqüência, o emprego de técnicas baseadas somente nas informações pontuais dos pixels promove classes espacialmente descontínuas.

Para Neubert e Meinel (2005), se por um lado o problema de pixels mistos foi reduzido com a introdução de imagens de alta resolução, por outro, aumentou-se fortemente a variabilidade e o ruído interno dentro de classes quase homogêneas. As concepções convencionais de classificação de imagem encontram-se próximas de seus limites. Experimentos realizados por Woodcook e Strahler (1987) mostram que a relação entre a dimensão dos objetos de interesse e a resolução das imagens pode formar um ambiente adequado para a classificação, se devidas proporções forem respeitadas.

Segundo a mesma linha de análise, Huang, Bingfanf e Jinlong (2003) apresentam resultados da análise da relação entre precisão da classificação, escala de segmentação e resolução da imagem de alta resolução espacial em áreas 
urbanas. De forma análoga, os melhores resultados são obtidos quando os objetos de interesse e a resolução da imagem não apresentaram grandes discrepâncias. No entanto, mesmo os melhores resultados mostraram-se aquém das expectativas. Os autores mencionam que a adoção de regras de decisão baseadas no contexto e na topologia dos segmentos gerados poderia proporcionar resultados mais precisos.

Gwynn (2005) sugeriu que a idéia de se trabalhar, exclusivamente, com uma escala espacial otimizada para a classificação de feições de interesse, onde a variância interclasses é maximizada, como descrita em Woodcook e Strahler (1987), pode ser inadequada para imagens de alta resolução espacial. Para isso, o autor, apresenta como principais problemas a alta homogeneidade interclasses e a alta heterogeneidade intraclasses.

Alguns resultados e discussões sobre as limitações do emprego de classificadores pixel a pixel para identificação do padrão de pavimentação das vias na área de estudo podem ser vistos em Quintanilha e Silva (2005).

\subsection{CONSIDERAÇÕES SOBRE CLASSIFICAÇÃO FUZZY}

As decisões tomadas diariamente não são, em grande parte, determinísticas, mas sim caracterizadas por algum grau de incerteza. Um bom exemplo disso são os conceitos 'quente', 'frio', 'bom' ou 'difícil', que contém elementos de subjetividade, indicando que os mesmos não podem ser completamente (ou deterministicamente) especificados. O que é 'quente' para uma pessoa pode ser 'morno' para outra, como ilustrado na Figura 8.

Tso e Mather (2001) descrevem que o problema de incerteza pode ser estendido para a classificação de imagens de sensoriamento remoto. Um número considerável de erros de interpretação atribui-se aos pixels que possuem afinidade com várias classes de informação. Lillesand, Kieffer e Chipman (2004) e Pinilla (1995) mencionam que o emprego de classificadores fuzzy atende a discriminação de pixels mistos, onde, ao contrário dos pixels puros, a resposta espectral é influenciada por mais de uma classe de informação. 


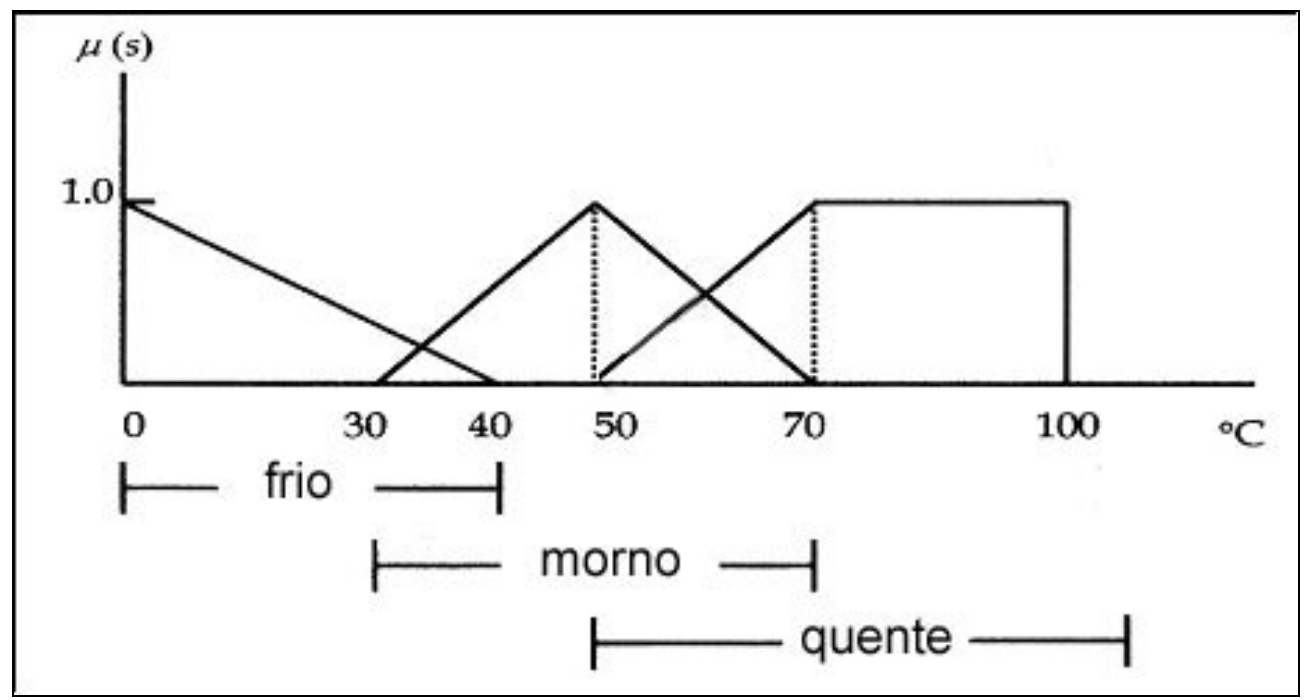

Figura 8 - Partição do espaço em função das classes atribuídas à temperatura, utilizando funções fuzzy de pertinência. Adaptado de Tso e Mather (2001).

A classificação de imagens por lógica fuzzy visa suprir a lacuna deixada por grande parte dos classificadores rígidos, fazendo com que a discriminação dos elementos seja baseada em regras maleáveis. Segundo Baatz et al (2004), a lógica fuzzy pode ser entendida como uma aproximação matemática para quantificar incertezas. A idéia básica é substituir respostas dicotômicas, estritamente lógicas, como "sim" e "não" por um intervalo contínuo de valores [0...1], onde o 0 equivale exatamente ao "não" e o 1 exatamente ao "sim". Valores entre 0 e 1 representam maior ou menor incerteza sobre a classe a ser atribuída.

De forma análoga, os classificadores bayesianos têm como princípio a discriminação dos elementos baseada na variação da probabilidade (BENEDIKTSON, SWAIN e ERSOY, 1990 ; DUDA e HART, 1973 ; JENSEN, 1986 ; KOHN, 1998 ; PINILLA, 1995 ; TSO e MATHER, 2001). Embora os classificadores fuzzy e bayesiano forneçam respostas ponderadas para diferentes pixels, a função de pertinência é montada de forma a atender diferentes propósitos. Lillesand, Kieffer e Chipman (2004) mencionam que a diferença fundamental é que enquanto os classificadores bayesianos utilizam regras de decisão baseadas na variação da probabilidade, para os classificadores fuzzy as regras de decisão são baseadas nas variações de incerteza. No entanto, os vetores das médias fuzzy e as matrizes de 
covariância são obtidos através de dados de treinamento, ponderados estatisticamente.

Nesse contexto, modelar a incerteza, em lógica fuzzy, corresponde a adaptar a função de pertinência mais adequada a situação em questão. A transição entre a máxima e a mínima incerteza é dada segundo funções matemáticas. $\mathrm{Na}$ prática procura-se utilizar funções "puras" como forma de simplificar a modelagem da incerteza. Dependendo da função utilizada, a transição entre 0 e 1 pode ser abrupta (função retangular) ou suave, descritas por Tso e Mather (2001) como funções monotônicas, trapezoidais, triangulares e em forma de sino (gaussianas), representadas na Figura 9.

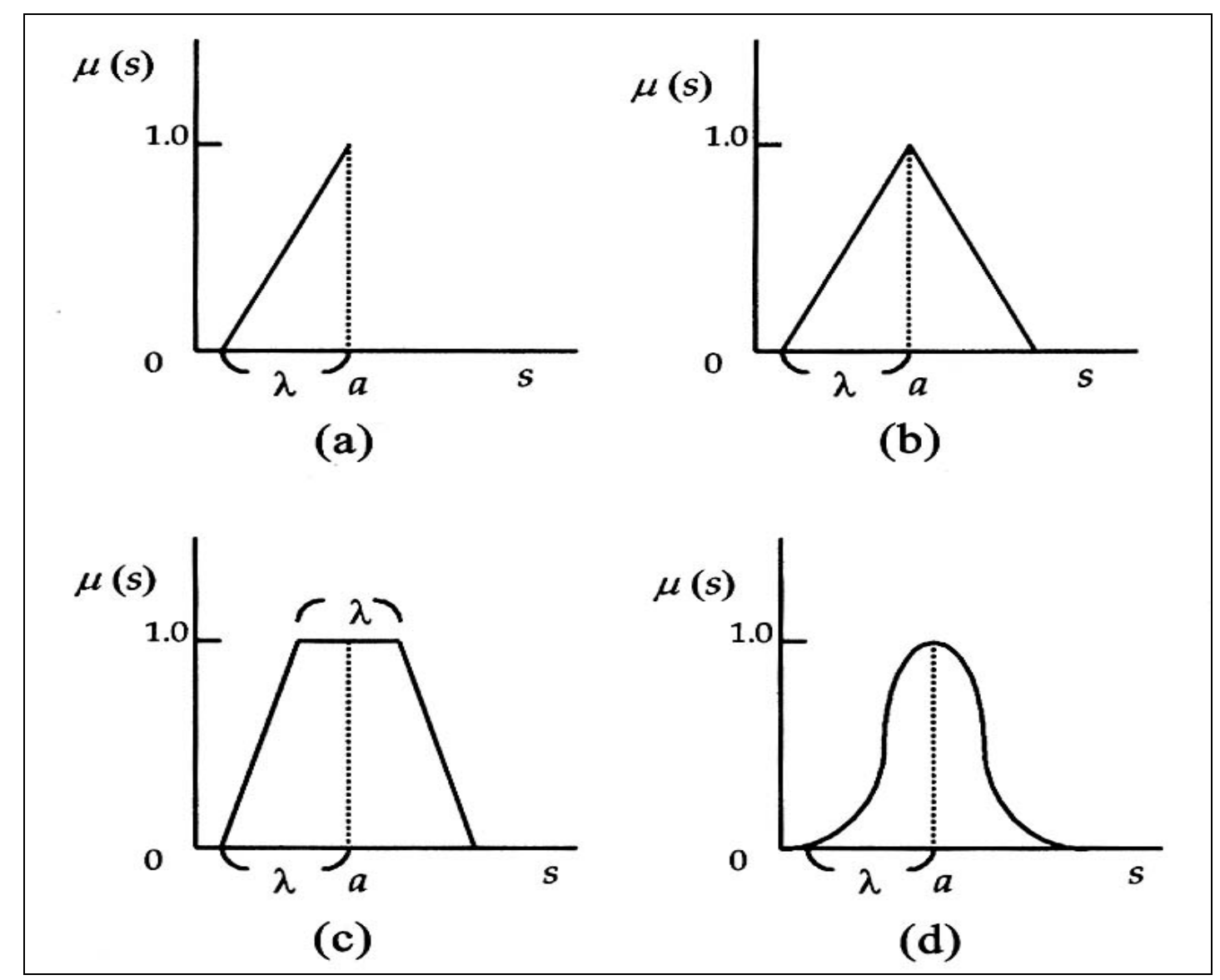

Figura 9 - Funções de pertinência comuns em sistemas fuzzy: a) monotônica, b) triangular, c) trapezoidal e d) gaussiana. (TSO e MATHER, 2001). 
Correspondentemente, as equações das funções de pertinência aplicadas na classificação fuzzy, ilustradas acima como:

Função Monotônica:

$$
\begin{aligned}
& \mu(s)=1-\frac{a-s}{\lambda} \quad \text { para } 0 \leq a-s \leq \lambda ; \\
& \mu(s)=0 \quad \text { em caso contrário. }
\end{aligned}
$$

Função Triangular:

$$
\begin{aligned}
& \mu(s)=1-\frac{|a-s|}{\lambda} \quad \text { para } 0 \leq|a-s| \leq \lambda ; \\
& \mu(s)=0 \quad \text { em caso contrário. }
\end{aligned}
$$

Função Trapezoidal:

$$
\begin{array}{ll}
\mu(s)=\min \left\{2-\frac{2|s-a|}{\lambda}, 1\right\} & \text { para } a-\lambda \leq|s-a| \leq a+\lambda ; \\
\mu(s)=0 & \text { em caso contrário. }
\end{array}
$$

Função Gaussiana:

$$
\begin{aligned}
& \mu(s)=2\left(1-\frac{|s-a|}{\lambda}\right)^{2} \quad \text { para } \frac{\lambda}{2} \leq|s-a| \leq \lambda ; \\
& \mu(s)=1-2\left(1-\frac{|s-a|}{\lambda}\right)^{2} \quad \text { para } 0 \leq|s-a| \leq \frac{\lambda}{2} ;
\end{aligned}
$$

onde:

$\mathrm{S}=$ valor do pixel;

$\mu(s)=$ qualificador da função de pertinência

$\lambda=$ amplitude da função de pertinência

$a=$ centro da função de pertinência. 
Nos sistemas de classificação por fuzzy, ocorrem sobreposições entre diferentes funções de pertinência, em geral em seus valores extremos, cujo grau de incerteza passa a ser maior. No entanto, um elemento cujas propriedades o definem como pertencente à região de sobreposição, passa a ser membro simultaneamente das classes sobrepostas, cada qual com seu grau de incerteza. Os diferentes graus de incerteza atribuídos ao elemento serão utilizados na ponderação final da classificação. Quanto mais ampla for a área de abrangência comum a duas ou mais funções, maior o grau de incerteza a ser atribuído ao elemento.

Do ponto de vista estrutural, o processo de classificação por lógica fuzzy é composto por três etapas. A primeira, denominada fuzzyfication, envolve a divisão do espaço de atributos em subespaços fuzzy, cada qual especificado por sua respectiva função de pertinência. A segunda etapa, denominada inferência, remete a análise e cálculo em conjunto da contribuição das funções de pertinência. Em especial, são analisadas regras condicionais de classificação. Por sua vez, a terceira etapa corresponde à criação de um conjunto discreto de padrões, para os quais os resultados finais da classificação são atribuídos, denominada defuzzification, (TSO e MATHER, 2001). A defuzzyfication pode ser entendida como o processo reverso da fuzzification. A Figura 10 esquematiza esse processo.

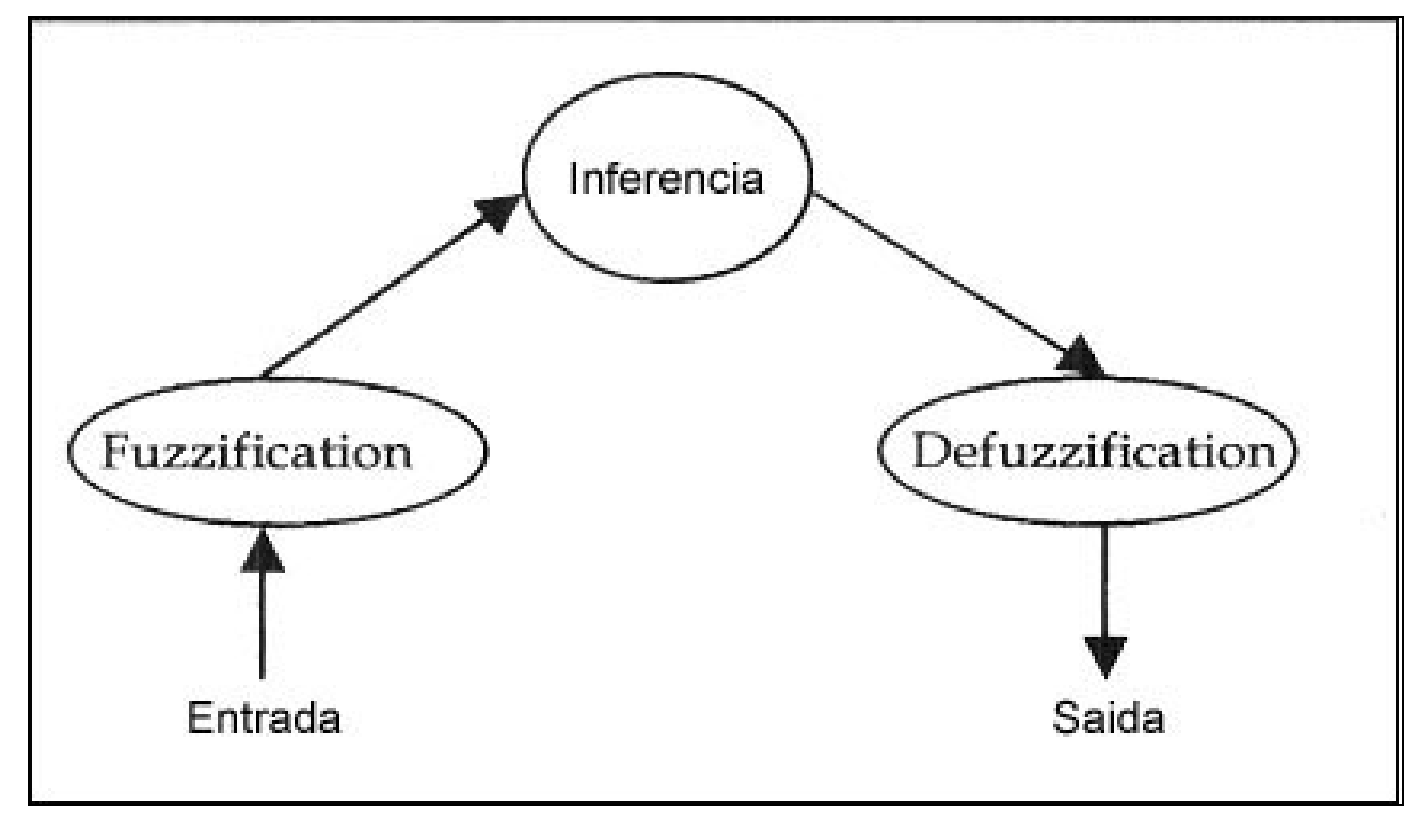

Figura 10 - Arquitetura básica do sistema fuzzy. Adaptado de Tso e Mather (2001). 
Como etapa inicial, a fuzzification é responsável pela transição entre o sistema crisp (rígido, dicotômico) para o sistema fuzzy através de funções de pertinência, adequando o dado a respectiva posição no intervalo entre 0 e 1. Esse processo recorre à função que melhor adapte à representação das propriedades do elemento. Para o sucesso da classificação, a escolha da função de pertinência é fundamental. Quanto maior a base de conhecimento para modelar as funções, melhor o resultado final da classificação.

Autores como Baatz et al (2004) denominam a etapa de inferência como etapa base da regra fuzzy, para a qual são combinadas seqüências de operações lógicas na análise. Operadores como "IF" e "THEN" são utilizados em conjunto com operadores lógicos como "AND" ou "OR". Todavia, em sendo a classificação de imagens uma ferramenta voltada à obtenção de mapas temáticos, as classes devem ser perfeitamente definidas e ilustradas. Para tanto, os graus de incerteza devem, ao final, ceder lugar a valores discretos, correspondentes às categorias finais. Isso ocorre com a defuzzification.

A classificação fuzzy opera com valores de incerteza, que modelados corretamente, fornecem possibilidades (e não probabilidades) de classificação dos elementos (BAATZ et al 2003). Baseado nessa premissa, trabalhos como Antunes, Lingnau e Silva (2003), Centeno et al (2003), Gerke (2002), Leukert (2005), Kressler, Kim e Steinnocher (2003), Neubert e Meinel (2005), Nobrega et al (2006), Nobrega, O'Hara e Quintanilha (2006), O'Hara (2005), Schiewe e Tuefl (2005), Repaka et al (2004), Shackelford e Davis (2003), bem como Mueller, Seal e Kaufmann (2003), modelaram funções de pertinência utilizando, além dos valores médios espectrais extraídos dos objetos, informações contextuais e topológicas.

\subsection{CLASSIFICAÇÃO DE IMAGENS BASEADA EM OBJETOS}

Para Blaschke et al (2005), esta ocorrendo uma grande revolução no processamento digital de dados de sensoriamento remoto devido às elevadas resoluções espaciais que exigem um novo tipo de processamento além da 
observação dos pixels de forma unitária. Ao invés de classificar os pixels individualmente quanto às suas características espectrais, os novos procedimentos consideram a delimitação de objetos com características espectrais (ou radiométricas) homogêneas, como base para o processamento posterior. A classificação passa a contar com informações extraídas desses objetos, como resposta espectral média, variância, dimensões, forma e textura.

Numa outra instância, a classificação passa a ser influenciada não apenas pelas características dos objetos outrora definidas, mas também pelo contexto. As informações contextuais descrevem como um objeto de interesse pode ser afetado pelos objetos vizinhos. Tso e Mather (2001) introduzem a classificação contextual através de uma analogia, associando informações do ambiente ao elemento. Como exemplo, na língua inglesa as palavras iniciadas pela letra 'q' têm maior chance de serem imediatamente sucedidas pela letra ' $u$ ' que pela letra ' $z$ ' ou 'c'. No caso da classificação de uma área agrícola, um pixel rotulado como 'cenoura' tem maior chance de estar rodeado por pixels da mesma classe do que por pixels de classes como 'água' ou 'trigo'. Para os autores, essa habilidade de modelar o contexto pode reduzir a confusão no processo de classificação.

Embora em constante desenvolvimento, a classificação de imagens baseada em objetos tem como base um fluxo determinado de procedimentos, que se inicia, por exemplo, pelo emprego de técnicas de segmentação para a criação dos objetos. Definidos os objetos, extraem-se, indiretamente dos mesmos, informações espectrais e geométricas. Essa gama maior de informações passa a ser modelada considerando, também, informações contextuais, apoiando análises intra-objetos e interobjetos. A Figura 11 ilustra o fluxo dos procedimentos básicos. 


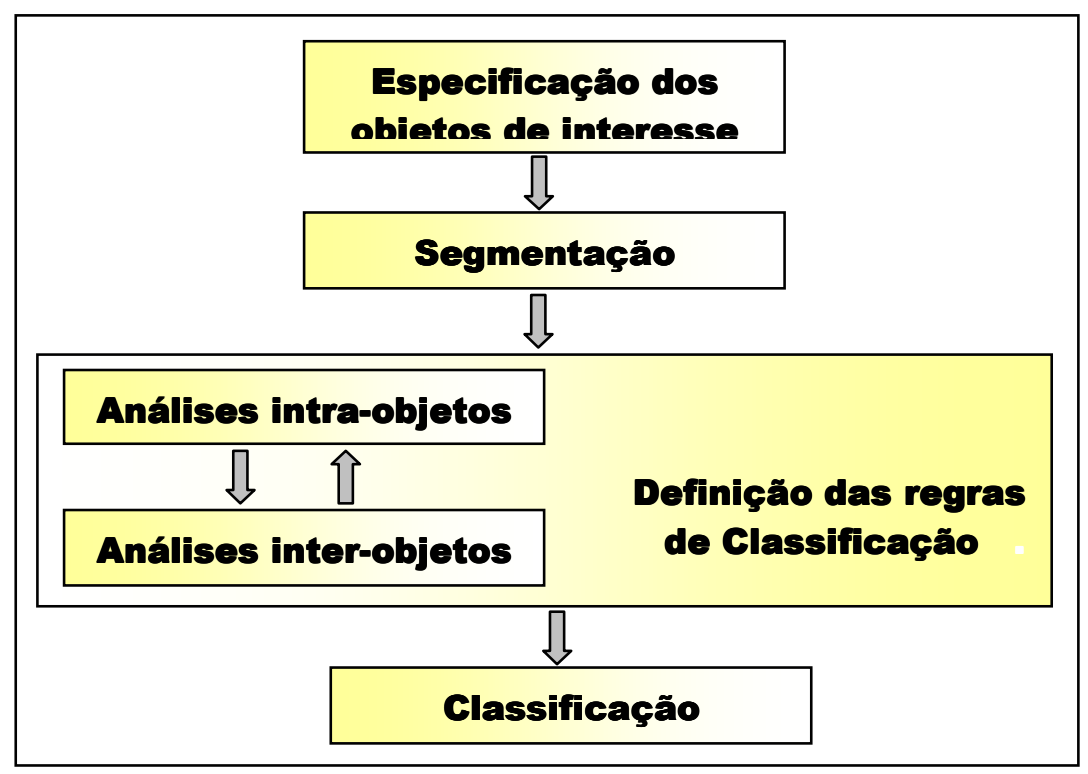

Figura 11- Fluxograma dos procedimentos adotados na classificação baseada em objetos.

Atendo às características particulares de casa objeto, os mesmos podem ser discriminados segundo diferentes médias espectrais, dimensões, formas, coeficientes de compacidade, etc. Embora com respostas espectrais semelhantes uma via com pavimentação de concreto pode, por exemplo, ser separada de uma edificação com cobertura de concreto através de fatores como área e forma. Essa mesma edificação pode ser separada de um estacionamento com pavimentação de concreto (no caso de dimensões semelhantes), por exemplo, recorrendo à análise da vizinhança, ou seja, no relacionamento entre esses objetos de concreto e sua sombra projetada no solo.

Trabalhos como Baltsavias e Gruen (2003), Barnsley, Steel e Baar (2003), Dell'Acqua e Gamba (2002), Ehlers et al (2006), Gerke et al (2001), Schiewe e Tufte (2005), que utilizaram dados altimétricos provenientes de mapeamento por laser aerotransportado - LiDAR (Light Detecting and Ranging), mostraram a eficiência com que diferentes tipos de coberturas e usos do solo urbano podem ser discriminados pela classificação orientada por objetos. Da mesma forma, a introdução de imagens hiperespectrais na discriminação de alvos urbanos, como em Muller, Seal e Kaufmann (2003), pode incrementar, ainda mais, o potencial da classificação baseada em objetos. 
Blaschke et al (2005), Schiewe e Tufte (2005) mencionam que a há uma forte tendência de que classificação baseada em objetos complemente a lacuna entre a extração de informações das imagens de alta resolução e a integração dessas informações num ambiente de SIG. A classificação por objetos não pode ser considerada como um procedimento isolado para a aquisição de informações. A inclusão de regras, cada vez mais complexas, recorrendo a fontes de dados diversas, dados históricos, parâmetros espectrais combinados a parâmetros espaciais, informações topológicas e contextuais, faz com que, mais do que nunca, a classificação passa a depender da supervisão e das tomadas de decisão do operador.

Um exemplo robusto do desenvolvimento de regras de classificação em áreas urbanas, integrando informações de naturezas distintas, pode ser visto em Shackelford e Davis (2003). Nesse trabalho, uma vez constituídos os objetos por segmentação, foram gerados índices referentes à adesão desses objetos às classes especificadas. Os índices foram resultados de análises das respostas espectrais médias dos objetos, das variâncias, das formas (utilizando processo de esqueletonização para análise de ângulos) e das relações para com os objetos vizinhos. Os objetos e os respectivos índices foram inseridos no processo final de classificação utilizando lógica fuzzy.

Nobrega et al (2006) definiram objetos urbanos em imagens do satélite IKONOS II através de segmentação, com o objetivo de discriminar áreas de solo exposto na periferia da cidade de São Paulo. Tomando como base apenas as informações espectrais desses objetos, as áreas de solo exposto apresentaram-se superestimadas, pois muitas edificações com cobertura cerâmica foram detectadas como sendo solo. A introdução de regras de classificação por objetos, considerando descritores como área, forma (ajuste retangular) e vizinhança com sombras permitiu filtrar, em grande parte, as coberturas cerâmicas e reduzir erros de comissão. 


\subsection{DESCRITORES UTILIZADOS NA CLASSIFICAÇÃO BASEADA EM OBJETOS DESTA PESQUISA}

São apresentados neste item os descritores utilizados durante o processo de classificação baseada em objetos. Estes descritores correspondem as propriedades espectrais, geométricas e contextuais que nortearam a separação dos objetos em diferentes classes. Para que possam ser utilizadas na classificação, essas propriedades dos objetos necessitam ser quantificadas para que sejam inseridas nas regras de classificação. Para tanto, são designados descritores, por sua vez alimentados por informações referentes as propriedades previamente mencionadas.

Antunes (2003) apresenta os descritores utilizados em seu trabalho como sendo descritores baseados em valores espectrais e descritores de forma. Adotando semelhante apresentação, os principal descritor baseado em valores espectrais utilizado neste trabalho é a média espectral do objeto, a qual corresponde ao valor médio por banda calculado a partir da somatória dos valores dos pixels pertencentes ao objeto, dividido pelo número de pixels do objeto;

Média espectral do objeto $=C_{L}=\frac{1}{n} \cdot \sum_{i=1}^{n} C_{L i}$

Onde:

$\mathrm{C}_{\mathrm{L}}=$ valor médio calculado

$\mathrm{n}=$ número de pixels do objeto

$\mathrm{C}_{\mathrm{Li}}=$ valor médio do pixel na banda $\mathrm{i}$.

De forma análoga, os descritores baseados na forma do objeto são apresentados abaixo:

- Área: corresponde a área do objeto, contado pela somatória dos pixels internos ao objeto, dado que a resolução espacial aqui é de 1 metro. 
- Comprimento: que corresponde ao comprimento do objeto medido com base em um retângulo envolvente, considerando a rotação dos eixos de acordo com a projeção do eixo principal sobre a linha de maior variância;

$$
\text { comprimento }=L=\sqrt{A \cdot \gamma}
$$

- Largura: corresponde a largura do objeto, medido sobre a largura do retângulo envolvente ao objeto;

$$
\text { largura }=L=\sqrt{A / \gamma}
$$

onde:

$$
\begin{aligned}
& A=\text { área de abrangência do retângulo } \\
& \gamma=\text { razão Comprimento/Largura }
\end{aligned}
$$

- Assimetria: determinada de acordo com a relação entre o semi-eixo maior e o semi-eixo menor de uma elipse que compreende o objeto. Quanto mais longo o objeto, mais assimétrico;

$$
\text { Assimetria }=1-(b / a)
$$

onde:

$$
\begin{aligned}
& a=\text { semi-eixo maior } \\
& b=\text { semi-eixo menor }
\end{aligned}
$$

- Coeficiente de ajuste retangular: calculado através da semelhança entre a forma do objeto e a de um retângulo que se ajuste ao mesmo, considerando uma ponderação no ajuste de forma que a área interna ao retângulo seja igual a área externa. $O$ índice varia entre 0 e 1 , sendo que um objeto retangular apresenta maior índice de ajuste para com o retângulo envolvente. 
Contudo, uma revisão mais detalhada sobre os parâmetros descritores das informações dos objetos pode ser vista em Antunes (2003) e em Baats (2004).

\subsection{CONSIDERAÇÕES SOBRE ESTIMAÇÃO DA ACURÁCIA DA EXTRAÇÃO DE INFORMAÇÕES EM SENSORIAMENTO REMOTO}

Nenhuma classificação de imagens pode ser considerada completa a menos que a acurácia do processo seja fornecida (TSO e MATHER, 2001). Lillesand, Kiefer e Chipman (2004) mencionam que a determinação da acurácia nos processos de classificação de imagens de sensoriamento remoto tem sido alvo contínuo de pesquisas. Essa afirmação passa a ter maior relevância ao se considerar o dinamismo com que as técnicas, sensores e conseqüentemente as aplicações dos dados de sensores remotos têm evoluído.

Congalton (1989) relata que as primeiras aplicações de classificação de imagens orbitais valiam-se do princípio de que a fotointrepretação muitas vezes era considerada corretas e isentas de erros. Ainda, segundo o mesmo autor, no início da década de 80 iniciaram-se os primeiros estudos para avaliação efetiva da acurácia das classificações. Amostras coletadas em campo comprovam a existência de erros, e procedimentos estatísticos de análise foram utilizados para a estimação desses erros. A forma mais comumente utilizada para representar a acurácia da classificação dos dados de sensoriamento remoto utiliza matrizes de erros, conhecida também como matriz de confusão.

A matriz de erros, segundo Congalton (1989), corresponde a uma estrutura quadrada (mesmo número de linhas e de colunas) na qual os dados são ordenados e expressam a quantidade de pixels atribuídos a uma determinada classe. Na matriz de erros, as classes encontram-se dispostas tanto em linhas como em colunas. Lillesand, Kieffer e Chipman (2004) salientam que a matriz de erros compara, classe a classe, o relacionamento entre os dados de referência (amostras verdadeiras coletadas em campo) e o correspondente resultado da classificação automatizada. A matriz de erro é uma forma organizada de representar as acurácias 
de cada, através dos erros de inclusão (erros de comissão) e erros de exclusão (erros de omissão).

No entanto, segundo Laba et al (2002) em processos de classificação apoiados por lógica fuzzy, um mesmo elemento pode estar associado a várias classes simultaneamente, com diferentes graus de pertinência, o que pode levar a um resultado não único. Essa observação gerou certa polêmica sobre a viabilidade do emprego da matriz de confusão. Antunes (2003) propôs a avaliação da classificação baseada no grau de instabilidade, cujo índice é obtido pela proximidade dos graus de pertinência de um objeto entre duas ou mais classes.

Vale ressaltar que a metodologia de detecção das vias proposta neste trabalho não integra a classificação da cobertura do solo da forma tradicional. Classes de interesse foram detectadas e mascaradas do processo, a fim de permitir que outras classes de interesse possam ser detectadas, interativamente, porém sem a presença das informações já mascaradas. Como resultado, o sistema viário (classe única) foi analisado sobre a ótica dos erros de omissão e comissão. Todavia, esses erros foram obtidos computando-se, respectivamente, as ausências e os excessos de informação a partir do cruzamento de planos de informação em um sistema de informação geográfica.

\subsection{ANÁLISE DE CORRESPONDÊNCIA LINEAR}

A análise de correspondência linear em sensoriamento remoto surgiu como forma de estimar a acurácia com que as feições lineares são extraídas. Mais precisamente, o que tem demandado estudos envolvendo análises de exatidão, precisão e qualidade das feições lineares em sistemas de informação geográfica e sensoriamento remoto são as pesquisas relacionadas à detecção e extração de sistema viário. Em geral, detecção e extração das vias estão ligadas à atual demanda quanto à atualização da base de dados do sistema viário.

O presente trabalho segue essa linha de raciocínio e utiliza funções de correspondência entre elementos lineares, como integralidade (ou completeza - 
completeness) e precisão (correctness), entre os elementos lineares extraídos e os elementos lineares de referência, bem como a redundância com que os elementos lineares apresentam. $O$ detalhamento das funções de correspondência linear pode ser acessado em Wiedemann (2003), Wessel e Wiedemann (2003) e Seo e O'Hara (2004).

Em geoprocessamento, a análise de correspondência linear tem sido desenvolvida comparando-se a linha central da via extraída com uma linha central existente em forma vetorial. Em projetos de escala compatíveis a aplicações urbanas emprega-se o eixo de logradouros, normalmente existente e, em projetos de escalas menores a base vetorial do sistema viário. Seo e O'Hara (2004) apresentam os resultados de uma ferramenta (Road Feature Evaluation Toolkit) desenvolvida a partir das principais funções de correspondência linear, e também funções de análise da qualidade da malha viária, visando quantificar medidas capazes de refletir a qualidade das extrações de vias. Seu desenvolvimento foi alavancado pela alta demanda em mapeamentos da rede viária federal norte-americana advinda do Programa TIGER MAP (United States Census of Bureau) do governo norteamericano desde a última década.

A correspondência entre as linhas referenciais e linhas extraídas tem como base a análise do casamento geométrico entre ambas as feições. Essa análise é feita utilizando faixas de abrangência com larguras pré-definidas (buffers), ilustradas na Figura 12. 


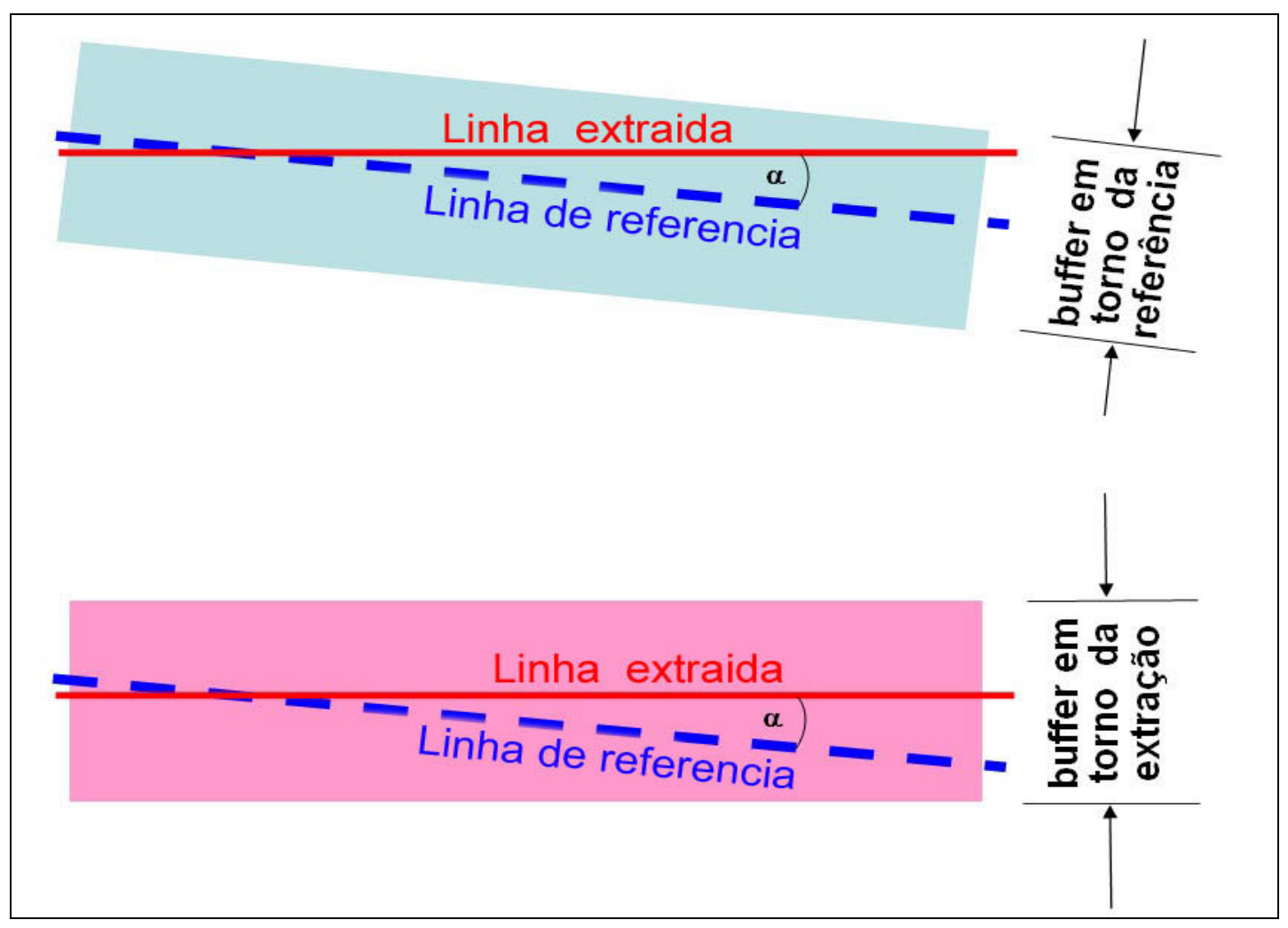

Figura 12 - Princípio da análise de correspondência linear. Acima o casamento com a linha referêncial (zona de referência) e abaixo o casamento com a linha extraída (zona da extração). Adaptado de Wiedemann (2003).

Para Weidemann (2003), quanto maior a tolerância para o casamento entre as linhas, menor o rigor do processo de extração. No entanto, uma tolerância maior desse casamento acaba gerando resultados aparentemente mais precisos e, na prática, menos confiáveis, uma vez que a área de abrangência dos buffers passa a ser aumentada. O emprego de buffers com largura próxima da largura real das vias implica em resultados mais próximos do real.

Os parâmetros básicos utilizados na análise da correspondência linear, descritos por Wiedemann (2003) e Seo e O'Hara (2004) são:

- $\quad$ integridade (completeness): percentual dos dados de referência que podem ser explicados pelos dados extraídos. Em outras palavras, a completeza revela o percentual da rede de referência detectada no processo de extração. $O$ valor ótimo da completeza é $100 \%$. 
integridade = comprimento da linha extraída / comprimento do buffer de referência

- $\quad$ exatidão (correctness): percentual das linhas corretamente extraídas, ou seja, o percentual das linhas extraídas que se encontra de acordo com as linhas referenciais. O valor ótimo da precisão é $100 \%$.

exatidão = comprimento da linha referência / comprimento do buffer da linha extraída

- $\quad$ redundância (redundancy): representa a percentagem das linhas redundantes corretamente extraídas. Em outras palavras, linhas extraídas cujo buffers se sobrepõem. O valor ótimo da redundância é 0 .

exatidão $=$ (buffer linha extraída - buffer linha referência $) /$ buffer linha extraída

Há também outros parâmetros, como qualidade, ordem de distância e lacunas, que nos permitem inferir sobre a qualidade da malha linear extraída. Esses três parâmetros são derivados da integridade e da exatidão e, segundo Wiedemann (2003), não fornecem informações mais significativas do que a integridade e a exatidão. Para Zhang e Couloigner (2006), a integridade e a exatidão, bem como o RMS (Root Mean Square), abrangem significativamente a análise dos resultados da extração da malha viária. 


\section{RECURSOS EMPREGADOS NA PESQUISA}

\section{1 ÁREA DE ESTUDO}

Os trabalhos foram desenvolvidos no extremo norte do município de São

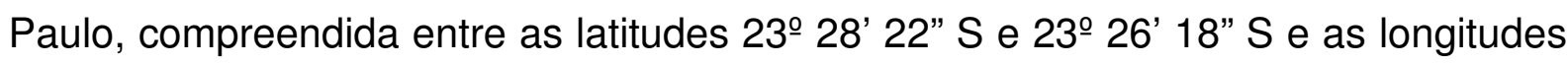
$46^{\circ} 39^{\prime} 05^{\prime \prime} \mathrm{W}$ e 46 42' 29" W, em uma área aproximadamente retangular de 14 $\mathrm{Km}^{2}$, indicada na Figura 13. A região é caracterizada por uma ocupação recente e desorganizada, onde uma ocupação densa encontra-se incrustada numa área preservada de vegetação natural. Essa área é composta por floresta tropical densa e moderada, situada em terreno acidentado, cuja remoção para a introdução da ocupação tem gerado problemas ambientais.

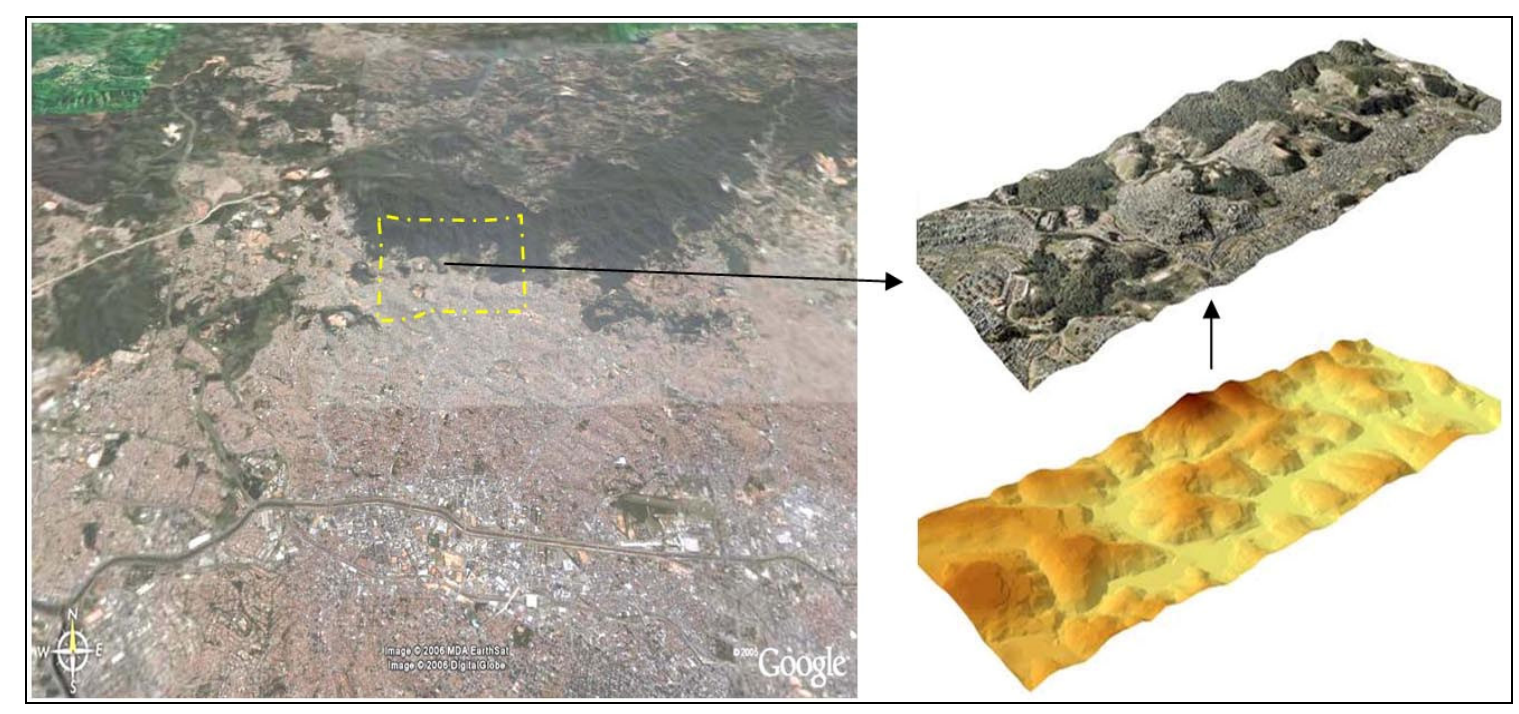

Figura 13 - Vista geral da região norte da cidade de São Paulo, ilustrando a área de estudo e sua topografia acidentada.

Desconsiderando os fatores sociais e econômicos envolvidos, a heterogeneidade da mancha urbana na bacia pode ser notada pelas diferenças no padrão das edificações (aglomeração, dimensão, forma), no sistema viário 
(pavimentação, largura e a não uniformidade no traçado). Grande parte das áreas, localizadas próximas ao limite entre regiões de cobertura florestal e urbana, é tomada por um processo de ocupação irregular. Uma descrição detalhada das características físicas, sociais, bem como o processo de urbanização da região onde se localiza a área de estudo pode ser vista em Barros (2004) e Barros et al (2005).

O número de edificações instaladas nessas áreas aumentou consideravelmente nas últimas décadas, sem seguir um planejamento para comportar tal crescimento urbano. De forma análoga, o sistema viário foi sendo formado de modo a suportar o escoamento da população residente. Verifica-se, com isso, a heterogeneidade com que as ruas têm sido formadas. Outro ponto fundamental a ser considerado é a predominância de um relevo acidentado (descrito em detalhes em NOBREGA, QUINTANILHA e BARROS, 2005), acentuando, ainda mais, as características mencionadas. As características físicas descritas acima podem ser observadas na Figura 14.

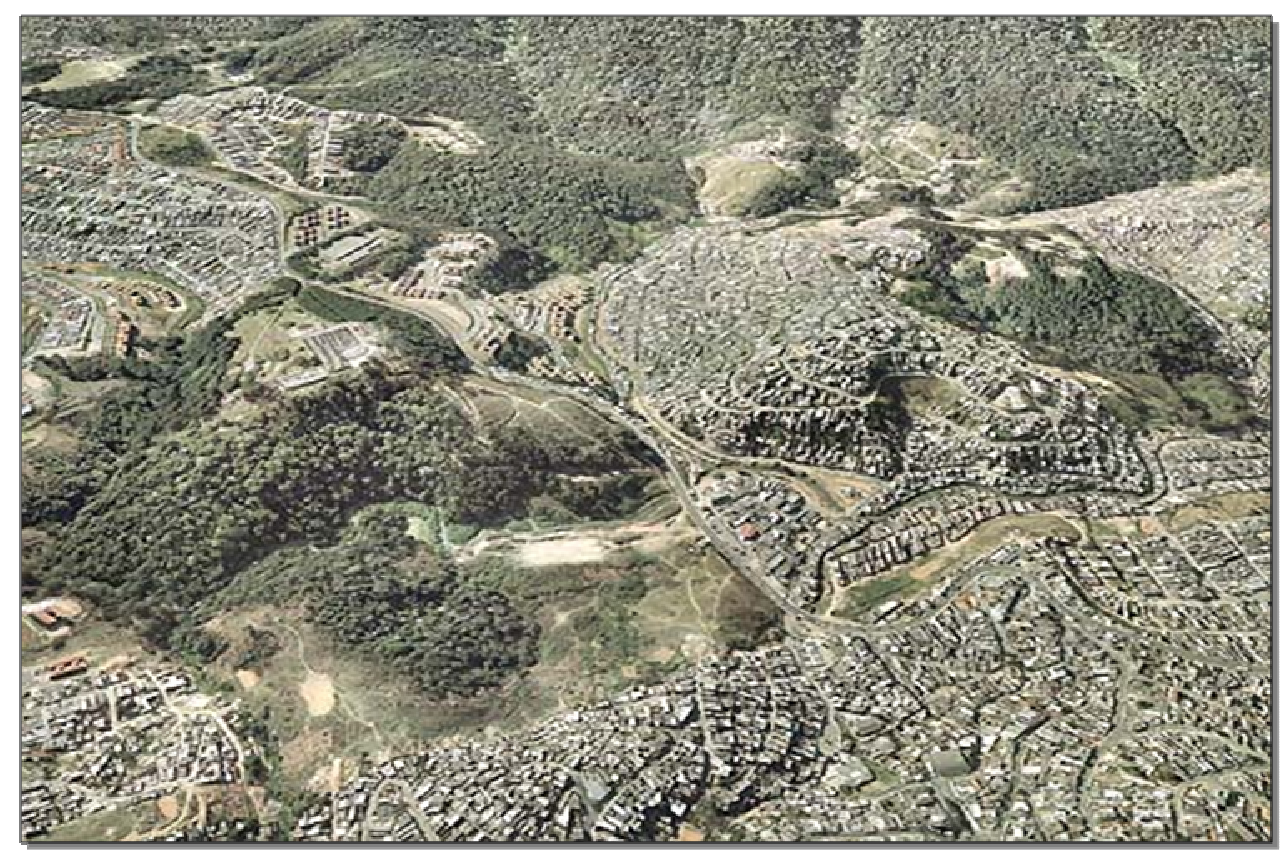

Figura 14 - Vista panorâmica da ocupação irregular das edificações e do sistema viário, em uma região de limite entre a mancha urbana e a área florestal da Serra da Cantareira.

Há ainda a ausência de arborização ao longo das ruas e avenidas em grande parte dessa região. A arborização implantada junto ao sistema viário, em cidades de climas tropical e temperado, é um indicativo utilizado na estimativa da 
qualidade de vida no espaço urbano, e sua ausência reflete, em média, o baixo nível econômico dessa população e a recente urbanização da área. Maiores detalhes podem ser vistos em Alvarez (2004). A realidade retratada pela área de estudo mostra a crescente necessidade de atualizar os mapas de uso de solo, de impactos ambientais e da rede viária, que se assemelha às condições descritas em Repaka et al (2004).

A escolha da área de estudo foi baseada em fatores como a possibilidade de direcionar o projeto de pesquisa à solução (ou ao estudo) de problemas e necessidades urbanas reais, bem como a disponibilidade de dados. Nesse sentido, o presente trabalho passou a ser privilegiado, pelo fato da área de estudo caracterizar grande parte dos problemas viários derivados do crescimento urbano desordenado, que são objetos de estudo deste trabalho. Em outras palavras, a base de informações disponibilizada pelo Projeto Cabuçu de Baixo através do Sistema de Suporte a Decisão para Gerenciamento de Bacia Urbana - SSDURB (Barros, 2004) foi extremamente importante para a adoção dessa área.

\subsection{PROJETO CABUÇU DE BAIXO}

Segundo Barros (2005), a urbanização e a gestão municipal praticamente desfiguraram as pequenas bacias hidrográficas, e, infelizmente, muitos dos problemas existentes nas áreas urbanas advêm da falta de planejamento, e de gestão feitas com base nas bacias hidrográficas. Nesse sentido, o Projeto Cabuçu de Baixo, desenvolvido pelo Departamento de Engenharia Hidráulica da Escola Politécnica da Universidade de São Paulo, visou estudar os problemas relativos à água no meio urbano, tomando como referência a Bacia Hidrográfica do Córrego Cabuçu de Baixo [que compreende a área de estudo], descrita anteriormente, por caracterizar os problemas relativos à água que a cidade enfrenta.

Foram propostos dois projetos voltados às questões da água, sob a ótica da pequena bacia urbana: o primeiro tratando do desenvolvimento de uma ferramenta de planejamento e de gestão urbana, chamada de Sistema de Suporte a 
Decisão para Gerenciamento de Bacia Urbana - SSDURB (Barros, 2004), e o segundo projeto tratando de ações mais específicas, chamado de Plano de Bacia Urbana (Barros, 2005).

Em linhas gerais, o Projeto Cabuçu de Baixo agregou novos planos de informação, na busca pelo entendimento e envolvimento de diferentes setores, para uma modelagem mais consistente dos problemas da Bacia Hidrográfica. No entanto, os primeiros anos desse trabalho geraram materiais ricos em informações de caráter físico, como a base cartográfica em formato digital, mapas de vegetação e de ocupação do solo, mapas de declividade, drenagem, entre outros.

Para a composição desse projeto de pesquisa, a base cartográfica gerada teve um papel fundamental, pois algumas informações, como por exemplo os logradouros (Figura 15), podem ser utilizadas para conferência, ou mesmo para refinar o processamento digital das imagens, mais especificamente o processo de segmentação. Segundo Schiewe e Tufle (2005), uma vez disponíveis os níveis de informação complementares, como limites de lotes ou limites de florestas, esses podem ser utilizados como planos temáticos. Na prática, o que se busca é a reduzir a possibilidade de interpretações errôneas nas regiões onde há a presença de informações antecedentes. Para Leukert (2005), a utilização dessas informações auxilia a interpretação de objetos complexos, podendo integrar relações com objetos adjacentes e objetos internos aos vetores pré-existentes.

Há também um conjunto de ortofotos (Figura 16) abrangendo toda a extensão da bacia hidrográfica e, conseqüentemente recobrindo a área de interesse dessa pesquisa. As ortofotos foram obtidas a partir de fotografias aéreas coloridas, de escala 1:8000, tomadas em Setembro de 2003, cuja finalidade, aqui, passa a ser a verificação e a facilidade de interpretação visual, uma vez que a resolução dos pixels no terreno dessas imagens é de 0,2 metro. Maiores detalhes vide Nóbrega, Quintanilha e Barros (2005). Isso possibilita reconhecer em detalhes as feições que serão extraídas das imagens de satélite de resolução espacial, bem como proceder a verificação final do processo classificatório. 


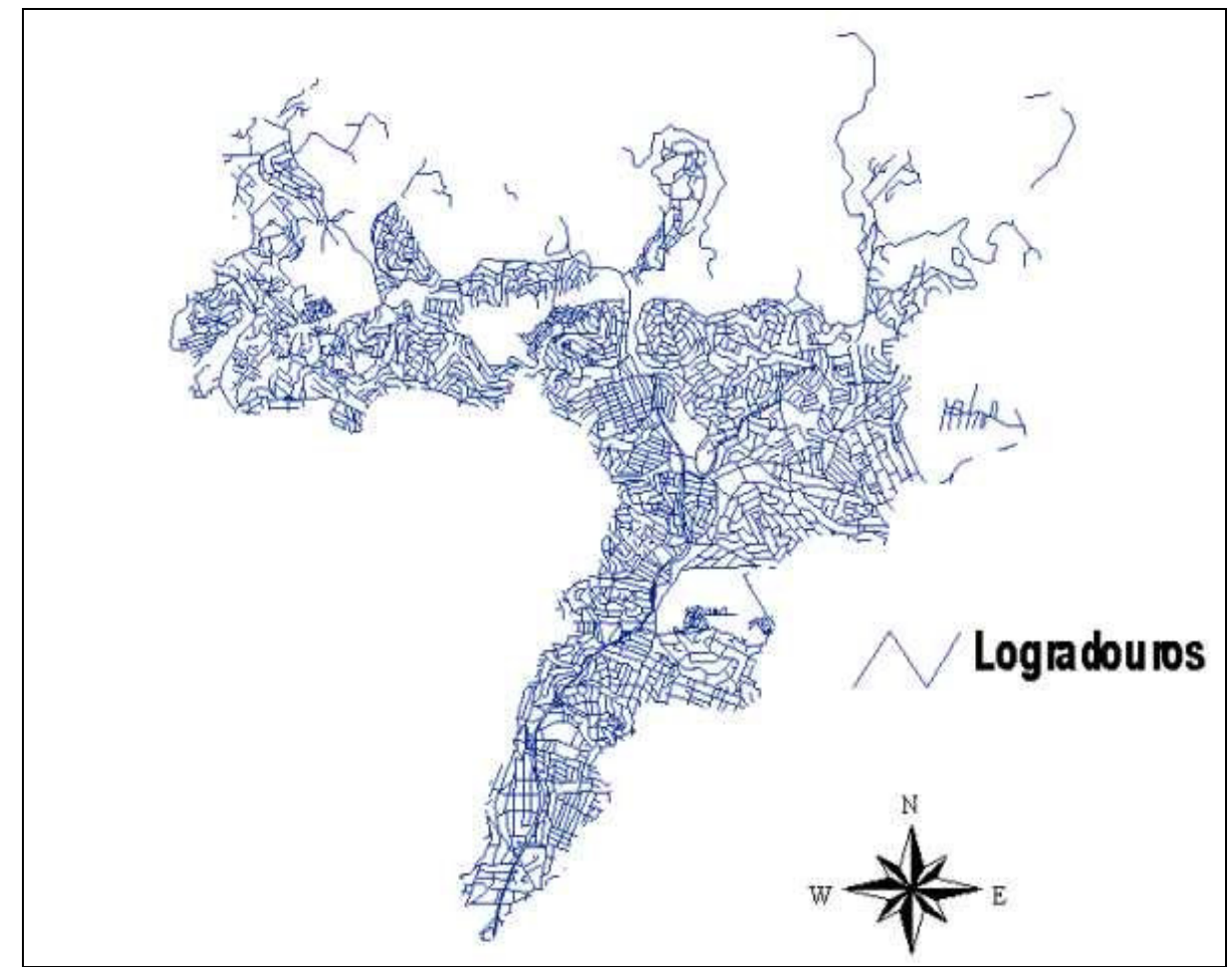

Figura 15 - Plano de informação contendo a base de logradouros (BARROS, 2004).

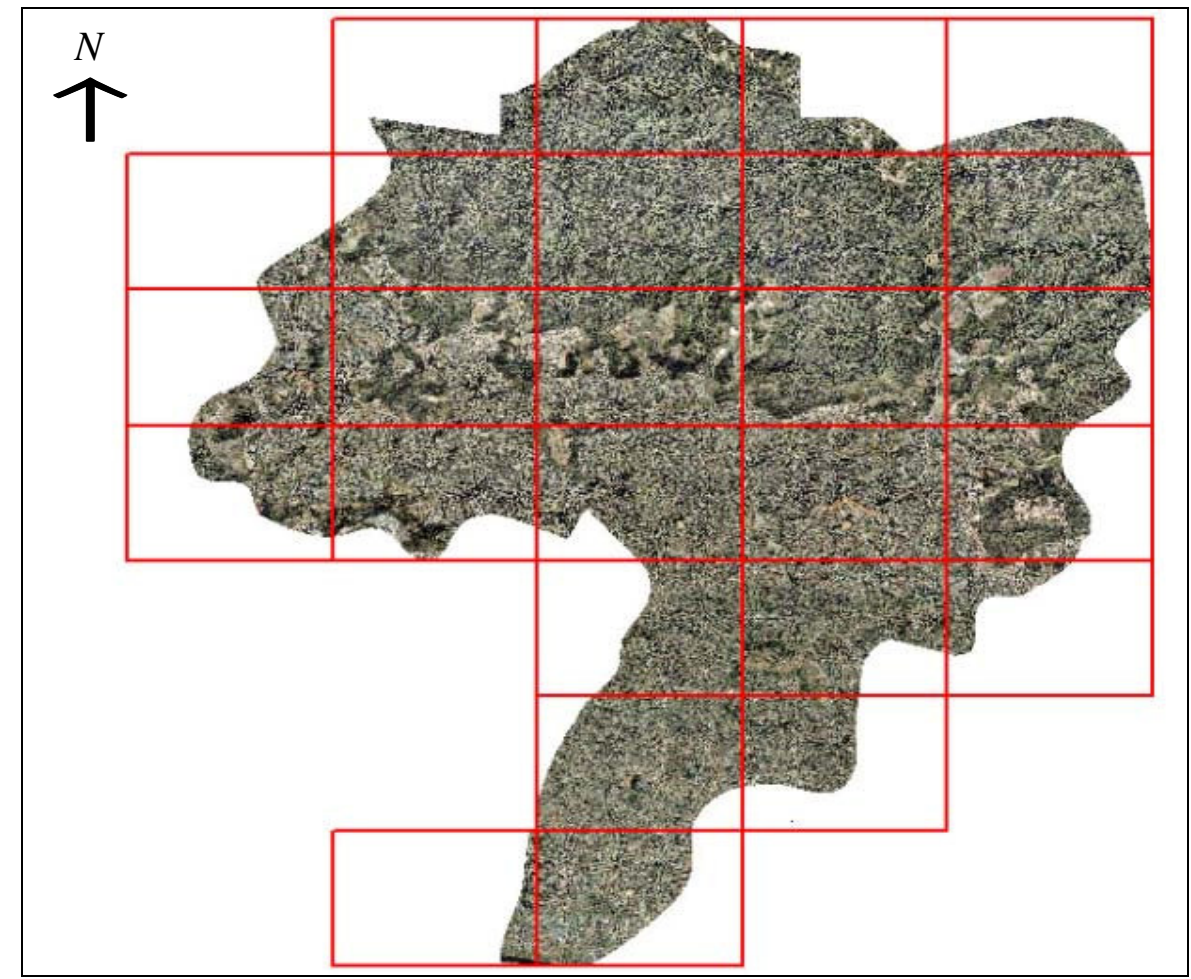

Figura 16 - Articulação das ortofotos disponíveis. 


\subsection{IMAGENS IKONOS II}

Desde seu lançamento, em Setembro de 1999, as imagens do satélite IKONOS II têm sido alvo de intensas análises. Por ter sido o primeiro programa espacial a gerar imagens com resolução espacial na casa de 1 metro, em muitos desses trabalhos, como Baltsavias, Pateraki e Zhang (2001) Jacobsen (2004), Jacobsen (2002) e Dowman (2001), visou-se averiguar a qualidade geométrica de seus produtos. Trabalhos como o de Aplin (2003), Cablk e Minor (2003), Kressler, Kim e Steinnocher (2003) e Koyuncu (2002) utilizam dados radiométricos e espectrais de imagens IKONOS II como objeto de análise.

O satélite IKONOS II captura imagens pancromática $(0,45-0,90 \mu \mathrm{m}) \mathrm{com}$ um metro de resolução espacial e multiespectral com quatro metros de resolução espacial. A imagem multiespectral é composta por 4 faixas distintas do espectro eletromagnético, conforme ilustra a Figura 17, abrangendo comprimentos de onda da porção azul $(0,45-0,52 \mu \mathrm{m})$, verde $(0, .52-0,60 \mu \mathrm{m})$, vermelho $(0,63-0, .69 \mu \mathrm{m})$ e infravermelho próximo $(0,76-0, .90 \mu \mathrm{m})$. Uma descrição detalhada das características do satélite IKONOS II e das imagens por ele geradas podem ser encontradas em Toutin e Cheng (2000), Gruen (2000) e Gupta (2002).

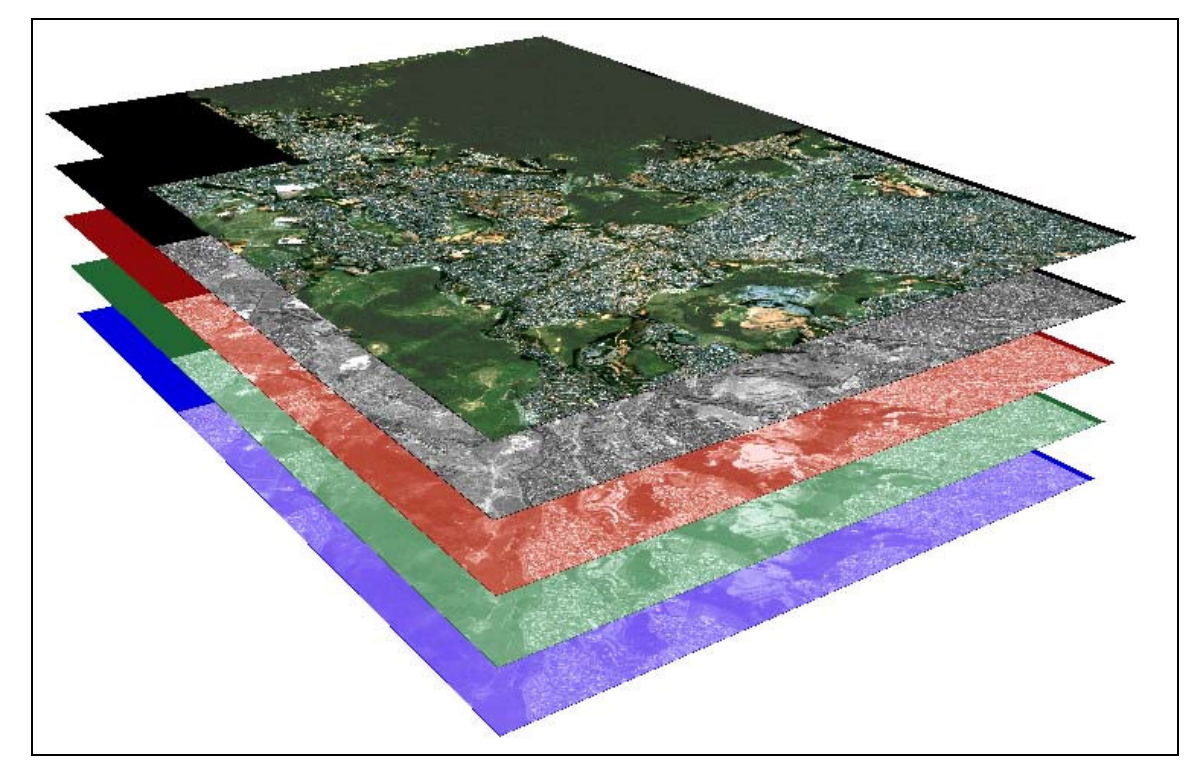

Figura 17 - Imagem do satélite IKONOS II da área do projeto, decomposta pelas quatro bandas espectrais que a compõem. De baixo para cima: azul, verde, vermelho e infravermelho próximo. 
Embora o Projeto Cabuçu de Baixo tenha disponibilizado imagens do satélite IKONOS II, optou-se pelo emprego de imagens adquiridas pelo Instituto Geológico da Secretaria do Meio Ambiente do Estado de São Paulo, por tratar de uma coleção mais abrangente, dados mais recentes e geometricamente mais refinados. O imageamento original data de outubro de 2002 e a abrangência dessa coleção de imagens inclui os 39 municípios da Região Metropolitana de São Paulo (Figura 18). Embora restrita à área selecionada para a pesquisa, a vasta extensão da área de cobertura permite que a metodologia aqui apresentada possa ser executada e avaliada em outras localidades.

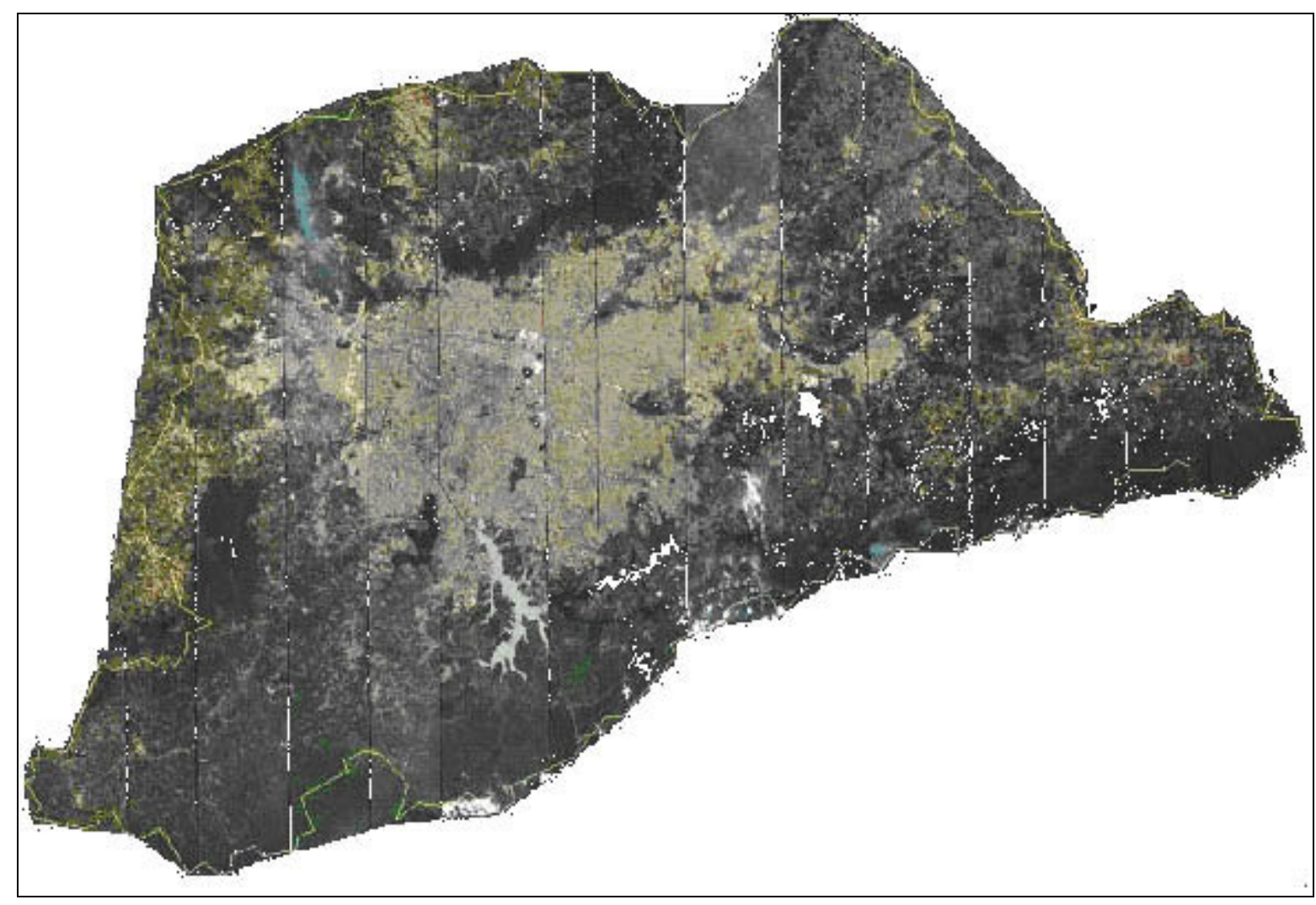

Figura 18 - Cobertura das imagens IKONOS II do Instituto Geológico da Secretaria do Meio Ambiente do Estado de São Paulo. FUNCATE (2004).

As imagens disponibilizadas, e utilizadas nessa pesquisa, são produtos CARTERRA Ortho Precision, obtidos a partir de um preciso modelo digital de terreno. Em outras palavras, essas imagens são derivadas das imagens IKONOS II originais, as quais sofrem uma série de processamentos como a fusão entre bandas 
e a ortoretificação, e correspondem ao mais nobre padrão de imagens oferecido pela Space Imaging LLC. Em primeira instância, os produtos CARTERRA são elaborados a partir da fusão da banda pancromática e de combinações coloridas das bandas NIR, Red, Green e Blue, para a composição da cena multiespectral com resolução espacial de 1 metro. Posteriormente, a imagem multiespectral é ortoretificada, preferencialmente tomando como base um modelo digital de terreno preciso. Esse processamento eleva a exatidão posicional de uma imagem IIKONOS original de 25 metros (CE 90\%) para 4 metros (CE 90\%). Maiores detalhes podem ser vistos em Baltsavias et al (2001) e FUNCATE (2004).

Vale ressaltar que as imagens CARTERRA do Instituto Geológico da Secretaria do Meio Ambiente do Estado de São Paulo foram compiladas utilizando um modelo digital de terreno extraído de cartas em escala 1:10.000 da EMPLASA (Empresa Paulista de Planejamento Metropolitano S.A.). Esse dado altimétrico foi empregado pela Space Imaging LLC no processamento das imagens finais. Desta forma, é prudente afirmar que o produto CARTERRA PRECISION originado não deve ser designado para atender propósitos que almejem escalas maiores que $1: 10.000$.

Embora as imagens IKONOS permitam observar detalhes em escalas maiores que as usuais do planejamento urbano (1:5.000 e 1:10.000), a natureza geométrica de sua geometria de visada é um fator fundamental para evitar o uso irregular dessas imagens como base cartográfica cadastral. Esse trabalho não visa discutir métricas sobre a qualidade geométrica dessas imagens em relação a escala de trabalho, mas sim desenvolver uma metodologia de emprego das mesmas para suprir uma deficiência do monitoramento do espaço urbano em uma escala 1:10.000, compatível a escala utilizada no planejamento urbano.

\subsection{O PROGRAMA ERDAS IMAGINE}

Ao considerar a necessidade de preparar e compatibilizar as imagens a serem trabalhadas na pesquisa, é necessário o uso de uma ferramenta robusta e 
que disponha de tais recursos. A introdução do Erdas Imagine 8.7 viabilizou, em primeira instância o empilhamento das bandas espectrais das imagens IKONOS II e, posteriormente, a mosaicagem das imagens, para recobrir a área de interesse do projeto e o recorte da área de interesse. Ainda, foram utilizados recursos de transformações entre diferentes sistemas de coordenadas, visando compatibilizar o mosaico multiespectral então produzido para o posterior processo de classificação orientada por objetos e os dados disponíveis do Projeto Cabuçu de Baixo.

Mesmo sendo o Erdas Imagine amplamente conhecido e utilizado pela comunidade de sensoriamento remoto, inclusive para a classificação de imagens, a classificação baseada em objetos, como proposta nessa pesquisa, nele não é contemplada.

\subsection{O PROGRAMA ECOGNITION}

Em virtude da crescente oferta de imagens com resoluções mais apuradas e, conseqüentemente, da crescente demanda por novas ferramentas capazes de processá-las, o programa eCognition foi desenvolvido pela empresa alemã Definiens-Imaging $\mathrm{GmbH}$, em meados de 2000. O programa tem como base a segmentação da imagem recorrendo a diferentes resoluções, processo denominado segmentação por multiresolução. Desta forma, os segmentos são criados em níveis de informação distintos, na tentativa de envolver tanto os pequenos detalhes presentes na cena, como as feições macro, utilizadas posteriormente para apoiar a descrição do contexto.

Paralelamente a criação dos segmentos, o aplicativo gera um banco de dados, no qual são armazenadas informações calculadas desses segmentos, desde valores de média, máximos e mínimos de brilho do conjunto de pixels que compõem os segmentos, até parâmetros extraídos da geometria (forma, área) e textura. Nessa arquitetura, as operações passam a utilizar as informações desse banco de dados e não mais dos segmentos diretamente, o que fornece mais agilidade para as 
análises. A descrição detalhada do uso de segmentação em resoluções diferenciadas pode ser visto em Baatz e Schäpe (2001) e Baatz et al (2004).

Desde seu surgimento, o eCognition tem sido amplamente empregado no intuito de ampliar a gama de informações utilizadas para a classificação de imagens em sensoriamento remoto, em especial, empregando imagens de satélites de alta resolução espacial e de aerofotogrametria. Com uma quantidade maior de informações e, dispondo de uma ferramenta que possibilite que o operador trabalhe com essas informações de maneira apropriada, os resultados obtidos a partir do uso do eCognition têm mostrado significativos avanços quanto à precisão da classificação.

Uma vez que o Laboratório de Geoprocessamento de Escola Politécnica da Universidade de São Paulo não possui o aplicativo, buscou-se o apoio de um instituto com disponibilidade e experiência em classificação de imagens baseada em objetos. Nesse sentido, o projeto de pesquisa foi, por 12 meses, desenvolvido junto ao GeoResources Institute da Mississippi State University, sob co-orientação do Dr. Charles G. O'Hara. Todo o processo de classificação foi desenvolvido utilizando o Definiens' eCognition versão 5.0 .

Todavia, vale ressaltar que o processo de classificação baseada em objetos, embora com avanços promissores, tem se mostrado plenamente dependente do conhecimento do operador, seja para caracterização dos objetos através da segmentação das imagens, ou para modelar as regras utilizadas na discriminação dos mesmos, tanto para trabalhos baseados no eCognition, como para os que recorreram à implementação da ferramenta.

\subsection{LINEAR FEATURE COMPATIVE ANALYSIS TOOLKIT-LCAT}

A análise dos primeiros resultados da extração do sistema viário, tomando como base erros de omissão e comissão pareceu, a primeira vista, atender as necessidades propostas na pesquisa. No entanto, considerando esses erros como medições de pixels sobre polígonos de pequena dimensão (vias), tornou evidente a 
necessidade de avaliar a acurácia da classificação a partir de elementos lineares e não a partir de polígonos. Para tanto, foi utilizada a ferramenta L-CAT (Linear Feature Comparative Analysis Toobox, SEO e O'HARA, 2004) que, mesmo em desenvolvimento, fora gentilmente cedida pelo GeoResources Institute da Mississippi State University para apoiar o desenvolvimento dessa pesquisa.

Frente ao crescente incentivo para atualização e manutenção da base cartográfica viária norte-americana, a proposta do L-CAT é fornecer parâmetros quantitativos para avaliar a correspondência entre rodovias extraídas manual ou automaticamente a partir de imagens de imagens e os mapas viários existentes.

Uma vez importadas para o ambiente do L-CAT, a comparação entre a malha de referência e a malha extraída é baseada na interseção de zonas (buffers) no entorno das linhas. Essa comparação prove subsídios para o calculo de parâmetros de correspondência linear, descritos no item 2.11. No L-CAT são computados 6 parâmetros: integridade, exatidão, qualidade, redundância, medidas de distância, e medidas de lacunas, conforme descritas em Seo e O'Hara (2004).

\subsection{MATLAB}

Em sendo uma plataforma de desenvolvimento e compilação de rotinas matemáticas para apoiar a implementação de soluções, o Matlab foi utilizado nesse trabalho pela necessidade de desenvolver rotinas de processamento digital de imagens para adequar o produto, resultante da classificação baseada em objetos, aos padrões lineares necessários para a análise através do L-CAT.

Em suma, os recursos de morfologia de imagens, presentes nas ferramentas (toolbox) de processamento de imagens do Matlab, permitiram o afinamento dos polígonos resultantes das vias extraídas na classificação orientada por objetos, até que a largura de um pixel fosse atingida. Para isso, utilizou-se o comando BWMORPH e 'THIN'. Ainda, após gerar as linhas centrais das vias, uma filtragem de ruídos, ao longo dessas linhas, foi realizada utilizando o comando BWMORPH e 'SPUR'. 
A adesão do Matlab fez-se viável devido à disponibilidade das funções de morfologia de imagens requeridas, e pela compatibilidade com o ambiente do aplicativo L-CAT, desenvolvido e executado sobre a plataforma do Matlab. Maiores detalhes sobre o sistema Matlab e suas ferramentas de morfologia de imagens podem ser encontrados em Gonzales et al (2004) e McAndrew (2004). 


\section{METODOLOGIA}

O desenvolvimento da detecção da malha viária da periferia urbana a partir de imagens multispectrais de alta resolução espacial recorreu a diferentes etapas em sua fase inicial. Essas etapas iniciais cobrem desde a preparação das imagens (empilhamento das bandas espectrais, mosaicagem, recorte $\mathrm{e}$ compatibilização entre diferentes sistemas de coordenadas), até a extração de informações adicionais, como as componentes principais e a própria segmentação, que deram suporte a metodologia de classificação orientada a objetos.

Nesse capítulo são descritos os procedimentos utilizados em cada etapa do desenvolvimento do trabalho. A Figura 19 sintetiza um fluxograma dos principais passos seguidos.

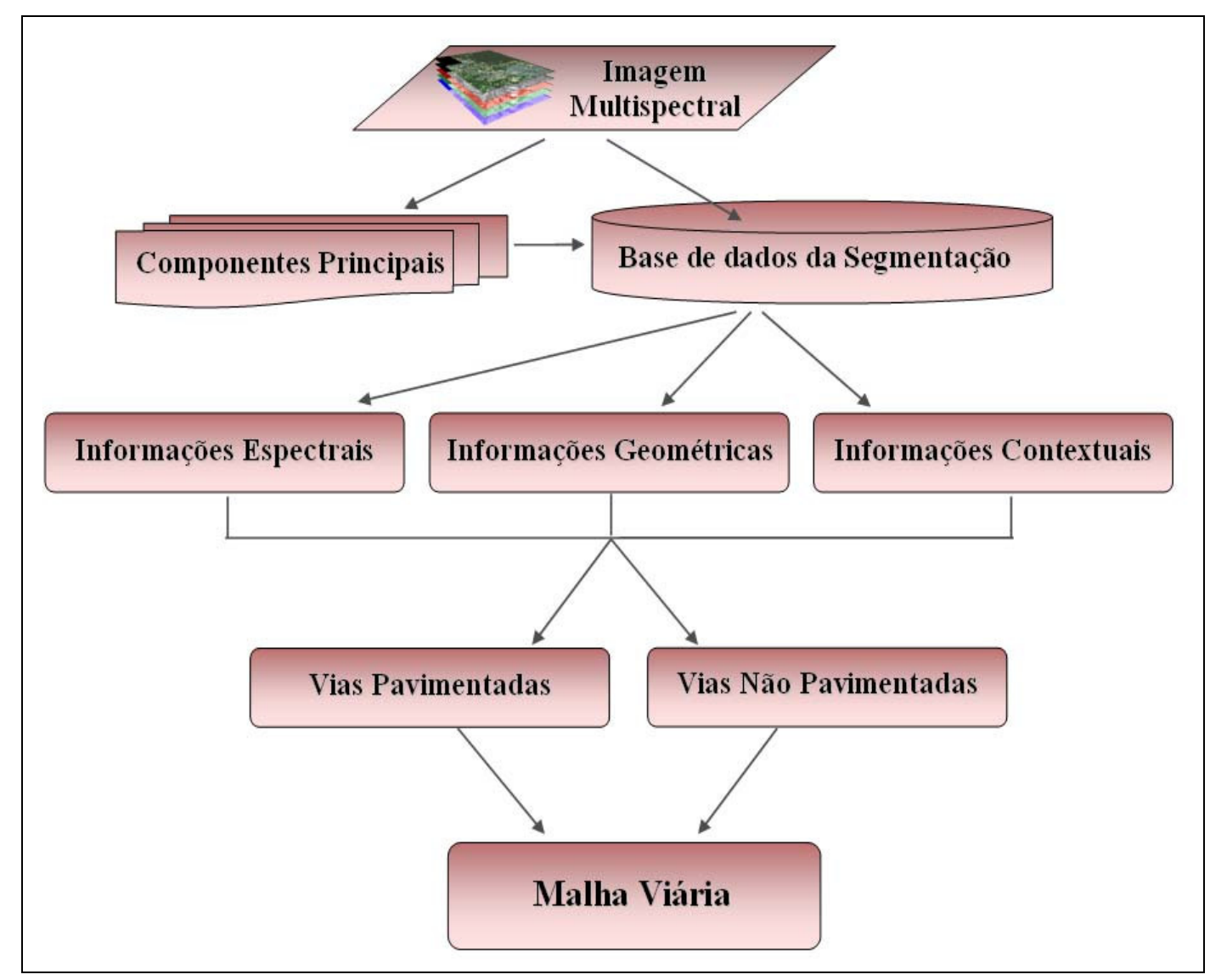

Figura 19 - Fluxograma das etapas proposto na metodologia. 


\subsection{COMPATIBILIZAÇÃO DOS DADOS}

O passo inicial foi a preparação das imagens IKONOS II e compatibilização com os demais dados utilizados no trabalho. A coleção de imagens do Instituto Geológico da Secretaria do Meio Ambiente do Estado de São Paulo recobre toda a Região Metropolitana de São Paulo. No entanto as imagens encontram-se originalmente divididas segundo uma articulação de folhas, conforme ilustra a Figura 20. Ademais, cada folha possui 4 imagens independentes, sendo uma para cada banda espectral. Sobrepondo a área de estudo e a articulação das folhas, as imagens de interesse puderam ser selecionadas. Para cada folha, foram então selecionadas as quatro imagens correspondentes às bandas espectrais azul, verde, vermelho e infravermelho próximo.

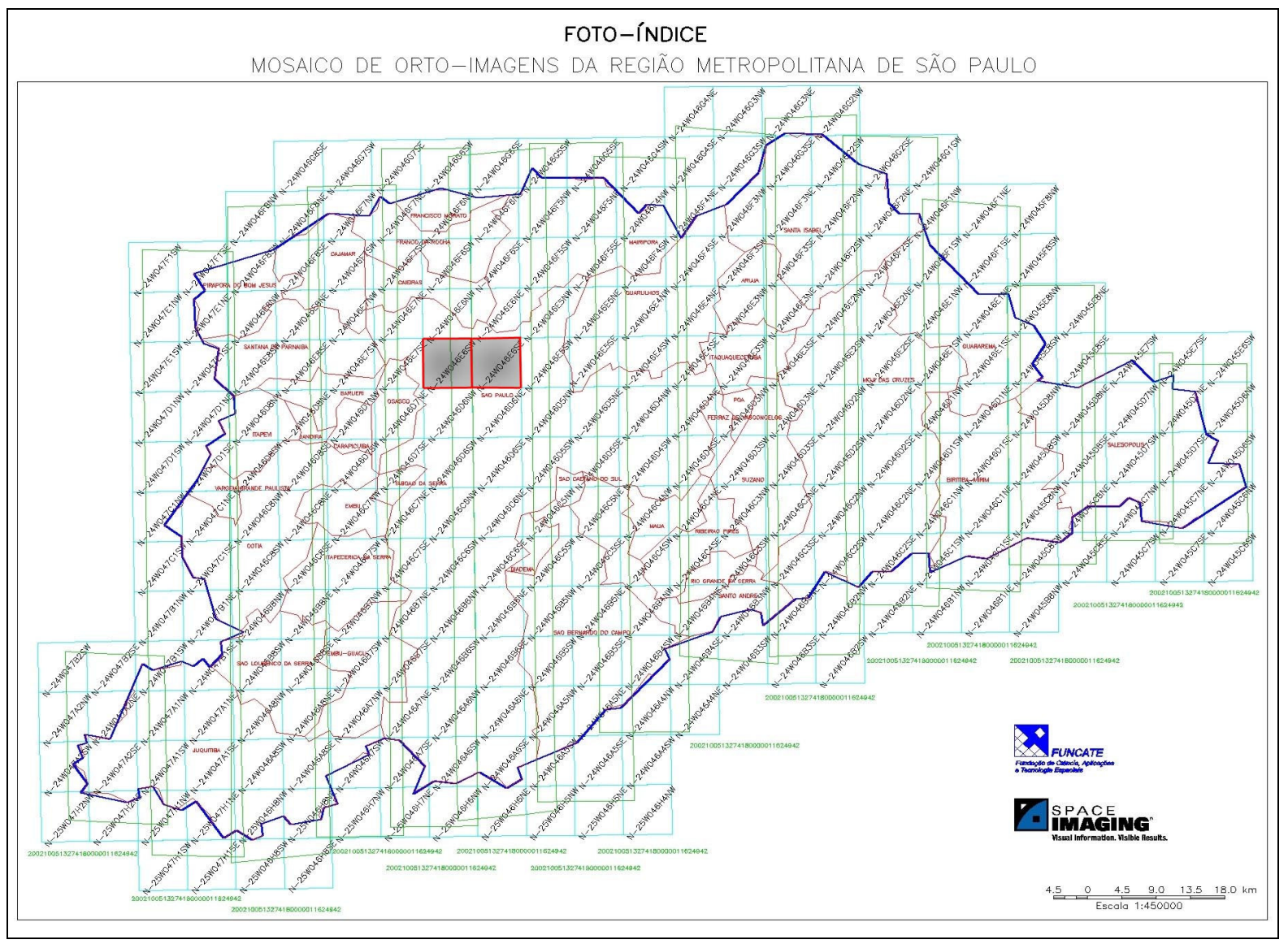

Figura 20 - Articulação das folhas disponíveis sobre a Região Metropolitana de São Paulo e as respectivas informações de órbita e data de captura das imagens IKONOS II. Em destaque, as folhas cujas imagens foram utilizadas nesse trabalho. FUNCATE (2004). 


\subsubsection{Composição das imagens multispectrais}

Partindo do princípio de que o processo de classificação poderia ser melhor desenvolvido ser considerada uma imagem multiespectral de que imagens independentes por banda, a primeira operação realizada foi o empilhamento das imagens correspondentes as bandas em uma imagem multiespectral de 4 bandas. Esse processo foi realizado no programa Erdas Imagine, utilizando a ferramenta LAYER STACK. Foi mantida como padrão a ordem do empilhamento das bandas apresentada na Tabela 3. Esse procedimento foi repetido de forma idêntica para as duas folhas selecionadas, recobrimento assim toda a área de estudo.

Tabela 3 - Arquivos correspondentes às bandas das imagens IKONOS II disponibilizadas e a respectiva ordem de empilhamento para a composição da imagem multiespectral.

\begin{tabular}{l|c|c|c}
\hline \multicolumn{1}{c|}{ ARQUIVO } & $\begin{array}{c}\text { ORDEM DO } \\
\text { EMPILHAMENTO }\end{array}$ & BANDA ESPECTRAL & $\begin{array}{c}\text { IMAGEM } \\
\text { RESULTANTE }\end{array}$ \\
\hline N24W046E56SW_NIR.TIF & camada 1 & Infraverm. próx. (NIR) & \\
N24W046E56SW_RED.TIF & camada 2 & vermelho (R) & N24W046E56SW.TIF \\
N24W046E56SW_GRN.TIF & camada 3 & verde (G) & \\
N24W046E56SW_BLU.TIF & camada 4 & azul (B) & \\
\hline N24W046E56SE_NIR.TIF & camada 1 & Infraverm. próx. (NIR) & \\
N24W046E56SE_RED.TIF & camada 2 & vermelho (R) & N24W046E56SE.TIF \\
N24W046E56SE_GRN.TIF & camada 3 & verde (G) & \\
N24W046E56SE_BLU.TIF & camada 4 & azul (B) & \\
\hline
\end{tabular}

\subsubsection{Mosaicagem}

Visando obter uma imagem que recobrisse a região de interesse, foi necessário unir as folhas N24W046E56SW e N24W046E56SE (indicadas anteriormente na Figura 20) em uma única imagem, ilustrada na Figura 21. As características geométricas dos produtos CARTERRA ORTHO PRECISION, por se 
tratar de imagens ortoretificadas, conforme descrito no capítulo anterior, foram responsáveis pela suavidade e continuidade na junção das imagens.

A mosaicagem foi também realizada no programa Erdas Imagine, utilizando a ferramenta MOSAIC TOOL. Foi adotada a opção de ajuste radiométrico (MATCHING METHOD: FOR ALL IMAGES), como forma de balancear as diferenças de tonalidade e contraste das duas imagens e promover uma imagem resultante radiometricamente homogênia. Com isso, é esperado que as regras de classificação, em especial as que utilizam parâmetros espectrais, possam ser estendidas para todo o mosaico.

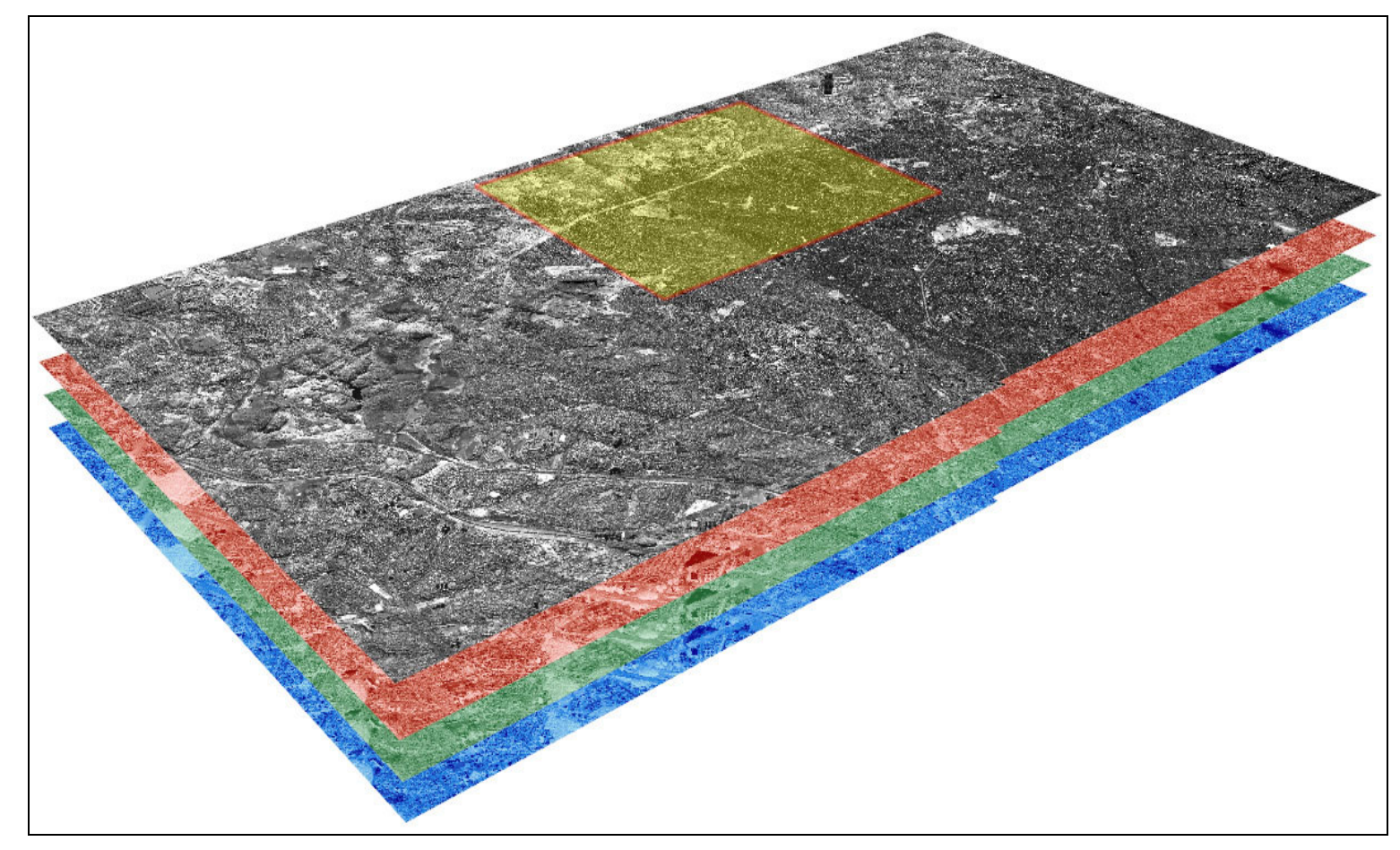

Figura 21 - llustração do mosaico das duas imagens multiespectrais geradas, recobrindo a área selecionada para o estudo, representada pelo retângulo preenchido em amarelo.

Vale ressaltar que, 0 tanto o empilhamento das bandas como a mosaicagem das imagens, foram procedimentos adotados para reverter a individualização das bandas espectrais e o corte das imagens em folhas articuladas. Essas características correspondem às especificações de entrega dos produtos do projeto contratado pelo Instituto Geológico da Secretaria do Meio Ambiente do Estado de São Paulo, proprietário das imagens IKONOS II adotadas neste trabalho. 


\subsubsection{Transformação entre sistemas de coordenadas}

Para que o mosaico gerado pudesse ser utilizado em conjunto com as informações disponíveis do Projeto Cabuçu de Baixo, foi necessário compatibilizar o conjunto de informações. O sistema referencial adotado foi o Córrego Alegre que, mesmo não sendo uma referência indicada para trabalhos contemporâneos e futuros, é o sistema de referência do qual os dados do Projeto Cabuçu de Baixo encontram-se disponíveis.

As imagens IKONOS II originalmente utilizadas, bem como o mosaico aqui produzido, possuem como referencial o sistema WGS-84, e as coordenadas projetadas em UTM (Universal Transversa de Mercator), zona 23 Sul (meridiano central $45^{\circ}$ Oeste). Assim como as etapas anteriores, a transformação entre os dois sistemas de coordenadas foi também realizada no programa Erdas Imagine, utilizando a ferramenta IMAGE REPROJECT. O mosaico passou a ter como sistema referencial o Córrego Alegre e projeção UTM, referente a zona 23 Sul.

\subsection{CRIAÇÃO DOS OBJETOS POR SEGMENTAÇÃO}

As técnicas de segmentação permitem a obtenção de grupos de pixels (segmentos) espacialmente próximos e que possuam características espectrais e radiométricas parecidas. É um processo comumente utilizado na classificação de imagens, no intuito de classificar, posteriormente, os segmentos em categorias. Para a classificação de imagens orientada a objeto, a introdução do conhecimento somente pode ser efetivada após a segmentação da imagem e a geração dos objetos relacionados (ANTUNES, 2003).

O processo de segmentação foi desenvolvido no programa eCognition. Utilizaram-se nessa segmentação as quatro bandas da imagem IKONOS II, aplicando-se o mesmo fator de peso à todas. Diferentes parâmetros de escala, responsável pelo controle da dimensão máxima dos segmentos, forma e grau de 
compactação, responsáveis pelo ajuste dos segmentos à natureza geométrica das feições presentes na imagem, foram intensivamente testados, até que fosse atingida uma configuração em que os segmentos pudessem ser eleitos como representantes de ruas e demais feições urbanas de interesse na metodologia, como descrito em Freauman e Wolf (2005).

A segmentação sobre composições coloridas foi fortemente dificultada pela alta variabilidade da resposta espectral das ruas e telhados, fruto da baixa homogeneidade entre essas feições. Isso fez com que as estratégias utilizadas para a deteç̧ão de ruas dependessem também das características geométricas das feições. Priorizou-se então o critério de forma e suavização desses objetos, conforme proposto por Pinho (2005) e Pinho et al. (2005). O melhor resultado obtido na segmentação ocorreu na combinação do fator 30 para a escala, 0,9 para a forma e 0,1 para a compacidade, ilustrados na Figura 21. Na seqüência, a Figura 23 ilustra o resultado da segmentação.

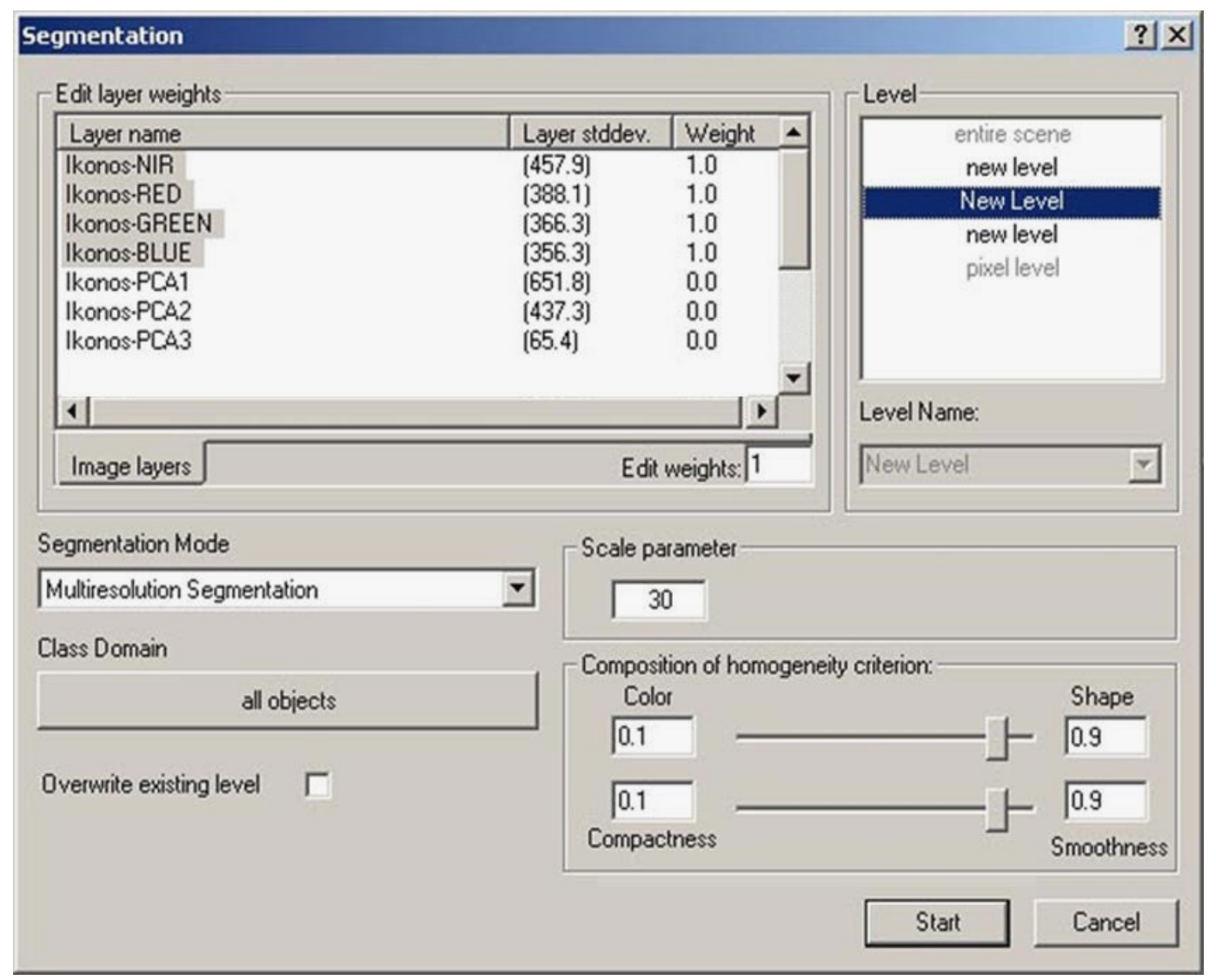

Figura 22 - Tela capturada do programa eCognition contendo os parâmetros e os dados utilizados na segmentação. 


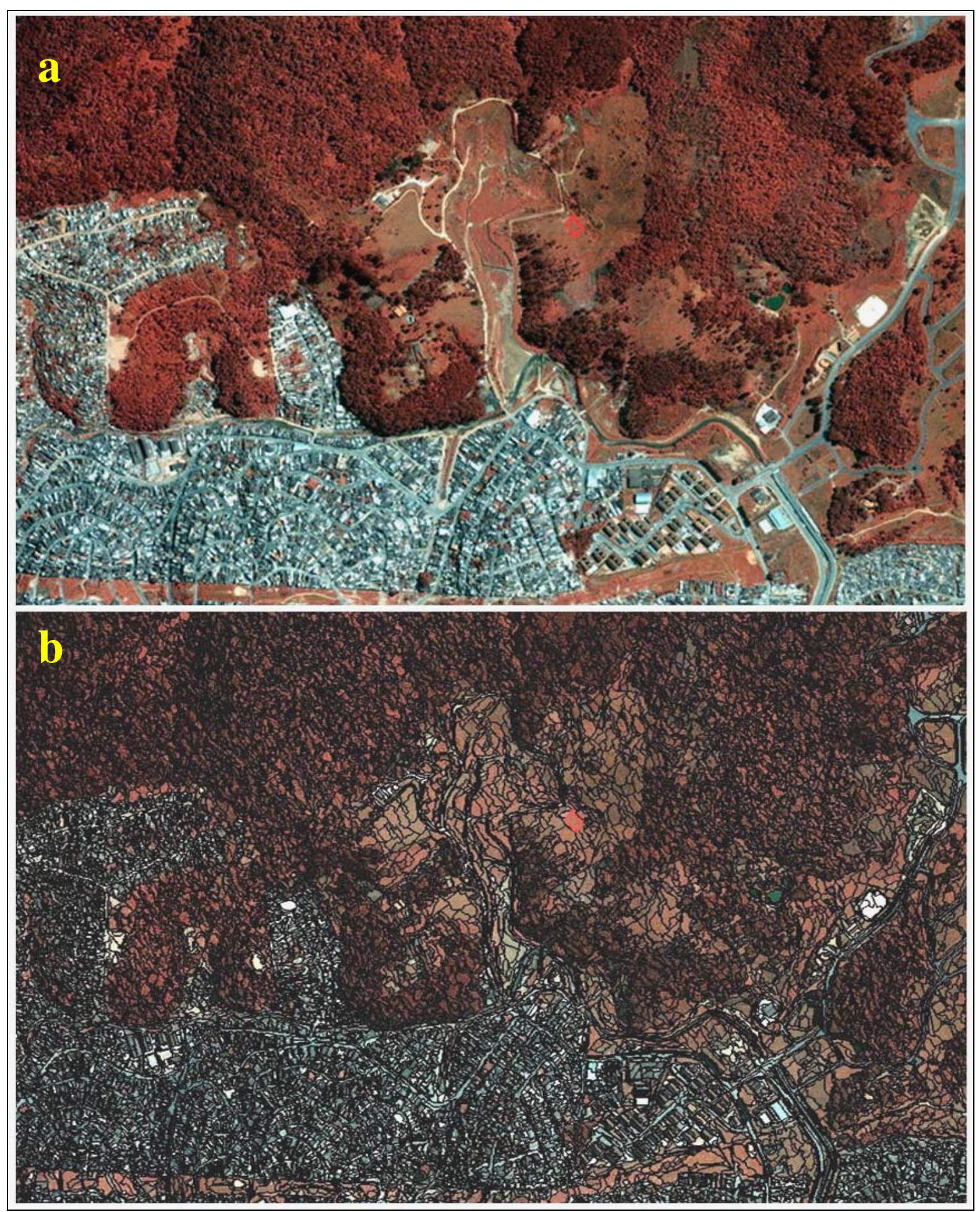

Figura 23 - Imagem parcial da área de estudo (a) e a respectivo resultado da segmentação (b). Os menores elementos gerados refletem a largura das vias mais periféricas. 
Embora o eCognition permita o desenvolvimento da classificação em diferentes níveis de segmentação (multiresolution classification), somente um nível foi empregado nesta aplicação. Optou-se pela utilização de um nível único de segmentação por se considerar o resultado, então obtido, suficiente para as análises propostas. O uso da segmentação multiresolução tem propiciado a melhor separação hierárquica das classes, através do relacionamento entre sub-objetos e super-objetos. A metodologia aqui utilizada não aborda a hierarquia entre objetos de diferentes níveis de segmentação, mas sim o relacionamento contextual dos objetos para com o contexto em que os mesmos estão presentes no cenário urbano. $\mathrm{Na}$ ausência do aplicativo, essa decisão de trabalhar com apenas um nível pode facilitar a implementação de rotinas que similares, uma vez que a segmentação multiresolução é um produto patenteado da Definiens Imaging $\mathrm{GmbH}$.

\subsection{COMPONENTES PRINCIPAIS}

A alta correlação entre as bandas espectrais originais nas imagens multispectrais de sensoriamento remoto, decorrente da redundância de informações presentes nas mesmas, usualmente demanda maior esforço computacional e resultados ineficientes nos processos de classificação. O uso da técnica de componentes principais tem o objetivo de atenuar os efeitos dessa correlação, transformando as combinações lineares existentes nas bandas originais em novas bandas (chamadas de componentes principais) que são combinações linearmente independentes a partir das bandas originais, e que retêm a maior parte da informação contida nas bandas originais em um número menor de componentes.

A análise de componentes principais é uma técnica matemática que permite a redução, ou remoção, de redundâncias entre bandas espectrais através da rotação e translação dos eixos no espaço de atributos espectrais. Por meio de uma transformação matemática, gera-se um novo conjunto de dados, não 
correlacionados, e que apresentam, decrescentemente, a máxima porcentagem de variabilidade das informações contidas nas bandas originais. Esse procedimento garante a separabilidade espectral dos objetos presentes na cena e é uma outra maneira de se prospectar informação sobre objetos urbanos em imagens de sensoriamento remoto. Uma abordagem mais profunda sobre redução de dimensionalidade dos dados pode ser vista em Kohn (1998) e Duda and Hart (1973), e sua aplicação em sensoriamento remoto pode ser vista em Tso and Mather (2001), Pinilla (1995), Schowengerdt (1983) e Moik (1980).

As três primeiras componentes principais juntas são responsáveis por quase $100 \%$ do total de informações presentes na imagem multispectral, porém minimizando a redundância de informações entre as mesmas, como ocorre nas bandas originais.

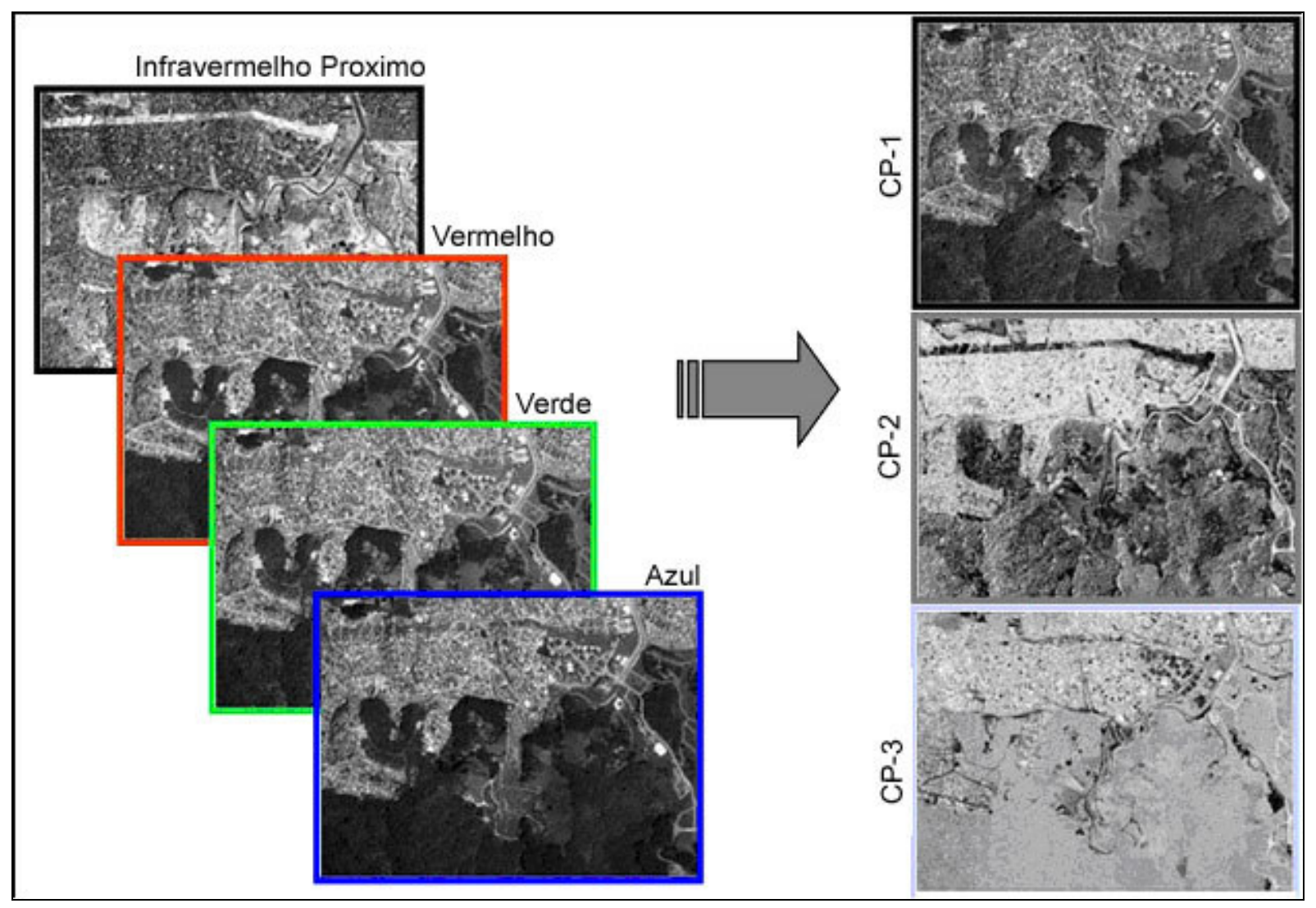

Figura 24 - Ilustração das 4 bandas espectrais das imagens IKONOS II utilizadas, e as respectivas componentes principais computadas e utilizadas no desenvolvimento do trabalho. 
Seguindo a metodologia utilizada em Nobrega et al (2006), computaramse as três primeiras componentes principais (CP-1, CP-2 e CP-3) à partir das quatro bandas da imagem IKONOS II (Figura 24). Esse processamento foi desenvolvido no programa Erdas Imagine utilizando a ferramenta PRINCIPAL COMPONENTS ANALYSIS. Por serem as bandas originais compostas por imagens de 11 bits, 0 aplicativo efetua a leitura das mesmas e as trabalha em 16 bits. Essa gama maior na radiometria é utilizada para evitar a perda de informação presente na imagem original. Na prática, os arquivos gerados de 16 bits demandam mais memória de armazenamento e conseqüentemente um maior tempo de processamento. Todavia, uma atenção especial deve ser dada ao considerar os valores absolutos do nível de cinza dos pixels das imagens aqui obtidas. As componentes principais geradas com 16 bits serão posteriormente combinadas às bandas originais de 11 bits através da customização de funções no aplicativo eCognition, descrito no item 4.5 deste capítulo.

Nesse trabalho, o uso combinado dessas componentes e das demais bandas espectrais da imagem permitiu a melhor discriminação tanto das áreas com solo exposto quanto das superfícies impermeabilizadas, que deram suporte a detecção das vias não pavimentadas e pavimentadas, respectivamente.

\subsection{DEFINIÇÃO DAS CLASSES DE INFORMAÇÃO}

A metodologia de detecção das vias na periferia urbana aqui proposta envolveu a identificação de um conjunto maior de feições de cobertura de solo, além das vias propriamente ditas. A classificação das imagens multispectrais de alta resolução espacial utilizadas recorreu, não somente a informações de caráter espectral, mas também a informações geométricas e contextuais das feições contidas nas mesmas. Para que se atingisse os objetos representantes do sistema viário, alguns passos foram necessários no sentido de possibilitar a filtragem das classes indesejadas, e com isso prover uma gama maior de informações para apoiar as regras de classificação. 
Devido à característica de ocupação recente e não planejada da expansão urbana na área de estudo, as vias apresentam diferentes estruturas geométricas como larguras e extensões variáveis, alta variabilidade quanto a direção, devido a topografia acidentada em grande parte do terreno, diferenças quanto a pavimentação (asfalto, concreto, asfalto coberto por terra, terra úmida e terra seca), além dos constantes obstáculos presentes nas vias, como veículos estacionados, objetos pintados ou deixados sobre a via, feira-livre, sombra, etc.

Propôs-se neste trabalho, uma forma de contornar, passo a passo, as dificuldades apresentadas, criando para isso categorias extra de informação, aqui denominadas de classes indesejadas. Ademais, a classificação das vias não pavimentadas e das vias pavimentadas depende de características espectrais e contextuais nas quais elas estão inseridas. Dessa forma, optou-se pela identificação de áreas correspondentes a solo exposto e áreas correspondentes a cobertura impermeabilizada do solo, dando suporte a classificação dos padrões de via.

Foi então proposta a classe ÁREA IMPERMEABILIZADA e algumas classes dela derivada como CONCRETO e VIA PAVIMENTADA. Também as classes VEGETAÇÃO, SOMBRA E TELHADO CERÂMICO, para atingir com sucesso a classe SOLO EXPOSTO, conforme proposto em Nóbrega et al (2006). Baseado nessa classe e na classe CAMINHO, a classe VIA NÃO PAVIMENTADA foi definida. A Figura 25 esquematiza a composição das classes utilizadas.

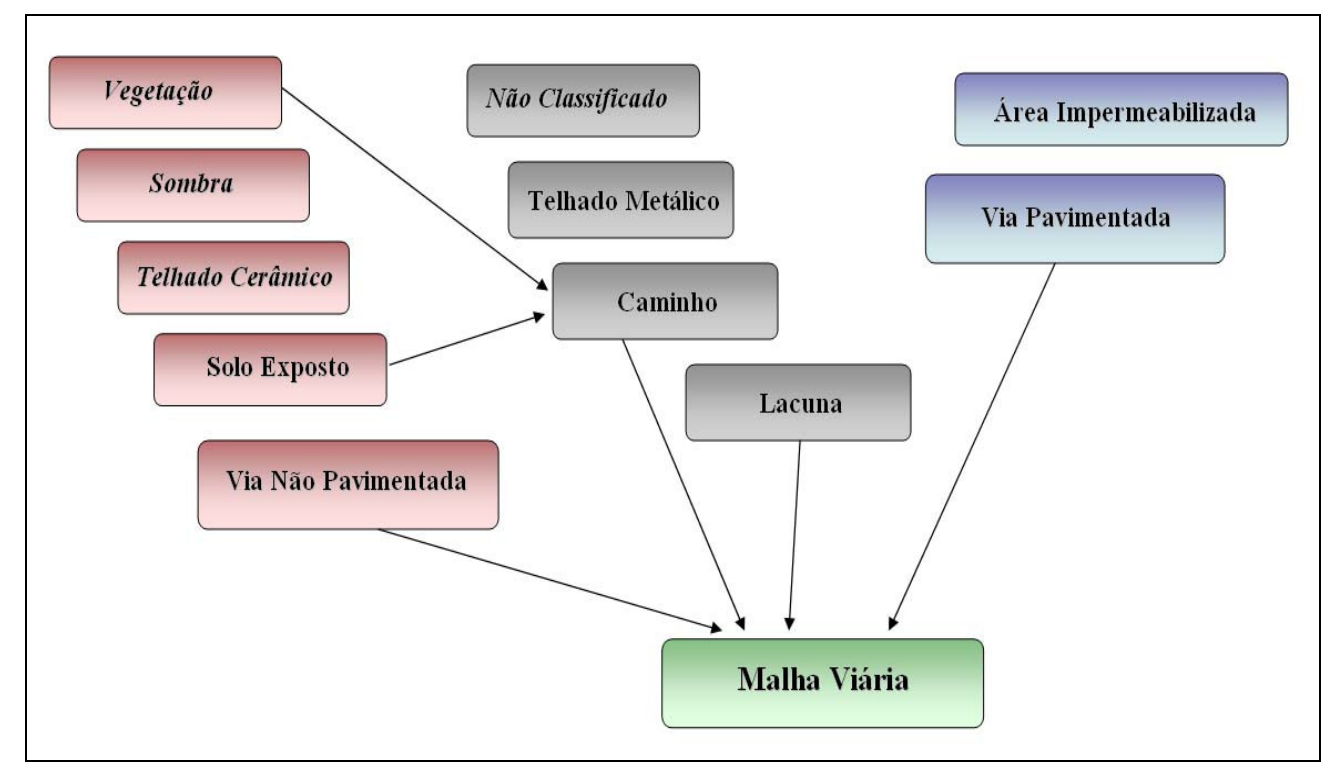

Figura 25 - Classes auxiliares e classes principais utilizadas na metodologia do presente trabalho. 


\subsection{DETECÇÃO DE ÁREAS DE SOLO EXPOSTO}

A existência de vias não pavimentadas, ou vias com excessiva presença de terra sobre o pavimento, ocorre em abundância na região de estudo. Desconsiderar tais fatores poderia acarretar resultados errôneos. Nesse sentido, a combinação de um novo nível de informação (solo exposto) apoiando a classificação forneceu maior precisão e segurança para o processo.

Para detecção dessas áreas, três classes de objetos foram definidas em seqüência: VEGETAÇÃO, SOMBRA E SOLO EXPOSTO, descritas em detalhe em Nóbrega et al. (2006). O método tem como base o emprego de planos de informação para vegetação, sombra e solo exposto, aplicados nesta mesma seqüência, sendo os dois primeiros necessários devido a complexidade da cena. A identificação e o tratamento, em separado, da sombra e da vegetação, aumentaram a capacidade de detectar solo exposto. Vale ressaltar que na literatura acima mencionada, as áreas de solo exposto foram obtidas com exatidão de $81,3 \%$.

\subsection{1 Áreas vegetadas}

A identificação das áreas vegetadas recorreu ao uso do índice de vegetação por diferença normalizada - NDVI, mencionado anteriormente no item 2.3.2. No entanto, NDVI aqui apresentado computa a diferença normalizada dos valores médios de cinza entre as bandas do infravermelho próximo e vermelho para os objetos, conforme eq.(14). Quanto maior a presença de vegetação, maior o valor de cinza na imagem NDVI resultante. A equação do NDVI foi então introduzida no programa eCognition e aplicada à todos os segmentos (objetos) detectados na imagem. Por ser um índice normalizado, o valor calculado do NDVI varia de -1 a 1. 


$$
N D V I=\left(\frac{\mu \text { Infravermelho } \_ \text {proximo }-\mu \text { Vermelho }}{\mu \text { Infravermelho _ proximo }+\mu \text { Vermelho }}\right)
$$

onde: $\mu N I R=$ nível de cinza médio dos objetos na banda correspondente ao infravermelho próximo;

$\mu R e d=$ nível de cinza médio dos objetos na banda correspondente ao vermelho.

Foram consideradas como áreas de vegetação, os objetos que apresentaram NDVI superiores a 0,18, limiar esse obtido via amostragens realizadas na imagem, especificamente sobre os objetos seguramente visualizados como sendo vegetação. A facilidade com que o NDVI fornece informações sobre a área com cobertura vegetal, foi o principal motivador. A Figura 26 ilustra as áreas classificadas como vegetação.

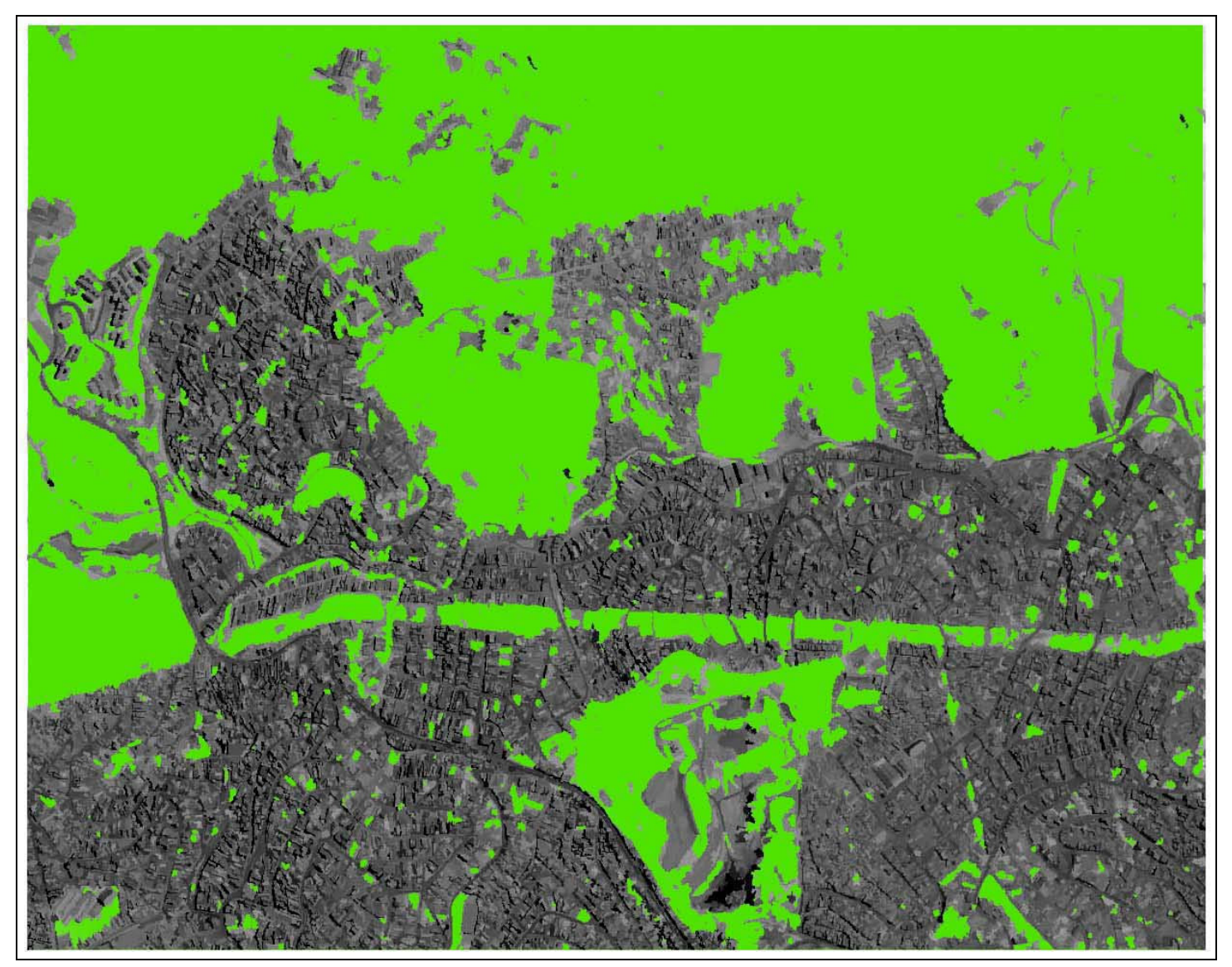

Figura 26 - Resultado da classificação das áreas vegetadas (em verde). 
O objetivo da introdução do NDVI no contexto desse trabalho foi o de detectar, em primeira instância, as áreas cobertas por vegetação que, conseqüentemente, não correspondem ao sistema viário, objeto principal do trabalho. Uma vez detectadas as áreas vegetadas, essas foram posteriormente mascaradas para que não atrapalhassem a detecção das áreas de solo exposto. Esse mascaramento não corresponde à remoção dessas áreas em si, mas sim a inclusão de regras condicionais no fluxo do processo classificatório. Em outras palavras, as regras de classificação atribuídas para as categorias remanescentes (SOMBRA, SOLO EXPOSTO, VIAS PAVIMENTADAS, VIAS NÃO-PAVIMENTADAS, etc.) incluíram como premissa a condição de que a classe VEGETAÇÃO não fora atribuída ao objeto.

\subsection{2 Áreas de sombra}

De forma análoga a detecção das áreas vegetadas, a detecção de áreas cobertas com sombra foi estabelecida como etapa preliminar para a então identificação das áreas de solo exposto. Nessa etapa, foi criada uma categoria incluindo sombras e outras áreas extremamente escuras, existentes na imagem.

Identificar as áreas de sombra, à primeira vista, aparenta ser algo simples. Considerando que o sensor do satélite IKONOS II é passivo, ou seja, não é uma fonte emissora de radiação eletromagnética, mas sim foi calibrado para receber a irradiância refletida dos raios solares nos objetos presentes na superfície terrestre. Se por um lado a idéia básica é analisar as respostas espectrais dos objetos sombra, que devem ser baixas, quase nulas, em todas as bandas, por outro há o fato de que muitas das feições presentes na imagem apresentam baixos valores espectrais. o que acaba causando confusão no processo classificatório. Nobrega et al (2006) apresentaram uma proposta de identificação das áreas de solo exposto utilizando classificação baseada em objetos de imagens multispectrais de alta 
resolução espacial, como subsídio aos estudos de erosão laminar do solo urbano. Para tanto, foi proposto um índice auxiliar de sombra, baseado na diferença entre os valores de cinza dos objetos na banda azul e na primeira componente principal, como forma de prover melhor poder de discriminação para as áreas efetivamente compostas de sombra.

Analisadas de forma independente, as duas bandas apresentam pequenas diferenças em níveis de cinza entre os objetos sombra em relação aos demais. No entanto, combinando-as, como sugere a eq.(15), obtém-se uma imagem resultante com maior contraste entre os objetos de sombra e os demais.

$$
\text { Indicador de sombra }=\mu \text { Blue }-\mu P C 1
$$

onde: $\mu B l u e=$ nível de cinza médio por objeto na banda correspondente ao azul; $\mu P C 1$ = nível de cinza médio por objeto na primeira componente principal.

A identificação das áreas de sombra foi então baseada na análise do índice auxiliar indicador de sombra. A função de pertinência utilizada apresenta como limites os valores -450 e -400 . Esses limiares foram estabelecidos após análises realizadas em amostras manualmente retiradas dentre os objetos fotointerpretados como áreas de sombra.

Para a composição da regra, qualquer objeto que não tenha sido classificado como vegetação e que apresente índice indicador de sombra inferior a 450 passa a ser classificado como sombra, com 100\% de certeza. Objetos (não vegetação) que apresentarem índices indicadores de sombra superiores a -400 não recebem o rótulo SOMBRA. No entanto, objetos com índice entre -450 e -400 passam a ser classificados como sombra com um certo grau de incerteza, modelado pela função de pertinência representada no gráfico da Figura 27. Na seqüência, a Figura 28 ilustra o resultado da classificação das áreas de sombra. 


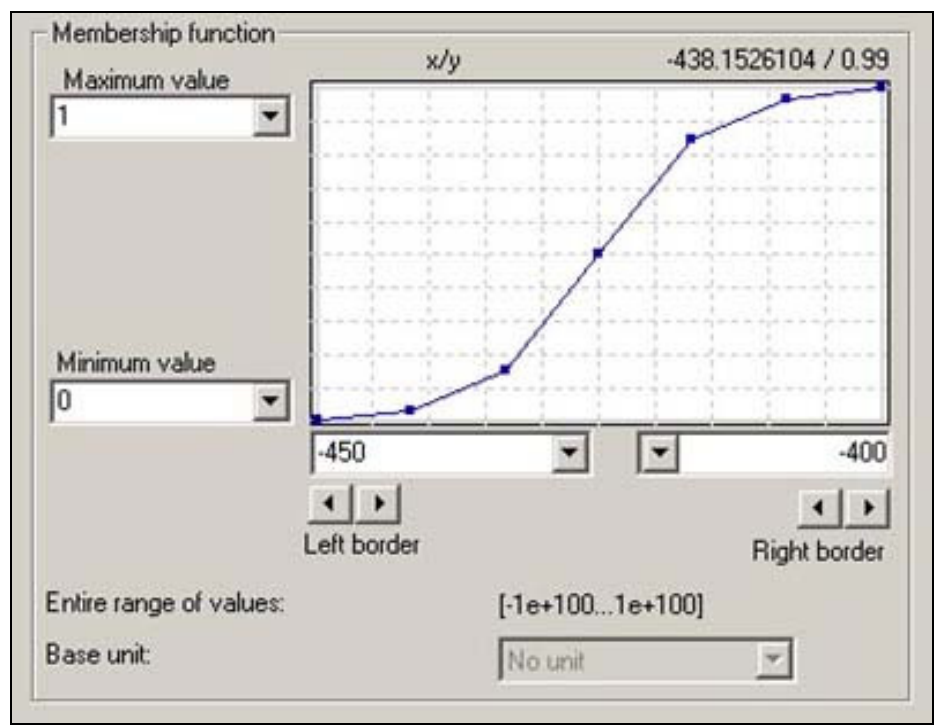

Figura 27 - Gráfico da função de pertinência modelada para o índice indicador de sombra.

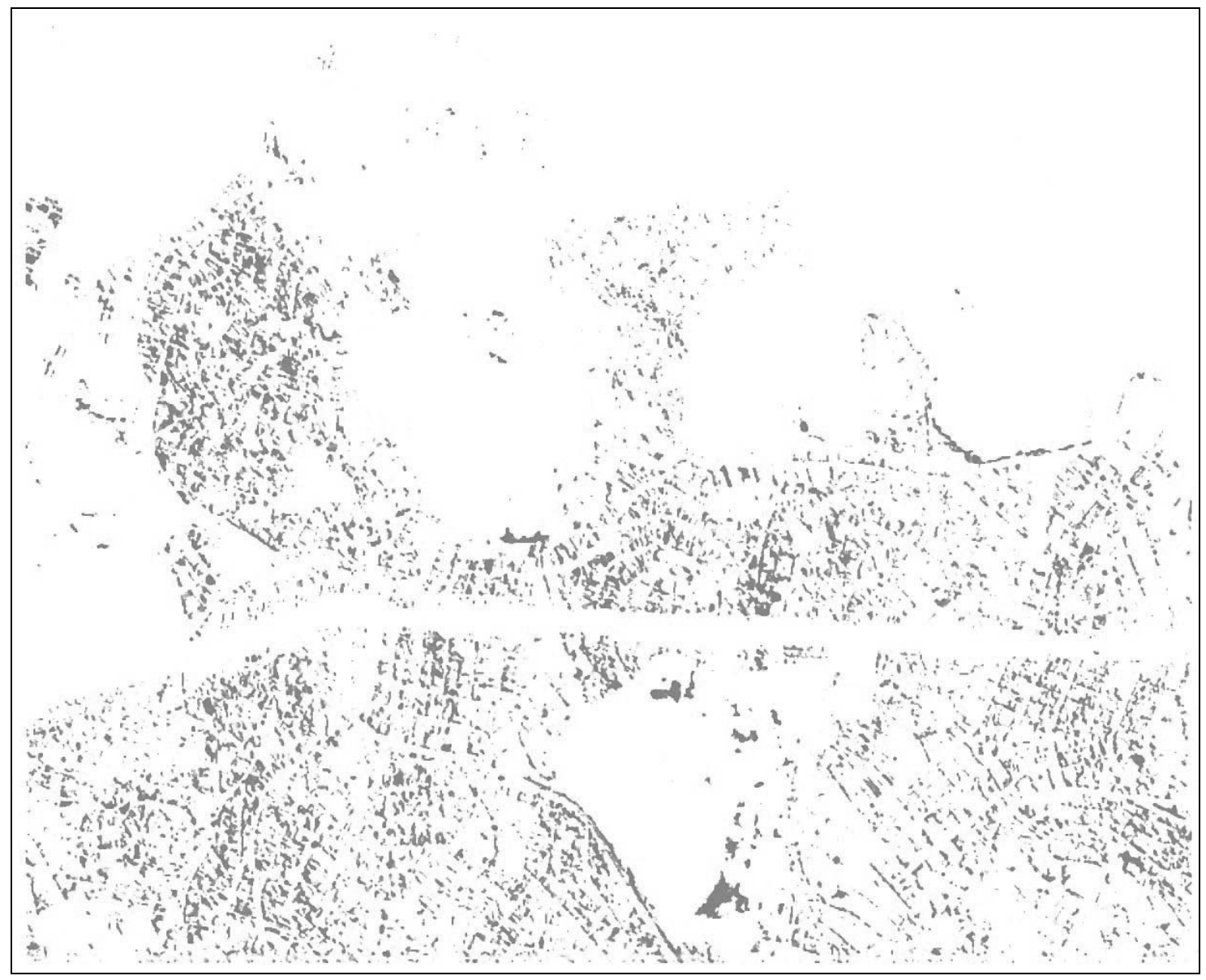

Figura 28 - Resultado da classificação das áreas de sombra. 
Vale ressaltar que os procedimentos tomam por base operações sobre imagens de 11 bits. Os valores negativos modelados na equação advêm da subtração entre as médias espectrais dos objetos na primeira componente principal em relação à banda azul. As áreas de sombra apresentaram baixos valores em ambas as bandas, porém a subtração proposta forneceu um maior contraste entre as áreas efetivamente consideradas sombra e as demais áreas, o que minimizou a ocorrência de erros na classificação.

Assim como as áreas vegetadas, as áreas de sombra foram detectadas a fim de fornecer maior poder de discriminação para a identificação das áreas de solo exposto.

\subsubsection{Solo exposto}

Uma vez identificadas as áreas de vegetação e de sombra, partiu-se para a detecção das áreas de solo exposto, utilizando o mesmo princípio de análise condicional, ou seja, somente foram levados em conta nessa etapa do processo os objetos que não se adequaram nas classes VEGETAÇÃO e SOMBRA.

Para a identificação dos objetos pertencentes a classe SOLO EXPOSTO, utilizou-se o índice indicador de solo proposto em Nóbrega et al (2006), o qual combina a terceira componente principal e a banda azul, produzindo uma eficiente referência para o processo classificatório.

Apesar da terceira componente principal, por si só, permitir a identificação das áreas de solo exposto devido ao baixo valor resultante se comparado aos demais objetos presentes na imagem, a excessiva heterogeneidade da área de estudo dificultou a discriminação dessas áreas. Em outras palavras, ocorreu com muita freqüência a excessiva confusão entre objetos de solo exposto, edificações e ruas sujas (no sentido próprio da palavra). 
A inclusão da banda azul permitiu uma melhora significativa na separabilidade desses objetos, devido a baixa refletância e a menor variância dos solos nus nessa banda, quando comparada às demais bandas espectrais. A eq.(16) mostra como o índice indicador de solo exposto foi desenvolvido. A constante negativa introduzida no denominador apenas reduz, e inverte, o valor final do índice, tornando-o compatível ao limitado número de casas decimais disponível no programa eCognition.

$$
\text { Indicador de solo exposto }=\left(\mu P C 3^{*} \mu B / u e\right) /(-100.000)
$$

onde: $\quad \mu P C 3=$ nível de cinza médio na terceira componente principal.

Assim como na definição das funções de pertinência anteriores, a definição dos limiares utilizados para a classe SOLO EXPOSTO foi baseada em amostragens manualmente estabelecidas sobre os objetos identificados visualmente como sendo área de solo exposto. A função de pertinência da classe SOLO EXPOSTO, cujo gráfico esta representado na Figura 29, tem como limite inferior o valor 0,8 e limite superior o valor 1,5 .

Objetos com valores inferiores a 0,8 não foram considerados áreas de solo exposto, objetos com valores superiores a 1,5 foram classificados como SOLO EXPOSTO com 100\% de certeza. Objetos que apresentaram valores do índice entre os limites acima apresentados foram atribuídos à classe SOLO EXPOSTO com o correspondente percentual de incerteza definido pelo gráfico da função de pertinência. 


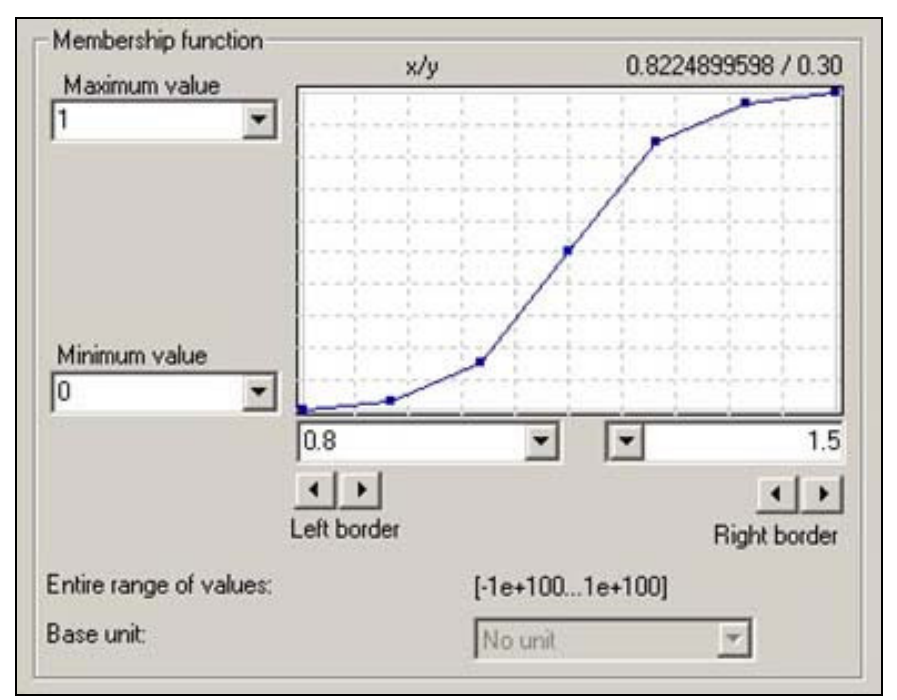

Figura 29 - Gráfico da função de pertinência modelada para a classe SOLO EXPOSTO.

No entanto, ocorreu que ao considerar somente a propriedade espectral dos objetos, a classificação das áreas de solo exposto acarretou excessiva confusão, devido a identificação errônea de algumas feições como as coberturas cerâmicas (ou telhados cerâmicos) presente em parte das edificações. Um exemplo claro disse pode ser visto na Figura 30, onde o simples resultado do indicador de solo exposto não foi suficiente para discriminar áreas efetivas de solo exposto e telhados cerâmicos. Com base na imagem resultante da ação do índice indicador de solo exposto, abaixo ilustrada, as áreas mais claras representam os objetos com maiores valores dos índices e as áreas mais escuras as demais feições. 


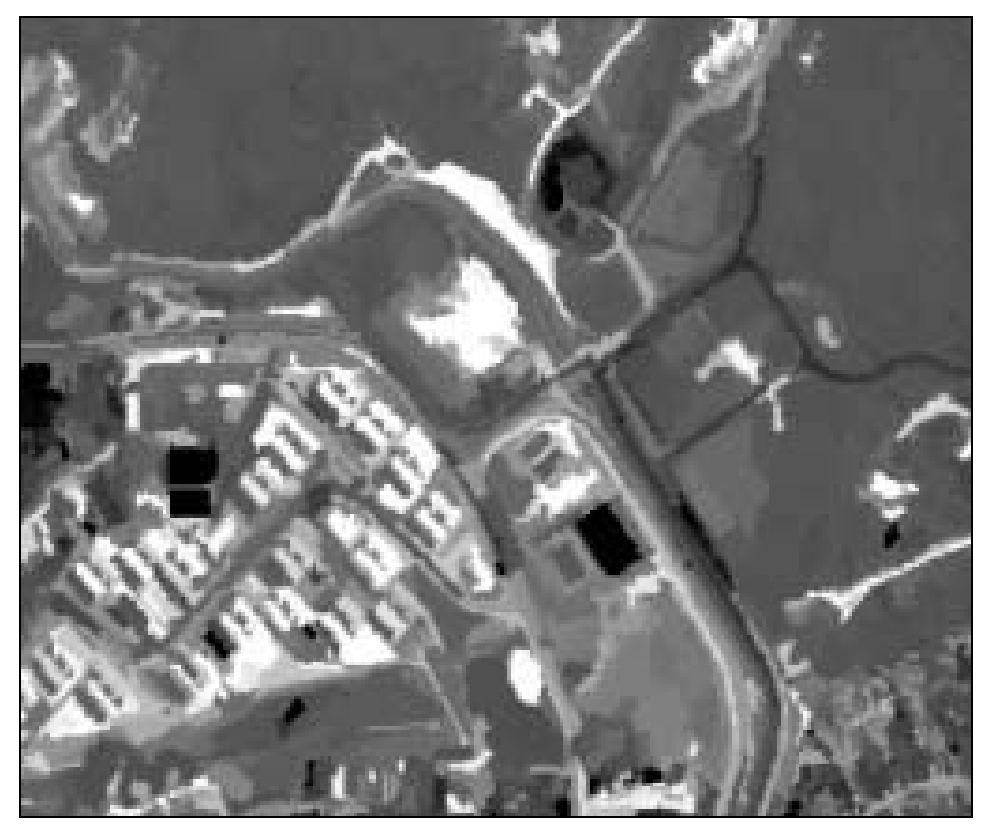

Figura 30 - Resultado da ação do índice indicador de solo exposto. Áreas claras representam as respectivas áreas de solo exposto e telhados cerâmicos.

Todavia, a mesma área, quando observada em uma composição colorida, permite visualizar claramente o erro causado pela superestimação das áreas de solo exposto. Nem todos as feições claras ilustradas na figura acima são, na realidade, áreas de solo exposto, como as coberturas cerâmicas dos conjuntos residenciais. A Figura 31 mostra um exemplo dos respectivos telhados cerâmicos classificados erroneamente como sendo solo exposto. 


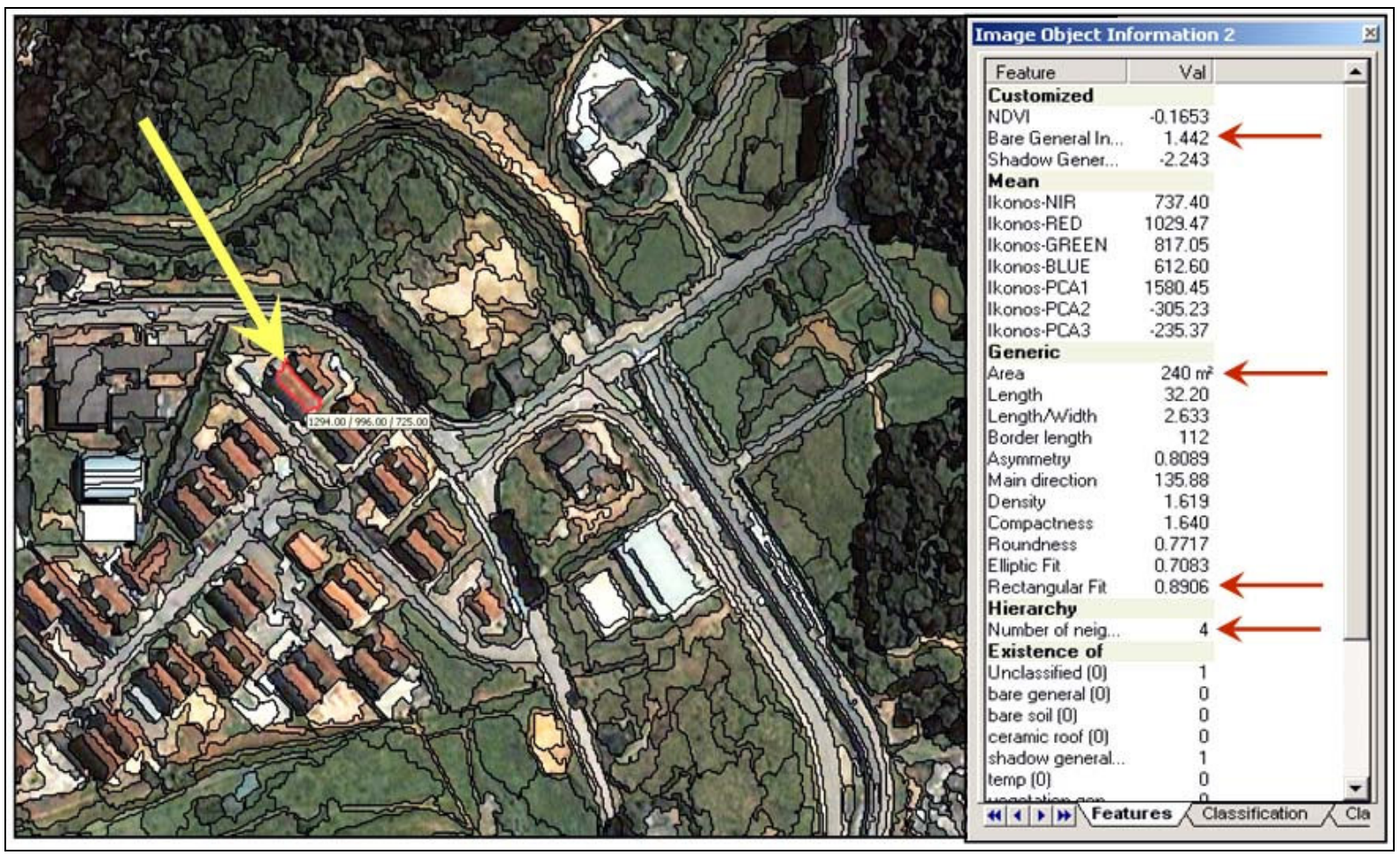

Figura 31 - Telhados cerâmicos detectados erroneamente como áreas de solo exposto, passíveis de serem detectados, ao se considerarem as características geométricas e topológicas nas estratégias de classificação.

A introdução de regras baseadas nas propriedades geométrica e topológica dos elementos permitiu a melhor separação entre elementos efetivamente considerados como solo exposto e como telhados cerâmicos. Da geometria dos objetos, foram analisados a área e o ajuste retangular. Objetos previamente classificados como SOLO EXPOSTO foram então submetidos à um processo de filtragem para a possível identificação dos mesmos como sendo telhados cerâmicos.

Assim como a análise da área e do coeficiente de ajuste retangular, a existência de objetos da classe SOMBRA como vizinho de objetos da classe SOLO EXPOSTO foi a condicional topológica imposta nas regras. Em Nobrega et al (2006), esse procedimento de filtragem proporcionou uma significativa redução do erro de comissão, e elevou a precisão final na identificação das áreas de solo exposto.

Para o desenvolvimento das três regras condicionais, faz-se necessário um breve entendimento sobre os parâmetros e coeficientes utilizados: 
- Área é definida pela quantidade de pixels cobertos pelo objeto, multiplicada pela resolução dos pixels contada no terreno. Nesse trabalho a área de cada objeto passa a ser a própria quantidade de pixels desses objetos.

- O ajuste retangular é um dos índices métricos existentes no eCognition e pode ser entendido como um coeficiente entre o objeto em si e um retângulo de área idêntica a do objeto, ajustado sobre o mesmo. Um objeto perfeitamente retangular terá 0 ajuste perfeito entre o próprio objeto e o retângulo então criado. Objetos de formas diferentes apresentarão lacunas e excessos, como ilustra a Figura 32. O valor máximo desse índice é 1 e ocorre em casos onde o objeto representa perfeitamente um retângulo.

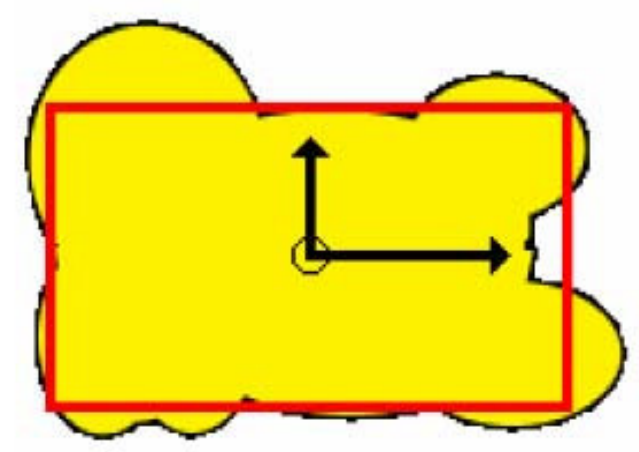

Figura 32 - Ilustração do índice de ajuste retangular do eCognition.

De forma similar às regras definidas anteriormente, foram executadas amostragens em objetos reconhecidos como edificações com cobertura cerâmica. Foi então observado o comportamento desses objetos quanto à variação da área, do coeficiente de ajuste retangular e da presença de sombra como objeto imediatamente vizinho. Com base nessas observações, foram definidos os limiares das respectivas funções de pertinência.

A Figura 33 ilustra o gráfico da função de pertinência empregada para definir a área utilizada na filtragem. Objetos da classe SOLO EXPOSTO com área superior a $100 \mathrm{~m}^{2}$ são aceitos pelo filtro. Objetos dessa mesma classe com valor de área menor que $100 \mathrm{~m}^{2}$ podem ser aceitos pelo filtro, com um determinado grau de incerteza. 


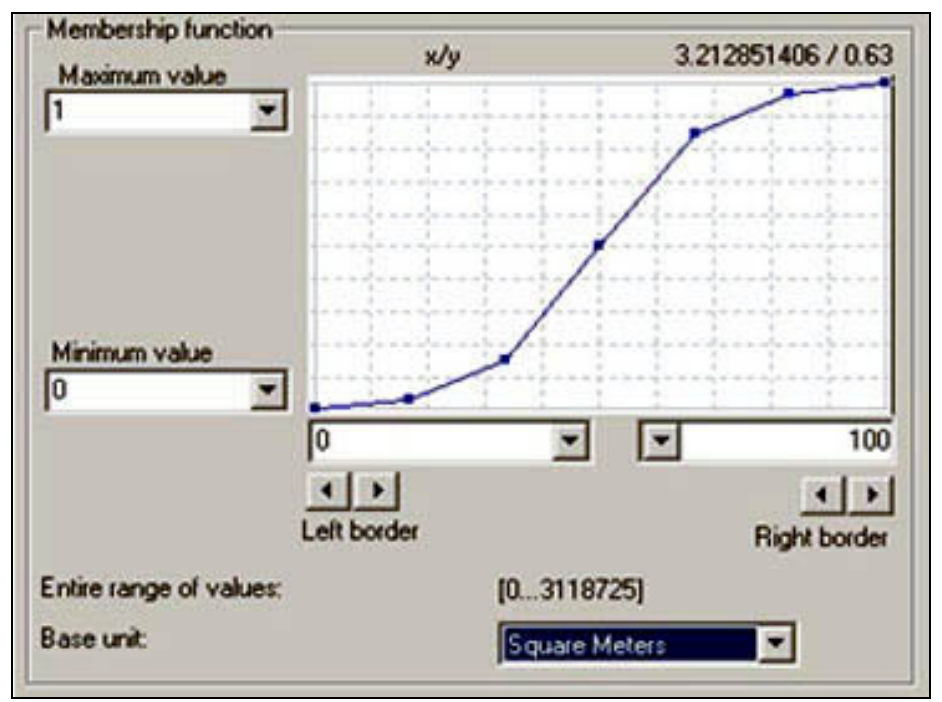

Figura 33 - Função de pertinência modelada para área para a filtragem dos objetos TELHADO CERÂMICO pré-classificados como SOLO EXPOSTO

A função de pertinência modelada na Figura 34 considera que grande parte das edificações que possuem telhados cerâmicos tem a forma retangular. Com isso, as condições impostas pelo filtro não são contempladas para os objetos da classe SOLO EXPOSTO que tenham coeficientes de ajuste retangular inferiores a 0,6 . Valores entre 0,6 e 1 são aceitos e atribuídos graus de incerteza. $O$ valor 1 corresponde a um objeto perfeitamente retangular, aceito sem restrição pelo filtro.

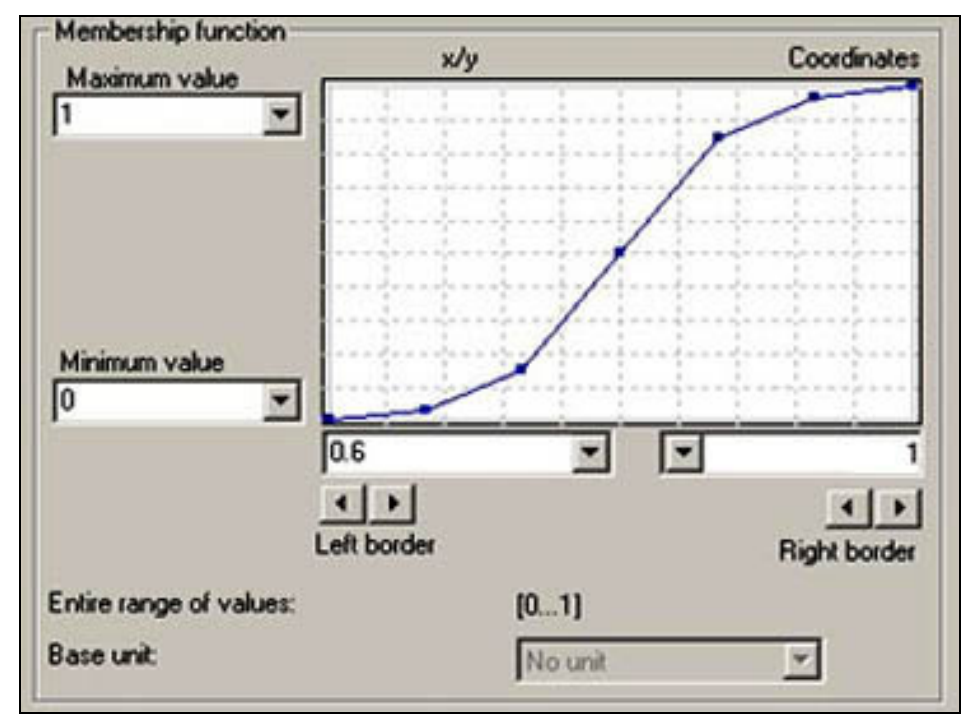

Figura 34 - Função de pertinência modelada para o coeficiente de ajuste retangular para a filtragem dos objetos TELHADO CERÂMICO pré-classificados como SOLO EXPOSTO. 
A terceira condição imposta para a detecção e remoção dos telhados cerâmicos dos objetos classificados como solo exposto foi a vizinhança com sombra. Não exatamente a presença ou não de sombra foi considerada, mas sim um percentual de contato com objetos classificados como sombra. Esse percentual é dado pela razão entre a faixa de contato e o perímetro do objeto. Um elemento totalmente cercado por sombra terá seu índice igual a 1 (ou 100\%), o que na prática não ocorre. Foram encontradas, via amostragem nos objetos presentes na imagem, faixas de contato entre telhados e suas respectivas sombras projetadas no solo, cujos índices variavam entre 0,1 e 0,5. Esses limiares foram inseridos na função de pertinência, conforme ilustra a Figura 35.

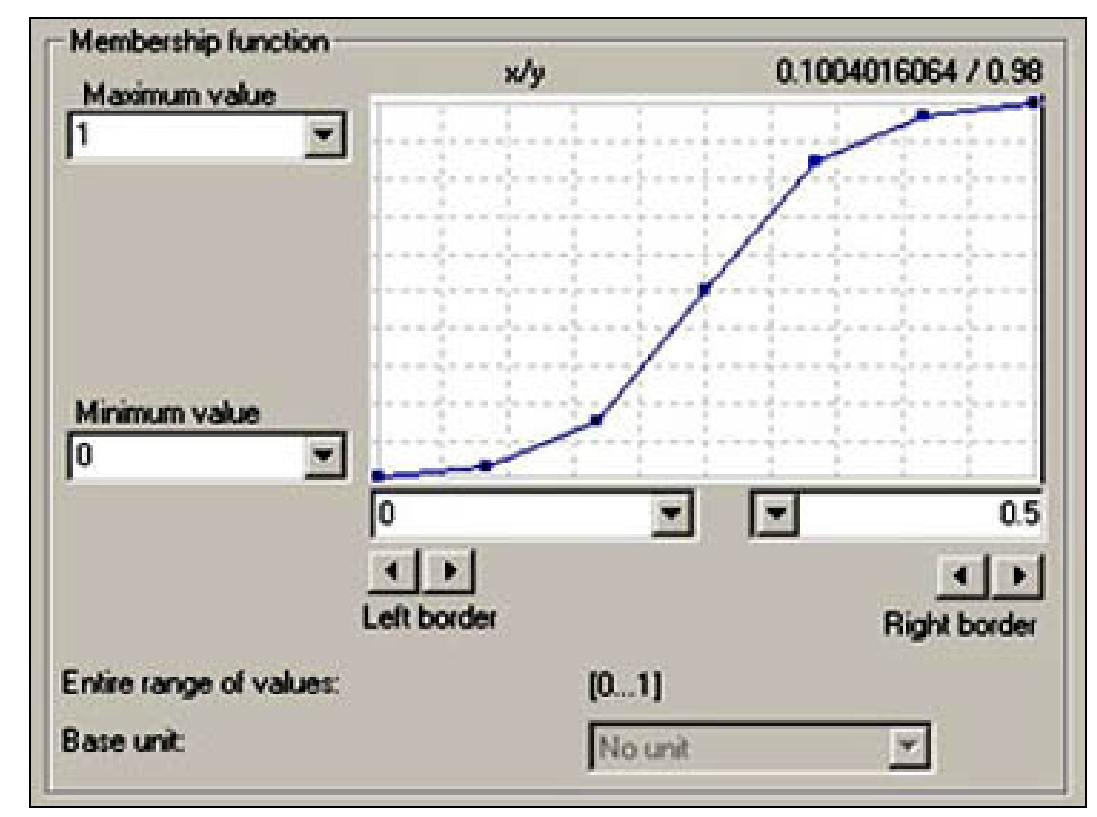

Figura 35 - Função de pertinência modelada para objetos da classe SOLO EXPOSTO vizinhos de objetos da classe SOMBRA, visando filtragem dos mesmos para reclassificação como sendo TELHADO CERÂMICO.

Como resultado da filtragem dos telhados cerâmicos houve a redução das áreas de solo exposto, em especial de objetos isolados, sem conexão ou vizinhança com outros objetos de solo exposto. A Figura 36 ilustra o resultado da classificação das áreas de solo exposto, que foi utilizada como base para a classificação das vias não pavimentadas. 


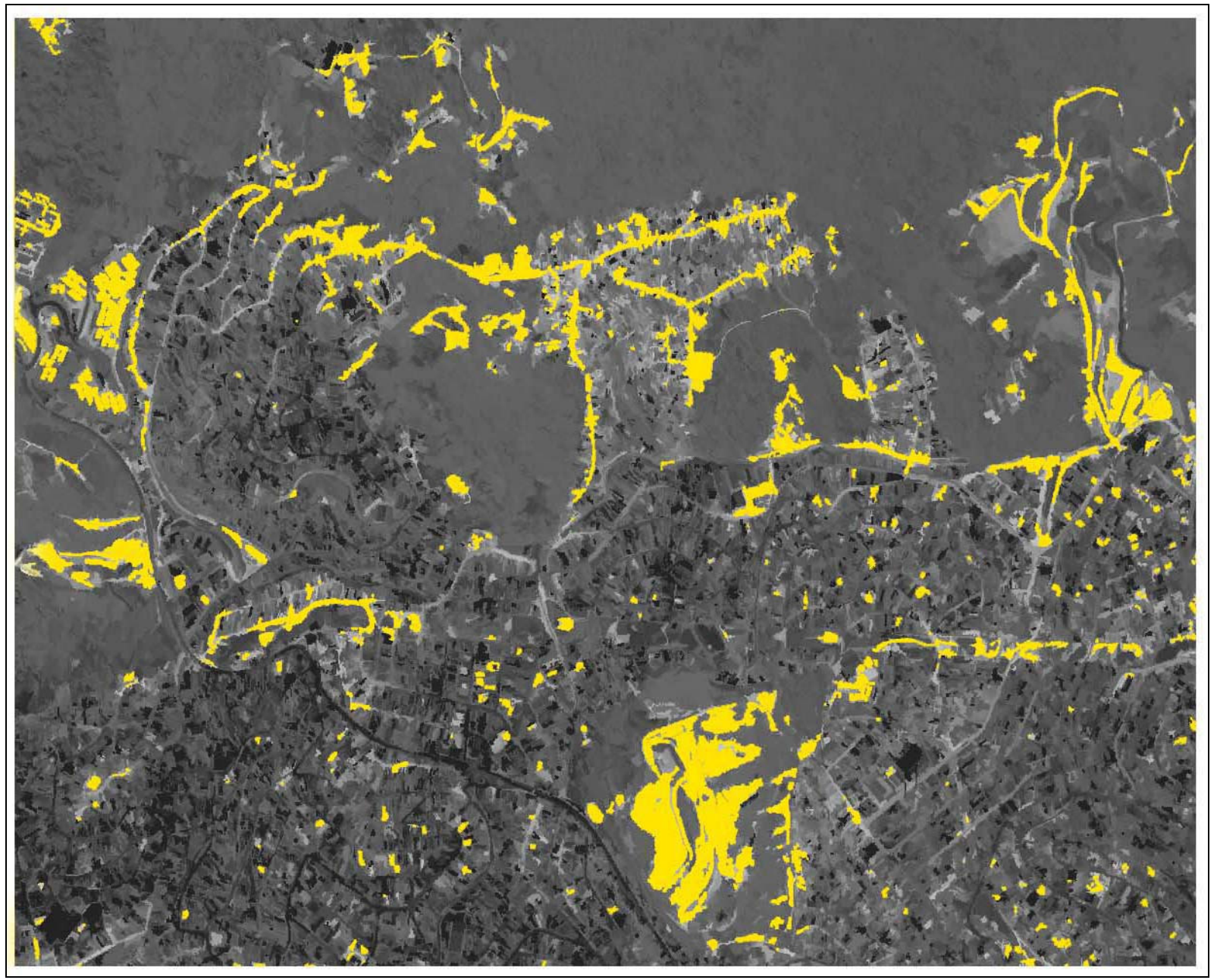

Figura 36 - Resultado da classificação das áreas de solo exposto (em amarelo), base para a detecção das vias não pavimentadas.

\subsection{DETECÇÃO DE ÁREAS IMPERMEABILIZADAS}

A detecção de áreas com cobertura de solo impermeabilizada foi inserida nesse trabalho com o objetivo de auxiliar a discriminação entre ruas pavimentadas e ruas não pavimentadas. Para isso foram utilizados a segunda componente principal e os objetos provenientes da segmentação, descrito em Nóbrega, O'Hara e Quintanilha (2006).

A segunda componente principal resulta de uma combinação linear ponderada das variáveis originais não correlacionadas com a primeira componente 
principal. Ela representa a máxima proporção da variabilidade restante não explicada pela primeira componente. Trabalhos recentes como Vijayaraj, O'Hara e Younan (2005) e Cablk e Minor (2003) mencionam o uso da segunda componente principal como indicativo da mancha urbana ou área urbanizada.

Contudo, o simples emprego da segunda componente principal não é suficiente para produzir um mapeamento da área urbanizada, nem tampouco das áreas impermeabilizadas. Não é prudente estabelecer uma regra global de emprego de componentes principais pela própria natureza desses dados. O padrão de informação presente nas componentes principais estará sempre atrelado às características da área imageada, como por exemplo à variância dos dados, dada pela heterogeneidade da cobertura do solo.

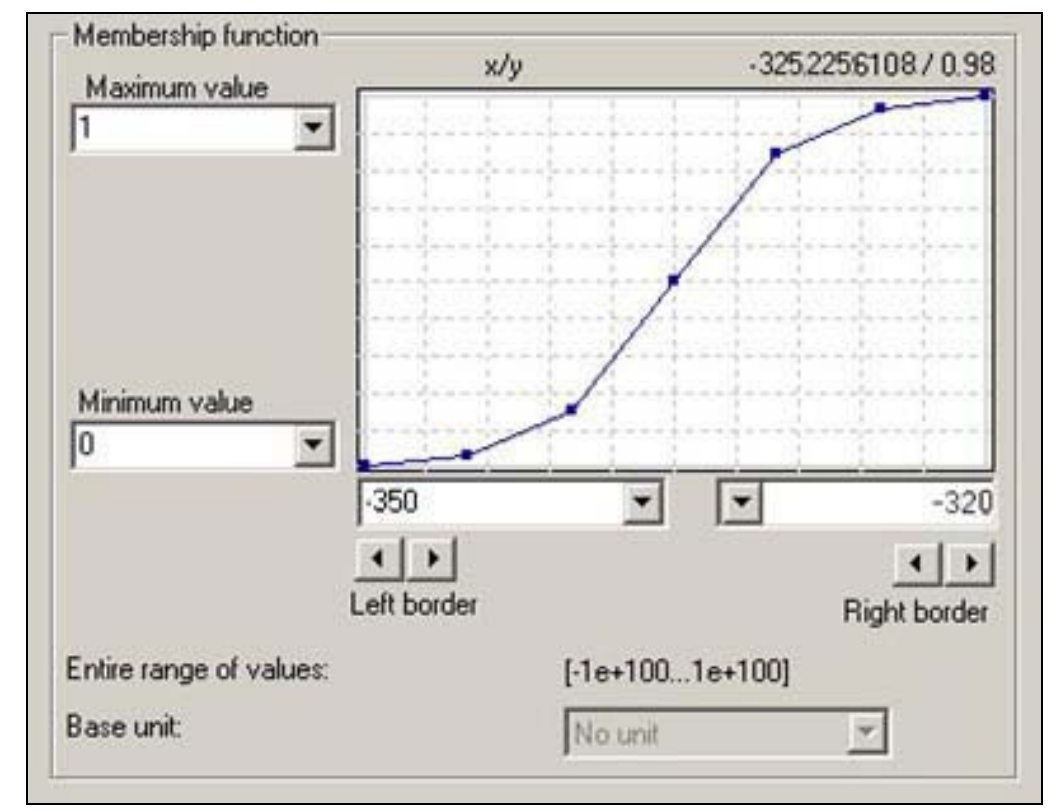

Figura 37 - Gráfico da função de pertinência atribuída a classe ÁREA IMPERMEABILIZADA.

$\mathrm{Na}$ prática, a definição dos limiares a serem atribuídos à função de pertinência da classe ÁREA IMPERMEABILIZADA foi baseada em amostragens do valor médio dos objetos, seguramente visualizados e interpretados como sendo cobertura impermeabilizada do solo, em relação a segunda componente principal. Objetos como edificações, pavimentos de concreto e asfalto e demais elementos encontrados no cenário urbano foram selecionados e seus valores utilizados na 
composição da regra, cujo gráfico é ilustrado na Figura 37. Objetos com valores menores que -350 não se encaixaram no perfil da classe ÁREA IMPERMEABILIZADA. Objetos com valores entre -350 e -320 foram atribuídos a classe com determinados graus de incerteza. Valores superiores a -320 foram classificados como ÁREA IMPERMEABILIZADA com 100\% de certeza.

Nas imagens de alta resolução espacial aqui utilizadas, pode-se observar pela segunda componente que grande parte das feições urbanas apresentam altos valores de nível de cinza em relação a média dos. Em uma generalização, é possível afirmar que as áreas representadas por altos valores de nível de cinza na segunda componente principal (áreas claras, ilustrado a esquerda na Figura 38), correspondem, em sua maioria, à mancha urbana. Com um pouco mais de detalhe, nota-se que a maioria dessas feições caracterizam as áreas de cobertura impermeabilizada do solo, ilustradas em azul na Figura 38 a direita.

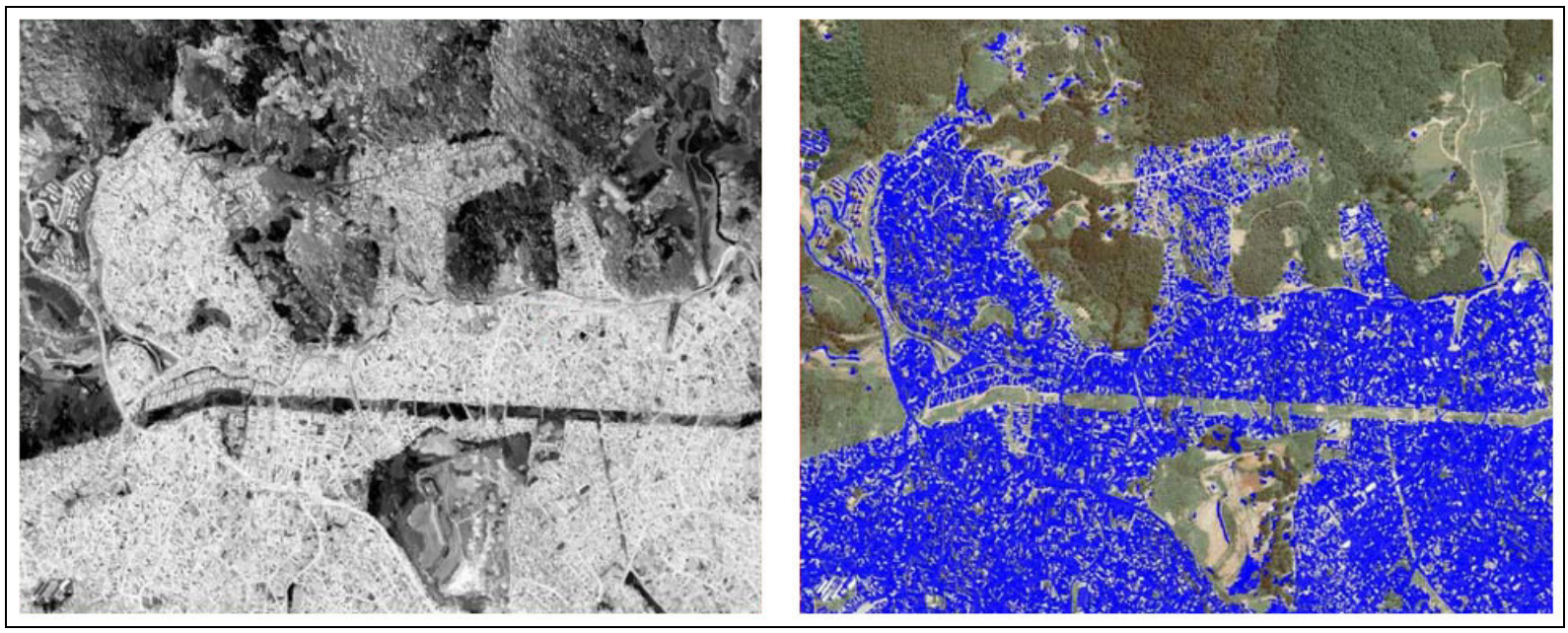

Figura 38 - Segunda componente principal (esquerda) utilizada na identificação de áreas com superfícies impermeabilizadas (direita, em azul). (NOBREGA et al, 2006).

Apesar de nem todas as feições urbanas observadas na área de estudo possuírem as características de altos valores em relação a segunda componente principal, foi observado que essa regra contemplou as vias pavimentadas, como asfalto e concreto. Sobretudo, a definição dessa regra de classificação considerou em primeira instância a não similaridade dos objetos para com as classes VEGETAÇÃO, SOMBRA E SOLO EXPOSTO. 


\subsection{DETECÇÃO DO SISTEMA VIÁRIO}

Como objetivo principal do presente trabalho, a detecção das vias foi desenvolvida explorando as propriedades geométricas. No entanto, percorrer todos os objetos gerados pela segmentação e verificar a aderência dos mesmos em relação a regras baseadas em parâmetros extraídos somente de sua geometria acabaria onerando o esforço computacional sem produzir os resultados esperados, uma vez que a maioria dos objetos, sabidamente, não corresponde a malha viária.

Como forma de minimizar o volume de cálculos e imposição de regras condicionais, os planos de informação SOLO EXPOSTO e ÁREA IMPERMEABILIZADA apoiaram o processo de classificação. A procura pelas propriedades geométricas foi reduzida significativamente ao considerarem apenas os objetos dessas duas classes, uma vez que toda a malha viária esta contida na união de ambas.

Para a identificação dos objetos representantes da malha viária nas duas classes acima mencionadas, a estratégia utilizada recorreu às regras baseadas na geometria dos objetos. O potencial das informações geométricas dos segmentos possibilitou eleger os objetos com características lineares, atribuindo para as regras os limiares obtidos em amostras manuais. Para a detecção desses elementos lineares a estratégia adotada concorda com a estratégia descrita por Skackelford e Davis (2003) e Ehlers et al (2006), as quais empregam uma função de parâmetros tais como assimetria, comprimento, largura, ajuste retangular e relações entre elas para detectar as vias. Tais conceitos são apresentados no item 2.9. A Figura 39 ilustra os planos de informação contextuais e geométricos utilizados na presente metodologia.

Procurou-se a máxima simplicidade para o desenvolvimento de regras eficazes logo nos primeiros ensaios, no entanto a extrema complexidade do cenário urbano, fruto da heterogeneidade das feições urbanas da área de estudo, obrigou, interativamente, a elaboração de etapas de filtragem de classes indesejadas. 


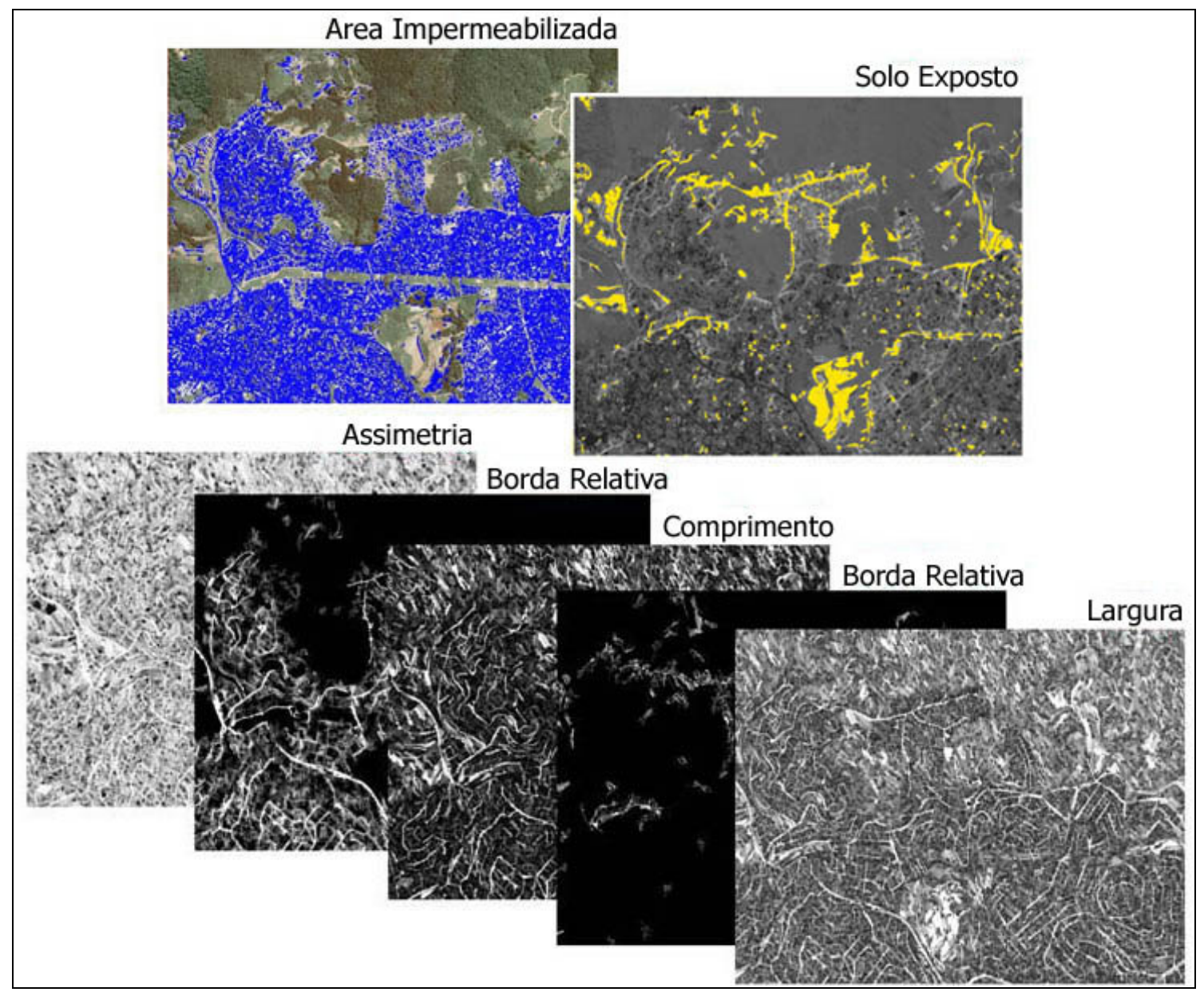

Figura 39 - Planos de informação usados na detecção e classificação das vias.

\subsubsection{Parâmetros utilizados}

Em fotointerpretação, ao serem consideradas as características geométricas das entidades escolhidas, especialmente em se tratando de áreas urbanas, deve-se ter em mente que as formas geométricas e o contexto no qual essas entidades se encontram são, em geral, conhecidos. Cabe ao usuário interpretar tais informações e as utilizar para enriquecer sua base de conhecimento. Nesse sentido, a metodologia proposta neste trabalho utilizou algumas estratégias para a classificação, apoiadas em classes auxiliares (empregando critérios de similaridade e não similaridade) e em regras específicas, que permitiram a detecção 
das vias utilizando como base as características geométricas das feições representadas na imagem.

Para que seja entendido como as características geométricas dos objetos são obtidas, o programa eCognition gera um banco de dados a partir da segmentação, o qual contém, a priori, as informações espectrais (média, máximo, mínimo, desvio padrão para cada banda espectral) e os parâmetros extraídos da forma dos objetos. As características geométricas são determinadas a partir de primitivas básicas, como área, perímetro, semi-eixos maior e menor, retângulo envolvente, elipse envolvente e esqueleto de cada objeto. Essas informações são armazenadas no banco de dados do aplicativo para simplificar as análises futuras. Há também a possibilidade de computar outros parâmetros, como coeficientes derivados do esqueleto, textura, relacionamento intra-objetos e interobjetos e funções implementadas. Uma vez computados, essas informações alimentam o banco de dados do aplicativo, de forma semelhante às informações primitivas.

Computacionalmente, as descrições geométricas dos objetos são obtidas de duas formas no eCognition: através da estatística de distribuição espacial dos pixels do objeto, que toma como base a matriz de covariância, ou através de um retângulo envolvente (bounding box) que, segundo Baatz et al (2004), é a forma mais simples, porém que pode não se adaptar às feições curvilíneas. Como solução, é sugerida a adoção de sub-objetos.

Os parâmetros geométricos básicos empregados nas regras de classificação desta pesquisa foram área, comprimento, largura, razão comprimento e largura, ajuste retangular, assimetria e borda relativa. A combinação dessas primitivas permite gerar novas informações, que podem ser utilizadas na classificação. Adicionalmente, parâmetros geométricos podem ser obtidos a partir da esqueletonização ou afinamento dos objetos, tornando-os de fato elementos lineares. Os conceitos de morfologia matemática, como os que se baseia 0 programa eCognition, podem ser vistos em Banon e Barreira (1994), e uma descrição do aplicativo e suas ferramentas pode ser encontrada em Baatz et al (2004). 


\subsubsection{Regras de classificação}

As regras de classificação foram definidas classe a classe, e a seqüência com que essas regras foram utilizadas definiu a estratégia da metodologia. A árvore de processos do eCognition permitiu configurar a estratégia de detecção da malha viária de forma seqüencial, como ilustra a Figura 40. Nessa seqüência, as chamadas para as funções de classificação consideraram os objetos já condicionados a uma determinada classe ou objetos ainda não classificados, considerando o propósito do dado momento. Em termos práticos, uma vez chamada a função de classificação, os objetos em questão passam a ser analisados segundo as condições impostas nas regras da classe específica em questão.

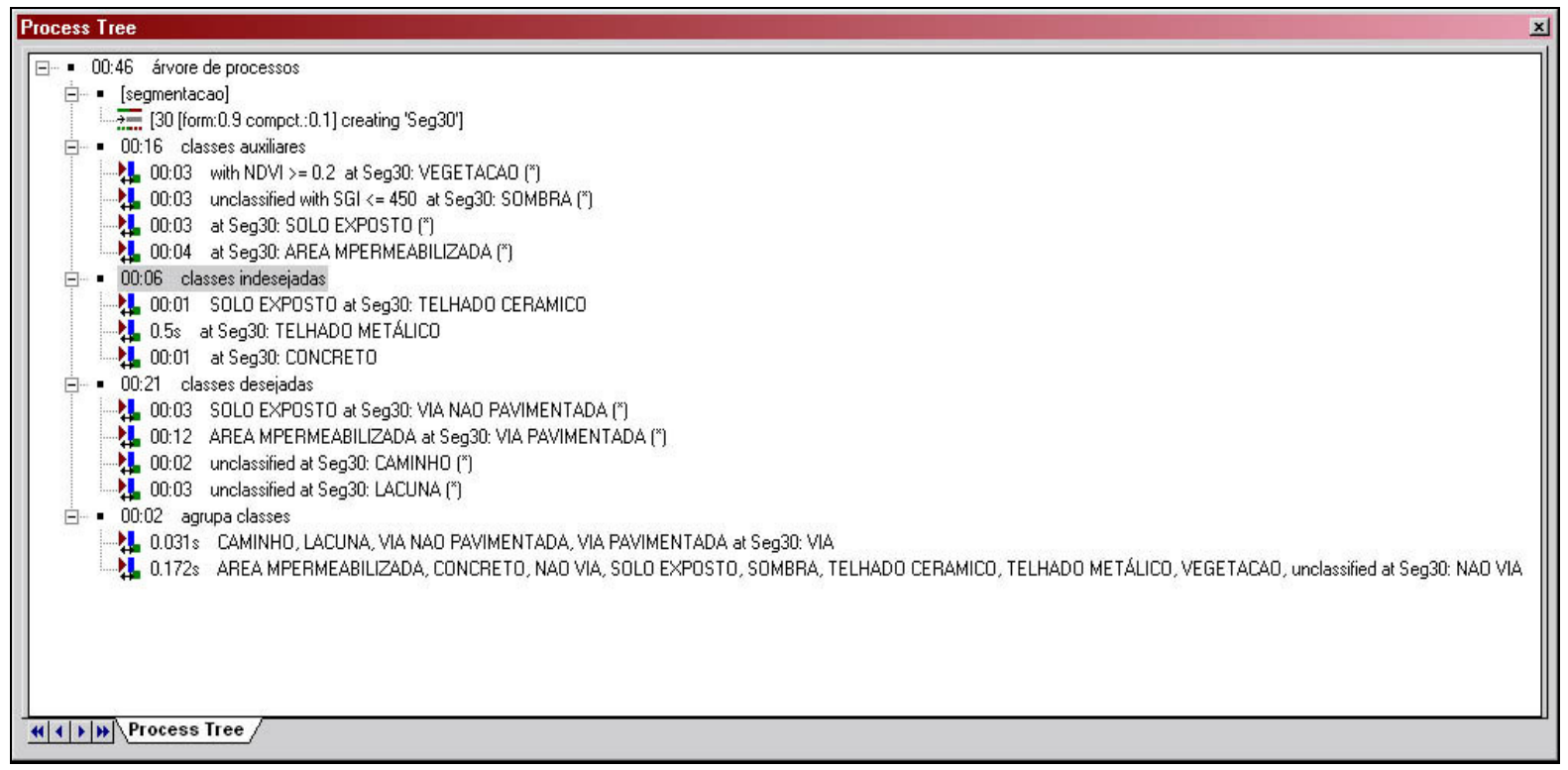

Figura 40 - Árvore de processos do eCognition indicando seqüência de passos da classificação.

A descrição das regras, nesse item, parte do entendimento consolidado sobre o processamento das classes auxiliares (SOLO EXPOSTO e ÁREA IMPERMEABILIZADA), descritas anteriormente. A seqüência seguinte relata a detecção dos objetos referentes às classes VIA PAVIMENTADA, VIA NÃO PAVIMENTADA, CAMINHO e LACUNA, mais especificamente, a imposição das regras baseadas em suas propriedades geométricas e contextuais. 
Para detecção das vias pavimentadas, a classe VIA PAVIMENTADA foi descrita em função dos seguintes fatores:

- Comprimento da borda: (descrito pela soma das bordas dos objetos que tocam o objeto em questão). A regra foi modelada por uma função monotônica ascendente com limites inferior e superior iguais a 140 e 150, respectivamente;

- Comprimento: função monotônica ascendente com limites inferior e superior iguais a 25 e 50 ;

- Razão: comprimento e largura: função monotônica ascendente com limites inferior e superior iguais a 2 e 3 ;

- Assimetria: função monotônica ascendente com limites inferior e superior iguais a 0,8 e 1 ;

- Similaridade para com a classe AREA IMPERMEABILIZADA

A classe VIA NÃO PAVIMENTADA foi descrita por:

- Razão: comprimento e largura: função monotônica ascendente com limites inferior e superior iguais a 2 e 3 ;

- Assimetria: função monotônica ascendente com limites inferior e superior iguais a 0,8 e 1 ;

- Similaridade para com a classe SOLO EXPOSTO

A classe CAMINHO, que representa parte das vias não pavimentadas que não foram contempladas pela regra anterior, foi descrita por:

- Área: função de densidade com limites inferior e superior iguais a 0 e 100;

- Coeficiente de ajuste retangular: função de densidade com limites inferior e superior iguais a 0,6 e 1;

- Assimetria: função de densidade com limites superior e inferior iguais a 0,7 e 1 ;

- Predominância da classe VEGETAÇÃO como vizinha. 
A classe LACUNA foi descrita por:

- Comprimento da borda: modelada pela função de densidade com limites inferior e superior iguais a 140 e 150;

- Razão comprimento e largura: função de densidade com limites inferior e superior iguais a 1 e 2 ;

- Predominância da classe AREA IMPERMEABILIZADA como vizinha;

- Assimetria: modelada pela função de densidade com limites inferior e superior iguais a 0,7 e 1 .

A Figura 41 apresenta as classes e as regras impostas a cada classe. A figura ilustra também o relacionamento entre as classes, que descreve a estratégia adotada na metodologia do presente trabalho. Os processos ilustrados em destaque têm seus resultados apresentados na Tabela 4.

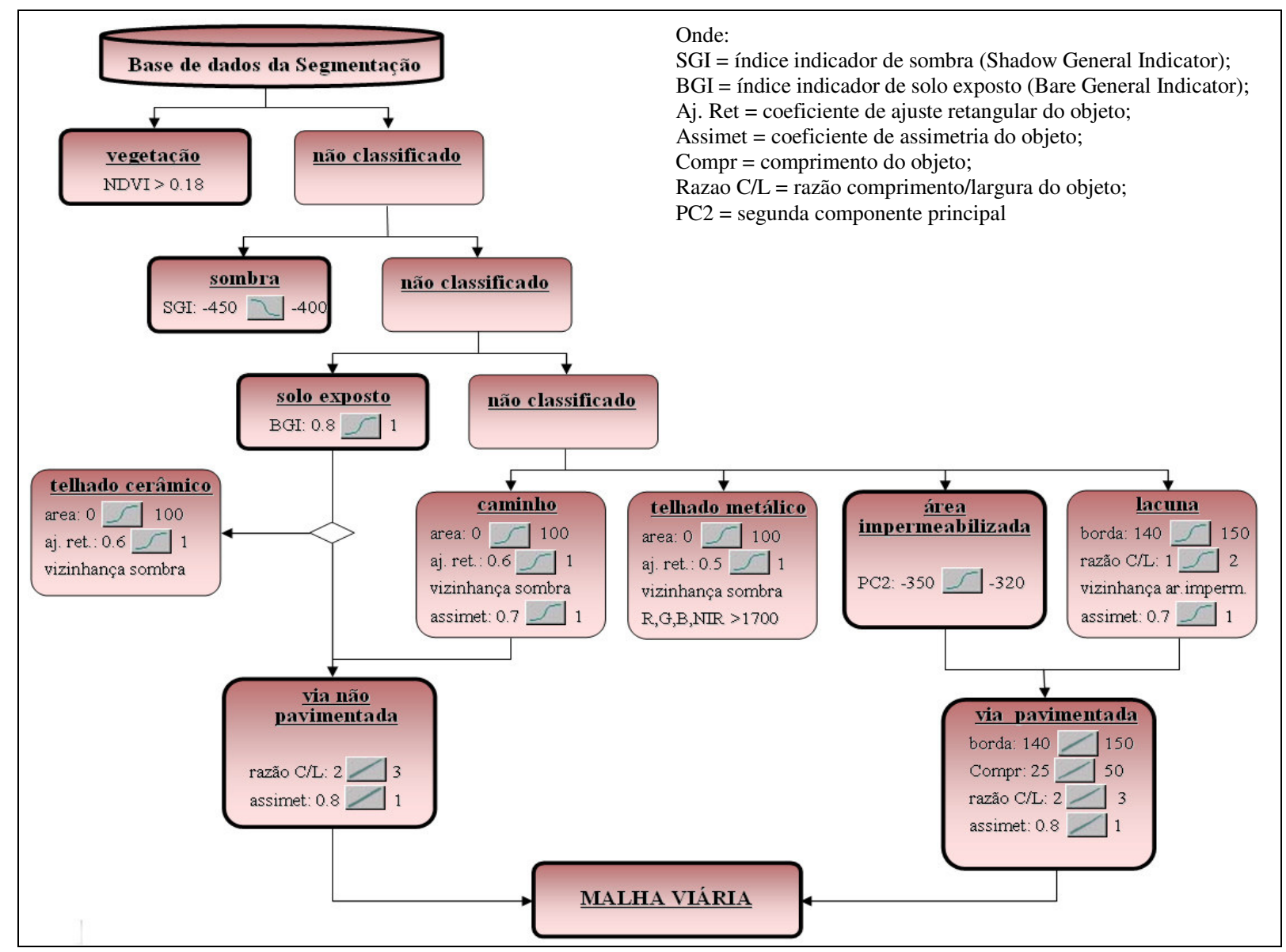

Figura 41 - Estratégia de detecção da malha viária definida pelas classes e respectivas regras de classificação impostas às mesmas. 
Tabela 4 - Seqüência dos passos mais relevantes e seus respectivos resultados, que descrevem as principais etapas na detecção da malha viária apresentada nesse trabalho.

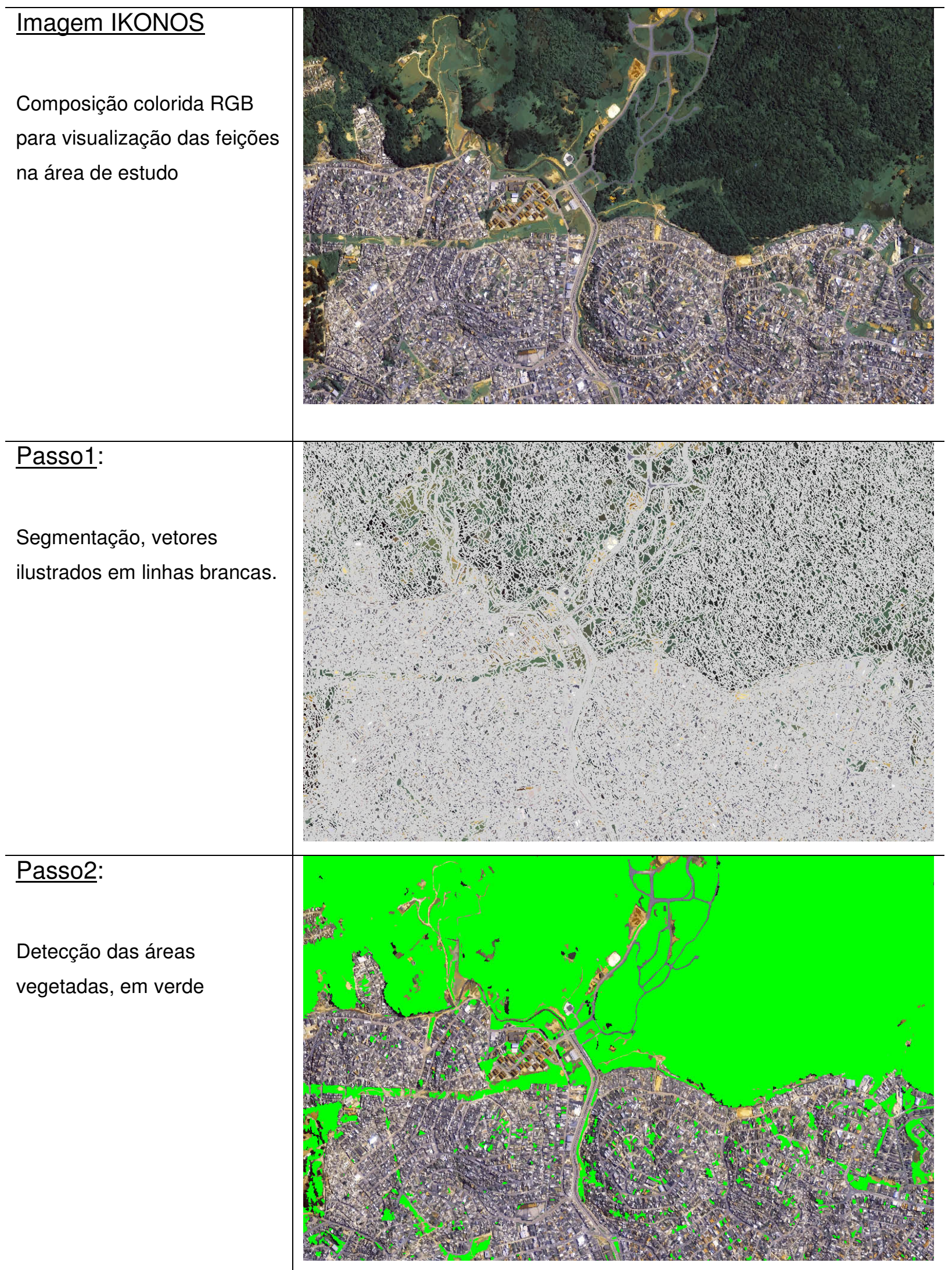




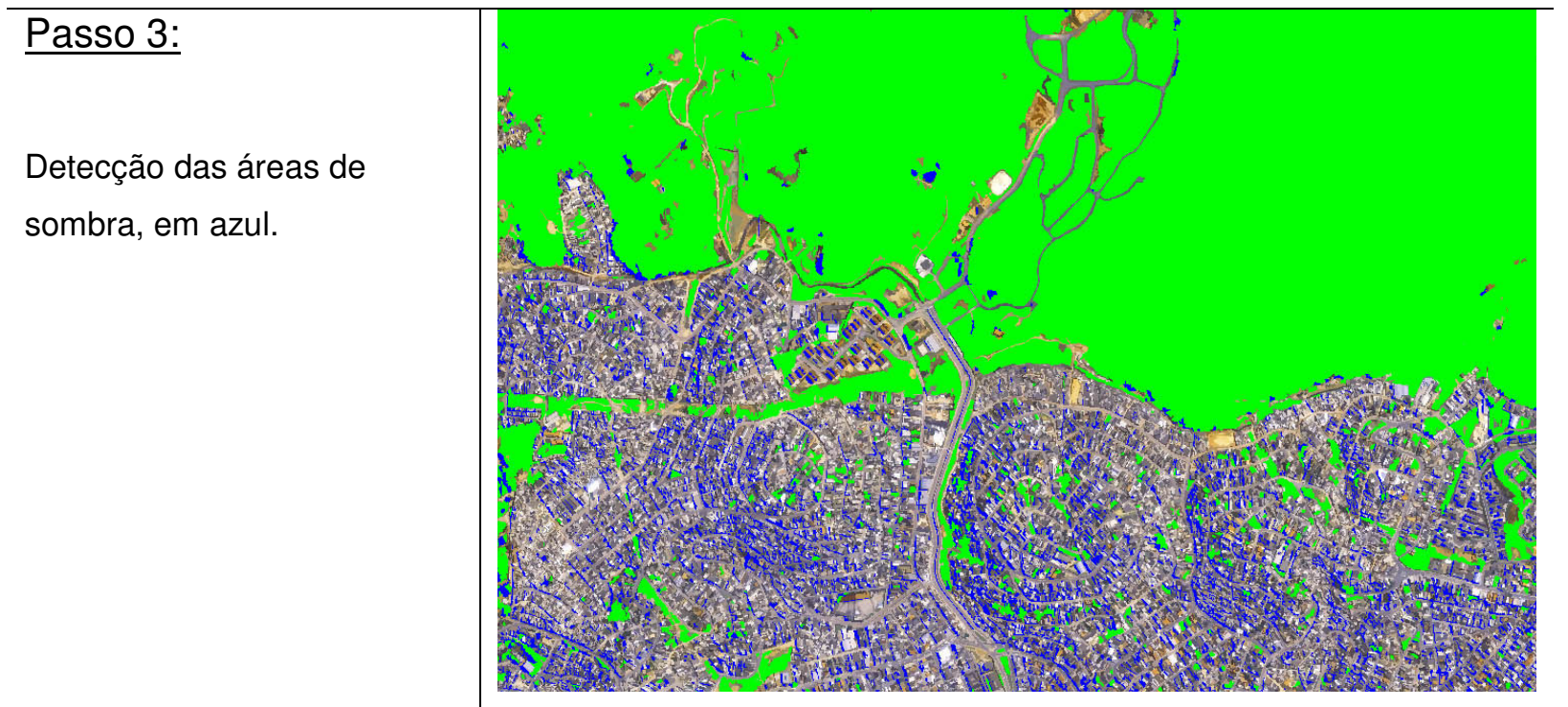

Passo 4:

Detecção das áreas de solo exposto, em amarelo.

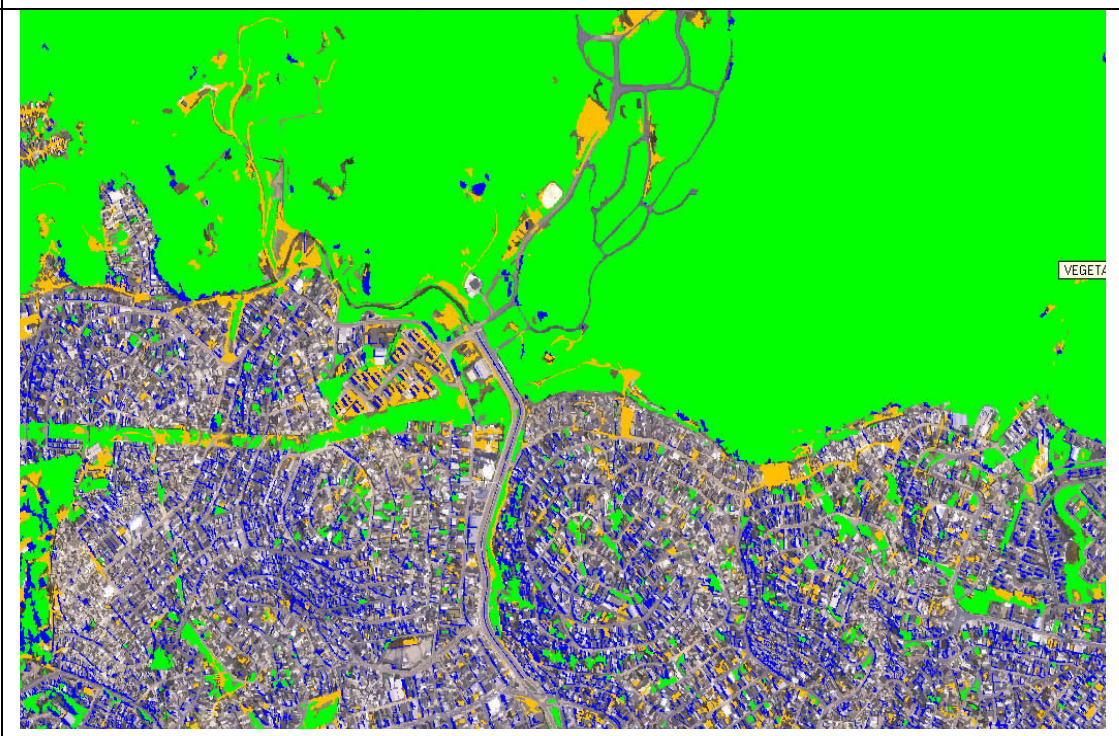

\section{Passo 5:}

Detecção das áreas com cobertura impermeabilizada do solo, em ciano.

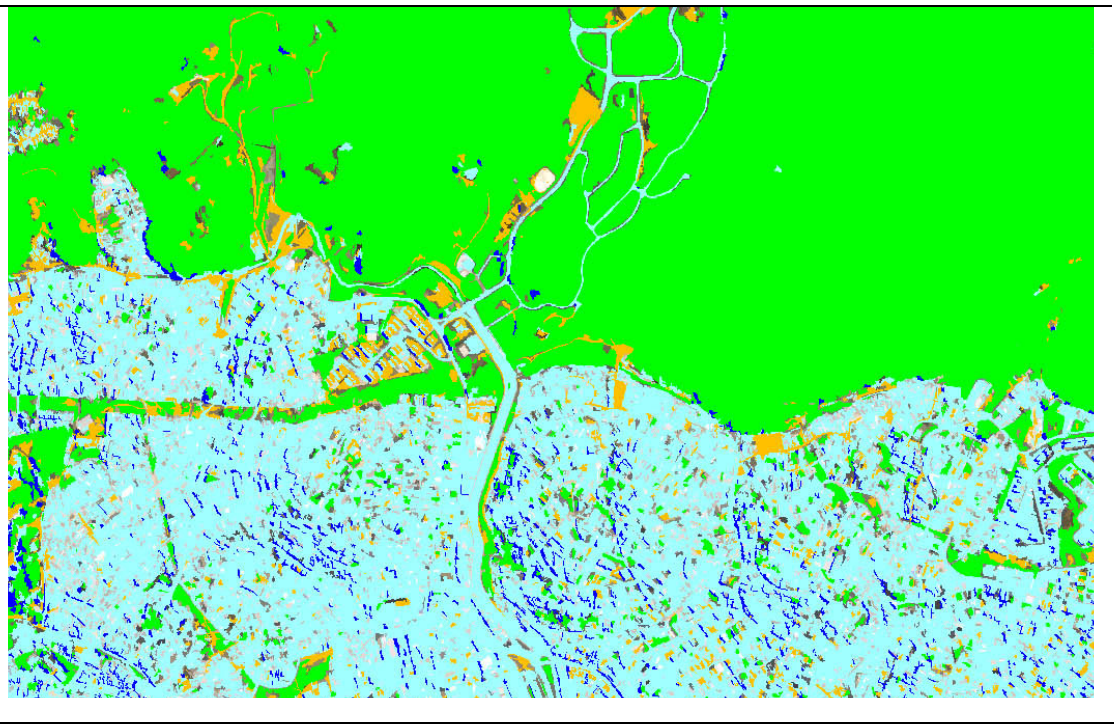




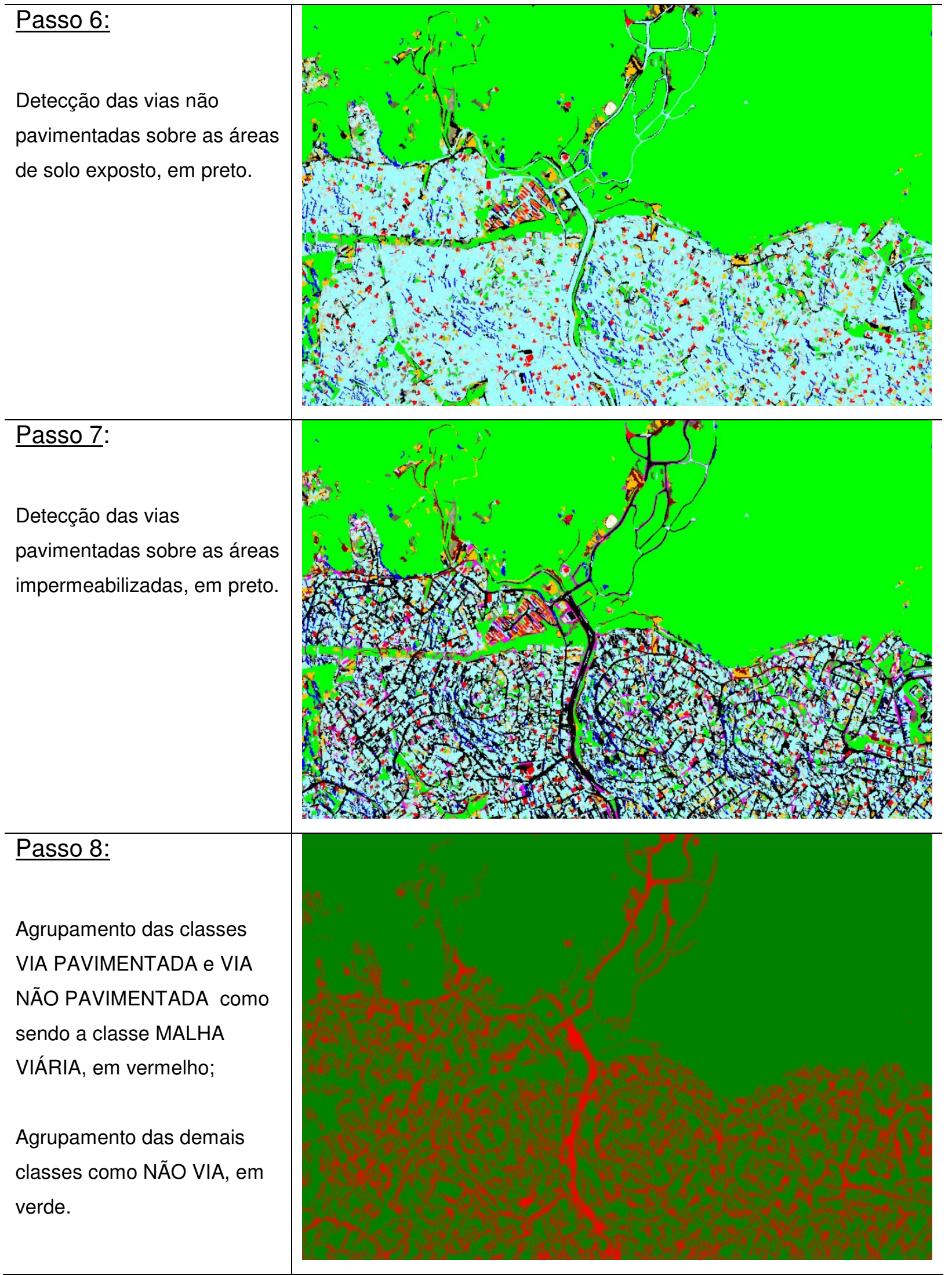




\section{RESULTADOS}

A análise dos resultados obtidos nesse trabalho foi realizada sob três óticas distintas:

- Análise visual: realizada em primeiro plano, onde a malha viária pode ser visualmente identificada;

- Análise da exatidão da classificação: realizada ao compararem os resultados do sistema viário obtido aos polígonos de referência das vias, e

- Avaliação da correspondência linear: seguindo tendências de análises de detecção de sistemas viários, indicadas na literarura, foram realizadas comparações entre os eixos de vias (vias de referência) e os objetos lineares extraídos do sistema viário detectado.

\subsection{ANÁLISE VISUAL DA MALHA VIÁRIA DETECTADA}

Com os primeiros resultados da classificação da malha viária, o primeiro passo para analisar a viabilidade da metodologia foi a visualização e identificação das áreas classificadas, em concordância com as vias presentes na imagem. O ambiente do programa eCognition dispõe de recursos capazes de permitir a visualização simultânea da segmentação e das classes sobre a imagem.

Esses recursos foram fortemente utilizados a medida em que as estratégias e as regras de classificação foram sendo desenvolvidas. Interativamente, foi atribuído sucesso à metodologia ao passo em que a malha viária classificada foi se tornando similar à real malha viária identificada visualmente na imagem. Por fim, os polígonos das áreas classificadas foram exportados para o formato SHP (Esri Shape File), que é um formato de arquivos, de dados vetoriais, amplamente utilizado pela comunidade de 
geoprocessamento. A Figura 42 mostra os polígonos resultantes da detecção da malha viária sobrepostos a imagem IKONOS em uma vista panorâmica virtual.

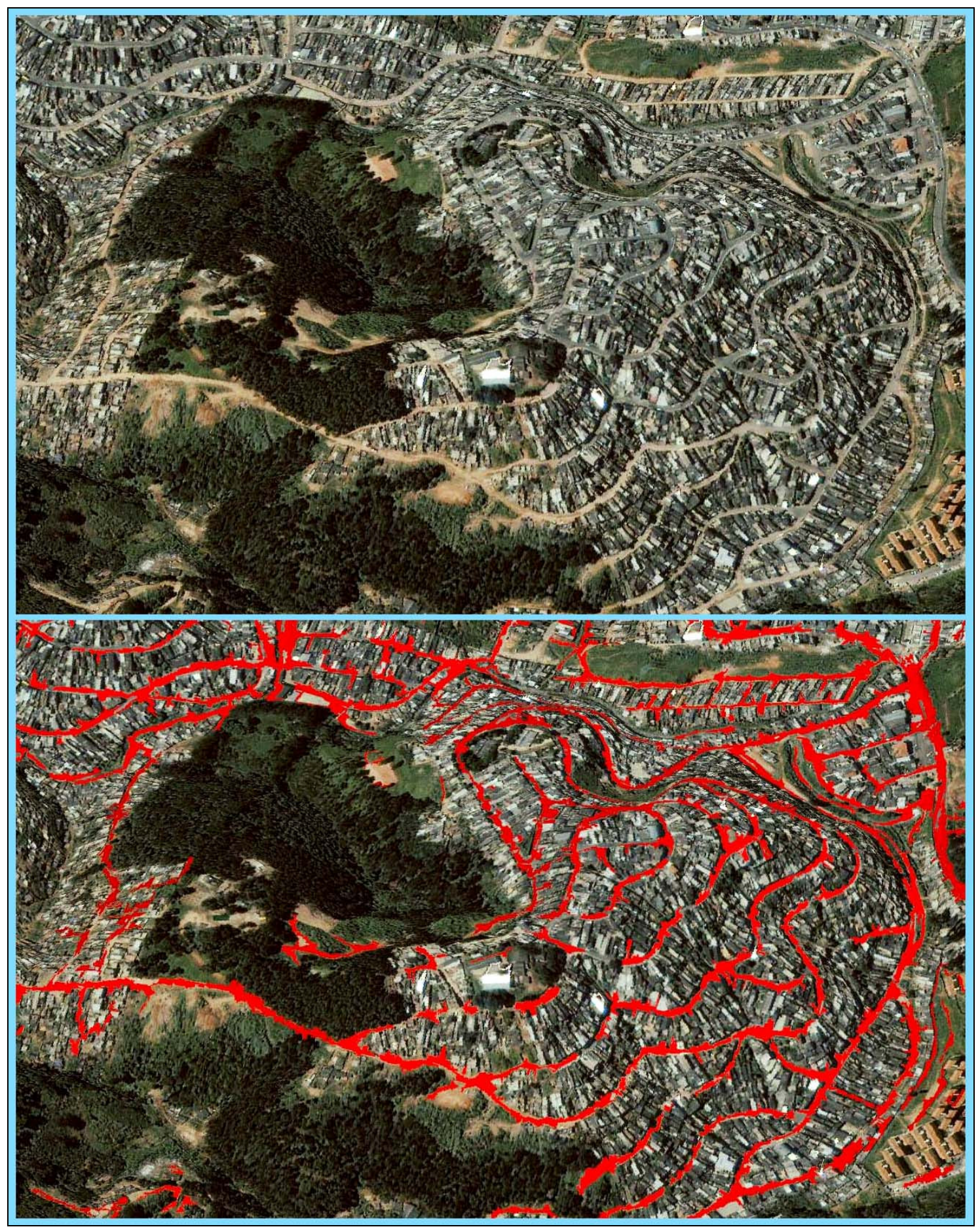

Figura 42 - Visualização tridimensional da imagem IKONOS II e da malha viária resultante da classificação baseada em objetos, sobreposto em vermelho sobre a mesma. 
De posse do modelo digital do terreno da área de estudo, disponibilizado pelo Projeto Cabuçu de Baixo, e do aplicativo ArcScene (módulo utilizado para visualizações e ensaios em dados tridimensionais do programa arcGIS da Esri), os polígonos resultantes da classificação foram carregados em tela e, juntamente com a imagem IKONOS II e as ortofotos, visualizados interativamente em ambiente tridimensional simulado. A imagem IKONOS II e as ortofotos foram estampadas sobre o modelo digital do terreno e os polígonos resultantes da classificação foram estampados sobre ambas. A Figura 42, ilustrada anteriormente, retrata o cenário utilizado na análise visual.

Esse ambiente permitiu a navegação virtual sobre o cenário urbano da área de estudo, sobrepondo a malha viária classificada e, com isso, identificando trechos classificados erroneamente e trechos omissos na classificação. Ainda, nesse ambiente de visualização tridimensional simulada, foi possível perceber o que os dados vetoriais (eixos de logradouros), que seriam utilizados como referência para a etapa de análise dos resultados, não apresentavam qualidade suficientemente adequada para tal função. A excessiva generalização cartográfica dos vetores do mapa de logradouros caracteriza que o produto fora gerado a partir de cartas de escala menor e, supostamente, há muito tempo atrás, devido a total ausência de algumas das vias observadas na periferia da área de estudo.

A análise visual não provê meios de quantificar a exatidão da metodologia, no entanto, contudo fornece com muita segurança bases para qualificá-la. O objetivo da análise visual aqui relatada, foi de fornecer, com base na aderência entre a malha viária classificada e a malha viária presente na imagem, uma estimativa de qualidade para que a manipulação das regras e estratégias de classificação. Em síntese, a qualidade dessa aderência foi verificada para toda a extensão da área de estudo e, uma vez aprovada, partiuse para a quantificação da exatidão dos resultados. 


\subsection{EXATIDÃO DA CLASSIFICAÇÃO}

Analisar a exatidão de uma classificação normalmente envolve a comparação entre os resultados obtidos e as verdadeiras categorias que compõem a cobertura de solo, bem como comparações interclasses, onde são avaliados erros de comissão e erros de omissão em cada uma delas.

A estratégia de análise da exatidão adotada nesse trabalho difere da metodologia padrão empregada para analisar a confiabilidade com que as categorias de cobertura de solo são determinadas no processo de classificação de imagens em sensoriamento remoto. A estratégia de análise aqui considerada compreende a comparação entre polígonos de referência e polígonos extraídos.

As amostras reais das informações não foram tomadas em campo, isto é, não houve visitas em campo para verificar a verdadeira classe de cobertura do solo. A verdade de campo foi obtida a partir da interpretação visual das vias nas ortofotos oriundas do Projeto Cabuçu de Baixo. Em suma, o que se perde com a ausência de amostras reais em campo é a presença de uma informação referencial fidedigna. Isso acarreta a alta dependência dos dados finais da análise para com a base utilizada de referência. A não adequação dos dados às análises de acurácia, fundamentadas na bibliografia, pode acarretar insegurança aos olhos de quem investiga a confiabilidade dos resultados.

Por outro lado, com o emprego dessas ortofotos na composição da base referencial foi a possibilidade de extrair uma referência contínua do sistema viário, ao invés de amostragens discretas, como é tradicionalmente feito em visitas de campo. Também, a diferença de tempo entre a aquisição das imagens IKONOS II (outubro de 2002) e a cobertura aerofotogramétrica responsável pelas ortofotos (setembro de 2003) é de 11 meses, significativamente menor que a diferença de tempo entre a aquisição das imagens IKONOS II e a então amostragem em campo, se realizada no decorrer 
desse trabalho, considerando a alta dinâmica da ocupação urbana nas regiões periféricas.

Ademais, o objetivo principal do trabalho não aborda o mapeamento dos diferentes padrões de cobertura do solo, mas sim a identificação das vias, as quais podem ser facilmente fotoidentificadas em composições coloridas, na porção visível do espectro eletromagnético, como são as ortofotos aqui utilizadas.

\subsubsection{Extração da vias de referência: polígonos}

A alta resolução espacial de $20 \mathrm{~cm}$ das ortofotos permite identificar, com muita segurança, as ruas, os caminhos e os acessos mais estreitos presentes na área de estudo. O processo manual de digitalização executado em tela, denominado heads-up, consiste em vetorizar uma imagem raster, traçando-se diretamente sobre o monitor os elementos de interesse que nele são apresentados. Esse processo foi utilizado nesta etapa do trabalho.

A detecção das vias utilizadas como referência para atestar a acurácia da classificação em imagens, aqui proposta, foi executada manualmente, a partir da interpretação das feições presentes nas ortofotos. A área selecionada para o estudo está inteiramente coberta por 8 ortofotos e parcialmente coberta por 3. Para a área não coberta pelas ortofotos foi utilizada a imagem de satélite, através de uma composição colorida das bandas vermelho, verde e azul, de forma a minimizar diferenças abruptas na interpretação das feições. A Figura 43 ilustra a cobertura da área pelas ortofotos a imagem IKONOS II, bem como a malha viária de referência digitalizada. 


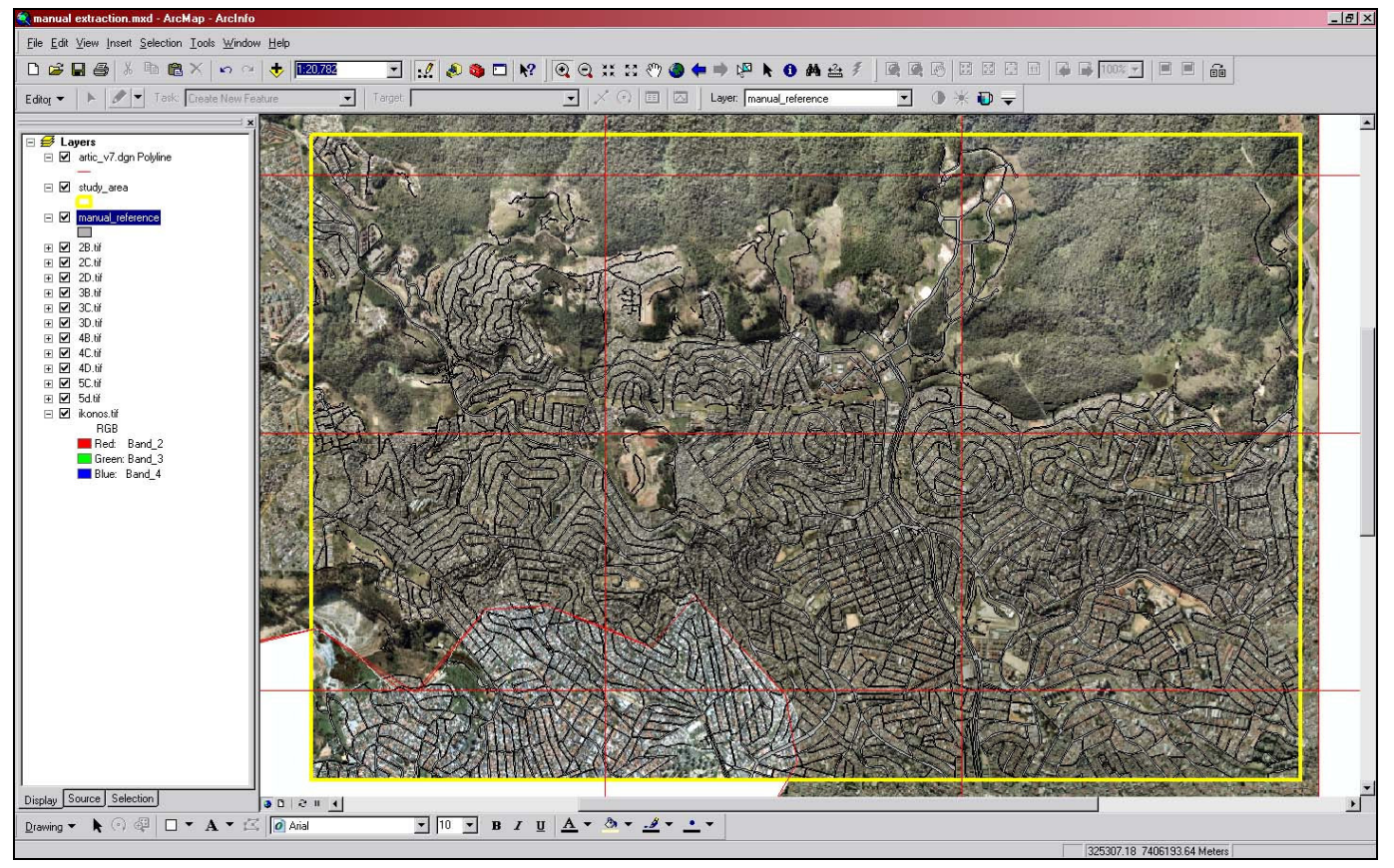

Figura 43 - Cobertura da área de estudo pelas ortofotos do Projeto Cabuçu de Baixo e as respectivas vias de referência digitalizadas em tela.

Todavia, a simplicidade aparente da digitalização em tela deve ser analisada com cautela. A origem da imagem, cartograficamente falando, deve ser conhecida para que não sejam cometidos erros na elaboração de vetores para uso em escalas maiores do que a escala para a qual a imagem fora concebida (para o caso das ortofotos, a escala 1:2.000). Uma outra consideração a ser feita é quanto à padronização da escala de visualização durante a vetorização.

O advento da digitalização em tela trouxe facilidades quanto a manipulação da escala de visualização e isso pode acarretar problemas quanto a padronização do trabalho. É aconselhável manter um padrão de escala de trabalho, padronizando, com isso, a fotointerpretação das feições e o traçado dos vetores propriamente dito. Essa medida permite que sejam produzidos vetores com espaçamentos homogêneos entre os nós e vértices coletados, e que parâmetros como dimensão e área das feições presentes na tela possam ser analisados sem a influência da alteração na escala de apresentação dos mesmos. 
Em sendo as ortofotos produzidas para uso em escala 1:2000, as mesmas foram inseridas no programa ArcGIS. A escala de observação foi ajustada para 1:2000 para que as vias fossem então coletadas na forma vetorial. A Figura 44 ilustra parte da área de estudo e os respectivos polígonos das vias extraídos manualmente.

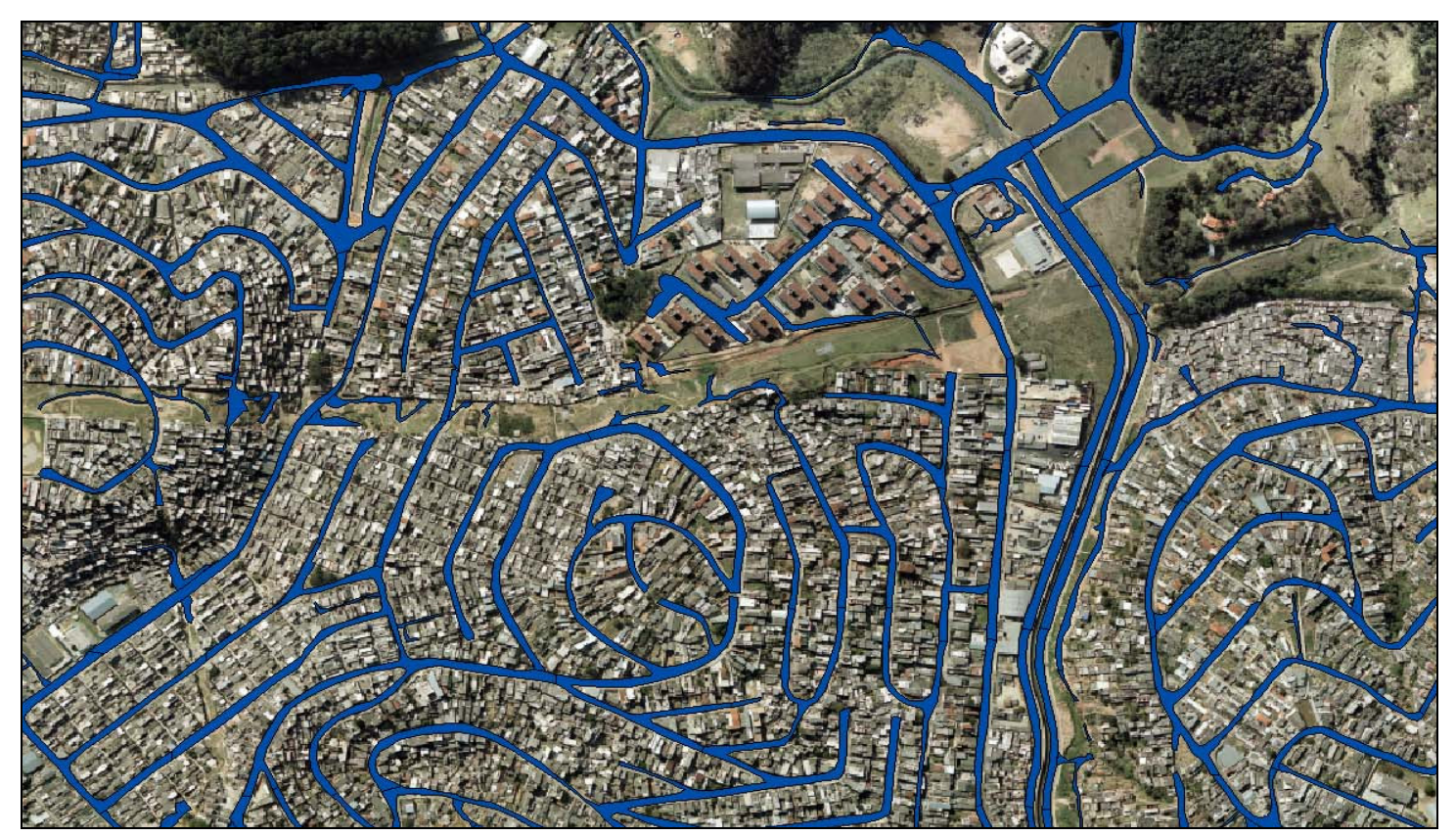

Figura 44 - Vetorização dos polígonos referentes às vias sobre as ortofotos.

\subsubsection{Erros de omissão e comissão}

A estimação da exatidão da metodologia proposta para a detecção do sistema viário foi avaliada pelo cruzamento entre os planos de informação de referência e resultante da classificação. A proposta foi a de promover análises tomando como base a contagem das áreas cobertas ou deixadas de serem cobertas pelos planos de informação vetoriais, numa tentativa de emular a comparação de áreas contada sobre os pixels nas tradicionais análises de exatidão de classificação de imagens em sensoriamento remoto. 
O que motivou essa proposta foi o fato da classe ser singular, ou seja, apenas a malha viária, simplificando muito as comparações. Procurou-se com isso aplicar uma metodologia simples e que fosse efetivamente sensível a ponto de contabilizar pequenas diferenças entre elementos sobrepostos. As análises foram realizadas no programa ArcGIS, mais especificamente recorrendo às ferramentas OVERLAY_ERASE e OVERLAY_INTERSECT, disponíveis nas ferramentas de análises (ANALYSIS TOOLS). As Figura 45 e Figura 46 subseqüentes mostram, sobre as imagens IKONOS II, os respectivos planos de informação básicos que deram origem à análise.

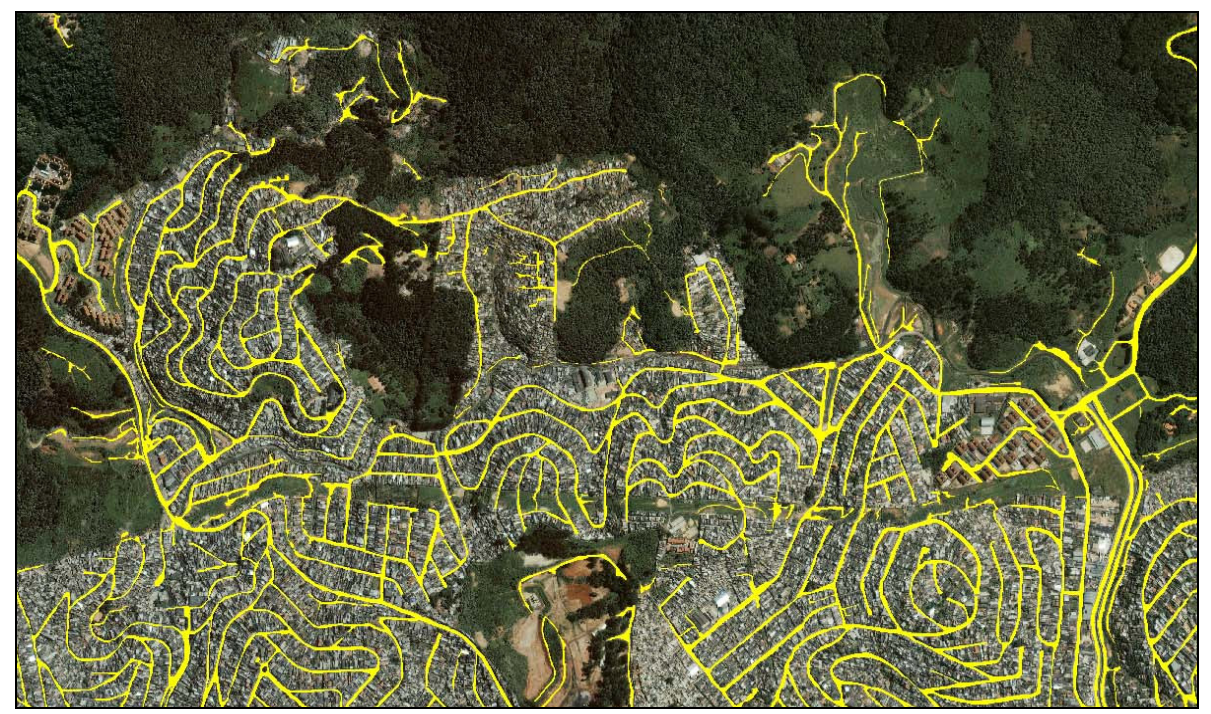

Figura 45 - Polígonos das vias extraídas como referência, sobrepostos na imagem IKONOSII.

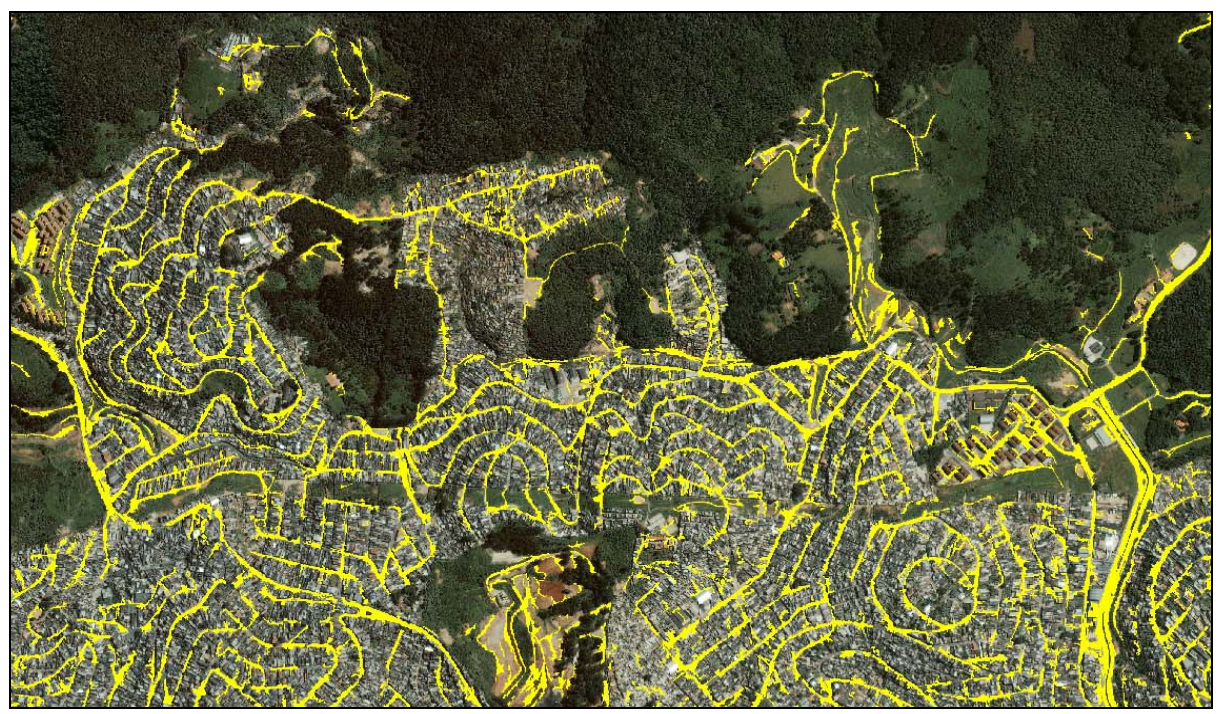

Figura 46 - Polígonos das vias classificadas, sobrepostos na imagem IKONOS II. 
Partindo dos planos de informação básicos previamente ilustrados, foram aplicadas ferramentas de análise espacial entre esses planos, a fim de gerar planos de informação de segunda ordem. Os planos de informação almejados foram:

- CLASSIFICAÇÃO CORRETA: corresponde às áreas das vias corretamente detectadas pela classificação;

- NÃO CLASSIFICADO: corresponde às áreas das vias não detectadas pela classificação;

- CLASSIFICAÇÃO ERRADA: corresponde às áreas diferentes de vias e que foram classificadas como tal.

A ilustração da página seguinte (Figura 47) esquematiza o desdobramento da inter-relação entre os planos de informação que compõem as análises. 
VIA - REFERENCIA

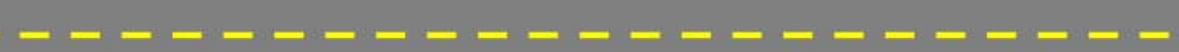

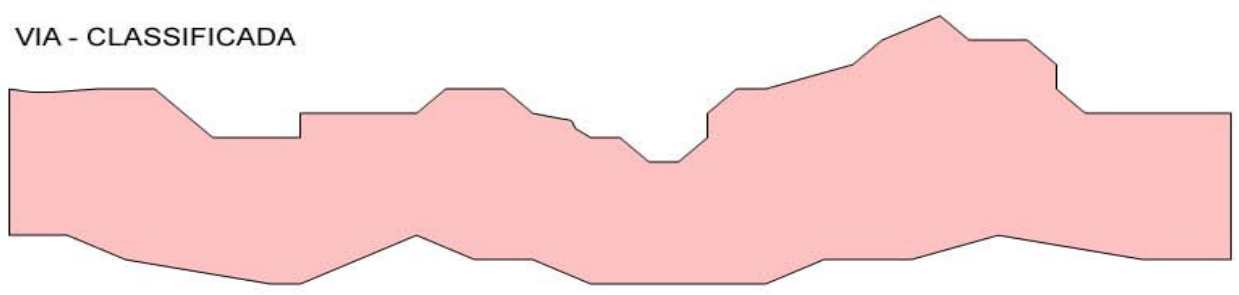

PLANOS DE INFORMACAO SOBREPOSTOS

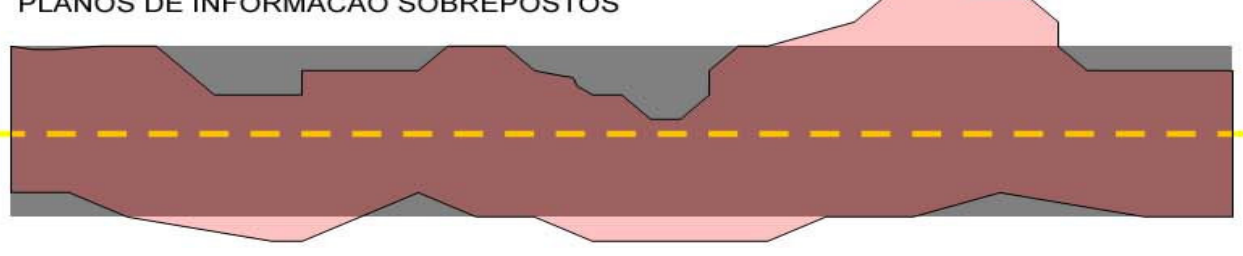

VIAS CLASSIFICADAS CORRETAMENTE

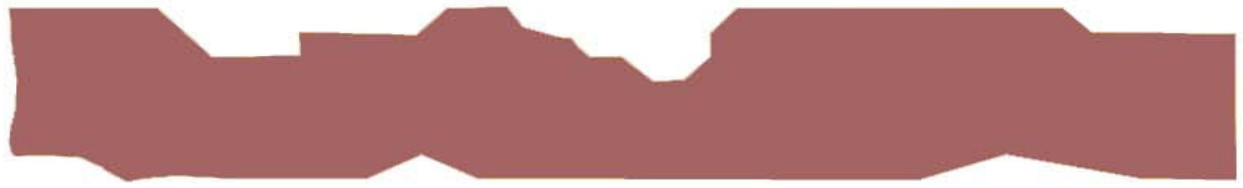

VIAS NAO DETECTADAS NA CLASSIFICACAO
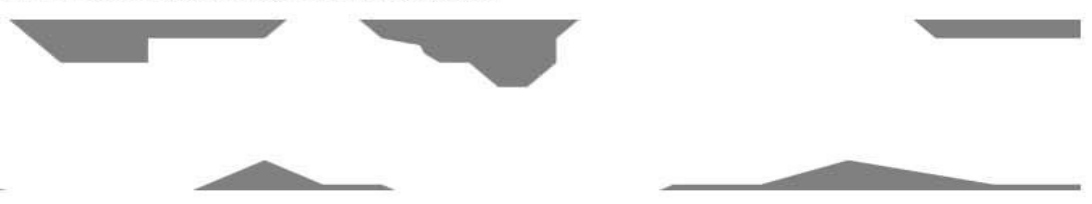

AREAS EXCEDENTES CLASSIFICADAS COMO VIAS
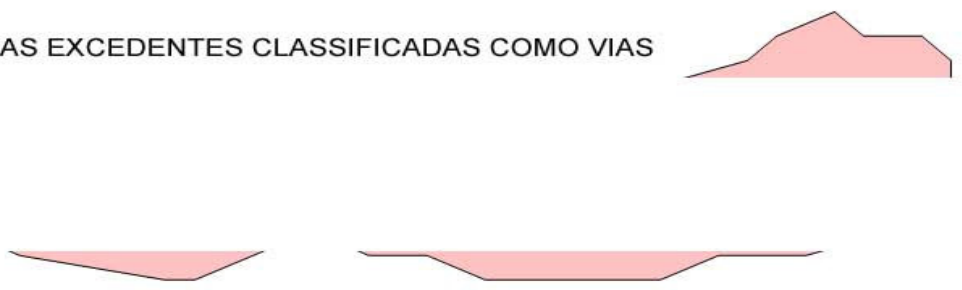

Figura 47 - Ilustração dos planos de informação utilizados na análise. 
Em termos práticos, o cálculo dos planos de informação de segunda ordem utilizou basicamente operações lógicas entre os polígonos correspondentes às vias referenciais e vias classificadas. A intersecção entre os planos de informação REFERÊNCIA e CLASSIFICADO deu origem ao plano CORRETO. Ao subtrair o plano REFERÊNCIA do plano CLASSIFICADO foi gerado o plano ERRADO. Pelo contrário, subtraindo o plano CLASSIFICADO do plano REFERÊNCIA, originou-se o plano NÃO CLASSIFICADO. A Tabela 5 resume os planos e as operações utilizadas para gerá-los.

Tabela 5 - Planos de informação secundários utilizados na análise da exatidão e as operações utilizadas na criação dos mesmos a partir dos planos de informação básicos.

\begin{tabular}{c|ccc}
\hline $\begin{array}{c}\text { Plano de informação } \\
\text { resultante }\end{array}$ & $\begin{array}{c}\text { Operações entre os planos de informação } \\
\text { básicos }\end{array}$ \\
\hline CORRETO & REFERÊNCIA & INTERSECT & CLASSIFICADO \\
\hline NÃO CLASSIFICADO & REFERÊNCIA & ERASE & CLASSIFICADO \\
\hline ERRADO & CLASSIFICADO & ERASE & REFERÊNCIA \\
\hline
\end{tabular}

Os planos de informação secundários CORRETO, NÃO CLASSIFICADO e ERRADO, frutos das operações lógicas entre os planos REFERÊNCIA e CLASSIFICADO são apresentados nas Figura 48, 49 e 50, respectivamente. Vale acrescentar que os planos de informação são complementares, sendo que qualquer semelhança observadas nas figuras mencionadas acima deve ser atribuída a escala de visualização 


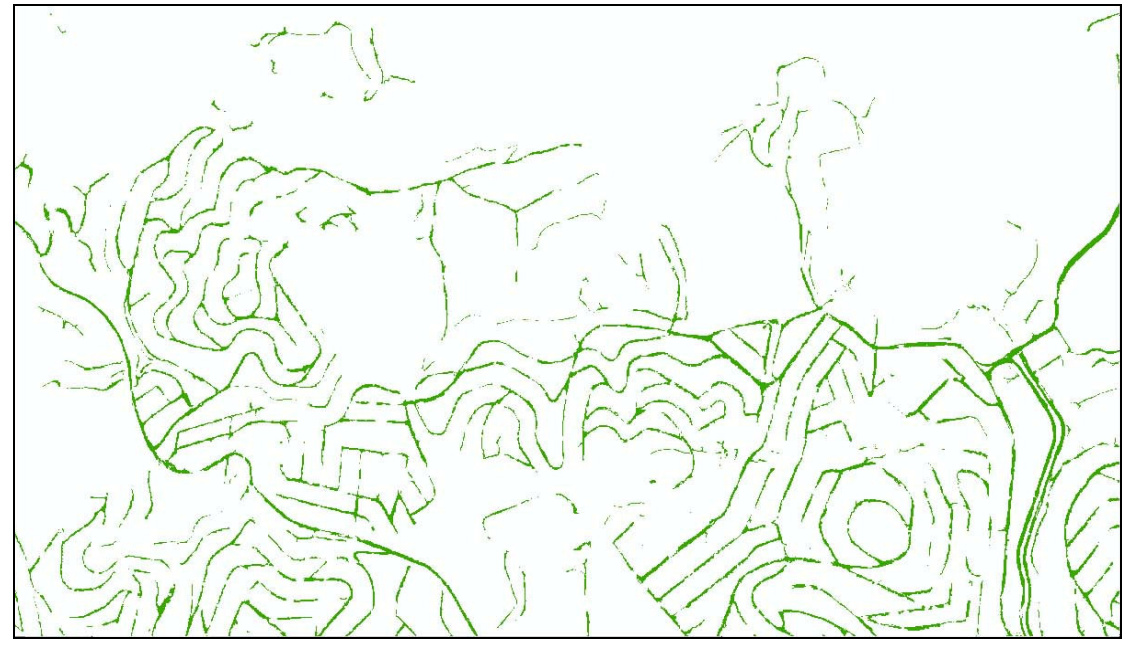

Figura 48 - Classificação correta das vias.

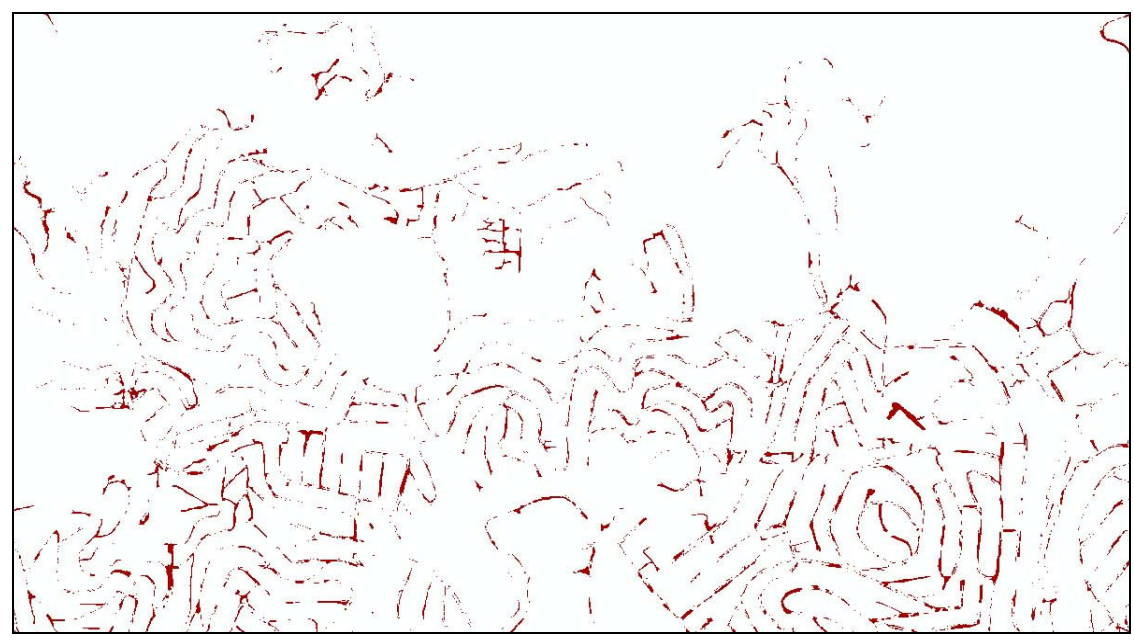

Figura 49 - Trechos das vias de referência que não foram detectados.

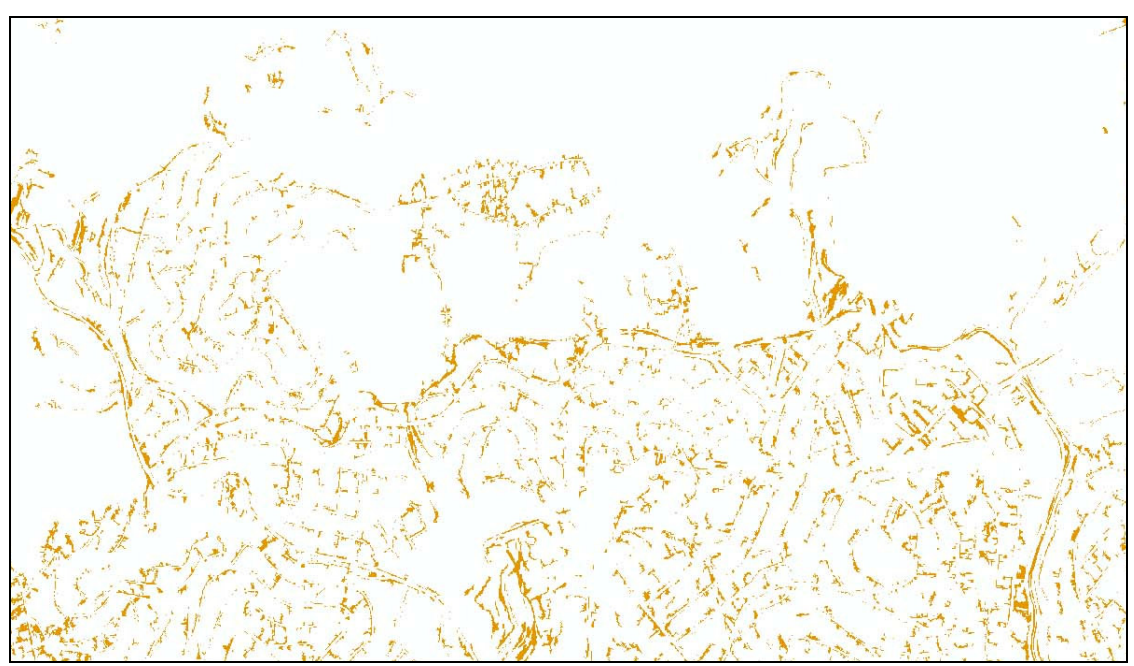

Figura 50 - Feições urbanas classificadas erroneamente como vias. 
De posse dos planos de informação primários e secundários, as respectivas áreas foram extraídas, o que proveu subsídio para que pudessem ser computadas as magnitudes dos erros. Em sensoriamento remoto, para obter a área total das classes, normalmente são somados todos os pixels a ela pertencentes, considerando que a classe é apresentada na forma de uma imagem. Nesse trabalho, as análises foram desenvolvidas sobre dados vetoriais e a respectiva contagem dos pixels pode aqui ser entendida como a contagem das áreas dos polígonos.

Dessa forma, a área total de cada plano de informação foi obtida no programa ArcGIS através da somatória das áreas de cada polígono pertencente ao plano de informação em questão. No aplicativo, esses dados são dispostos em tabelas, o que facilitou substancialmente o processo. Os valores das áreas totais de cada plano de informação estão dispostos na Tabela 6.

Tabela 6 - Planos de informação e suas respectivas áreas utilizados na análise da exatidão.

\begin{tabular}{c|c} 
Plano de informação & Área calculada $\left(\mathrm{m}^{2}\right)$ \\
& \\
\hline REFERÊNCIA & $1.877 .869,3$ \\
\hline CLASSIFICADO & $2.649 .086,2$ \\
\hline CORRETO & $1.212 .053,1$ \\
\hline NÃO CLASSIFICADO & $665.816,3$ \\
\hline ERRADO & $1.437 .086,1$ \\
\hline
\end{tabular}

As áreas calculadas dos planos de informação foram então utilizadas na avaliação da acurácia e dos erros de comissão e omissão. As equações (17), (18) e (19) descrevem o desenvolvimento desses cálculos. 


$$
\begin{gathered}
\text { exatidão_geral }=\frac{\text { CORRETO }}{\text { REFERE } \hat{E} N C I A} \\
\text { erro_de_comissâo }=\frac{\text { REFERÊNCIA }- \text { CORRETO }}{R E F E R E \hat{E} N C I A} \\
\text { erro_de_comissâo }=\left(\frac{\text { CLASSIFICADO }- \text { CORRETO }}{\text { REFERE ECIA }}\right)
\end{gathered}
$$

A exatidão geral do processo de classificação foi de $64,5 \%$. Em outras palavras, $64,5 \%$ das áreas cobertas por vias na imagem foram detectadas pela metodologia. Os erros de omissão (objetos sabidamente de uma classe, mas classificados em outra) e de comissão (objetos sabidamente de outras classes classificados como sendo de uma determinada classe) foram de $35,5 \%$ e $76,5 \%$, respectivamente.

Contrariando a expectativa obtida na análise visual, os valores aqui encontrados mostraram-se, a princípio, inadequados para afirmar a eficácia da metodologia. Por serem feições lineares, as vias geram polígonos estreitos e em muitos casos de dimensões limitadas. A análise visual, em se tratando de um processo cognitivo, nos força a interpretar o resultado da classificação como sendo o próprio sistema viário. Intuitivamente desprezam-se com isso as pequenas áreas detectadas em excesso e ignoram-se as pequenas porções das vias não detectadas. Em números, a somatória dessas pequenas áreas implica em valores significativos, como os erros de omissão e comissão apresentados. 


\subsection{AVALIAÇÃO DA CORRESPONDÊNCIA LINEAR DA MALHA VIÁRIA DETECTADA}

A boa aderência entre os polígonos resultantes da vias classificadas para com as vias reais demonstrou que a metodologia apresentou qualidade nos resultados. No entanto, ao quantificar a exatidão da metodologia recorrendo a comparações entre as áreas classificadas e as áreas de referência, observou-se que os erros apresentaram altos valores, em especial os erros atribuídos a classificação das demais feições urbanas como sendo vias. Nesse sentido, a comparação entre linhas ao invés de polígonos passou a ser a solução mais indicada.

Para a análise linear o programa L-CAT (item 3.6) foi selecionado por conter as ferramentas necessárias às análises lineares comparativas, descritas anteriormente (item 2.11). A extração das linhas de referência e das linhas resultantes da classificação, bem como o desenvolvimento da análise linear comparativa são descritas nos itens subseqüentes.

\subsubsection{Extração das vias de referência: linhas}

De forma análoga à extração das vias de referência apresentada no item 5.2.1, a extração das linhas centrais das vias (eixos) foi executada manualmente sobre o mesmo conjunto de ortofotos. Assim como no processo anterior, foi adotada a vetorização manual sobre as ortofotos, porém coletando os eixos das vias. Esse procedimento foi realizado no programa arcGIS.

No entanto, considerando que os eixos das vias correspondem a um modelo simplificado da malha viária, a vetorização não necessitou do mesmo rigor em detalhes que a etapa anterior, quando o objetivo foi a fiel representação dos polígonos referentes às ruas, vielas e avenidas para 0 cálculo das áreas. Em outras palavras, para a representação linear do sistema viário pôde ser empregado o conceito de generalização, o que permitiu a 
simplificação da representação geométrica das feiçoes coletadas. Para isso, foi fixada a escala de observação no arcGIS em 1:2.000, a fim de que fosse mantida a homogeneidade quanto a interpretação dos detelhes presentes na imagem, bem como a homogeneidade quanto ao espaçamento e detalhamento no traçado das linhas de referência coletadas. Nesse processo, total atenção foi dada para que as linhas percorressem a região central das vias.

A Figura 51 ilustra a mesma área vista anteriormente na Figura 44, porém com as linhas centrais sobrepostas sobre as ortofotos. A ilustração seguinte (Figura 52) apresenta uma visualização mais detalhada da vetorização em tela das linhas centrais de referência sobre a ortofoto.

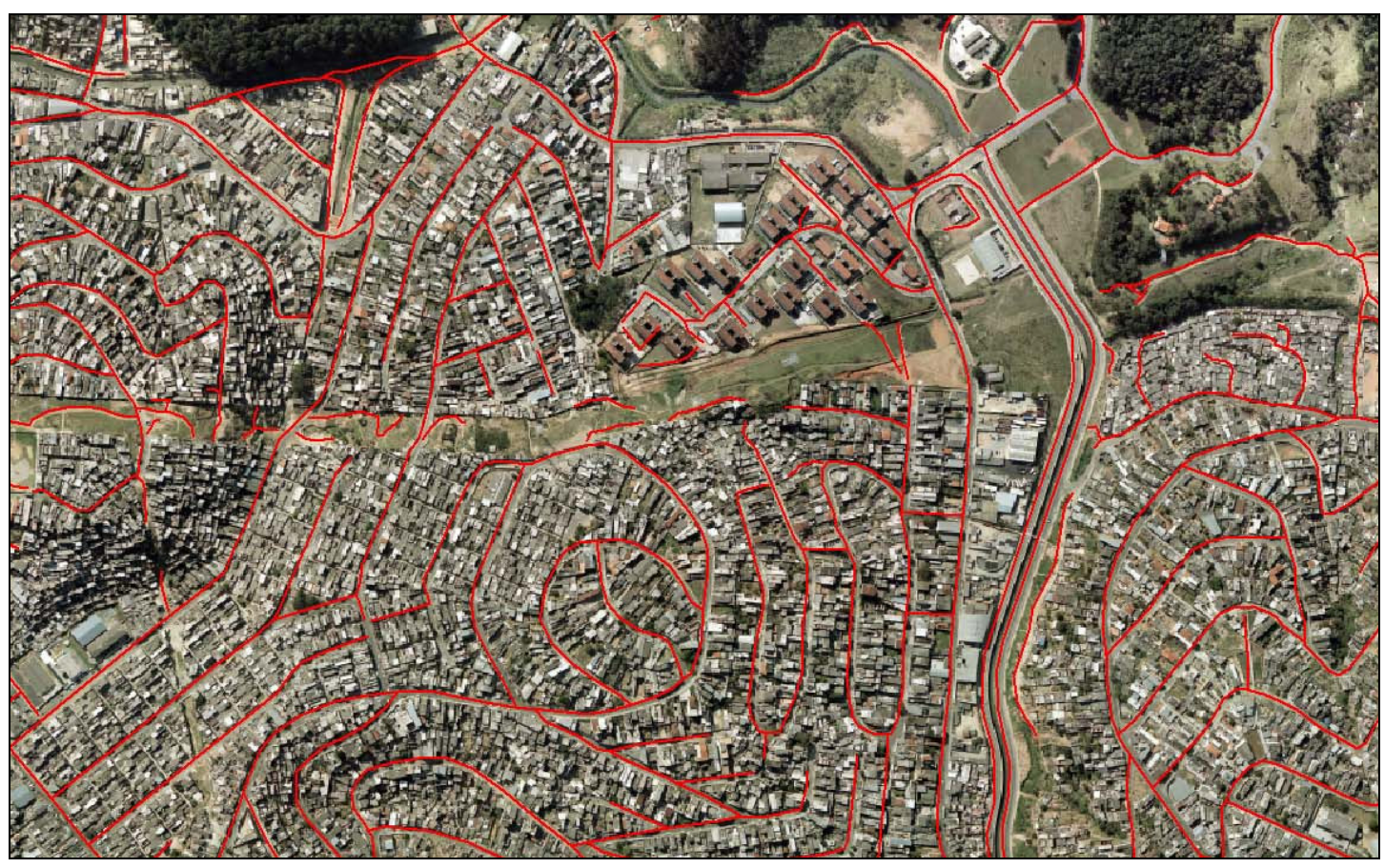

Figura 51 - Vetorização dos eixos das vias sobre as ortofotos. 


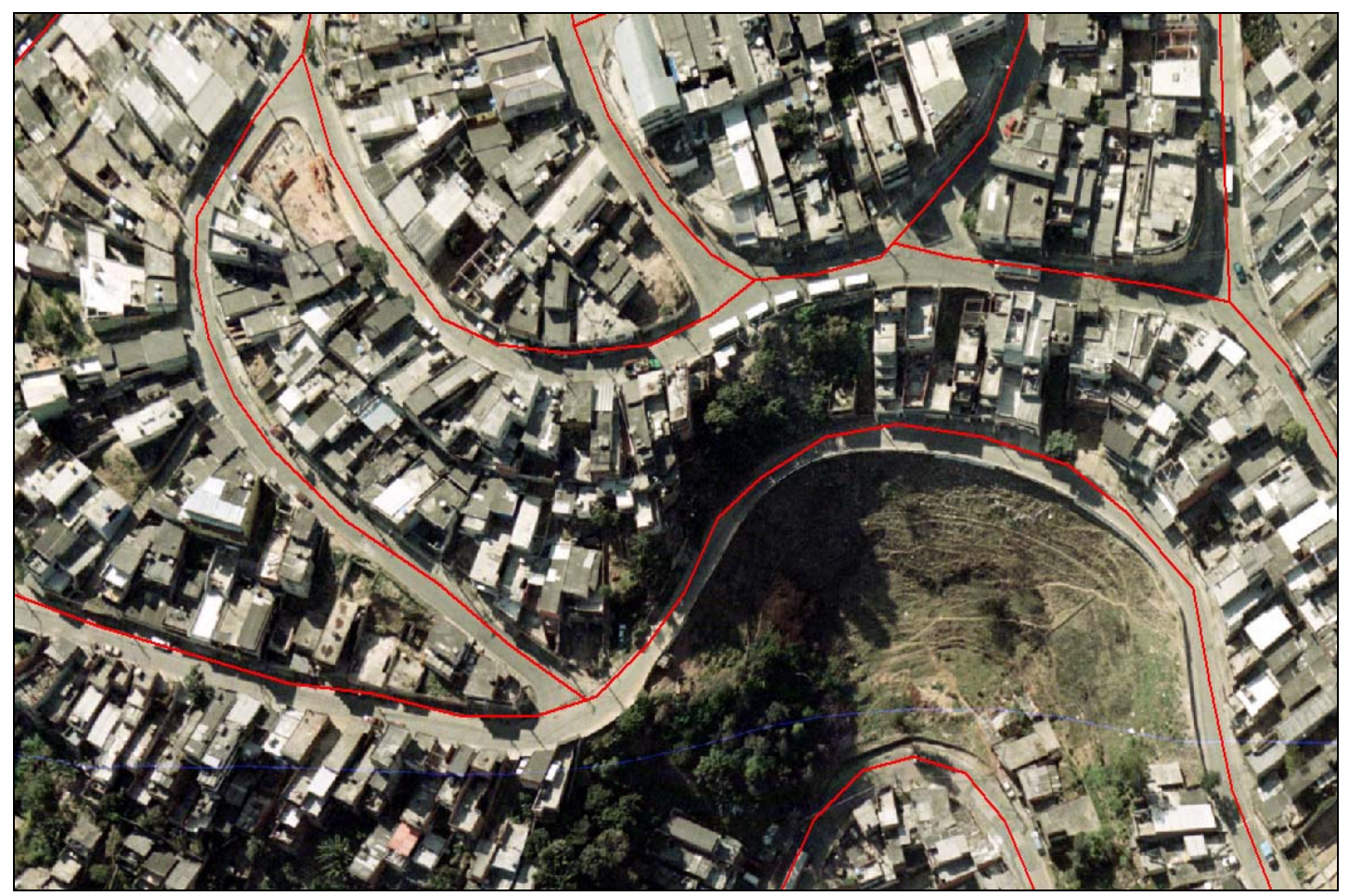

Figura 52 - Detalhe da vetorização dos eixos das vias sobre as ortofotos observados em escala 1:2.000.

\subsubsection{Linearização dos polígonos detectados}

Para que o resultado da classificação fosse obtido na forma linear, optou-se inicialmente em utilizar a esqueletonização dos objetos, ferramenta essa disponível no programa eCognition. Os primeiros resultados, porém, desmotivaram sua continuidade. Os esqueletos (linhas mediais extraídas da estrutura geométrica dos segmentos) eram descontínuos, pois o programa os calcula de forma independente para cada objeto. Como solução, a união dos segmentos conectados gerando objetos macro foi avaliada, porém os esqueletos gerados desses objetos maiores não retratavam a realidade das linhas centrais inicialmente observadas.

A solução então proposta para a obtenção dos eixos das vias foi baseada no afinamento dos elementos, recorrendo a operadores de morfologia matemática, conhecidos aos usuários de processamento de imagens digitais. Para tanto foram utilizadas as ferramentas de processamento de imagens 
digitais do programa Matlab. A principal vantagem oferecida pelo Matlab é sua simplicidade quanto ao emprego de funções já existentes, bem como a facilidade para implementação de rotinas. Como desvantagem, processar imagens no Matlab em um computador com arquitetura PC (Personal Computer) convencional acaba limitando o trabalho à pequenas áreas, uma vez que seu desempenho fica comprometido significativamente ao processar imagens "pesadas".

Como medida inicial, para que as áreas classificadas fossem afinadas por operadores morfológicos de processamento de imagens digitais, os polígonos resultantes da classificação tiveram que ser convertidos para o formato raster. Essa conversão foi realizada diretamente no programa eCognition. Fora então selecionada a opção de exportação da classe MALHA VIARIA em imagem de formato GEOTIFF, que corresponde a uma imagem do padrão TIFF, porém contendo informações quanto ao posicionamento geográfico e sistema de projeção e referência cartográfica. Vale ressaltar que essas informações geográficas da imagem foram ignoradas quando a mesma foi carregada no programa Matlab.

No entanto, os operadores morfológicos do Matlab foram desenvolvidos para trabalhar em imagens binárias. Desta forma, antes de se iniciar o afinamento dos polígonos, uma nova imagem binária foi produzida no Matlab a partir da imagem original resultante da classificação. Essa imagem binária contém apenas os elementos pertencentes as vias e os elementos de fundo.

O passo seguinte foi à obtenção da imagem final contendo somente as linhas. O resultado do afinamento direto dos polígonos não foi satisfatório, pois continha excessivos ruídos, elementos desconectados e saliências (denominadas spur "espinho" no Matlab). A solução foi empregar gradativamente funções capazes de minimizar esses inconvenientes. A Tabela 7 apresenta a seqüência de comandos adotados para a obtenção das linhas resultantes da classificação. 
Tabela 7 - Seqüência de comandos do programa Matlab utilizados no afinamento dos polígonos classificados como malha viária.

\begin{tabular}{c|l|lc}
\hline Passo & \multicolumn{1}{|c|}{ Linha de comando } & \multicolumn{1}{|c}{ Descrição } \\
\hline 1 & A = imread('results.tif') & Leitura da imagem dos polígonos classificados \\
\hline 2 & A1 im2bw(A, 0.5); & Gera imagem binária & \\
\hline 3 & A2 = BWMORPH(A1,'clean',inf); & Remover pixels externos isolados & áreas \\
\hline 4 & A3 = BWMORPH(A2,'fill', inf); & Remove pixels internos isolados & pontos \\
\hline 5 & A4 = BWMORPH(A3,'dilate'); & $\begin{array}{l}\text { Dilatação para unir pequenas } \\
\text { desconectadas }\end{array}$ \\
\hline 6 & A5 = BWMORPH(A4,'close',inf); & Completar áreas abertas e preservar conexões \\
\hline 7 & A6 = BWMORPH(A5,'thin',inf); & Refinar áreas até espessura de 1 pixel. \\
\hline 8 & A7 = BWMORPH(A6,'dilate',3); & $\begin{array}{l}\text { Dilatar linhas para remover } \\
\text { desconectados }\end{array}$ \\
\hline 9 & A8 = BWMORPH(A7,'thin',inf); & Refina novamente as linhas & \\
\hline 10 & A9 = BWMORPH(A8,'spur',10); & Remover pontas e espinhos das linhas \\
\hline 11 & imwrite(A9,'extracted.tif'); & Salva imagem em formato TIFF & \\
\hline
\end{tabular}

Vale ressaltar que, por se tratar de uma área relativamente pequena, o processo de afinamento dos polígonos da área de estudo pode ser desenvolvido no Matlab sem maiores problemas. A Figura 53 ilustra as linhas processadas e os polígonos originais sobrepostos. 


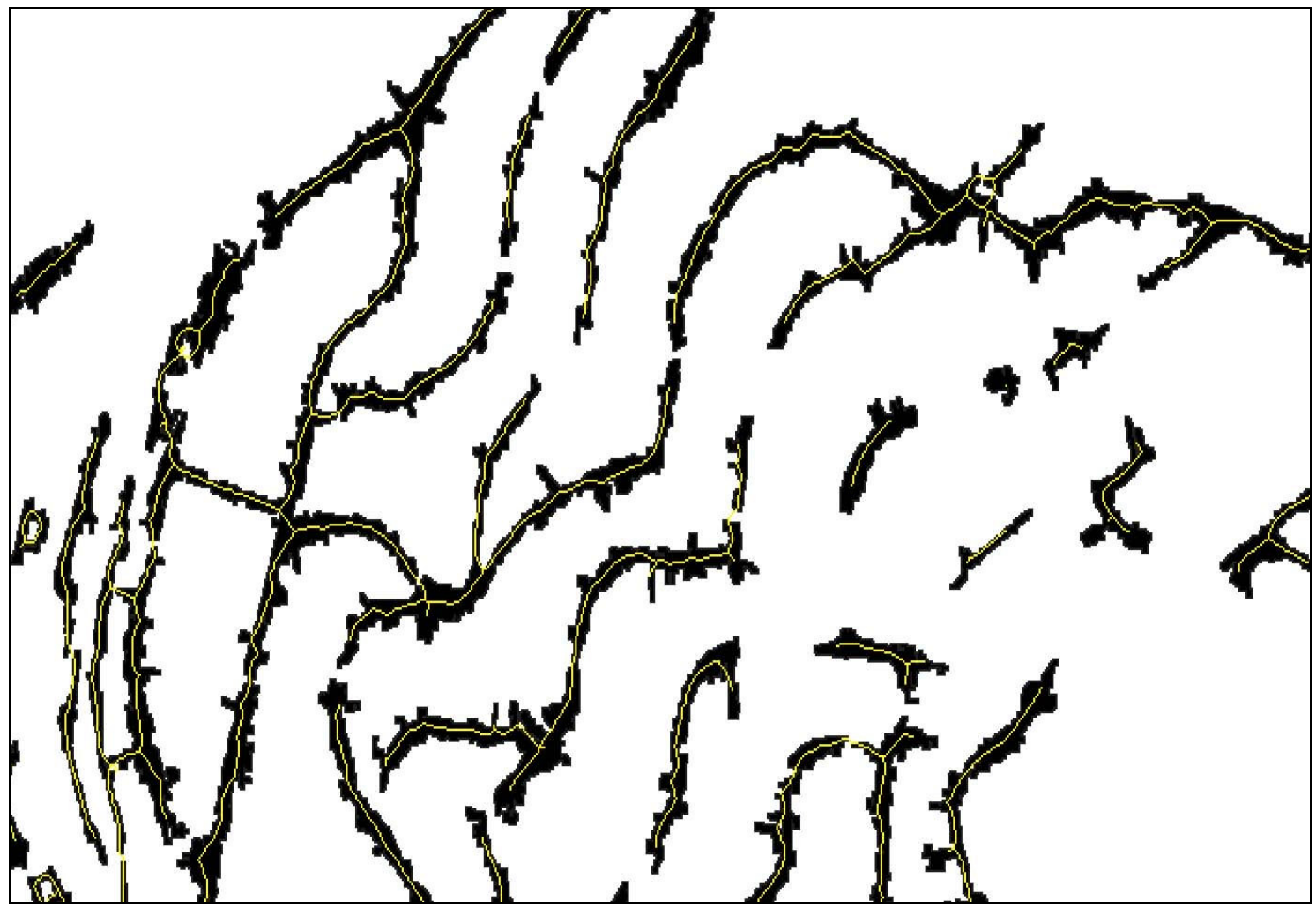

Figura 53 - Linhas resultantes (em branco) do afinamento dos polígonos (em preto) resultante do processo de classificação das vias.

De forma análoga à análise visual dos polígonos vista anteriormente para atestar a qualidade da malha viária detectada, as linhas de referência e classificadas foram carregadas e sobrepostas simultaneamente para atestar a aderência através da visualização tridimensional projetada (Figura 54). 


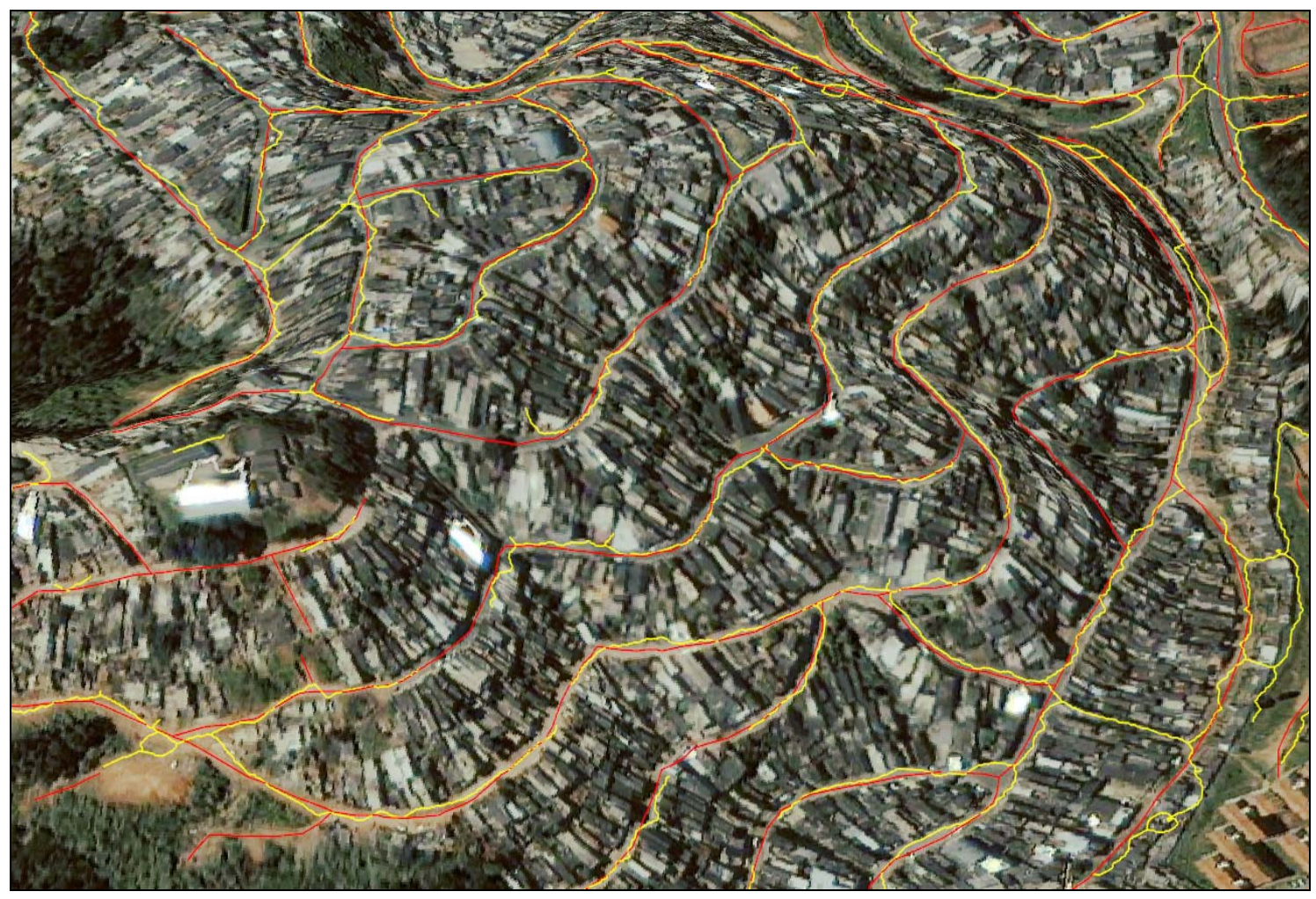

Figura 54 - Visualização tridimensional das linhas de referência e das linhas resultantes da classificação sobre a imagem IKONOS.

\subsubsection{Análise da correspondência linear}

Conforme mencionado anteriormente, o desenvolvimento da análise linear comparativa foi executado a partir do programa L-CAT, que toma como base a comparação entre buffers calculados a partir das linhas de referência e das linhas extraídas. O L-CAT os compara na forma matricial, razão pela qual os elementos lineares que alimentam o programa são inicialmente convertidos para raster. A Figura 55 mostra uma visão geral do programa L-CAT. 


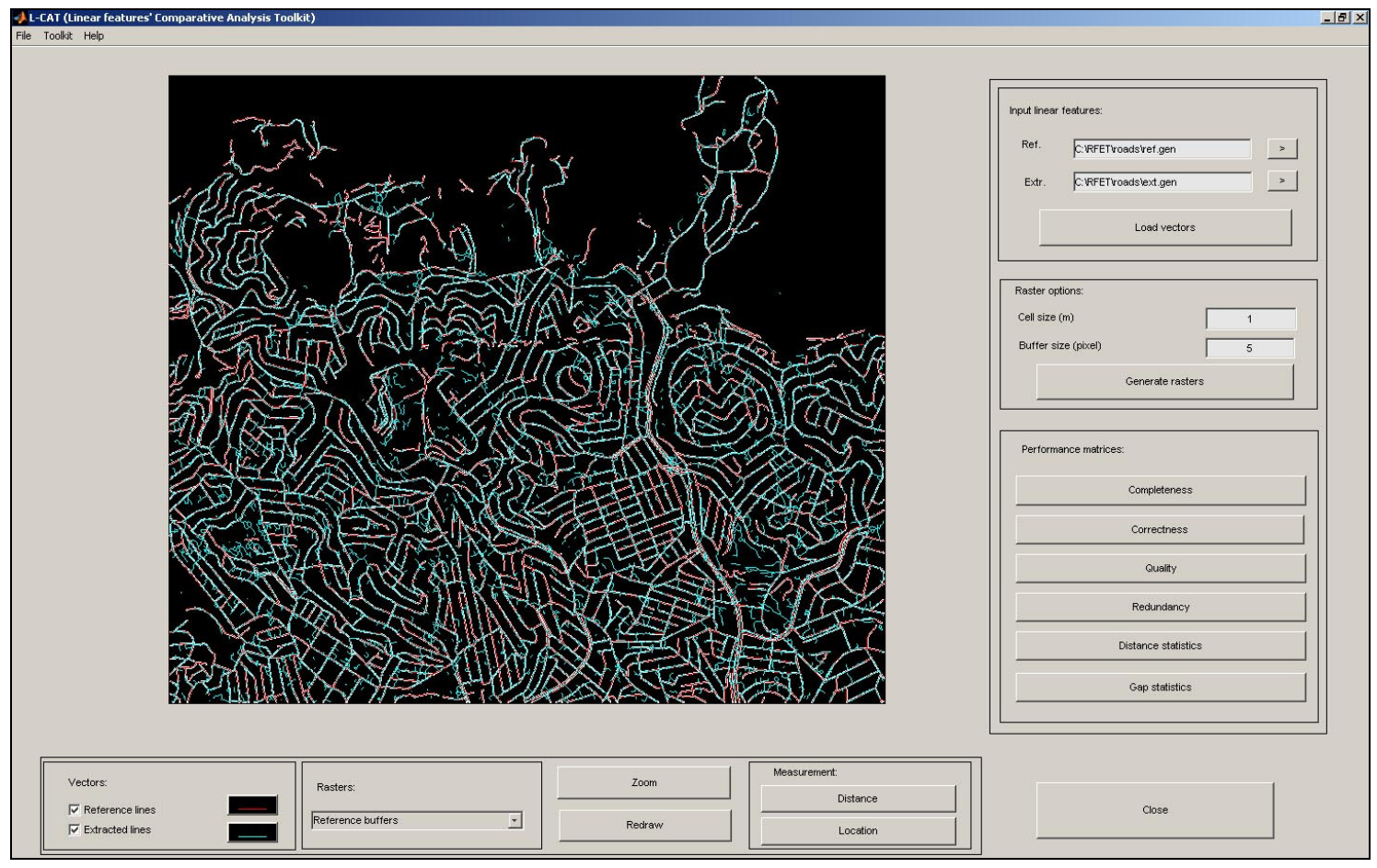

Figura 55 - Visão geral do programa L-CAT utilizado na análise linear comparativa.

Para o desenvolvimento dessa análise, foram processadas diversas configurações de resolução e abrangência dos buffers. Essa amplitude de dados processados teve como objetivo envolver pequenas e grandes dimensões, respectivamente aquém e além da espessura média das vias na área de estudo, que observadas e mensuradas nas ortofotos, concentram-se próximas a 9 metros. A Tabela 8 contém os resultados de processamentos utilizando resoluções entre 1 e 4 pixels e buffers entre 2 e 6 metros.

Embora a gama de parâmetros coletados tenha sido alta, a análise linear foi concentrada nas combinações entre resolução espacial e abrangência do buffer capazes de produzir resultados próximos a espessura média das vias. A preferência quanto a resolução foi por 1 pixel, de forma a manter a coerência com a resolução espacial das imagens IKONOS utilizadas. Para essa resolução, os buffers de 4 e 5 pixels correspondem à espessura desejada. 
Tabela 8 - Resultados do programa L-CAT abrangendo resoluções entre 1 e 4 pixels e buffers entre 2 e 6 metros

\begin{tabular}{|c|c|c|c|c|c|}
\hline Completeza (\%) & 2 pixels & 3 pixels & 4 pixels & 5 pixels & 6 pixels \\
\hline $1 \mathrm{~m}$ & 42.82 & 57.31 & 64.66 & 71.05 & 74.18 \\
\hline $2 \mathrm{~m}$ & 62.99 & 73.61 & 78.05 & 82.05 & 84.41 \\
\hline $3 \mathbf{m}$ & 71.96 & 79.98 & 83.94 & 87.54 & 89.93 \\
\hline $4 m$ & 77.06 & 84.12 & 87.99 & 91.59 & 93.64 \\
\hline Precisão (\%) & 2 pixels & 3 pixels & 4 pixels & 5 pixels & 6 pixels \\
\hline $1 \mathrm{~m}$ & 44.03 & 55.42 & 61.8 & 67.17 & 70.15 \\
\hline $2 \mathrm{~m}$ & 63.15 & 70.71 & 74.65 & 78.3 & 80.65 \\
\hline $3 \mathbf{m}$ & 70.8 & 76.86 & 80.47 & 84.45 & 87.31 \\
\hline $4 m$ & 75.26 & 80.99 & 85.09 & 89.58 & 92.69 \\
\hline Redundância (\%) & 2 pixels & 3 pixels & 4 pixels & 5 pixels & 6 pixels \\
\hline $1 \mathrm{~m}$ & 6.36 & 13.09 & 14.44 & 15.68 & 15.64 \\
\hline $2 \mathbf{m}$ & 2.75 & 6.69 & 7.16 & 7.39 & 7.27 \\
\hline $3 \mathbf{m}$ & 0.82 & 3.1 & 3.47 & 2.82 & 2.17 \\
\hline $4 m$ & 1.98 & 0.57 & 1.01 & 2.12 & 3.29 \\
\hline Qualidade & 2 pixels & 3 pixels & 4 pixels & 5 pixels & 6 pixels \\
\hline $1 \mathrm{~m}$ & 27.09 & 37.78 & 44.57 & 51.02 & 54.7 \\
\hline $2 \mathrm{~m}$ & 45.72 & 55.65 & 60.94 & 66.13 & 69.54 \\
\hline $3 \mathbf{m}$ & 55.39 & 64.08 & 69.41 & 75.16 & 79.38 \\
\hline $4 m$ & 61.71 & 70.3 & 76.31 & 82.91 & 87.37 \\
\hline Distância (m) & 2 pixels & 3 pixels & 4 pixels & 5 pixels & 6 pixels \\
\hline $1 \mathrm{~m}$ & 1 & 1.33 & 1.56 & 1.81 & 1.97 \\
\hline $2 \mathrm{~m}$ & 1.68 & 2.07 & 2.34 & 2.66 & 2.91 \\
\hline $3 \mathbf{m}$ & 2.16 & 2.61 & 2.98 & 3.49 & 4.31 \\
\hline $4 m$ & 2.58 & 3.17 & 3.69 & 4.43 & 5.04 \\
\hline Lacuna média (m) & 2 pixels & 3 pixels & 4 pixels & 5 pixels & 6 pixels \\
\hline $1 \mathrm{~m}$ & & memória & uficiente $\mathrm{p}$ & cálculo & \\
\hline $2 \mathrm{~m}$ & 20.88 & 23.84 & 27.2 & 28.26 & 28.01 \\
\hline $3 \mathbf{m}$ & 23.22 & 27.02 & 28.07 & 27.51 & 27.47 \\
\hline $4 \mathrm{~m}$ & 26.38 & 28.48 & 28.48 & 28.88 & 30.51 \\
\hline Lacunas/ Km & 2 pixels & 3 pixels & 4 pixels & 5 pixels & 6 pixels \\
\hline $1 \mathrm{~m}$ & & memória & uficiente $\mathrm{p}$ & cálculo & \\
\hline $2 \mathbf{m}$ & 17.65 & 11.07 & 8.07 & 6.35 & 5.57 \\
\hline $\mathbf{3} \mathbf{m}$ & 12.08 & 7.44 & 5.72 & 4.53 & 3.67 \\
\hline $4 \mathrm{~m}$ & 8.7 & 5.58 & 4.22 & 2.91 & 2.09 \\
\hline
\end{tabular}

E uma analogia a outros trabalhos de detecção de vias a partir de imagens de satélite descritos na literatura, os principais parâmetros de correspondência linear utilizados aqui foram a completeza e a precisão. Ainda, as análises dos resultados do presente trabalho consideraram também as estatísticas de lacunas calculadas pelo L-CAT.

Entretanto, ao utilizar resolução de 1 pixel, o programa L-CAT acusou erro no processamento das lacunas (GAP STATISTICS), 
correspondente a insuficiência de memória disponível ao cálculo. Como alternativa, foram considerados os resultados referentes a resolução espacial de 2 metros e buffer de 2 pixels, correspondendo na prática a vias de espessura de 8 metros. A Figura 56 exemplifica a linhas detectadas sobrepostas sobre as linhas de referência e seus respectivos os buffers.

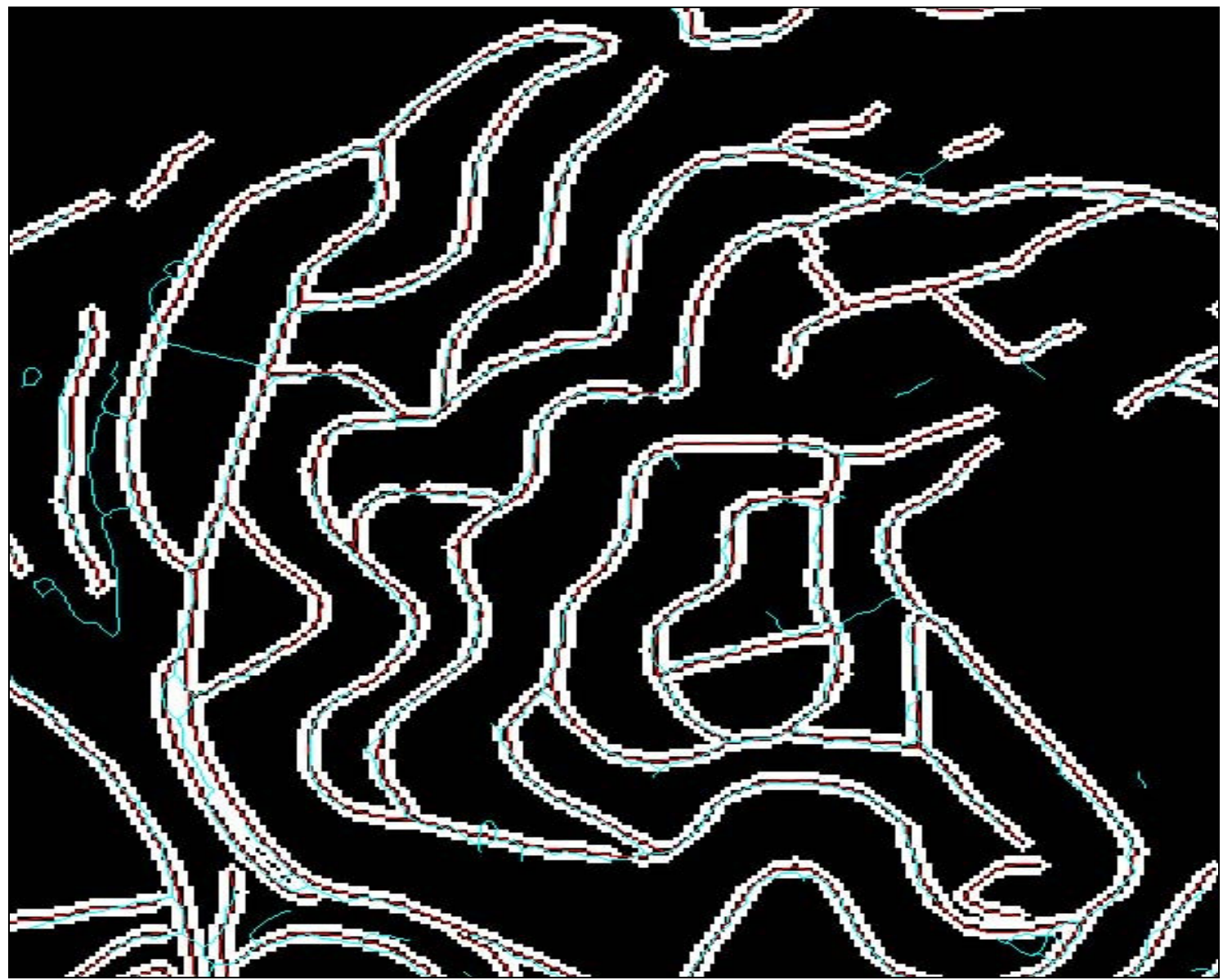

Figura 56 - Tela capturada do programa L-CAT ilustrando as linhas de referência (vermelho) e seus respectivos buffers, bem como as linhas detectadas das áreas classificadas (ciano).

Analisando os resultados obtidos da correspondência linear, e considerando a espessura média das vias como sendo de 8 metros (dada pela combinação resolução versus buffer), a metodologia obteve $64,66 \%$ de completeza. Em outras palavras, quase 65\% das vias presentes na imagem são representadas pela malha viária classificada. Vale ressaltar que ao considerar a média da espessura das vias com sendo de 8 metros, o que na 
prática caracteriza um cenário conservador como o que fora estabelecido, a precisão tende a diminuir e os erros a aumentarem.

Ainda, sobre o mesmo ponto de vista conservador, a precisão geral com que a malha viária foi classificada foi de $61,8 \%$. A estatística das lacunas, ou seja, das vias existentes na imagem e que não foram detectadas pela metodologia, mostra que a dimensão média das lacunas é de 21 metros, sendo que foram computadas em média 18 lacunas para cada quilômetro linear de via. 


\section{DISCUSSÃO}

São apresentados nesse capítulo os principais tópicos que influenciaram significativamente o desenvolvimento do trabalho, cuja discussão a respeito não caberia na estrutura natural do texto. Obedecendo ao propósito do trabalho, as diferenças entre pontos de vista e formas de interpretação das informações presentes nas imagens forçaram, em alumas vezes, a mudar prioridades quanto a tomada de decisões, desde a escolha do material a ser empregado como referência até a interpretação dos dados finais para o controle de qualidade.

O texto aqui apresentado envolve discussões sobre a metodologia desenvolvida e discussões sobre a particularidade do sistema viário detectado, em relação aos demais trabalhos de detecção de vias. São, também, apresentadas discussões sobre as formas utilizadas para analisar a acurácia da classificação e a respectiva comparação entre os seus resultados. Ao final, são apontadas algumas lacunas não cobertas pelo trabalho, para as quais são propostas sugestões para trabalhos futuros.

\subsection{A MALHA VIÁRIA REFERENCIAL}

Foi previsto inicialmente o emprego de uma base vetorial contendo os logradouros de forma que a exatidão da classificação pudesse ser atestada, como ocorre em trabalhos como Gerke e Busch (2005), Granzow (2005), Wessel e Wiedemann (2003), Wiedemann (2003), Zhang e Couloigner (2006) e Zhang, Murai e Baltsavias (1999). No entanto, ao organizar o material, recortando a área de estudo e efetuando transformações entre diferentes sistemas de coordenadas, pode-se observar a escassez de informações na base vetorial dos logradouros, oriunda do Projeto Cabuçu de Baixo, em especial nas regiões mais periféricas da área de estudo. 
Atribuiu-se a essa incompatibilidade de informações a grande diferença entre as datas, atual, e de compilação da carta original da base de logradouros. Também, a escassez de detalhes é atribuída à incompatibilidade da escala de observação aqui utilizada e à escala da carta origem dessa base vetorial.

Como solução, as referências viárias foram criteriosamente extraídas a partir das ortofotos. Essa opção forneceu extrema confiança quanto ao detalhamento das feições no terreno. Ademais, a diferença de tempo entre o vôo que deu origem as ortofotos e a imagem IKONOS utilizada é de aproximadamente 11 meses, sendo bem inferior que a diferença mencionada anteriormente.

O fato é que a adoção de um referencial como o aqui utilizado resulta em uma metodologia incompatível às demais relatadas na literatura. Por outro lado, deve ser considerado que todas as referências previamente mencionadas nesse item tratam de propostas metodológicas apoiadas em informações já existentes, como a malha viária atualizada da região de estudo. A realidade da maior parte das cidades brasileiras é diferente, onde a ausência de bases vetoriais atualizadas é mais freqüente do que se possa imaginar.

Alguns trabalhos como Seo e O'Hara (2004) optam pela coleta do referencial viária via rastreio dinâmico a partir de GPS, seguindo com um veículo sobre as vias que serão utilizadas para a análise da acurácia. Nesse sentido, a adoção de ortofotos ainda sim causaria menor impacto quanto a diferença de tempo. Um eventual rastreio dinâmico com GPS realizado no decorrer do presente trabalho geraria uma diferença entre datas (rastreio e imagens IKONOS) de pelo menos 36 meses. Outro fato bastante inconveniente para a adoção dessa metodologia de coleta seria a dificuldade (até mesmo a restrição) de acesso nas vias da área de estudo, pois como se sabe, a ocupação de grande parte dessa região é irregular.

Em se tratando de amostragem, em sensoriamento remoto, as visitas de campo normalmente utilizadas para a verificação da exatidão da classificação são pontuais. Assim como nos trabalhos propostos por Seo e O'Hara (2004), Wessel e Wiedemann (2003) e Wiedemann (2003), a coleta das 
vias referenciais desse trabalho produziu uma base contínua, o que eleva a confiabilidade da análise comparativa por descartar a inferência estatística, ou seja, as conclusões acerca da população não são tiradas usando informações de amostras.

\subsection{PARTICULARIDADE DA PESQUISA}

Em trabalhos como Bauer e Steinnocher (2001), Centeno et al(2003), Ehlers et al (2006), Fraumann e Wolf (2005), Gerke (2002), Gerke, Heipke e Straub, Hofmann (2001), Kressler, Kim e Steinnocher (2003), Nobrega et al (2006), Pinho (2005), Pinho, Feitosa e Kux (2005), Shackelford e Davis (2003) são relatados resultados expressivos quanto a precisão com que as classes de cobertura do solo urbano foram extraídas com o emprego da classificação orientada a objetos. Em geral, a exatidão chega a atingir em torno de $90 \%$.

A exatidão geral da classificação da malha viária apresentada nesse trabalho atingiu apenas 64,5\%, um resultado aquém dos demais, em se tratando de classificação orientada a objetos aplicada em área urbana.

Parte dessa significativa diferença pode ser atribuída à particularidade das características das vias presentes na área de estudo. Dessa forma, essa relativa diferença pode ser devido ao fato de que ruas em áreas periféricas, como a área de estudo em questão, têm larguras irregulares, os materiais dos pavimentos não são uniformes nem tem o mesmo tempo de uso, gerando texturas complexas. A alta complexidade dos objetos de interesse e dos objetos ao redor, presentes nessa área, dificulta até mesmo a discriminação visual dos mesmos.

Vale ressaltar que, através de análises visuais desenvolvidas imediatamente após a estimação dos erros de omissão e comissão, foi revelado que a maioria dos objetos não classificados correspondia a ruas sujas, trechos oclusos por árvores e/ou veículos (carros, caminhões e ônibus). 
Da mesma forma, para as áreas classificadas erroneamente, foi verificada a extrema semelhança espectral entre grande parte das edificações e as vias pavimentadas, ou seja, algumas edificações e outros elementos da cena construídos pelo homem foram confundidos com ruas.

Para que fosse possível a detecção das vias pavimentadas sem um comprometimento maior do erro de omissão, as regras de classificação passaram a englobar uma amplitude maior de parâmetros, o que fez aumentar o erro de comissão devido à similaridade espectral para com grande parte das edificações. Muitas dessas edificações apresentam-se agrupadas e com a ausência de espaços vazios entre as mesmas. Isso gera uma certa continuidade quando observadas do alto. Ainda, o padrão de cobertura utilizado pela maioria dessas edificações é concreto e, sabe-se que na prática, pela ausência da cobertura cerâmica, são utilizados revestimentos à base de asfalto (piche, manta asfáltica) como sendo uma solução eficiente e menos onerosa contra a umidade. Esse padrão de edificação e cobertura influencia fortemente a confusão espectral para com as vias, fato ainda não discutido em sensoriamento remoto.

Esse ponto de equilíbrio entre as restrições impostas pelos limiares nas regras e seu efeito em termos de erros de omissão e comissão não fora discutido nas bibliografias consultadas.

\subsection{ACURÁCIA GERAL}

Embora as análises visuais tenham fornecido bons indicadores da qualidade da detecção realizada, a quantificação da acurácia obtida pela metodologia foi baseada no cruzamento entre as áreas classificadas e as áreas de referência. Os valores então gerados foram empregados para que fossem determinados a acurácia geral do processo, ou seja, a percentagem da malha viária que efetivamente fora detectada pela metodologia, bem como os erros de omissão e comissão. 
Em números, a acurácia geral obtida pelo cruzamento dos planos de informação foi de $64,5 \%$. Em vista da heterogeneidade do cenário urbano da área de estudo, que reflete diretamente a não padronização geométrica e espectral das feições como as vias e as edificações, bem como em vista da complexa geometria das vias nas áreas mais periféricas, permite-se considerar $64,5 \%$ como um valor aceitável.

As estatísticas complementares, dadas pelos erros de comissão e omissão dão suporte aos eventuais questionamentos sobre a eficiência da metodologia. Apoiado na mesma analogia, o erro de omissão de $35,5 \%$ foi bastante significativo e aponta para a necessidade de aperfeiçoar as regras de classificação. A redução das vias omissas tende a aumentar a acurácia geral da detecção. No entanto a particularidade já mencionada da malha viária na área de estudo permitiu aceitar tal ordem de grandeza.

As áreas classificadas erroneamente como vias atingem $76,5 \%$ das áreas classificadas. Em outras palavras, $76,5 \%$ dos resultados da classificação correspondem a feições urbanas que não vias propriamente ditas, um valor consideravelmente alto. Entretanto, vale ressaltar que o poder de discriminação de uma imagem IKONOS para detectar uma via estreita passa a ser limitado. Com isso, bastam poucos pixels classificados erroneamente para que o erro de comissão aumente consideravelmente. Um exemplo claro disso é o caso da inclusão das calçadas como parte da via detectada.

Esse alto valor alavancou o questionamento sobre a viabilidade metodologia adotada. Ao considerar a aderência entre a malha viária detectada e as respectivas referências, pode-se notar que, embora os polígonos classificados cobrissem a área equivalente as vias, eles apresentavam, em geral, excessos de área. Isso fez com que os mesmos fossem afinados e as linhas resultantes fossem analisadas. De forma análoga o que foi verificado foi a alta aderência entre as linhas e as vias. Para quantificar essa aderência, como sugere a bibliografia, foi necessário computar a completeza e a precisão através da análise linear comparativa.

A ferramenta utilizada não permitiu que fossem geradas zonas de análises com 9 metros de largura, compatíveis com a largura média das vias na 
área de estudo. Os resultados foram obtidos para diferentes zonas, no entanto o foco foi para as zonas com 8 e 10 metros de espessura.

Uma interpolação simples entre as zonas de 8 e de 10 metros gerou os correspondentes valores para a zona de 9 metros (Tabela 9 ).

Tabela 9 - Interpolação da precisão para a zona de análise com largura de 9 metros.

\begin{tabular}{c|c|c|c}
\hline Parâmetro & 8 metros & 10 metros & $\begin{array}{c}9 \text { metros } \\
\text { (interpolado) }\end{array}$ \\
\hline precisão & $61.8 \%$ & $67,17 \%$ & $64,48 \%$ \\
\hline
\end{tabular}

Considerando a precisão como sendo o percentual das linhas corretamente extraídas, nota-se que o valor obtido reflete com extrema semelhança a acurácia geral da classificação obtida na primeira análise comparativa.

Também, vale considerar que as estatísticas das lacunas reflete o erro de comissão calculado. Em números, e considerando o cenário conservador da zona de análise de 8 metros, foram computadas em média 17,61 lacunas para cada $\mathrm{Km}$, bem como uma média de 20,88 metros por lacuna, o que corresponde a $368 \mathrm{~m}$ de lacuna para cada quilômetro de via (ou $36,8 \%$ ). Esse número esta próximo dos $35,5 \%$ referente ao erro de omissão relatado anteriormente.

\subsection{SUGESTÕES PARA TRABALHOS FUTUROS}

A conclusão desse trabalho não representa o fechamento absoluto da linha de raciocínio. Mesmo concluída, a metodologia apresenta certas deficiências que advêm principalmente da especificação do material utilizado e das dificuldades encontradas no desenvolvimento das regras e estratégias de classificação. 
Algumas sugestões relevantes para serem consideradas em trabalhos futuros são:

- Emprego da banda pancromática como base para a segmentação;

- Emprego de imagens QUICKBIRD ou imagens de sensores com configuração de bandas espectrais semelhante;

- Avaliação estatística da efetiva contribuição dos descritores envolvidos no processo de classificação;

- Aprimoramento das regras de classificação, em especial visando reduzir as lacunas e, respectivamente o erro de omissão.

- Desenvolvimento de processos complementares baseados em operadores morfológicos para, por exemplo, reconstruir as linhas ausentes nas lacunas;

- Emprego de modelo digital de superfície para auxiliar a identificação das vias e proporcionar maior separabilidade para com as demais feições; 


\section{CONCLUSÃO}

A hipótese levantada nesse trabalho foi a viabilidade da detecção da malha viária em áreas de ocupação urbana irregular a partir de imagens de alta resolução espacial empregando classificação de imagens orientada a objetos.

O desenvolvimento da metodologia para detecção da malha viária necessitou do conhecimento das características espectrais, geométricas e contextuais das feições presentes na área de estudo. $\mathrm{A}$ extrema heterogeneidade das feições urbanas, como forma e distribuição das ruas e das edificações, bem como a não uniformidade quanto ao padrão de pavimentação das vias e coberturas das edificações dificultou a obtenção de objetos homogêneos pela segmentação. A identificação das classes SOLO EXPOSTO e ÁREA IMPERMEABILIZADA, utilizando basicamente informações espectrais, possibilitou a detecção das vias pavimentadas e não pavimentadas, apoiadas pelas informações geométricas dos objetos.

Três formas de análise dos resultados foram apresentadas. A primeira tratou de uma avaliação qualitativa empregando a visualização tridimensional da malha viária detectada sobre as ortofotos de referência, onde se atestou a aderência do produto para com as vias reais. A segunda análise tratou da comparação entre a área ocupada pelas vias classificadas com a área real das vias. A acurácia da metodologia pôde então ser quantificada e atingiu $64,5 \%$. Também, foram quantificados os erros de omissão e comissão de $35,5 \%$ e $76,5 \%$, respectivamente. Os altos valores dos erros, em especial o erro de comissão alavancaram uma terceira forma de análise dos resultados, a análise de correspondência linear, que revelou precisão compatível à precisão quantificada na segunda análise. No entanto, a correspondência linear não demonstrou ser influenciada pela classificação excessiva das áreas e revelou que a metodologia apresenta resultados coerentes.

Mesmo em se tratando de condições extremas, foi verificado que cerca de $65 \%$ das vias presentes na área de estudo puderam ser detectadas. Isso revela um resultado inferior aos demais trabalhos que recorreram a 
classificação orientada a objetos. A enorme heterogeneidade das feições presentes no ambiente urbano da periferia, como presente na área de estudo, dificulta excessivamente a padronização de regras. Frente a isso, a acurácia obtida na detecção da malha viária indica sim que a metodologia apresenta um grande potencial.

Como primeiro trabalho do gênero desenvolvido, a metodologia de detecção da malha viária na periferia urbana não visou mapear [no sentido próprio da palavra] a área de estudo, mas sim prover meios de suprir a demanda por informações precisas e rápidas sobre a existência de vias que possam apoiar processos de gestão.

Como conseqüência, a metodologia de detecção da malha viária foi desenvolvida para que a mesma possa ser aplicada em outras áreas periféricas, desde que sejam disponibilizadas imagens de resolução espacial, espectral e radiométrica compatíveis às imagens IKONOS aqui empregadas. Com base nos resultados então obtidos, seu emprego pode ser entendido ao monitoramento do crescimento da malha viária, uma vez que o mesmo foi desenvolvido remotamente. 


\section{REFERÊNCIAS BIBLIOGRÁFICAS}

ALVAREZ, I. A. Qualidade do espaço verde urbano: uma proposta de índice de avaliação. 2004. 187 f. Tese (Doutorado) - Escola Superior de Agricultura Luiz de Queiroz, Universidade de São Paulo, Piracicaba, 2004.

ASPRS - AMERICAN SOCIETY FOR PHOTOGRAMMETRY AND REMOTE SENSING. Manual of photogrammetry. $5^{\text {th }}$ ed. Bethesda: American Society for Photogrammetry and Remote Sensing, 2004. $1151 \mathrm{p}$.

ANDRADE, A. F.; BOTELHO, M. F.; CENTENO, J. A. S. Classificação de imagens de alta resolução integrando variáveis espectrais e forma utilizando redes neurais artificiais. In: SIMPÓSIO BRASILEIRO DE SENSORIAMENTO REMOTO, 11., 2003, Belo Horizonte. Anais... Belo Horizonte: INPE, 2003. p. 265-272.

ANTUNES, A. F. B. Classificação de ambiente ciliar baseada em orientação a objeto em imagens de alta resolução espacial. 2003. $147 \mathrm{f}$. Tese (Doutorado) -. Universidade Federal do Paraná, Curitiba, 2003.

ANTUNES, A. F. B.; LINGNAU, C.; SILVA, J. C. Object oriented analysis and semantic network for high resolution image classification. In: SIMPÓSIO BRASILEIRO DE SENSORIAMENTO REMOTO, 11., 2003, Belo Horizonte. Anais... Belo Horizonte: INPE, 2003. p. 273-279.

APLIN, P. Comparison of simulated IKONOS and SPOT imagery for classifying urban areas. In: MESEV, V. Remotely sensed cities. London: Taylor \& Francis, 2003. p. 23-45.

BAATZ, M. et al. eCognition user guide. Munich, Germany: Deniniens Imaging $\mathrm{GmbH}$, 2004. Disponível em: <www.definiens-imaging.com/support>. Acesso em: 20 maio 2004.

BAATZ, M.; SCHÄPE, A. Multiresolution segmentation: na optimization for high quality multi-scale image segmentation. In: STROBL, J.; BLASCHKE, T.;

GRIESEBNER, G. Angewandt geographische informationsverarbeitung XII. Heidelberg: Wichmann Verlag, 2001. p. 12-13. Disponível em:

$<w w w . c a f . d l r . d e / c a f / a n w e n d u n g e n / p r o j e k t e / p r o j e k t e \_n u t z u n g / l a n d s a t / l a n d s a t \_p$ rojekte/Projekt\%20Hoffmann/lit/baatz_schaepe.pdf>. Acesso em: 25 mar. 2005. 
BALTSAVIAS, E. Object extraction and revision by image analysis using existing geodata and knowledge: current status and steps towards operational systems. ISPRS Journal of Photogrammetry and Remote Sensing, Amsterdam, n. 58, p. 129-151, 2004.

BALTSAVIAS E.; GRUEN, A. Resolution convergence: a comparison of aerial photos, LIDAR and IKONOS for monitoring. In: MESEV, V. Remotely sensed cities. London: Taylor \& Francis, 2003. p. 47-82.

BALTSAVIAS, E.; PATERAKI, M.; ZHANG, L. Radiometric and geometric evalutaion of ikonos geoimages and their use for $3 d$ building modelling. In: JOINT ISPRS WORKSHOP HIGH RESOLUTION MAPPING FROM SPACE, 2001, Hannover. Proceedings... Hannover: ISPRS, University of Hannover, 2001. p.15-35. 1 CD-ROM.

BANON, G. F.; BARREIRA, J. Bases morfologia matemática para análise de imagens binárias. Recife: UFPE, 1994. 230 p. (Escola de Computação, 9).

BARNSLEY, M. J.; STEEL, A. M.; BAAR, L. Determining urban land use through an analysis of the spatial composition of the buildings identified in LIDAR and multispectral image data. In: MESEV, V. Remotely sensed cities. London: Taylor \& Francis, 2003. p. 83-108.

BARROS, M. T. L. Gerenciamento integrado de bacias hidrográficas em áreas urbanas. São Paulo: EPUSP, 2004. 52 p. Disponível em: <www.phd.poli.usp.br/cabucu>. Acesso em: 20 out. 2004.

BARROS, M. T. L. et al. Plano de bacia urbana: relatório final. São Paulo: EPUSP; FUSP; FINEP; CNPq, 2005. Não publicado.

BENEDIKTSSON, J. A.; SWAIN, P. H.; ERSOY, O. K. Neural approaches versus statistical methods in classification of multisource remote sensing data. IEEE Transactions on Geoscience and Remote Sensing, New York, v. 28, n. 4, p. 540-552, 1990. 
BLASCHKE, T.; GLÄSSER, C.; LANG, S. Processamento de imagens num ambiente integrado SIG e sensoriamento remoto: tendências e consequências. In: ; KUX, H. Sensoriamento remoto e sig avançados: novos sistemas sensores: métodos inovadores. São Paulo: Oficina de Textos, 2005. p.11-18.

BLASCHKE, T.; STROBL, J. What's wrong with pixels? Some recent developments interfacing remote sensing and GIS. GIS Zeitschrift für Geoinformationssysteme, n. 6, p.12-17, 2001.

CABLK, M. E.; MINOR, T. B. Detecting and discriminating impervious cover with high-resolution IKONOS data using principal component analysis and morphologic operators. International Journal of Remote Sensing, London, v. 24, n. 23, p.4627-4645, 2003.

CENTENO, J. A. S.; ANTUNES, A. F. B.; TREVISAN, S.; CORREA, F. Mapeamento da áreas permeáveis usando uma metodologia orientada a regiões e imagens de alta resolução. Revista Brasileira de Cartografia, Rio de Janeiro, n. 55/1, p. 48-56, jul. 2003.

CONGALTON, R. G. Considerations and techniques for assessing the accuracy of remotely sensed data. In: IGARSS'89 CANADIAN SYMPOSIUM ON REMOTE SENSING, 12., 1989. Proceedings... Canada, 1989. v. 3, p. 18471850.

CRÓSTA, A. P. Processamento digital de imagens de sensoriamento remoto. Campinas: IG/UNICAMP, 1992. $170 \mathrm{p}$.

DE KOK, R.; WEVER, T.; FOCKELMANN, R. Analysis of urban structure and development applying procedures for mapping of large area data. In:

CARSTENS, J. (Ed.). Remote sensing of urban areas. Regemburg, Germany, 2003. p. 41-46.

DELL'ACQUA, F.; GAMBA, P. Urban remote sensing and data fusion: a perfect wedding. In: INTERNATIONAL SYSMPOSIUM ON REMOTE SENSING OF URBAN AREAS, 3., 2002, Istambul. Proceedings... Istambul, 2002. v. 1, p. 293-301. 
DOWMAN, I. High resolution mapping from space: status and issues. In: JOINT ISPRS WORKSHOP HIGH RESOLUTION MAPPING FROM SPACE, 2001, Hannover. Proceedings... Hanover: ISPRS, University of Hannover, 2001. p. 47-54. 1 CD-ROM.

DUDA, R. O.; HART. P. E. Pattern classification and scene analysis. New York: John Wiley, 1973. $482 \mathrm{p}$.

EHLERS, M. et al. Decision based data fusion techniques for the analysis of settlements areas from multisensor satellite data. In: ASPRS 2006 ANNUAL CONFERENCE, 2006, Reno, Nevada. Proceedings... Reno, Nevada, 2006.

FRAUMAN, E.; WOLF, E. Segmentation of very high spatial resolution satellite images in urban areas for segments-based classification. In: INTERNATIONAL SYMPOSIUM REMOTE SENSING AND DATA FUSION OVER URBAN AREAS, 3., 2005, Tempe, AZ, USA. Proceedings... Tempe, AZ, USA, 2005. Disponível em:

<http://www.isprs.org/commission8/workshop_urban/frauman.pdf> Acesso em: 10 jan. 2006.

\section{FUNCATE - FUNDACCAO DE CIÊNCIA, APLICACÕ̃ES E TECNOLOGIAS} ESPACIAIS. Instituto Geológico da Secretaria do Meio Ambiente do Estado de São Paulo. Relatório descritivo dos produtos de sensoriamento remoto. São José dos Campos: FUNCATE, 2004. 80 p.

GERKE, M. Scene analysis in urban areas using a knowledge-based interpretation system. In: PHOTOGRAMMETRIC COMPUTER VISION'02, 2002, Grass, Austria. Proceedings... Grass, Austria, 2002. v. 34, part 3A, 3B, p. 63-66.

GERKE, M.; HEIPKE, C.; STRAUB, B-M. Build extraction from aerial imagery using a generic scene model and invariant geometric moments. In: ISPRS JOINT WORKSHOP ON REMOTE SENSING AND DATA FUSION OVER URBAN AREAS, 2001, Pavia, Rome. Proceedings... Pavia, Rome: University of Pavia, 2001. Disponível em: <http://www.ipi.uni-

hannover.de/html/publikationen/2001/gerke/gerke_heipke_straub_ieee_isprs.ht m> Acesso em 20 Abr. 2003.

GUENNADI, G.; YERACH D. Geographic information system data for supporting feature extraction from high resolution aerial and satellite images. Journal of Surveying Engineering, Reston, Virginia, v. 129, p. 158-164, Nov. 2003. 
GONZALES, R. C.; WOODS, R. E. Digital image processing. $3^{\text {rd }}$ ed. Massachusetts: Addison-Wesley, 1993. 716 p.

GONZALES, R. C.; WOODS, R. E.; EDDINS, S. L. Digital image processing using MATLAB. New Jersey: Prentice Hall, 2004. 609 p.

GRUEN, A. Potential and limitations of Highresolution Satellite Imagery. In: ASIAN CONFERENCE ON REMOTE SENSING, 21., 2000, Taipei, Taiwan. Proceedings... Taipei, Taiwan, 2000. $14 \mathrm{p}$.

GUPTA, V. New satellite images for sale: the opportunities and risks ahead. Center for Security and Technology Studies Lawrence Livermore National Laboratory, 2002. Disponível em:

<http://www.llnl.gov/csts/publications/gupta/contents.html>. Acesso em: 12 mai. 2005.

GWYNN, D. W. An application of object-oriented change detection to urbanizing areas. In: ASPRS ANNUAL CONFERENCE, 2005, Baltimore. Proceedings... Baltimore, 2005.

HEIPKE, C.; PAKZAD, K.; WILLRICH, F. Integration of geodata and imagery for automatic refinement and update of spatial databases. ISPRS Journal of Photogrammetry and Remote Sensing, Amsterdam, v. 58, p.127-128, 2004.

HUANG, H.; BINGFANG, W.; JINLONG, F. Analysis to the relationship of classification accuracy, segmentation scale and image resolution. In: INTERNATIONAL GEOSCIENCE AND REMOTE SENSING SYMPOSIUM IGARSS/IEEE, 2003, Toulouse, France. Proceedings... Toulouse, France, 2003. Disponível em: <www.definiens-imaging.com>. Acesso em: 22 jul. 2004.

INPE - INSTITUTO NACIONAL DE PESQUISAS ESPACIAIS. SPRING 4.1.1: sistema de ajuda on-line do spring - manual do usuário. São José dos Campos: INPE, 2005. Disponível em: < http://www.dpi.inpe.br/spring/portugues/manuais.html> acesso em 22 jul. 2003.

JACOBSEN, K. Use of very high resolution satellite imagery. In: POLNISCHE GESELLSCHAFT FÜR PHOTOGRAMMETRIE FERNERKUNDUNG UND GIS, 2004, Warschau. Proceedings... Warschau, 2004. Disponível em:

$<$ http://www.ipi.uni-

hannover.de/html/publikationen/2005/paper/jac_warschau_05.pdf> Acesso em: 07 set. 2004. 
JACOBSEN, K. Mapping with ikonos images. In: EARSeL ISPRS SYMPOSIUM, 2002- Geoinformation for European-wide Intergration, Prague. Proceedings... Prague, Jun. 2002. p. 149-156.

JANNUZZI, P. M.; JANNUZZI, N. Crescimento urbano, saldos migratórios e atratividade residencial dos distritos da cidade de São Paulo: 1980 - 2000.

Revista Brasileira de Estudos Urbanos e Regionais, Recife, v. 4, n. 1/2, p. 107-127, Maio/Nov. 2002.

JENSEN, J. R. Remote sensing of the environment: an earth resource perspective. New Jersey: Prentice Hall, 2000. 554 p.

JENSEN, J. R. Introductory digital image processing: a remote sensing perspective. New Jersey: Prentice Hall, 1986. 379 p.

KOHN, A. F. Reconhecimento de padrões: uma abordagem estatística. São Paulo: EDUSP, 1998. 205 p.

KOYUNCU, $\mathrm{H}$. Evaluation of high resolution IKONOS satellite imagery for urban applications. In: INTERNATIONAL SYMPOSIUM OF REMOTE SENSING OF URBAN AREAS, 3., 2002, Istanbul, Turkey. Proceedings... Istanbul, Turkey, 2002.

KRESSLER, F. P.; KIM, Y. S.; STEINNOCHER, K. T. Object-oriented land cover classification of panchromatic KOMPSAT-1 and SPOT-5 data. In: INTERNATIONAL GEOSCIENCE AND REMOTE SENSING SYMPOSIUM IGARSS/IEEE, 2003, Toulouse, France. Proceedings... Toulouse, France, 2003. Disponível em: <www.definiens-imaging.com>. Acesso em: 06 jun. 2005.

LABA, M et al. Conventional and fuzzy accuracy assessment of New York gap analysis project land cover map. In Remote Sensing of Environment. 81 p.443-455. 2002.

LILLESAND, T. M.; KIEFER, K. W.; CHIPMAN, J. W. Remote sensing and image interpretation. $5^{\text {th }}$ ed. New York: Wiley, c2004. $763 \mathrm{p}$. 
LEUKERT, K. Utilização de dados de SIG para a obtenção de objetos. In: BLASCHKE, T.; KUX, H. Sensoriamento remoto e sig avançados: novos sistemas sensores, métodos inovadores. São Paulo: Oficina de Textos, 2005. p. $140-146$.

MCANDREW, A. Introduction to digital image processing with MATLAB. Boston: Course Technology, 2004. 509 p.

MENESES, P. R.; MADEIRA NETTO, J. S. Fundamentos de radiometria óptica espectral. In: Brasília, DF: Ed. Unb, 2001. p. 15-40. MOHAM, B. K.; KADAM, S. U.; RAO, E. P. Segmentation of high resoltion imagery. GIS@Development Magazine, v. 7, n. 11, p. 35-38, Nov. 2003.

MOIK, J. G. Digital processing of remotely sensed images. Washington DC, NASA Scientific and Technical Information Services, 1980. 330 p.

MOREIRA, M. A. Fundamentos do sensoriamento remoto e metodologias de aplicação. São José dos Campos: INPE, 2001. 205 p.

MUELLER, M.; SEAL, K; KAUFMANN, H. Discrimination between roofing material and streets within urban areas based on hyperspectral, shape and context information. In: GRSS/ISPRS JOINT WORKSHOP ON DATA FUSION AND REMOTE SENSING OVER URBAN AREAS, 2., 2003, Berlin.

Proceedings... Berlin, 2003. p. 196-200.

MYINT, S. W. The use of wavelets for feature extraction of cities from sensor images. In: MESEV, V. Remotely sensed cities. London: Taylor \& Francis, 2003. p.109-134.

NEUBERT, M.; MEINEL, G. Análise de dados do satélite IKONOS baseada em segmentação - utilização do software de análise de dados eCognition para diferentes áreas-testes. In: BLASCHKE, T.; KUX, H. Sensoriamento remoto e sig avançados: novos sistemas sensores, métodos inovadores. São Paulo: Oficina de Textos, 2005. p. 115-124. 
NOBREGA, R. A. A.; O'HARA, C. G.; QUINTANILHA, J. A. Detecting roads in informal settlements surrounding São Paulo city by using object-based classification. In: INTERNATIONAL CONFERENCE ON OBJECT-BASED IMABE ANALYSIS, 1., 2006, Salzburg. Proceedings... Salzburg: Salzburg University, 2006. v. 36, part. 4/C42. Disponível em:

<http://www.commission4.isprs.org/obia06/Papers/16_Automated\%20classificat ion\%20IC\%2011\%20-

\%20Settlements\%20\&\%20Infrastructure/OBIA2006_Nobrega_OHara_Quintanil ha.pdf> Acesso em 10 jul. 2006.

NOBREGA, R. A. A. et al. Extracting and classifying bare soil erosion risk areas in a urban basin using object-based technologies, high resolution imagery and elevation data. In: GEOGRAPHIC INFORMATION SYSTEM AND WATER RESOURCES IV, AWRA SPRING SPECIALTY CONFERENCE, 2006, Houston, Texas. Proceedings... Houston: American Water Research Association, 2006. Disponível em: <http://www.definiens.com/pdf/publications/AWRA_2006.pdf>. Acesso em: 04 dez. 2006.

NOBREGA, R. A. A.; QUINTANILHA, J. A.; BARROS, M. T. L. Emprego de técnicas digitais para a concepção da base cartográfica precisa da Bacia Hidrográfica do Rio Cabuçu de Baixo. Rbrh: revista brasileira de recursos hídricos, São Paulo, 2005. No prelo.

NOVO, E. L. M. Sensoriamento remoto: princípios e aplicações. 2. ed. São Paulo: Edgard Blücher, 1992. 328 p.

O'HARA, C. Managing dynamic data: change detection and feature extraction methods support census bureau map updates. Earth Image Journal, v. 2, n. 2, p. $40-43,2005$.

PEREIRA CABRAL, B. J. Utilização de técnicas de segmentação e correlação de Spearman em imagens TM para o estudo da concentração de sedimentos em suspensão no reservatório de Barra Bonita - São Paulo - Brasil. Revista Internacional de Ciencia y Tecnología de la Información Geográfica, n. 3, p. 235-267, 2003.

PINHO, C. M. D. Análise orientada a objetos de imagens de satélite de alta resolução espacial aplicada à classificação de cobertura do solo no espaço intra-urnbano: o caso de São José dos Campos - SP. 2005. 179 f. Dissertação (Mestrado) - Instituto Nacional de Pesquisas Espaciais, São José do Campos, 2005. 
PINHO, C. M. D.; FEITOSA, F. F.; KUX, H. J. H. Classificação automática de cobertura do solo urbano em imagens IKONOS: comparação entre a abordagem pixel-a-pixel e orientada a objetos. In: SIMPÓSIO BRASILEIRO DE SENSORIAMENTO REMOTO, 12., 2005, Goiânia. Anais... São José dos Campos: INPE, 2005. p. 4217-4224.

PINILLA, C. Elementos de teledetectión. Madrid: Ed.Ra-Ma, 1995. 313 p.

QUINTANILHA, J. A.; SILVA, O. F. Identification of uban objects through IKONOS images. In: SIMPÓSIO BRASILEIRO DE SENSORIAMENTO REMOTO, 12., 2005, Goiânia. Anais... São José dos Campos: INPE, 2005. p. 4265-4268.

REES, G. The remote sensing data book. Cambridge; New York: Cambridge University Press, c1999. xii, 262 p.

REPAKA, S. R.; TRUAX, D. D.; KOLSTAD, E.; O'HARA, C. G. Comparing spectral and object based aproaches for classification and transportation feature extraction from high resolution multispectral imagery. In: ASPRS ANNUAL CONFERENCE, 2004, Denver, USA. Proceedings... Denver, USA, 2004.

SANTOS, M. A urbanização brasileira. 5. ed. São Paulo: EDUSP, 2001. 174 p.

SCHIEWE, J.; TUFTE, L. O potencial de procedimentos baseados em regiões para a avaliação integrada de dados de SIG e sensoriamento remoto. In: BLASCHKE, T.; KUX, H. Sensoriamento remoto e sig avançados: novos sistemas sensores, métodos inovadores. São Paulo: Oficina de Textos, 2005. p. 51-60.

SCHOWENGERDT, R. A. Remote sensing models and methods for image processing. $2^{\text {nd }}$ ed. San Diego: Academic Press, 1997. 525 p.

SCHOWENGERDT, R. A. Techniques for image processing and classification in remote sensing. New York: Academic Press, 1983. xv, 249 p. 
SEO, S.; O'HARA, C. G. A toolkit for quantifying linear feature extraction performance. In: ASPRS ANNUAL CONFERENCE, 2004, Denver, USA. Proceedings... Denver, USA, 2004.

SHACKELFORD, A. K.; DAVIS, C. H. A combined fuzzy pixel-based and objectbased approach for classification of high resolution multispectral data over urban areas. IEEE Transactions on Geoscience and Remote Sensing, New York, v. 41, n. 10, p. 2354-2363, Oct. 2003.

SIMÕES, A. S. Segmentação de imagens por classificação de cores: uma abordagem neural. 2000. 132 f. Dissertação (Mestrado) - Escola Politécnica, Universidade de São Paulo, São Paulo, 2000.

TOUNTIN, T.; CHENG, P. Demystification of IKONOS. Earth Observation, Magazine, Frederick, MD, v. 9, n.7, p.17-21, 2000. Disponível em: $<$ www.eomonline.com/Common/Archives/July00/toutin.htm>. Acesso em: 07 set. 2002.

TSO, B.; MATHER, P. M. Classification methods for remotely sensed data. London: Taylor \& Francis, 2001. 332 p.

VIJAYARAJ, V.; O'HARA, C. G.; YOUNAN, H. H. Utilizing multi-resolution image data vs. pansharpened image data for change detection. ASPRS ANNUAL CONFERENCE 2005, Baltimore. Proceedings...Baltimore: American Society for Photogrammetry and Remote Sensing Conference, 2005. 1 CDRom.

VINCENT, L. Morphological grayscale reconstruction in imageanalysis: applications and affieient algorithms. IEEE Transactions on Image Processing, New York, v. 2, n. 2, p. 176-201, Apr. 1993.

WESSEL, B.; WIEDEMANN, C. Analysis of automatic road extraction results from airborne SAR imagery. In: ISPRS WORKSHOP PHOTOGRAMMETRY AND REMOTE SENSING, 2003, Munich, Germany. Proceedings... Munich, Germany, v.34, part 3/W8, 2003. p. 105-110.

WIELDEMANN, C. External evaluation of road network. In: ISPRS WORKSHOP PHOTOGRAMMETRY AND REMOTE SENSING, 2003, Munich, Germany. Proceedings... Munich, Germany, v.34, part 3/W8, 2003. p. 93-98. 
WOODCOK, C. E.; STRAHLER, A. K. The factor of scale in remote sensing. Remote Sensing of Enviroment, New York, n. 21, p. 311-332, 1987.

ZHANG, Q.; COULOIGNER, I. Automatic road network extraction from high resolution multi-spectral imagery. In: ASPRS 2006 ANNUAL CONFERENCE, 2006, Reno, Nevada. Proceedings... Reno, Nevada, 2006.

ZHANG, C.; MURAI, S.; BALTSAVIAS, E. Road detection by using mathematical morphology. In: INTERNATIONAL WORKSHOP ON 3D GEOSPATIAL DATA PRODUCTION: MEETING APPLICATION REQUIREMENTS, 1999, Paris. Proceedings... Paris, 1999. p. 185-200. 


\section{REFERÊNCIAS CONSULTADAS}

BAUER, T.; STEINNOCHER, K. Per-parcel land useclassification in urban areas applying a rule-based technique. GeoBIT/GIS, n. 6, p. 24-27, Jun. 2001.

BENZ, U. et al. Multi-resolution, object-oriented fuzzy analysis of remote sensing data for GIS-ready information. ISPRS Journal of Photogrammetry and Remote Sensing, Amsterdam, n. 58, p. 239-258, 2004.

BRUZZONE, L.; PRIETO, D. F. Automatic analysis of the difference image for unsupervised change detection. IEEE Transaction on Geoscience and Remote Sensing, New York, v. 38, n. 3, p.1171-1181, 2000.

CÁMARA, M. A. U.; LÓPEZ, F. J. A. Generalización del casco urbano de la Ciudad de Jaén mediante morfologia matemática. Mappin: revista internacional de ciências de la tierra, n. 58, p. 20-24, Nov. 1999. Disponível em:

<http://www.mappinginteractivo.com/plantilla-ante.asp?id_articulo=690>. Acesso em: 25 out. 2006.

DOUGLAS, I. Human settlements. In: MEYER, W. B. (Ed.). Changes in land use and land cover: a global perspective. Cambridge: Cambridge University Press, 1994. cap. 7, p. 149-169.

GERKE, M.; BUSCH, A. Verification of a digital road database using IKONOS imagery. In: ISPRS HANNOVER WORKSHOP 2005: HIGH-RESOLUTION EARTH IMAGING FOR GEOSPATIAL INFORMATION, 2005, Hannover. Proceedings... Hannover, 2005. v. 36, part.1/w3. Disponível em: <www.ipi.unihannover.de>. Acesso em: 15 fev. 2006.

GRANZOW, E. Automatic feature recognition and extraction from remote sensing imagery. In: CENTERLINE EXTRACTION AND MAINTENANCE (CLEM2001), 2001, Santa Barbara. Proceedings... Santa Barbara: U.S. Department of Transportation; National Consortia on Remote Sensing in Transportation, 2001. v. 5. p.

HEROLD, M. Remote sensing and spatial metrics: a new approach for the description of structures and changes in urban areas. Enviroment and Planning A, London, v. 34, n. 8, p.1443-1459, 2002. 
HELLER, J.; PAKZAD, K. Adaption of object models for road extraction in images of different resolution. In: INTERNATIONAL SYMPOSIUM REMOTE SENSING AND DATA FUSION OVER URBAN AREAS, 3., 2005, Tempe, Arizona. Proceedings... Tempe, Arizona, 2005. 6 p. v. 36, part. 8/W27. Disponível em: <www.ipi.uni-hannover.de>. Acesso em: 21 maio 2005.

HOFMANN, P. Detecting informal settlements from IKONOS image data using methods of object oriented image analysis: an example from Cape Town South Africa. In: JURGENS, C. (Ed.). Remote sensing of urban areas. Regenburg, Regensburger Geographische Schriften, 2001. p. 107-118.

HOFMANN, P.; STROBL, J.; BLASCHKE, T. KUX, H. Detecting informal settlements from QUICKBIRD data in Rio de Janeiro using an object-based aproach. In: INTERNATIONAL CONFERENCE ON OBJECT-BASED IMABE ANALYSIS, 1., 2006, Salzburg. Proceedings... Salzburg: Salzburg University, 2006. v. 36, part. 4/C42. Disponível em:

<http://www.commission4.isprs.org/obia06/Papers/05_Automated\%20classificat ion\%20Urban/OBIA2006_Hofmann_et_al.pdf> Acesso em 10 jul. 2006.

HUANG, J.; KUMAR, S. R.; ZABIH, R. An automatic hierarchical image classification scheme. 1998. Disponível em:

<http://www.acm.org/sigs/sigmm/MM98/eletronic_proceedings/huang/>. Acesso em: 20 jul. 2006.

KARANJA, F. N. Use of knowledge based systems for the detection and monitoring of unplanned developments. 2002. $107 \mathrm{f}$. Tese (Doutorado) Institut für Photogrammetrie und Geolnformation, Universität Hannover, Hannover, 2002.

MASSER, I. Managing our urban future: the role of remote sensing and geographic information systems. Habitat International, Oxford, n. 25, p. 503512, 2001.

NOBREGA, R. A. A.; O'HARA, C. G.; QUINTANILHA, J. A. Preliminary results of road detection in informal settlements using object-oriented thechnology and IKONOS data. In: ANNUAL GRADUATE STUDENT ASSOCIATION OF MISSISSIPPI STATE UNIVERSITY, 4., 2006, Mississippi State. Proceedings... Mississippi, 2006. Disponível em:

<http://www.gri.msstate.edu/about/news/2006/support/poster_GSA2006_Nobre ga.pdf>. Acesso em: 21 nov. 2006. 
OHATA, A. T. Aplicação de técnicas de classificação para detecção e mensuração da expansão urbana da região metropolitana de São Paulo entre 1991 e 2002. 2004. 97 f. Dissertação (Mestrado) - Escola Politécnica, Universidade de São Paulo, São Paulo, 2004.

PISANI, M. A. J. Áreas de risco associado ao escorregamento para a ocupação urbana: detecção e monitoramento com o auxílio de dados de sensoriamento remoto. 1998. 188 f. Tese (Doutorado) - Escola Politécnica, Universidade de São Paulo, São Paulo, 1998.

QUINTANILHA, J. A. Erros em bases de dados espaciais para uso em sistemas de informação geográfica. 1996. $236 \mathrm{f}$. Tese (Doutorado) - Escola Politécnica, Universidade de São Paulo, São Paulo, 1996.

QUINTANILHA, J. A.; FREITAS, M. A. R. Revisão das técnicas de classificação de imagens de sensoriamento remoto. In: SIMPÓSIO DE COMPUTAÇÃO GRÁFICA À ARQUITETURA, ENGENHARIA E ÁREAS AFINS, 2., 1994, Salvador. Anais... Salvador: UFBA, 1994. p. 125-128.

SMALL, C. High spatial resolution spectral mixture analysis of urban reflectance. Remote Sensing of Environment, New York, n. 88, p.170-186, 2003.

STRAHLER, A.; WOODCOK, C. E.; SMITH, J. On the nature of models in remote sensing. Remote Sensing of Enviroment, New York, n. 20, p. 121$139,1986$.

SOH, L.-K.; TSATSOULIS, C. Segmentation of satellite imagery of natural scenes using data mining. IEEE Transactions on Geoscience and Remote Sensing, New York, v. 37, n. 2, p. 1086-99, Mar. 1999.

STRAUB, B. M.; HEIPKE, C. Automatic extraction of trees for 3D-city models from images and height data. In: AUTOMATIC EXTRACTION OF MAN-MADE OBJECTS FROM AERIAL AND SPACE IMAGES, 2001, Birkhäuser.

Proceedings... Birkhäuser, 2001. v. 3. p. 267-277.

TEIXEIRA, A. L. A.; CHRISTOFOLETTI, A. Sistema de informaçào geográfica: dicionário ilustrado. São Paulo: Hucitec, 1997. 244 p. 
ÜNSALAN, C.; BOYER, K. L. Classifying land development in high resolution panchromatic satellite images using straight-line statistics. IEEE Transactions on Geoscience and Remote Sensing, New York, v. 42, n. 4, p.907-919, 2004. 
